Milton Fernando Lamanauskas

\title{
A JURISPRUDÊNCIA ELEITORAL E SEUS REFLEXOS NO ESTADO DEMOCRÁTICO DE DIREITO
}

\author{
Dissertação de Mestrado \\ Orientadora: Prof ${ }^{a}$. Dra. Fernanda Dias Menezes de Almeida
}

FACULDADE DE DIREITO DA UNIVERSIDADE DE SÃO PAULO

SÃO PAULO

2009 
Milton Fernando Lamanauskas

\section{A JURISPRUDÊNCIA ELEITORAL E SEUS REFLEXOS NO ESTADO DEMOCRÁTICO DE DIREITO}

Dissertação apresentada para a obtenção do título de Mestre pelo Departamento de Direito do Estado da Faculdade de Direito da Universidade de São Paulo.

Orientadora: Prof ${ }^{a}$. Dra. Fernanda Dias Menezes de Almeida

FACULDADE DE DIREITO DA UNIVERSIDADE DE SÃO PAULO

SÃO PAULO

2009 
Aos meus pais, com amor. A Regiani e Felipe, meus amores. 


\section{Agradecimentos}

Agradeço imensamente à Prof ${ }^{\mathrm{a}}$. Fernanda Dias Menezes de Almeida, não só pela orientação para esse estudo, mas pelo exemplo de retidão, integridade e perseverança que nos anima a sempre seguir em frente.

Agradeço aos precisos amigos Fabio Ribeiro dos Santos e Christiane Boulos, que além de companheiros para toda a vida, não se cansam de compartilhar, com paciência e serenidade seus conhecimentos.

Agradeço aos queridos amigos Fernando Dias Menezes de Almeida e Telma Freitas Fontes, orientadores e incentivadores da vida acadêmica e conselheiros da vida profissional.

Agradeço a José Luiz Ricca a toda sua compreensão de um verdadeiro pai profissional, cujo caráter, honestidade e profissionalismo ensinaram-me a desviar das armadilhas da vida.

Agradeço aos companheiros da Secretaria de Desenvolvimento do Estado de São Paulo, pelo apoio e cobertura durante toda minha ausência.

Agradeço a Paulo Cezar da Silva pela disposição e habilidade em encontrar decisões preciosas para esse trabalho.

A todos, meu eterno agradecimento.

A meus pais, companheiros destas e de outras vidas, a quem tudo devo, todo meu agradecimento e amor, que são muito pouco por tudo que fizeram por mim até hoje.

A Regiani, pelo amor e pelo meu presente mais valioso, o Felipe, que nos seus sete meses de existência me fez companhia nas longas noites de escrita. 


\section{SUMÁRIO}

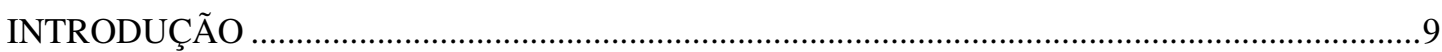

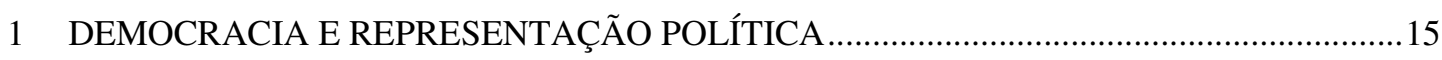

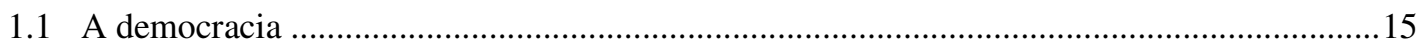

1.1.1 As diferentes formas históricas assumidas pela democracia .............................................16

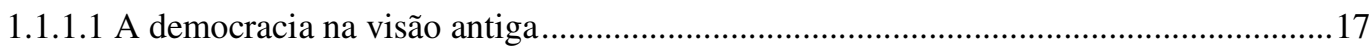

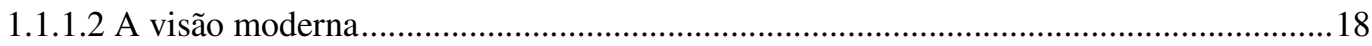

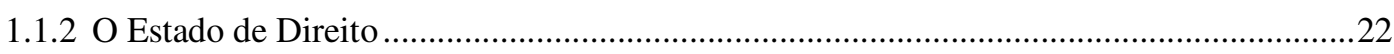

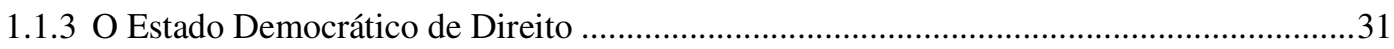

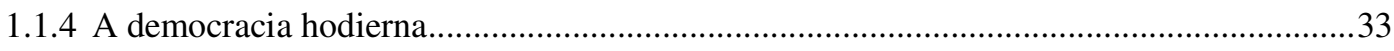

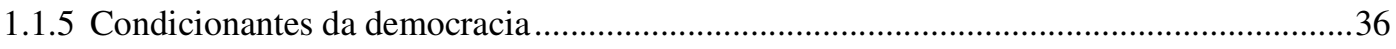

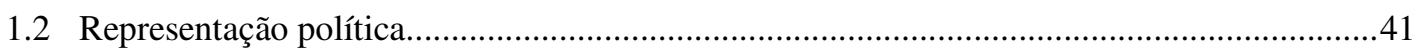

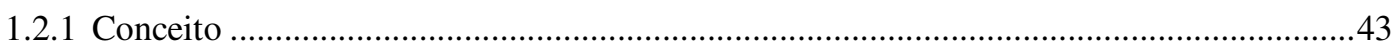

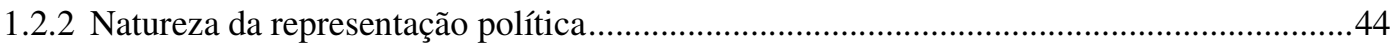

1.2.2.1 O Parlamento e a representação política..........................................................................47

1.2.2.2 Eleições e representação política................................................................................51

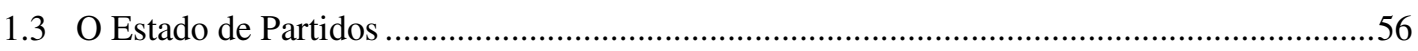

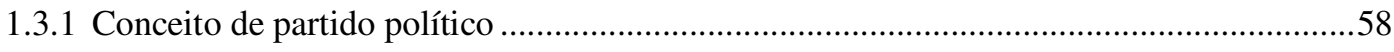

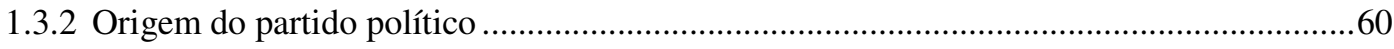

1.3.3 Da democracia representativa à democracia pelos partidos ............................................61

2 A RECENTE JURISPRUDÊNCIA ELEITORIAL E A ATUAÇÃO POLÊMICA DAS

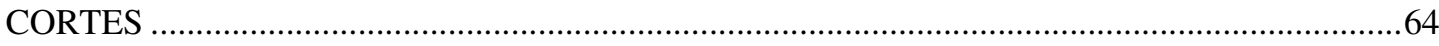

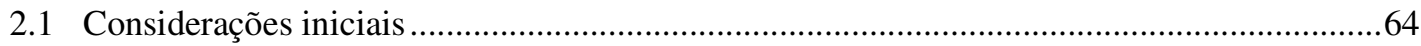

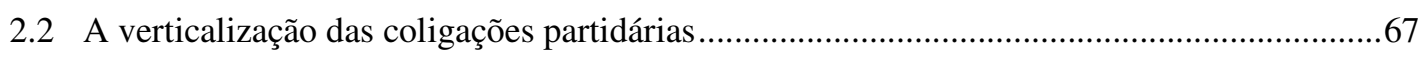

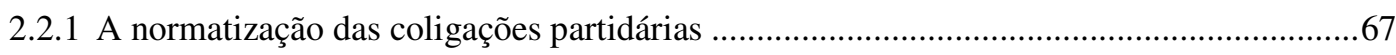

2.2.2 Resoluções N. 20.121 e N. 20.126 do TSE - A interpretação inicial sobre o instituto das

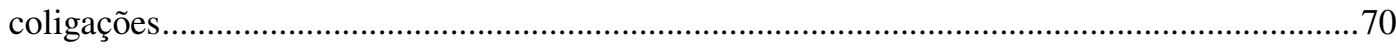


2.2.3 Resolução N. 21.002 do TSE - A instituição da verticalização via regulamento .72

2.2.4 Ilegalidade e inconstitucionalidade do regulamento do TSE ...........................................77

2.2.4.1 ADI N. 2.626 e ADI N. 2.628 - O questionamento da atividade normativa do TSE 79

2.2.5 Resolução N. 21.474 do TSE - Municípios excluídos da verticalização .............................82

2.2.6 Emenda Constitucional N. 52/06 - O Congresso reverte a decisão judicial .......................83

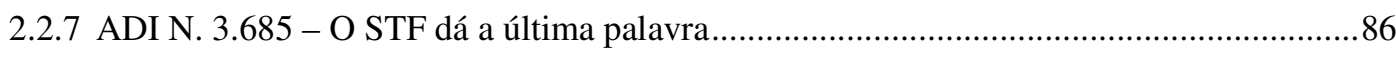

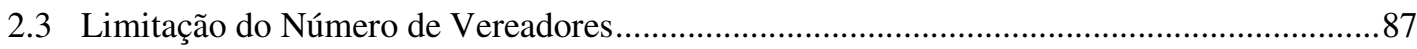

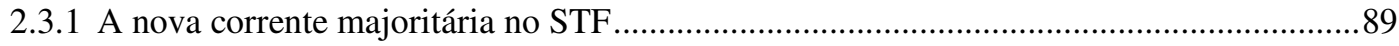

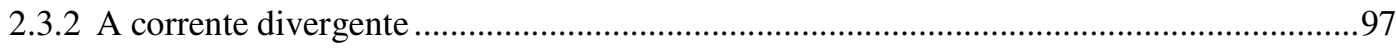

2.3.3 Distorção da representação política....................................................................................99

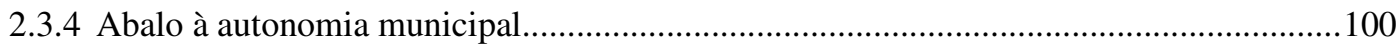

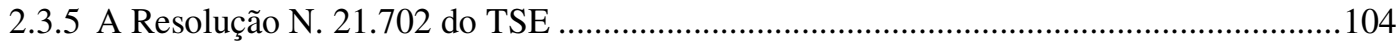

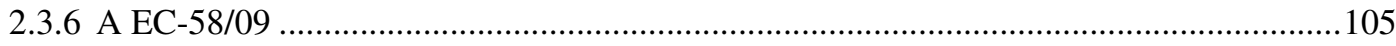

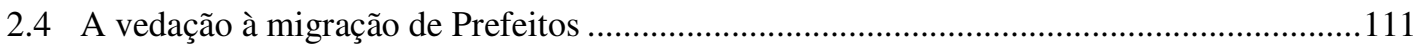

2.4.1 Histórico das decisões do TSE acerca das eleições municipais .......................................112

2.4.2 A recente decisão do TSE - Fim dos "Prefeitos itinerantes" ...........................................116

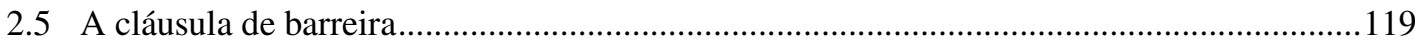

2.5.1 As consequências de eventual aplicação da cláusula de barreira às eleições ocorridas em

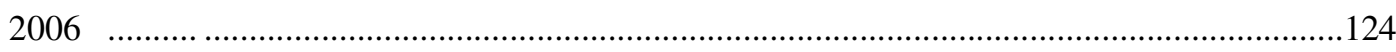

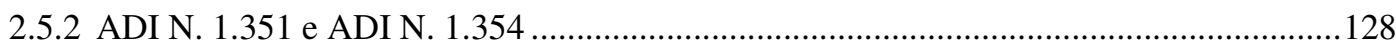

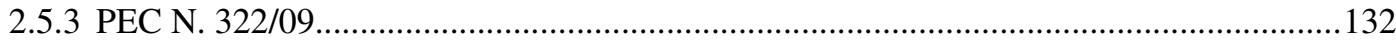

2.5.4 Nanicos ou oligarquias? As reais mazelas do sistema partidário .....................................133

2.6 A atividade interpretativa e normativa em matéria eleitoral ................................................ 137

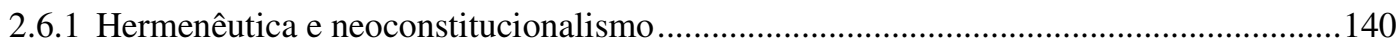

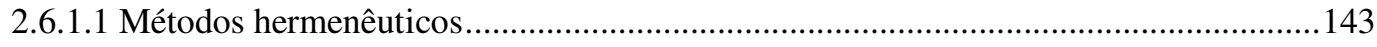

2.6.2 Os limites da interpretação constitucional e do poder normativo dos Tribunais...............146

2.6.3 A atividade hermenêutica e normativa na recente jurisprudência eleitoral .......................153

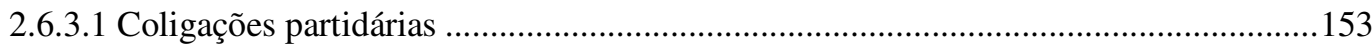


2.6.3.2 Limitação das vagas nas Câmaras Municipais ............................................................155

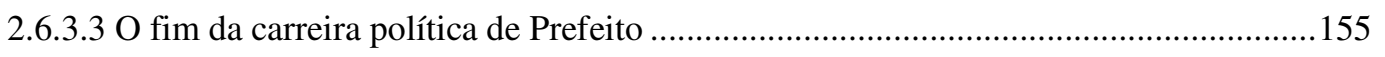

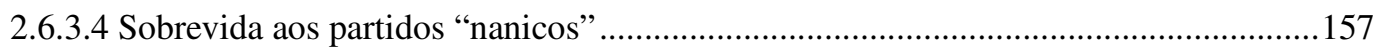

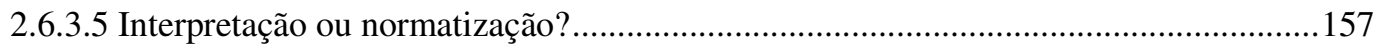

3 A JURISPRUDÊNCIA SOBRE A FIDELIDADE PARTIDÁRIA …........................................ 160

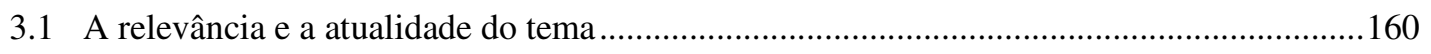

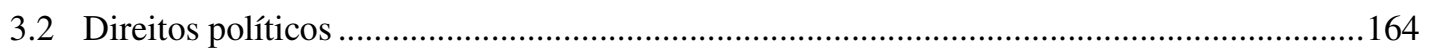

3.3 Decisões precedentes do STF sobre a fidelidade partidária ...............................................171

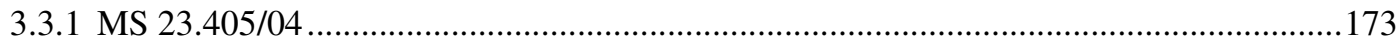

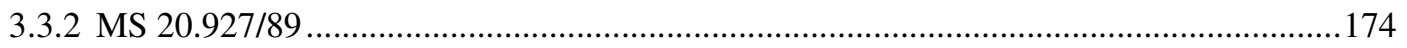

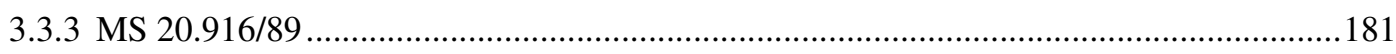

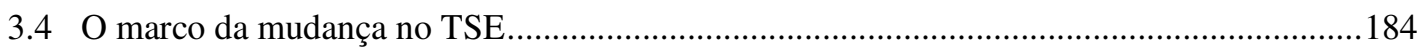

3.4.1 Consulta N. 1.398-TSE - O voto do relator e os principais argumentos pró-fidelidade...186

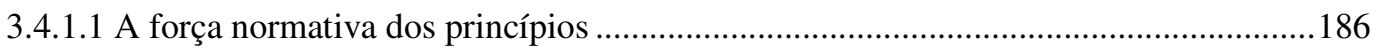

3.4.1.2 Possíveis razões para a migração partidária e a "traição ideológica".............................188

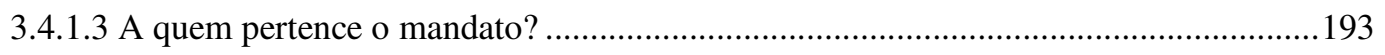

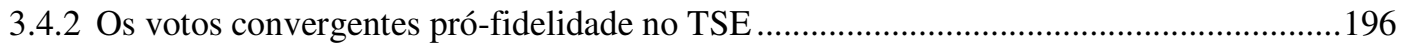

3.4.2.1 Como os eleitores veem a troca de partidos? ……….................................................202

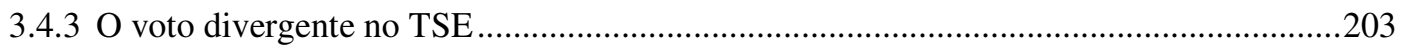

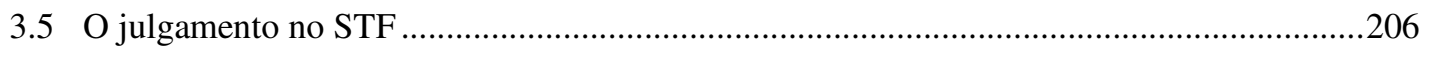

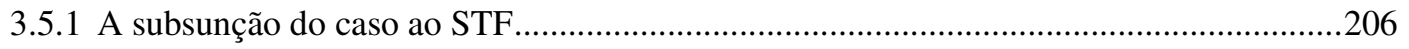

3.5.2 O parecer do Ministério Público Federal ……................................................................208

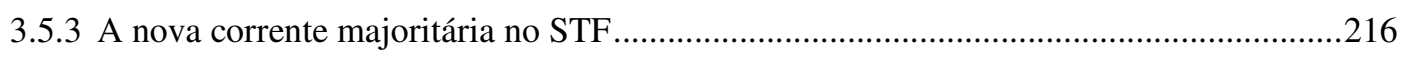

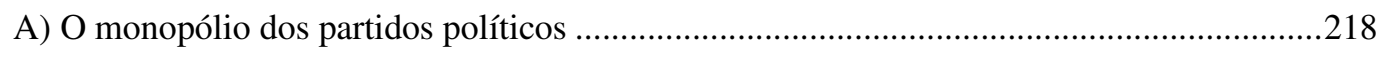

B) $\mathrm{O}$ valor da fidelidade partidária para o sistema proporcional.............................................220

C) O mandato representativo, o "duplo vínculo" e a "dupla fidelidade" .................................222

D) A interpretação principiológica e alteração jurisprudencial ...............................................223

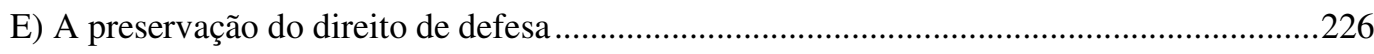


F) A legitimidade do STF para julgar a questão

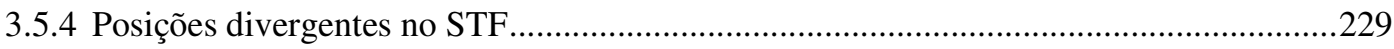

3.5.4 A ausência de direito líquido e certo ...........................................................................229

3.5.4.2 A ausência de previsão para a perda do mandato por infidelidade partidária ..............230

3.5.4.3 A inovação constitucional por meio de interpretação ................................................231

3.5.4.4 Representantes do povo ou do partido? ...................................................................232

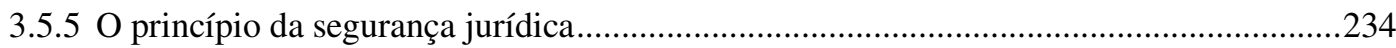

3.5.6 Ativismo judicial e a interferência entre os Poderes ......................................................239

3.5.7 A natureza da representação política em face da decisão do STF.....................................244

3.6 Os desdobramentos decorrentes da decisão do STF e o questionamento da constitucionalidade da Resolução N. 22.610/07 do TSE.................................................................245

3.6.1 ADI 3.999 e ADI 4.086 - A constitucionalidade da Resolução N. 22.610/07 do TSE...248

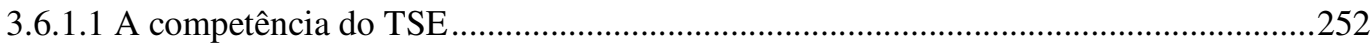

3.6.2 O cumprimento pelo Legislativo da decisão da Justiça Eleitoral de perda do mandato...252

3.7 Os mecanismos apropriados para inclusão da fidelidade partidária no ordenamento jurídico...

3.8 A perda de mandato por infidelidade após o marco regulatório ............................................263

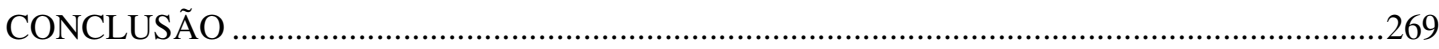

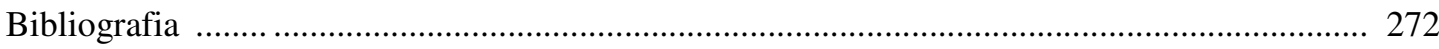




\section{INTRODUÇÃO}

A Constituição da República Federativa do Brasil lança as bases do Estado brasileiro em seu primeiro Título - Dos Princípios Fundamentais - e em seu primeiro artigo, definindo-o como um Estado Democrático de Direito, estabelecendo que todo poder emana do povo e seu exercício, regulado pelo texto constitucional, é direto ou via representantes eleitos.

A relevância dos temas eleitorais não reside somente no fato de estarem profundamente enraizados nas bases do Estado Democrático de Direito, todavia no sentimento da sociedade de que distante se está do verdadeiro ideal da democracia. $\mathrm{Na}$ realidade, muito mais próximo se está de um Estado de mera legalidade, cuja inversão de papéis mostra que a sociedade é servil às normas que criou e não o Direito serve ao povo como regulamentador das relações e condutas sociais. A soberania popular se esvanece diante de um Estado Eleitoral de Direito, no qual o circo se monta para a disputa do poder, revestido de caráter aparentemente democrático e em nome do exercício do poder do povo, quando de fato, o que se presencia é uma grande guerra eleitoral objetivando a conquista do poder para parcas oligarquias. Talvez esteja certa a profecia de Rousseau, para quem o povo se engana ao pensar que exerce de fato seu poder. Findas as eleições, há uma sensação de que o povo volta à sua condição de mero espectador, manipulado pelos dirigentes da nação. $\mathrm{O}$ exposto, por si só, deixa transparecer o incômodo que causa à sociedade a malversação do poder. A nação anseia pela prevalência da ética e da moral, diante de inúmeros e cotidianos casos que revelam a corrupção na política e cobra, de seus representantes, uma atuação efetiva.

Na busca de uma solução para as mazelas políticas da nação brasileira insere-se a atuação do Poder Judiciário que, diante da inércia do Legislativo em promover uma profunda e eficaz reforma política, assume um papel de moralizador das instituições e promotor dos princípios democráticos. Por mais altivas que sejam suas intenções, ao afetarem um dos mais delicados institutos da democracia - as eleições -, as recentes decisões proferidas sobre matéria eleitoral merecerão cuidadoso estudo, com a intenção de vislumbrar eventual desvirtuamento das bases democráticas sob as quais se assenta o Estado brasileiro. 
É justamente nesse ponto que reside a problemática a se enfrentar. A presente dissertação possui como objetivo geral a verificação dos reflexos da jurisprudência recém formada acerca de questões eleitorais. Como objetivo específico, o estudo intenciona verificar como as alterações promovidas pelas recentes decisões das Cortes pátrias e a forma pela qual têm sido efetivadas propagam seus efeitos sobre o Estado Democrático brasileiro. Esse "ativismo judicial” traz resultados positivos, em um crescente movimento de busca da maturidade democrática, ou, ao contrário, atenta contra os princípios basilares do Estado de Direito e provoca maior insegurança jurídica? Em outros termos, a hipótese com que se depara na observância do conjunto das decisões mencionadas, resume-se na seguinte indagação: diante da recente jurisprudência eleitoral, a sociedade brasileira está no caminho do aprimoramento do regime democrático, preservando a legitimidade de suas instituições e a unidade do ordenamento que a rege ou, inversamente, os eventuais avanços promovidos na ânsia de uma moralização política trouxeram, na verdade, sérios desvirtuamentos da democracia e suas instituições?

Ao se tentar responder a essa complexa questão, primeiramente, deve-se limitar seu amplo espectro. O fio condutor do presente estudo se perfaz no exame do conjunto de decisões judiciais selecionado. Intenciona-se delinear, a partir da análise desta jurisprudência eleitoral recente, possíveis respostas à hipótese supra levantada, verificando-se o modo pelo qual tais julgados promoveram mudanças qualitativas no sistema político-eleitoral e quais suas consequências para o proclamado Estado Democrático de Direito.

Para tal mister, o trabalho se divide em três capítulos. O primeiro capítulo deverá expor em sua abertura conceitos básicos, porém fundamentais, atinentes ao entendimento do complexo e dinâmico conceito da Democracia em seus três momentos históricos e de seus elementos que marcam a sociedade do século XXI e se fazem presentes na Constituição da República brasileira. Objetiva-se, nessa parte inicial, o estudo de tópicos relativos ao Estado Democrático de Direito. A dissertação deverá descrever brevemente a evolução da democracia e as diferentes conceituações que acompanham o significante ao longo da história, discorrendo-se sobre a teoria da representação política e sua natureza, buscando revelar os tipos de mandatos políticos previstos pelo ordenamento jurídico. Será traçado um breve quadro do instituto dos partidos políticos, tendo como pano de fundo a passagem da democracia representativa para o Estado de Partidos, o que esclarecerá o momento atualmente vivenciado, resultante da evolução histórica do Estado de Direito. Para caracterizar a hodierna democracia pátria, nada mais marcante do que a 
constatação do Ministro Gilmar Mendes: "a democracia virou um valor em si mesma”. O Ministro, na função de presidente do STF, ressaltou a força da Carta Constitucional de 1988, alçando-a como a responsável pela estabilidade institucional vivenciada no país desde sua promulgação, sobrevivendo a diversos percalços como confisco de poupança, planos econômicos, impeachment presidencial, crises políticas diversas, entre outros fatos.

Para entendimento do contexto atual e da forma como foram obtidas as conquistas relatadas, necessário um exame anterior, detendo-se no conhecimento das teorias sobre a representação política, a natureza do mandato representativo e a respectiva diferenciação entre o mandato livre e o mandato vinculado, o que, por certo, auxiliará no entendimento dos casos concretos a serem analisados na segunda parte da dissertação, trazendo os fundamentos para uma análise crítica das decisões proferidas pelos Tribunais.

Visando embasar o estudo dos temas presentes na jurisprudência eleitoral, primordial a compreensão do instituto do partido político, sua origem e evolução no país e nas democracias ocidentais hodiernas, pois esta permitirá situar claramente o momento histórico em que a democracia pátria se encontra, com destaque para o papel do partido político no regime democrático e seu crescente poder face as instituições da nação.

Lançadas as bases para uma análise crítica dos julgados que tanta perplexidade causaram, levando a se falar em "ativismo judicial", "interpretação expansiva", "novos rumos das Cortes" e "invasão do campo do Legislativo pelo Judiciário" e colocada a problemática central, passa-se ao exame propriamente dito da jurisprudência eleitoral.

Inaugurando o segundo capítulo desta dissertação, o tópico inicial cuidará do tema das coligações partidárias e a polêmica verticalização imposta por decisão do Judiciário. A metodologia estabelecida para o estudo desse item - e que se aplicará a todos os casos aqui examinados - prevê que seja percorrida, passo a passo, cada decisão, fórmula necessária e adequada para capitulação dos argumentos apresentados nos votos.

A jurisprudência que definiu o número máximo de Vereadores por Município será o próximo objeto de análise. O tema se inicia com o estudo da Lei Orgânica do Município paulista de Mira Estrela, que foi julgada inconstitucional pelo STF e se prolonga até a recente promulgação da Emenda Constitucional que ampliou o número de vagas nas Câmaras Municipais do país. 
Outro tópico concernente às eleições municipais compõe o quadro da recente jurisprudência eleitoral. Trata-se da migração dos Prefeitos que buscam a continuidade no cargo de Chefe do Executivo municipal em municípios vizinhos àquele em que haviam sido reeleitos - circunscrição na qual não poderiam gozar de um terceiro mandato. O fenômeno dos prefeitos itinerantes foi recentemente analisado pelas Cortes de Justiça nacionais, fazendo com que o tema se revista de especial atualidade para esse estudo.

Completa-se o quadro de análises do segundo capítulo com o exame da cláusula de barreira, estabelecida pela Lei 9096/95. Com vigência plena inicialmente prevista para o certame de 2006, jamais seria aplicada, por decisão do STF, garantindo sobrevida aos partidos denominados "nanicos".

Entende-se que, para completude da presente dissertação, não seria possível compreender o fundamento das decisões proferidas, tampouco o que se convencionou chamar de "interpretação expansiva" das Cortes, ou ainda verificar eventual desvio de direção da interpretação jurisprudencial pelos Tribunais, sem conhecimento das bases e dos limites da interpretação constitucional. Primordial, pois, enveredar pelos conceitos básicos da hermenêutica constitucional, recuperando seus principais ensinamentos, trazendo os ensinamentos da corrente denominada tradicional e sua contraposição com novas correntes de pensamento, que se intitulam de neoconstitucionalismo ou pós-positivismo. Colocado o suporte teórico, será possível pontuar em cada decisão como a interpretação adotada pelas Cortes promoveu significativas alterações na jurisprudência eleitoral.

Outro ponto polêmico que transparece nas decisões em exame diz respeito à competência normativa do TSE e os limites de sua atuação. A objeção que surge, quando do debate em foco, consiste em eventual invasão pelo Judiciário no campo legislativo, principalmente pela Corte Eleitoral, na edição de normas regulamentadoras. Em outros termos, o que se põe em discussão são os limites do poder normativo do TSE, à medida que se deseja averiguar possível extrapolação desse poder. $\mathrm{O}$ exercício de funções legislativas ao editar normas que eventualmente exorbitem a competência dessa Justiça Especializada implicaria clara violação do princípio fundamental da Separação de Poderes.

Em novo e final capítulo, o estudo segue a percepção de que na análise da recente jurisprudência eleitoral, a fidelidade partidária constitui, sem dúvida, o tema mais controvertido, como pôde se notar na mídia e no meio jurídico. O julgamento pelo 
STF que decidiu em final de 2007 que o mandato pertence ao partido político é tido como um dos maiores - senão o principal - exemplos de ativismo judicial.

Por atingir frontalmente a representação política, pilar da democracia, travou-se um intenso debate social, que por vezes tocou em um ponto sensível do regime democrático que é a harmonia dos Poderes. Graças às decisões judiciais superiores, saíram fortalecidos os partidos políticos. Porém a decisão não foi suficiente para quebrar o personalismo que permeia a cultura política pátria. Tanto assim, que dois anos após a decisão do STF que estabeleceu a punição ao ato de infidelidade partidária, não há exemplos de Governadores e Senadores que tenham perdido seus mandatos por troca de agremiação, e poucos foram os Deputados Federais apenados. De outro lado, o Legislativo promove, ao seu ritmo, a criação de normas que permitam as trocas partidárias (a chamada "janela da infidelidade"). A observação dos recentes julgados em matéria eleitoral permite, inclusive, aventar-se que novos embates surgirão entre Legislativo e Judiciário em torno da questão.

Esses são apenas parte dos componentes do assunto político-jurídico mais comentado ultimamente. Seu estudo faz jus, desta forma, a todo um capítulo dedicado à fidelidade partidária, para o exame do deslinde dos julgados e o respectivo impacto sobre o Estado Democrático de Direito.

No intuito de facilitar a leitura, explicita-se nesse intróito a sistemática adotada para a inserção de referências bibliográficas e de comentários, que se apresentarão sob a forma de notas de rodapé. Assim, quando da primeira citação a qualquer obra, será colocada sua referência integral, contendo, quando disponível: autor, título da obra, edição, local, editora, ano de publicação e as páginas consultadas. Nas seguintes citações da mesma obra será mencionado que esta foi anteriormente citada, indicando-se as páginas que contêm o referido conteúdo. Mesmo nos casos em que a referência a mesma obra se faça logo em sequência, repetir-se-á o nome do autor e obra empregando-se a expressão "cit." quando houver citação completa anterior no capítulo.

As referências bibliográficas completas encontram-se detalhadas ao final do trabalho. No corpo do texto, optou-se por utilizar o nome dos autores em letras de 'caixa alta' para uma melhor localização destes. Na primeira oportunidade em que o nome é mencionado no texto, será feita a transcrição integral de nome e prenome do autor da obra, para permitir ao leitor melhor identificação. Nas alusões seguintes ao mesmo autor, o 
nome aparece abreviado por suas iniciais seguidas do(s) prenome(s) pelos quais o autor é conhecido.

A metodologia aplicada segue as indicações de EduARdo C. Silveira MARCHI no curso de pós-graduação da Faculdade de Direito da Universidade de São Paulo e em sua obra Guia de metodologia jurídica: teses, monografias e artigos, da qual se extraíram as técnicas adotadas neste trabalho.

Por fim, cabe salientar que os critérios adotados relativamente aos aspectos formais desta dissertação seguem as diretrizes traçadas pela Comissão de PósGraduação da Faculdade de Direito da Universidade de São Paulo, em especial as Resoluções 01/2002 e da Portaria CPG-FDUSP / N. 02/2009. 


\section{DEMOCRACIA E REPRESENTAÇÃO POLÍTICA}

\subsection{A democracia}

Um dos principais objetivos da sociedade hodierna ocidental tem sido o aperfeiçoamento de suas instituições e de seu modelo político, de forma a se aproximar ao máximo do ideal da democracia. Uma sociedade cujas esferas de decisão exercem seus poderes de modo desfavorável a uma construção democrática não realiza os valores da democracia. Em consequência, o mesmo propósito se apresenta quanto aos aspectos eleitorais: busca-se tanto o aprimoramento democrático, por meio do refinamento dos processos que compõem o sistema eleitoral, bem como a verificação da legitimação dos órgãos atuantes nesta seara. Desse quadro inicial se extrai a importância da compreensão do complexo conceito da democracia, principalmente ao se propor uma análise do produto da atuação de alguma das principais instituições do Estado Democrático de Direito e seus reflexos para a democracia brasileira. Considerando-se o escopo deste estudo, são objetos de análise especificamente os julgados da Corte Eleitoral e da Corte Suprema sobre matéria eleitoral.

Muito se fala em crise da democracia, como sendo um modelo político que não entregou o que prometeu, ou ainda, sob outro prisma, que sua efetivação está condicionada à supressão de certos entraves, difíceis de serem transpostos. Quaisquer dessas afirmações têm como fundo uma noção idealizada de democracia, declarada, de modo simplório, como o regime em que todos, sem exceção, participam do processo decisório e determinam o que é o melhor para o bem geral. O contraste entre a concepção ideal e a realidade causa frustração, de uma parte. De outra, deixa a permanente luta em prol do melhoramento das instituições que compõem esse modelo, visando aproximá-las do ideal democrático como então concebido, ou seja, uma meta a ser perseguida.

A definição de democracia não encontra uma unicidade conceitual. Porém, algumas constatações devem ser trazidas à tona, a partir da contribuição dos principais autores sobre o tema, pois se propõe aqui um estudo dos reflexos da jurisprudência eleitoral sobre o Estado Democrático. Para se aperceber dos impactos causados ao Estado Democrático, essencial, inicialmente, uma breve capitulação de suas 
principais características, bem como de rápidas digressões sobre temas relativos à Democracia e as diferentes visões acerca desta ao longo da história.

Para a adequação e padronização dos termos que serão empregados, adota-se a diferenciação proposta com maestria por MANOEL GONÇALVES FERREIRA FILHO entre forma, regime e sistemas de governo ${ }^{1}$. De maneira sumária, a primeira se relaciona com a filosofia política, abstraindo-se a realidade e extraindo-se sua essência: a forma de governo, uma definição do modo de atribuição do poder, a partir da qual se extraem espécies de governo. O regime de governo, por sua vez, surge do exame da realidade, da prática de um modo de exercício do poder político por meio dos atos de governo. Da observação identificam-se princípios que conformam um sistema de governo, que correspondem à tradução da forma em normas constitucionais. De certa instância, o presente estudo perpassará tanto pela essência, quanto pelo plano do ser confrontado com o campo do dever-ser - emprestando-se os termos do autor. E não se poderia imaginar de forma diferente, pois interessa nesse instante compreender a essência da democracia, que, apesar de seus diferenciados conceitos e formulações vislumbrados em distintas épocas, mantém seus elementos fundamentais. Por sua vez, o regime de governo democrático é o pano de fundo do estudo, pois os reflexos da jurisprudência em análise se encontram no plano da existência fática. E, por fim, o campo do dever-ser confronta a teoria com a realidade, sugerindo modificações, apontando divergências, propondo correções, o que justifica sua inclusão no escopo desse Capítulo.

\subsubsection{As diferentes formas históricas assumidas pela democracia}

A compreensão da democracia se firma através da análise de três momentos historicamente marcantes, que correspondem às três visões da democracia, como classificou M.G. FerReIRA FILHO². Para José AFONSO DA SiLVA ${ }^{3}$ a democracia é um processo histórico, que, compartilhando com os dizeres de Monica HERMAN SALEM CAGGIANO $^{4}$, adapta-se a outros processos ao longo da história. Para Norberto BobBio ${ }^{5}$, a

\footnotetext{
${ }^{1}$ M. G. Ferreira Filho, Curso de Direito Constitucional, 34 a . ed., São Paulo, Saraiva, 2008, p. 77-79.

${ }^{2}$ M. G. FerreIRA FILHO, A democracia no limiar do século XXI, São Paulo, Saraiva, 2001, p. 1-36.

${ }^{3}$ Conforme o autor, "Democracia é um conceito histórico", cujo conteúdo é enriquecido em cada etapa. Trata-se, portanto, de um processo de conquista, onde o povo firma sua participação política e preserva seus direitos fundamentais. Um processo dialético que incorpora a cada etapa novos valores. Cf. J. AFONSO DA Silva, Curso de direito constitucional positivo, 27a. ed., São Paulo, Malheiros, 2006, p. 129.

${ }^{4}$ M. Herman SAlem Caggiano, aula proferida no curso de pós-graduação da Faculdade de Direito da Universidade de São Paulo, em 13.08.07.
} 
democracia se transformou com o tempo, sem pretender estabelecer uma idéia de aprimoramento ou de decadência, frisando que, aliás, o estado de contínua transformação é seu estado natural. Longe de ser uma fotografia de um momento histórico ou de um regime político de uma nação, suas feições se formam e se alteram ao longo de um processo evolutivo: a democracia é dinâmica, não estática.

\subsubsection{A democracia na visão antiga}

A primeira visão é obtida por meio do correto entendimento da democracia da antiguidade ou, mais especificamente, da democracia ateniense. Por mais que esta ostente a virtude da democracia direta, vários elementos mostram, ao contrário, um distanciamento do ideal democrático que se almeja contemporaneamente. O principal deles é a limitação da extensão da participação popular nas decisões políticas. Na Grécia antiga, a decisão era reservada aos cidadãos, universo extremamente restrito se comparado ao conceito de "povo" tal como aquele empregado na máxima "governo do povo, pelo povo e para o povo". Tal paradoxo decorre da idéia de liberdade dos antigos ser diametralmente oposta à dos modernos ${ }^{6}$. Ademais, a etimologia da palavra grega demos não se perfaz em um sinônimo de "povo", mas sim denota o lugar onde o povo mora, algo próximo de nossa noção atual de povoado. Portanto, para os gregos, democracia não era o governo do povo, mas dos povoados, ou em terminologia própria, das pólis ${ }^{7}$. Diante dessa premissa, a exigência frequente de expansão da democracia direta aos moldes antigos como medida de aprimoramento democrático é uma verdade incompleta ou insuficiente. Principalmente quando se atém ao sentido literal de democracia direta, que joga o facho de

\footnotetext{
${ }^{5}$ N. BobBio, O futuro da democracia, trad. Marco Aurélio Nogueira, 10a. ed., Rio de Janeiro, Paz e Terra, 2006, p. 19. Para o autor, o estado natural do regime democrático é a contínua transformação. O despotismo se apresenta sempre da mesma forma.

${ }^{6}$ J. Afonso DA Silva, Curso de Direito Constitucional Positivo, 27 a ed., São Paulo, Malheiros, 2006, p. 126 e ss.: "A democracia da antiguidade grega não é a mesma dos tempos modernos, nem a democracia burguesa capitalista corresponde à democracia popular.". V. também: M. G. FERREIRA FILHO, A democracia no limiar do século XXI, cit., p. 23-25; RENÉ RÉMOND, Introduction à l'histoire de notre temps - Le XIX . siécle 1815-1914, vol. 2, Éditions Du Sueil, p. 21-113. Benjamin Constant escreveu "Sobre a liberdade dos antigos comprada com a dos modernos" no ano 1819. A obra apresenta a diferença da liberdade dos indivíduos face ao Estado da liberdade dos indivíduos no Estado. Cf. J. Rivero e H. MOUTOUH, Liberdades públicas, trad. Maria Ermantina de Almeida Prado Galvão, São Paulo, Martins Fontes, 2006, p. 54. Cf. CELSO LAFER, $O$ moderno e o antigo conceito de liberdade, in Ensaios Sobre a Liberdade, São Paulo, Perspectiva, 1980.

${ }^{7}$ Conforme ensina S. RESENDE DE BARRos, a palavra pólis do grego antigo não se traduz por cidades, nem por estados, tampouco por cidades-estados. Tratava-se de uma espécie de unidade de organização política, tal como na Federação brasileira tem-se os municípios. A noção mais próxima da realidade em termos de constatação fática é a de um conjunto de povoados. Cf. Contribuição dialética para o constitucionalismo, Campinas, Millennium, 2008, p. 37-42.
} 
luz apenas na questão da participação de todos em todas as decisões. Não apenas pela impossibilidade física e fática, que fora exequível na época em que os cidadãos gregos se reuniam nas ágoras, todavia pelo fato de não parecer ser este o elemento desejável ${ }^{8} \mathrm{e}$ suficiente para atingir a perfeição do ideal democrático. Anteriormente a isso aparecem as condicionantes não superadas pela democracia ocidental hodierna ${ }^{9}$, que serão objeto de consideração ainda nessa seção.

\subsubsection{A visão moderna}

Não se observa uma transição da democracia da antiguidade para a era moderna, muito menos uma evolução no sentido de aprimoramento. Ao contrário, durante esse período de passagem, até que se chegasse aos tempos modernos, tomava-se por certo o legado de Aristóteles, que a havia julgado como uma forma de governo ilegítima, decorrente do desvirtuamento da politea (república), esta sim a forma de governo que visava o bem comum.

A produção de teorias sobre formas e regimes de governo e o debate acerca do tema ficaram praticamente adormecidos até o século XVIII, a "era das luzes" cujos ideais iluministas se baseavam na razão e no indivíduo, inspirando as chamadas Revoluções Liberais. Essa filosofia justificou um movimento social de insatisfação com a forma de governo monárquica em regime de absolutismo caracterizado pelo poder centrado na figura do rei. Como reação a esta situação, buscou-se fundamento nos valores de liberdade e igualdade para justificar a redução do poder concentrado. Este era o objetivo de uma nova classe, denominada de burguesia, que adquirira o poder econômico e ansiava pela participação no poder político.

Nesse contexto, o regime de governo estabeleceu sua configuração moderna com base na doutrina de um poder a ser limitado, com elevado nível de tutela das liberdades. A percepção da transformação ocorrida na instância do Poder e a motivação dessa mudança são elementos chave para compreensão do regime de governo que passou a vigorar nessa época.

\footnotetext{
${ }^{8}$ N. BobBIO, O futuro da democracia, cit., p. 53-54.

${ }^{9}$ M. G. FERREIRA FILHO fala em "condições" para a efetivação da democracia enquanto N. BOBBIO menciona as "promessas não cumpridas" pela democracia. Cf. M. G. FERREIRA FILHO, A democracia no limiar do século XXI, cit.; N. BoBBIO, O futuro da democracia, cit.
} 
Em O espírito das leis ${ }^{10}$, obra que data de 1748, encontram-se os alicerces da teoria da separação de Poderes, primordial para desconcentração do poder absoluto, objetivo da sociedade moderna permeada por ideais liberais. A limitação do poder e a tutela das liberdades só se concretizariam pela separação dos Poderes, tal como sistematizado por CHARLES DE MONTESQUiEU. Com todas as propostas críticas socialistas, marxistas ou pluralistas, a tripartição dos Poderes é vista como forma necessária, não só para preservar as garantias, mas também para as transformações sociais, tanto assim que tal fórmula se mantém ainda hoje, para dar base a qualquer receita política atual.

Indo além da simples fragilização do poder absoluto por meio de sua fragmentação, C. MONTESQUIEU propunha uma instância de poder que trataria exclusivamente da formação da lei, garantia da liberdade individual e expressão da vontade dos governados. Estabeleceu, então, um Poder Legislativo e desenhou suas funções. Restou, porém, compreender quem formularia as leis ou quem comporia o Poder Legislativo, bem como identificar a distinção entre governantes e governados. Já se estaria aqui próximo da concepção democrática, no seu conceito mínimo de N. BoBBio ${ }^{11}$, que requer apenas a participação universal e ilimitada das pessoas?

Para se aventar qualquer resposta, deve-se trazer à razão o pensamento político de JEAN-JACQUES ROUSSEAU, com sua formulação do conceito da "vontade geral", contraposta à "vontade de todos". J. RouSSEAU recuperou, de certa forma, o sentido de democracia segundo o qual a deliberação dos cidadãos se processa de forma direta: o conceito da antiguidade ${ }^{12}$. A constituição da vontade geral ocorre através da participação de todos na formulação das leis, garantindo a liberdade, à medida que todos são governantes e governados ao mesmo tempo, sujeitos apenas ao que de interesse comum por eles determinado, por contraponto ao interesse de alguns (poucos ou muitos). Logo, preservada está a liberdade individual, que manteria as vantagens do pacto social de associativismo estabelecido. Em que pese a plena conformidade com a linha liberal, sua aplicação prática foi obstada por causa endógena à própria teoria: na era moderna, a deliberação direta de todos - exigência tácita para formação da vontade geral - era inviável, hipótese plausível, quiçá, em pequenos territórios com diminuta população.

${ }^{10}$ C. Montesquieu, O espírito das leis, $3^{\mathrm{a}}$. ed., trad. Pedro Vieira Mota, São Paulo, Saraiva, 1994.

${ }^{11}$ N. BobBio, $O$ futuro da democracia, cit., p. 30-31. A definição mínima de democracia a caracteriza por "um conjunto de regras (primárias ou fundamentais) que estabelecem quem está autorizado a tomar as decisões coletivas e com quais procedimentos" (grifos no original)

${ }^{12}$ J. Rousseau, Do contrato social, trad. Márcio Pugliese e Norberto de Paula Lima, São Paulo, Hemus, s. a. 
Porém, retomando-se a questão sobre a definição dos grupos antagônicos - governantes e governados - é de se notar que da inexequibilidade da reunião do povo para deliberações não decorre a razão pela qual C. MONTESQUIEU apresenta sua forma viável de exercício do poder. Antes pela questão da aptidão intelectual necessária para o exercício da função de governante é que o pensador fundamenta sua teoria: não são todos do povo capazes de debater e legislar. Todavia, são hábeis na identificação daqueles mais aptos a essas tarefas. Logo, ao povo cabe escolher os que melhor o representarão para questões decisórias, por meio de eleições ${ }^{13}$. Estavam lançadas as bases da teoria da representação ${ }^{14}$ - ou em termos políticos, do governo representativo.

De outra face, J. ROUSSEAU desconsiderava qualquer outra maneira de expressão da vontade que não a direta. Em outras palavras, a vontade representada não levaria à vontade geral, eliminando-se, assim, qualquer possibilidade de triunfo fático de um regime democrático. Por essa razão, pode-se aventar a imprecisão da expressão "democracia moderna", pois à época não se observava um regime de governo com elementos próprios da democracia, sendo também falso se falar em "democracia representativa”. SÉRGIO RESENDE DE BARROS alerta para o erro de se considerar que as Revoluções Liberais introduziram a democracia representativa. Diante da óbvia impossibilidade prática do exercício do poder de forma direta, tal como pela reunião dos cidadãos nas ágoras, surgiu como uma necessidade da era moderna a fórmula da representação, a única encontrada para operacionalizar a escolha dos governantes, apesar dos problemas persistentes e do pouco progresso realizado. Com propriedade, relembra o autor, que os movimentos revolucionários setecentistas trouxeram a representatividade, os governos representativos ${ }^{15}$, fundadas no pensamento liberal. Mas não propalaram uma produção democrática, o que somente se observaria de fato com a extensão do voto. A denominada democracia indireta, liberal ou representativa do século XVIII não apresentava o povo no poder ${ }^{16}$. Tratava-se no máximo de uma "democracia sem povo", termo que soaria, no mínimo, contraditório. Importante, portanto, frisar que o liberalismo não introduziu a democracia representativa. M.G. FERREIRA FILHO alerta para o fato de que em nenhum dos maiores pensadores da época encontra-se a afirmação de que o governo

\footnotetext{
${ }^{13}$ Diferenciando-se, aí, da democracia antiga, para a qual o método democrático de escolha era o sorteio.

${ }^{14}$ Para a qual se dedica, ainda nesse capítulo, um item para seu estudo com mais detalhes.

${ }^{15}$ S. RESENDE DE BARROS, Contribuição dialética para o constitucionalismo, cit., p. 40-65 e aula proferida em 15/08/07 no curso de pós-graduação da Faculdade de Direito da Universidade de São Paulo.

${ }^{16}$ Como observa M. Herman SAlem Caggiano, até a reforma eleitoral inglesa de 1832, seu Parlamento era escolhido por um diminuto corpo eleitoral, pois o sufrágio era restrito a poucos. Direto Parlamentar e Direito Eleitoral, Barueri, Manole, 2004, p. 13.
} 
representativo se identificava com a democracia. Mais do que isso: não pretendiam que a democracia se instalasse, o que estava em conformidade com as premissas de ilegitimidade dessa forma de governo, traçadas por Aristóteles ${ }^{17}$. J. AFONSO DA SILVA reforça a colocação, detectando claramente o ponto crucial da assertiva ao afirmar que:

"O regime representativo, no Estado burguês, (...) procura resolver o conflito de interesses sociais por decisões da maioria parlamentar. Maioria que nem sempre exprime a representação da maioria do povo, porque o sistema eleitoral opõe grandes obstáculos à parcela ponderável da população, quanto ao direito de voto, para a composição das Câmaras Legislativas." 18

Reforça-se esse entendimento com Sieyès, que desenhou as linhas do modelo de governo representativo, diferenciando-o da democracia, que a ele repugnava. A nação, ao invés do povo, formada a partir de um pacto social, detinha o poder soberano. Com base na idéia de representantes da nação e não do povo, justificava-se a combinação monarquia-representação, na qual o monarca era o representante dos interesses da nação. Por sua vez, a vontade da nação espelha a vontade geral e é expressa através dos representantes.

Prevalecia, à época, o sufrágio censitário, justificado por serem aqueles que pagam tributos os mais interessados pelos negócios públicos. Essa limitação na participação do poder político impedia que o governo representativo moderno fosse então caracterizado como um regime democrático, mas sim visto como um governo aristocrático, emanado das classes burguesas, a classe detentora e do poder econômico e por consequência, do poder político. A aceitação da democracia como regime de governo somente viria em meados no século XIX. Essa evolução somente seria observada com a expansão dos limites restritivos do sufrágio, de forma gradual na Inglaterra e por meio da Revolução francesa de 1848, que proclamou a Constituição do mesmo ano, estendendo a participação popular no processo de escolha de representantes e caminhando no sentido do sufrágio universal, fato que possibilitou, a partir de então, a denominação de democracia representativa. O governo representativo evolui para uma democracia representativa moderna transformando-se em um regime de governo aberto a maior participação popular, não sendo, porém, o povo em sua totalidade quem toma as decisões (pois fisicamente

\footnotetext{
${ }^{17}$ M. G. Ferreira FILHO, A democracia no limiar do século XXI, cit., p. 15.

${ }^{18}$ J. AfOnSo DA SIlva, Curso de Direito Constitucional Positivo, cit., p. 130-132.
} 
impossível), mas os representantes eleitos, que o fazem em seu nome. A democracia indireta era a democracia possível, ao final da era moderna ${ }^{19}$.

\subsubsection{O Estado de Direito}

Antes de desenhar os contornos do estágio atual da democracia, é necessário traçar um paralelo entre as transformações da democracia presenciadas até o final da era moderna e a evolução do Estado de Direito, para se compreender a terceira e atual visão da democracia, a democracia hodierna ${ }^{20}$. A correlação entre a democracia e o Estado Democrático de Direito faz com que quaisquer impactos negativos a este importem um retrocesso quanto aos ideais daquela, ou seja, um verdadeiro caminhar na contramão da história. A evolução da sociedade ocidental pode ser contada sob diferentes prismas. Entre os afetos ao tema do presente estudo, tem-se o aspecto das transformações da democracia, que apresenta as três visões aqui estudadas; o enfoque da doutrina dos direitos humanos fundamentais, que apresenta as três gerações ou dimensões destes; por fim, a visão do constitucionalismo e a ótica da formação dos Estados e governos, que constroem um quadro evolutivo do Estado de Direito. Opta-se, nesse momento, por focar na evolução do Estado de Direito, trançando-se um paralelo entre as suas transformações e as da democracia ao longo dos últimos séculos.

Pretende-se, de forma breve, repassar a evolução do Estado de Direito, sublinhando-se os principais aspectos atinentes ao tema, especialmente no que tange às instituições e procedimentos democráticos. Ademais, a compreensão da construção do Estado de Direito nos últimos quatro séculos mostrará, conforme relata J. AFONSO DA Silva, que o Estado Democrático de Direito, em que pese conter os princípios do Estado de Direito e da democracia, não é uma simples adição dos elementos, porém, "um novo

\footnotetext{
${ }^{19}$ De acordo com M. G. FERREIRA FILHO, a partir desse momento na história, todas as críticas feitas à democracia indireta não lograram muito mais do que vislumbrar maneiras de aprimorar a democracia representativa, visando aumentar o grau de democracia dos regimes de governo. Inclui-se, portanto, no rol dos aprimoramentos da democracia representativa a transição para o modelo da democracia pelos partidos, bem como a inserção de instrumentos procedimentais característicos da democracia direta. A democracia no limiar do século XXI, cit., p. 15 a 23.

${ }^{20}$ Adotou-se, na presente dissertação, a expressão "hodierna(o)" para caracterizar aqulio que é atual, isto é, que se refere aos dias de hoje. Assim, a democracia hodierna é aquela vinvenciada na atualidade. Outros termos que são amplamente adotados na doutrina como sinônimos de algo "atual' são os adjetivos "contemporânea(o)" ou "moderna(o)". Ambos podem trazer o aspecto de "atualidade", conforme ao que se compara. Nesse sentido, algo "moderno" poderia ser atual, ao se comparar com algo "antigo". Para melhor localização no tempo, preferiu-se padronizar a adjetivação traçando um paralelo às fases clássicas da história: Idade Antigua, Idade Moderna e Idade Contemporânea, destacando-se desta os tempos atuais (hodiernos).
} 
conceito que os supera, na medida em que incorpora um componente revolucionário de transformação do status quo" ${ }^{21}$. Observar-se-á como se processou essa transformação que atribuiu, na organização política do Estado Democrático de Direito, o poder ao povo. O caminho trilhado pelo do Estado de Direito até hoje, visualizado sob o aspecto político, coincide com o paulatino alargamento da participação popular no processo decisório e, assim por dizer, da introdução gradual dos elementos essenciais à democracia.

De início, importa ressaltar que nem todo Estado é um Estado de Direito. É o que afirma ELÍAS DÍAZ GARCÍA ${ }^{22}$. De acordo com o autor, não é a simples existência de uma ordem jurídica ou sistema de legalidade que proporciona um Estado de Direito. O Direito deve ser entendido nesse caso, como a expressão da vontade geral de que falava J. Rousseau. Assim, o Estado só é de Direito como Estado com Poderes regulados e limitados pela lei, em contraposição a qualquer forma de Estado absoluto e totalitário. Para ser caracterizado o Estado como de Direito, algumas características gerais são fundamentais: o império da lei, como limitante e regulador dos Poderes do Estado e expressão da vontade geral $^{23}$; a separação dos poderes $^{24}$; a legalidade da administração, que deve atuar de acordo com a lei e submeter-se a um suficiente controle judicial; e a garantia e efetiva realização de direitos e liberdades fundamentais.

A fórmula Estado de Direito se encaixa em diferentes contextos sócioeconômicos ao longo da história. As diferentes vestes assumidas pelo Estado de Direito são categorias históricas de organização político-jurídica das comunidades, de criação da cultura política ocidental. E. DÍAZ GARCÍA diferencia as três clássicas etapas do Estado de Direito, caracterizando o Estado Liberal, o Estado Social e o Estado Democrático ${ }^{25}$.

J. Afonso DA SILVA afirma que o Estado de Direito "surgiu como expressão jurídica da democracia liberal” ${ }^{26}$. Conforme já explanado não haveria de se empregar o termo "democracia" nesse momento. Mais preciso seria apontá-lo como

${ }^{21}$ J. Afonso DA Silva, Curso de Direito Constitucional Positivo, cit., p. 112.

${ }^{22}$ E. DíAz GARCÍA, Estado de derecho y sociedad democrática, in Cuadernos para el Dialogo, Madrid, 2000, p. 13.

${ }^{23}$ Como adverte E. DÍAZ GARCÍA, não basta o império da lei. Esta deve advir de uma assembleia de representação popular livremente eleita, enfim, a expressão da vontade geral, sob pena de se caracterizar tão somente o "Estado Legal", caracterizado por uma legalidade autoritária, representativa do interesse de poucos - como era no Estado Liberal, no qual os direitos protegidos eram os da burguesia - e não uma legalidade democrática. Estado de derecho y sociedad democrática, cit., p. 17, 29 e 39.

${ }^{24}$ Extraindo a essência do ponto que se relaciona com o presente estudo, o autor frisa: "no podrán ser considerados legisladores, em sentido estricto y formal, los órganos ejecutivos, a pesar de sus facultades normativas, ni tampoco los órganos judiciales del Estado”. Cf. E. DíAZ GARCíA, Estado de derecho y sociedad democrática, cit., p. 32.

${ }^{25}$ E. DÍAZ GARCÍA, Estado de derecho y sociedad democrática, cit, p. 13-39.

${ }^{26}$ J. Afonso DA SIlva, Curso de Direito Constitucional Positivo, cit., p. 112. 
consequência do liberalismo, que formulou a concepção do Estado Liberal de Direito. A evolução da sociedade liberal culminou na passagem deste ao Estado Social de Direito, cuja missão era a de garantir os direitos sociais. Todavia, sua insuficiência democrática proporcionou a emergência do Estado Democrático de Direito, constitucionalmente garantido. Mas não antes de provocar o surgimento de regimes antagônicos à democracia, durante a primeira metade do século XX.

O Estado de Direito é um estado "domesticado pelo direito" - nos termos de JOSÉ JOAQUIM GOMES DE CANOTILHO ${ }^{27}$ - encontrado inicialmente no ocidente Europeu e posteriormente nos EUA. Contudo, de forma mais exata, o termo Estado de Direito advém do Rechtsstaat alemão. Os Pilares do Estado de Direito moderno se fundam no Rule of Law inglês ${ }^{28}$, que propunha a prevalência das leis e costumes sobre o poder absoluto do monarca, a sujeição dos atos executivos ao Parlamento (representantes do eleitorado), o direito de acesso igual às cortes judiciárias, o devido processo justo e legal.

Por força do Estado Constitucional Norte-Americano, bem como das premissas do État Légal francês, somam-se, como estruturas basilares, ao modelo do Estado de Direito inglês: a) o poder constituinte pertencente ao povo, que através de uma norma superior regulamenta o ordenamento, mormente estabelecendo a forma $\mathrm{e}$ organização do governo, sujeito a uma Constituição; b) a legitimação e a justificação do poder, que motivariam a existência do governo ${ }^{29}$.

O Estado de Direito traz em seu núcleo princípios e valores para a realização de uma ordem social de justiça e paz. Sua efetivação se processa pelas instituições que estabelece e pelos procedimentos que determina, como forma de exteriorização do poder estatal sobre os governados $^{30}$. Se, de um lado, J. J. GOMES DE CANOTILHO possui uma visão mais abrangente das características gerais de um Estado de Direito, de outro, J. Afonso DA SiLVA entende que, na origem do Estado de Direito, seus valores fundantes eram os do liberalismo, que ditaram os elementos nucleares do então denominado Estado Liberal de Direito. O Estado Liberal aparece como formalização dos ideais liberais que fundamentaram a luta da burguesia contra o absolutismo. Em sentido

27 J. J. Gomes de CANotilho, Estado de Direito, in Cadernos Democráticos - Coleção Fundação Mário Soares, Lisboa, Gradiva, 1999. V. J. J. Gomes DE CANotilho, Estado de Direito, disponível (on line) in Buscalegis, América do Norte, 02909 2009, p. 9, 13.

${ }^{28} \mathrm{Na}$ definição de M. G. FERREIRA FILHO, o Rule of Law "consiste exatamente na sujeição de todos, inclusive e especialmente das autoridades, ao império do Direito." Cf. Direitos Humanos Fundamentais, 9a. ed., São Paulo, Saraiva, 2007, p. 12.

${ }^{29}$ J. J. GOMES DE CANOTILHO, Estado de Direito, cit., p. 9.

${ }^{30}$ Por isso a importância do estudo de suas instituições visando aperceber-se se na efetivação deste Estado são realizados os princípios democráticos. 
parelho, N. BobBIO coloca o Estado Liberal como o gérmen da democracia, uma vez que o Estado Liberal de Direito foi quem estabeleceu os mecanismos jurídicos que se apresentam como pressupostos necessários à caracterização de um regime democrático ${ }^{31}$. Apesar de não ser o regime de governo liberal uma democracia, pode-se afirmar que, se, por sua vez, as liberdades possibilitam o exercício democrático, a democracia garante os direitos de liberdade. O oposto também é verdadeiro: a ausência de liberdades dificulta ou impossibilita a democracia e a inexistência dessas facilita a supressão de tais direitos.

As Revoluções Liberais que introduziram o Estado Liberal de Direito proporcionaram a edição de declarações de direitos. A principal, a Declaração de Direitos do Homem e do Cidadão, legado francês do final do século XVIII (1789), bem como as demais declarações de direitos que lhe são contemporâneas, constitui o pacto social que antecede aos pactos políticos (as Constituições) e é consequência do reconhecimento dos direitos individuais. Seu estudo é primordial para a compreensão do Estado de Direito por conterem tais declarações as linhas básicas do constitucionalismo. Os elementos fundamentais do Estado de Direito aparecem no artigo $16^{\circ}$ da Declaração francesa: a existência de uma Constituição à qual se submeta o Estado, que garanta os direitos e limite os Poderes. Para existir um Estado de Direito, este deve estar organizado e regulado por uma Constituição elaborada pelos representantes da nação, que preveja a separação dos Poderes na formula clássica. Tem-se então o Estado Constitucional de Direito, no entendimento de J. J. GOMES DE CANOTILHO ${ }^{32}$.

Além dessas características, o Estado (Constitucional) de Direito apresenta a garantia dos direitos fundamentais em nível constitucional (à época do Estado Liberal de Direito tais direitos eram direitos individuais ou liberdades públicas) e está subordinado à autonomia individual. O exercício do poder estatal se processa por meio de instituições e instrumentos juridicamente concebidos e constitucionalmente determinados. Por incorporar os ideais liberais atinentes à esfera das liberdades individuais, sua primeira forma se transfigura no Estado Liberal de Direito.

Como proposta de associação política, o Estado Liberal de Direito é um Estado mínimo e sujeito a limites, com atuação restrita (à manutenção da ordem e da segurança pública), e cujo poder é estruturado com a finalidade de cumprir a função de preservação dos direitos naturais do homem - sendo esta também sua razão de existir -,

\footnotetext{
${ }^{31}$ N. BoBbio, O futuro da democracia, cit., p. 32.

32 J. J. GOMES DE CANOTILHO, Estado de Direito, cit., p. 8 -12.
} 
garantindo a liberdade e a propriedade privada ao mesmo tempo em que afasta o arbítrio ${ }^{33}$. Seu elemento nuclear é a lei, concebida de forma geral e abstrata de modo a gerar a justiça e a igualdade, através da razão e de sua abrangência universal ${ }^{34}$. Somente a lei pode fixar os limites do exercício dos direitos naturais dos homens ${ }^{35}$ e punir os abusos, para que essa regulação seja justa e, portanto, legítima. Tal lógica decorre do fato da lei, tal como concebida no liberalismo, ser, em primeiro plano, a lei formal, aquela elaborada pelo Poder Legislativo. Em segunda instância, ela é a expressão da justiça, de um lado, e da vontade geral, de outro. E para tanto, deve refletir o princípio da igualdade entre os homens, sendo aplicável de forma isonômica e uniforme para todos ${ }^{36}$.

No aspecto econômico, a filosofia de proteção às liberdades individuais e a ideologia do livre mercado e ampla concorrência - possíveis através do abstencionismo estatal - resguardava a propriedade privada e, assim, o poder econômico da classe que o detinha $^{37}$ em face das arbitrariedades do monarca, bem como restringia o poder do Parlamento desconectado com seus interesses. Apesar da mudança da ótica da relação governantes/governados ter evoluído de príncipe/súditos para uma relação governantes/cidadãos, o Estado Liberal de Direito não teve a presença do elemento popular na formação da vontade estatal, pois a liberdade moderna - como visto - não prevê a extensão da igualdade do direito de participação a todos.

No ocidente, o avanço do liberalismo na esfera política e econômica estava desconectado da realidade social. O modelo de capitalismo criado pelo liberalismo, separando os detentores dos meios de produção dos que possuíam a força de trabalho, provocou, com o advento da Revolução Industrial, uma concentração de riqueza para a classe detentora do poder econômico ${ }^{38}$. Diziam serem os indivíduos iguais entre si, mas as oportunidades de desenvolvimento não refletiam essa condição. Por seu caráter

\footnotetext{
${ }^{33}$ A finalidade do Estado Liberal está contida art. $2^{\circ}$. da Declaração de Direitos do Homem e do Cidadão. Cf. M. G. FERREIRA FILHO, Direitos Humanos Fundamentais, cit., p. 167-169.

34 “A Lei é regra para todos”. Cf. M. G. FERREIRA FILHo, Estado de Direito e Constituição, 2.ed., São Paulo, Saraiva, 1999, p. 21. J. Afonso DA SILVA, Curso de direito constitucional positivo, cit., p.117.

35 Declaração de Direitos do Homem e do Cidadão, art $4^{\circ}$. Cf. M. G. FerReIRA FilHO, Direitos Humanos Fundamentais, cit., p. 167-169.

${ }^{36}$ Declaração de Direitos do Homem e do Cidadão, arts. $1^{\circ}$. e $6^{\circ}$. Cf. M. G. FerreIRA FilHo, Direitos Humanos Fundamentais, cit., p. 167-169.

37 J. AFONSO DA SILVA coloca nessa classe dominante os grandes latifundiários, os capitalistas, o exército e os burocratas. Curso de direito constitucional positivo, cit., p. 118.

${ }^{38}$ Desde o final do século XVIII o estabelecimento do modelo capitalista da produção apresentou várias nuances, do capitalismo comercial, industrial, financeiro e tecnológico. Nenhuma dessas fugia da razão de existência do capitalismo ou sua motivação maior: a acumulação de riquezas, pela maximização do lucro. Os diversos ciclos de pujança e recessão observados nos últimos três séculos não mostraram outra fórmula senão a da alternância entre mais liberalismo e mais intervencionismo. A crise financeira global iniciada em meados de 2008 é prova recente do fato.
} 
estritamente formal, a igualdade prevista no Estado Liberal de Direito, baseada na lei geral e abstrata, não proporcionou os resultados materiais desejados pelos cidadãos, cuja insatisfação era crescente. Atribui-se às marés sociais, decorrentes da situação deteriorada de grande parcela da sociedade moderna - a classe trabalhadora, relegada à margem dos direitos sociais e econômicos - a derrocada dos ideais liberalistas. Esse fato foi fruto da própria concepção individualista do Estado Liberal e de sua insuficiência no provimento de tais direitos, ocasionadas pela filosofia da mínima intervenção estatal em todos os campos, mormente ao deixar a força de trabalho ser regulada livremente pelo mercado. Como consequência também se pode dizer que se criou espaço para o fortalecimento das idéias críticas marxistas segundo as quais a extrema formalidade liberal impedia o exercício dos direitos individuais e ensejava a existência de condicionantes sociais e econômicas para que os cidadãos possam de fato ter garantidos seus direitos fundamentais.

De outra face, como ensina M.G. FerReIRA FILHO, o sistema eleitoral do governo representativo, característico do estado moderno, esgotava-se em seus fundamentos de igualdade puramente formal, fazendo com que surgissem reivindicações pela expansão do sufrágio. Não obstante a presença de "preocupações sociais" - como denomina o autor - nas primeiras declarações de direitos, elas foram relegadas, uma vez que não era papel do estado provê-las ${ }^{39}$. Perante as hostis ameaças dos excluídos do bem estar social, insufladas por ideologias revolucionárias, a partir de meados do século XIX, as classes dominantes encontraram-se diante da possibilidade de abalo das instituições liberais com o surgimento de movimentos revolucionários. Decisiva foi a atuação da Igreja na Europa Ocidental, onde predominava a religião Cristã, por meio da edição da encíclica papal Rerum Novarum em 1891, formulando uma doutrina social que retomava o direito natural e o aspecto da dignidade humana. Possibilitava a combinação dos direitos ao trabalho e a subsistência mínima com a garantia da propriedade privada, a manutenção do status quo e pacificação das massas, afastando-se, por meio das narradas concessões, a real possibilidade de revolução, que se concretizava pelo socialismo soviético tomado pelo ideal marxista da ditadura do proletariado. A alternativa da "reforma" permitia a permanência do controle do poder político e econômico às classes dominantes - inclusive à Igreja - dentro do sistema capitalista de produção, ao mesmo tempo em que colocava o Estado como instrumento provedor das concessões necessárias, evitando assim a insurgência popular. O Estado Social que o sucedeu buscou aquietar as reivindicações das

\footnotetext{
${ }^{39}$ M. G. FERreIRA FILHO, Direitos Humanos Fundamentais, cit., p. 43-45.
} 
massas, fazendo-lhe concessões e assim mantendo o status da burguesia e os moldes capitalistas de produção, conforme frisa E. DíAz GARCíA ${ }^{40}$. De acordo com M.G. FERREIRA FILHO, tal postura reformista foi característica do positivismo jurídico, do socialismo democrático, do cristianismo social, que propunham o reconhecimento de direitos sócioeconômicos ao lado das conquistas então obtidas pelas Revoluções Liberais, como forma de perpetuá-las. Ao estado incumbia assegurar dimensão social às liberdades públicas. Configurava-se, então, o denominado Estado Social de Direito, um Estado material de Direito, voltado à realização da justiça social, por oposição ao individualismo liberal ${ }^{41}$.

Esse novo modelo de organização política foi refletido na Constituição Alemã de Weimar (1919), que marcou historicamente a previsão positivada dos direitos sociais ao estabelecer que o Estado deve agir, garantindo condições de bem estar aos cidadãos, assumindo a responsabilidade pela condução e organização da sociedade. São as liberdades positivas (direitos de crédito ou poderes de exigir) que não anulam, mas antes se adicionam às liberdades negativas (liberdades individuais de agir advindas do direito natural na concepção iluminista).

O Estado Social de Direito também se mostrou ineficaz na realização da justiça social. A introdução dos direitos sócio-econômicos desde o Estado Social de Direito do início do século $\mathrm{XX}$, o Welfare State, parece ter sido muito limitada a realizar as concessões da classe econômica e politicamente dominante para as massas, principalmente quanto às condições de trabalho. Não evoluiu mais além nas sociedades ocidentais e não obteve êxito com o comunismo. Sofreu, junto com o constitucionalismo, um grande abalo com a instauração de governos totalitários, que, sob o rótulo de Estado Sociais ou Estados Nacionalistas e garantidos por uma Constituição, proporcionaram o início de uma época de maior afastamento da democracia na era contemporânea. O mundo proclamado por Weimar colapsou. Economicamente, a maior depressão econômica do século. Era a prova de que não basta uma Constituição formal se as instituições do Estado não agirem de forma compatível com a democracia.

Porém, o esgotamento das fórmulas anteriores não implicou necessariamente o advento da democracia. É certo que a principal concessão da extensão do voto de maneira indistinta às massas possibilitou falar em democracia. Mas qual o real sentido de um Estado Democrático de Direito? Requer-se analisar se o Estado de Direito

${ }^{40}$ Cf. E. DíAz GARCíA, Estado de derecho y sociedad democrática, cit, p. 13-32.

${ }^{41}$ M. G. FERREIRA FILHO, Direitos Humanos Fundamentais, cit., p. 41-47. 
propiciou de fato instrumentos jurídicos que garantem a efetiva democratização sócioeconômica e não tão somente uma democracia formal.

Observou-se que o nacional socialismo trouxe à tona a questão da legitimação. Esta, por sua vez, foi um dos aspectos políticos da crise do Estado Social: não era suficiente para a legitimação do Estado de Direito justificar que o governo estivesse submetido às leis e fosse formado por representantes do povo, tampouco que os súditos do absolutismo se convertessem em cidadãos livres. Suas instituições e seus mecanismos de atuação deveriam transparecer o consentimento popular. Tanto assim, que os Estados totalitários da Segunda Grande Guerra se apresentavam como Estado de Direito ou como Estados Sociais, em uma concepção formal do Estado de Direito, que prescinde de toda e qualquer participação popular. Ao restringir-se o conceito do Estado de Direito à lei formal, como produção legislativa, configura-se, na verdade, um Estado de legalidade, uma deformação do Estado de Direito. Como confirma J. AFOnSo DA SILVA, apesar da importância da legalidade para o Estado de Direito, esta não se demonstra suficiente para sua realização ${ }^{42}$. O Estado ditatorial tentou legitimar-se com base em uma concepção formal da lei, que considerava bastante para se autodenominar Estado de Direito, mesmo que carente de instituições e mecanismos para a realização dos direitos fundamentais e sociais. Tratava-se, porém, de Estado de mera legalidade, cuja Constituição abrigava em seu corpo alguns princípios democráticos, mas cujas instituições não os concretizavam.

Para J. J. Gomes DE CANOTILHO, os Estados nazistas e fascistas eram "Estados de não-Direito", pois lhes faltava a legitimação do poder. Essa legitimação se estende às esferas públicas, inclusive às cortes judiciárias, pois estas "exercem a justiça em nome do povo". Em consequência, os juízes são agentes públicos, ou do povo, a quem este delega a tarefa de aplicação dos princípios da justiça constantes no ordenamento jurídico e na "consciência jurídica geral" e se utilizarão das ferramentas do Estado de Direito para consecução de suas funções, tais como o controle constitucional das leis ${ }^{43}$.

Os direitos sociais consagrados em Weimar padeceram de efetivação, motivando sua reiteração após a caótica situação da Europa depois da Segunda Grande Guerra. A reedição dos direitos individuais e sociais lado a lado, porém com uma nova roupagem, que os adicionaria aos direitos humanos fundamentais de terceira dimensão, encontrou sua formalização na Declaração Universal dos Direitos Humanos de 1948, promulgada pela Assembleia Geral das Nações Unidas. Os novos direitos faziam face aos

42 J. AFONSO DA SILVA, Curso de direito constitucional positivo, cit., p. 114.

${ }^{43}$ J. J. Gomes De CANotilho, Estado de Direito, cit., p. 3-7. 
desafios das nações devastadas pela Guerra valorizando a solidariedade e a qualidade de $v \operatorname{vida}^{44}$. O movimento da internacionalização das questões políticas visava à extrapolação das fronteiras nacionais como forma de evitar o fortalecimento do poder do Estado Nacional, que adquirira vida própria e permitira a extensão de sua autonomia além de suas fronteiras. Essa nova onda de internacionalização, transfigurada na Declaração que repudiou as guerras e demais acordos de âmbito global, visava garantir a existência dos direitos individuais e sociais independentemente da existência do Estado, transcendendo suas fronteiras, embora convivendo com este.

A necessidade hodierna de o Estado participar da comunidade internacional e ser por ela reconhecido é antes de tudo econômica, uma vez que as relações comerciais são globalizadas e ditam o fluxo das riquezas das nações. A aceitação das normas internacionais é uma característica do Estado de Direito hodierno e seu reconhecimento mundial (ao menos para as potências econômicas do ocidente) depende da incorporação dos elementos democráticos em seu sistema político. Ao menos, essa tem sido a justificativa que se presencia nas décadas após a Segunda Grande Guerra, seja durante o período da guerra fria, configurado pela luta da democracia americana contra a ditadura socialista, seja no dissenso recorrente entre americanos e governos totalitários como Cuba, Venezuela, Nicarágua, Iraque, entre outros. Os ideais que fundamentam esses conflitos são aqueles que apresentam princípios como a autodeterminação dos povos, a paz, a independência dos povos, a autonomia nacional, todos constantes de documentos internacionais, inaugurados com a Declaração de 1948 e presentes nas Constituições democráticas ocidentais vigentes.

O movimento pela absorção desses ideais pelas nações levou a uma cristalização da evolução dos direitos fundamentais, ao mesmo tempo em que abriu caminho para seu prosseguimento e deu novas forças ao abalado constitucionalismo, que tinha na Constituição e no ordenamento jurídico os instrumentos para internar o novo enfoque de internacionalização dado aos direitos e às questões políticas.

Em relação à democracia, observou-se uma expansão em seu significado, motivado pelas exigências advindas da interação internacional das nações, plano no qual a nova geração de direitos se desenvolvia. Dentre os diversos aspectos emergentes no pósguerra, cabe ressalvar a premência da participação popular na formação da vontade estatal.

\footnotetext{
${ }^{44}$ M. G. FERREIRA FILHO cita como exemplo dos novos direitos elencados os seguintes direitos: asilo, nacionalidade, liberdade de casamento, políticos, seguridade social, trabalho, repouso, lazer, saúde, educação, vida cultural, entre outros. Cf. Direitos humanos fundamentais, cit, p. 53 e 58.
} 
Essa exigência é a prova do esgotamento dos modelos do Estado Liberal de Direito e do Estado Social de Direito e a intenção de concretização do princípio da soberania popular é a causa da formação do que hoje se caracteriza como um Estado que abriga os princípios democráticos.

\subsubsection{O Estado Democrático de Direito}

Chega-se, então, ao Estado Democrático de Direito, que aparece para J. J. GOMES DE CANOTILHO ${ }^{45}$ não tanto como uma evolução do Estado de Direito, mas exatamente como uma necessidade do Estado Constitucional de Direito para cumprir com suas exigências não satisfeitas nas formulações do Estado Liberal de Direito e do Estado Social de Direito. A diferenciação básica para os modelos anteriores é a legitimação de sua ordem pela presença do povo na organização do poder e na construção do direito que resultarão na forma de governo. Como profere PAUlo BonAVIDEs ${ }^{46}$, o próprio Estado Democrático de Direito tem suas fases internas de desenvolvimento, dentre as quais, a simples formação das instituições representativas é antes um estágio inicial do Estado que almeja realizar os princípios democráticos.

O Estado de Direito como meramente limitador do poder político tem alcance restrito quanto às necessidades para um desempenho pleno do Estado. Os ideais de submissão ao império do direito, o "governo de leis e não de homens", as instituições germinadas sobre os princípios da legalidade não foram suficientes. Para J. J. GOMES DE CAnotilho, o que faltava ao Estado de Direito para sua plenitude era a legitimação democrática do poder ou, em termos simples, justificar de onde vem o poder.

A retomada das forças do constitucionalismo levou, por medo das guerras recentes, a pensamentos de que este era antagônico à democracia e não propício ao florescimento desta. O embate entre constitucionalismo e democracia é uma falsa retórica para J. J. Gomes DE CANOTILHO, ${ }^{47}$ que demonstra que a lógica de um trade-off entre direito ou democracia tem premissas infundadas. O autor afirma que "O Estado constitucional carece da legitimidade do poder político e da legitimação desse mesmo poder”. Não basta ao Estado limitar o poder, mas há a constante necessidade de legitimá-lo. São dois aspectos

45 J. J. Gomes de CANOTILHO, Estado de Direito, cit., p. 10.

${ }^{46}$ P. Bonavides, Do Estado Liberal ao Estado Social, $7^{\mathrm{a}}$. ed., São Paulo, Malheiros, 2004, p. 16.

47 Dentre os norte-americanos, cita os democrats $x$ constitutionalists; dentre os franceses, o embate entre a liberdade dos antigos x liberdade dos modernos e; dentre os alemães, os defensores do Rechsstaat x os defensores da Demokratie. J. J. Gomes De CANOTILHO, Estado de Direito, cit., p. 10. 
diferentes, não antagônicos, mas sim complementares: "uma é a legitimidade do direito, dos direitos fundamentais, do processo de legislação no Estado de Direito; outra é a legitimidade de uma ordem de domínio e da legitimação do exercício do poder político, no Estado democrático." O Estado de Direito, em sua concepção inicial, não atendia à necessidade da explicação da fonte do poder. A aplicação do principio da soberania popular em conformidade com as regras do direito é que transforma a essência do Estado de Direito em Estado Democrático de Direito, ao assegurar e garantir "o direito à igual participação na formação democrática da vontade popular", não havendo de se cogitar que a incorporação do elemento democrático afaste a força do direito, tampouco de se concluir que a observância aos ditames das normas jurídicas implique diminuição na força política e legitimadora do elemento democrático. Assim, conclui-se que o Estado Democrático de Direito possibilita a realização política de uma sociedade igualitária, sob a égide de uma Constituição e de leis legitimadoras de instituições políticas de fundo democrático, chegando J. J. Gomes de CANOTILHO a denominá-lo de Estado Constitucional Democrático de Direito ${ }^{48}$.

No arcabouço de princípios e regras da Constituição da República Federativa do Brasil, encontra-se a dimensão jurídico-constitucional nuclear do Estado Democrático de Direito. De forma expressa ou implícita nos princípios que alberga, seus artigos refletem os elementos essenciais do Estado Democrático de Direito, como por exemplo: o exercício do direito de voto, que é universal, igual, direito secreto e periódico (art.14); as formas de participação direta (art. 14, incisos); a descentralização do federalismo (arts.18 a 33); a independência dos magistrados (art. 95); o livre acesso à justiça (art. $5^{\circ}, \mathrm{XXXV}$ ); a ampla defesa e o contraditório (art. $5^{\circ}, \mathrm{LV}$ ); o devido processo legal (art. $\left.5^{\circ}, \mathrm{LIV}\right)$; o pluralismo político (art. $\left.1^{\circ} ., \mathrm{V}\right)$; o respeito às opiniões diversas; a garantia do debate e da negociação de interesses divergentes; o controle de constitucionalidade; o principio da legalidade da administração e a responsabilidade objetiva do Estado (art. 37); as liberdades (expressão, informação, entre outras do art. $5^{\circ}$.), que liberam o ser humano da opressão estatal e preservam sua dignidade; os mecanismos de garantia de direitos fundamentais, e ; as condições sócio-econômicas que possibilitam o pleno exercício dos direitos promulgados. Os mesmos elementos caracterizadores se encontram na Constituição da República portuguesa, que em seu artigo $2^{\circ}$., os apresenta, definindo o Estado de Direito Democrático como aquele "baseado na soberania popular, no

\footnotetext{
${ }^{48}$ J. J. Gomes De CANOTILHO, Estado de Direito, cit., p. 11.
} 
pluralismo de expressão e organização política democráticas, no respeito e na garantia de efetivação dos direitos e liberdades fundamentais, (...)". Em Conclusão: o Estado Democrático de Direito é mais do que um Estado de Direito e mais do que um Estado Democrático. Ele "é o Estado limitado pelo direito cujo poder político estatal é legitimado pelo povo" ${ }^{49}$, organizado e regido por uma Constituição.

Ao lado dos valores ou características do Estado Democrático de Direito supra listados caminham outros princípios que completam seu conteúdo: os princípios da igualdade, da justiça social, da separação de Poderes, da justiça social, da segurança jurídica e vários outros que se concretizam a partir de uma Constituição emanada do poder soberano popular. "O Estado Constitucional Democrático de Direito tornou-se um paradigma de organização e legitimação de uma ordem política”, o que significa, para J. J. Gomes de CANOTILHO, a rejeição de regimes totalitários. Conforme conclui o autor, a fórmula do Estado Democrático de Direito hodierno, "se revela como uma das mais adequadas" para consecução dos princípios e valores postos pela sociedade atual ${ }^{50}$.

\subsubsection{A democracia hodierna}

Hodiernamente, o conceito de democracia não se transmutou de forma a se afastar de seus elementos nucleares. Como nos ensina M.G. FerreIRA FilHo, a democracia é o governo da opinião pública ${ }^{51}$, o que de certo modo se assemelha à definição de GIOVANNI SARTORI, para quem a democracia é o sistema em que os governos atuam de acordo e com suporte na opinião pública, que consiste justamente na expressão da vontade do povo, que é o soberano no regime democrático. A definição de RoBERT ALAN DAHL não foge muito a essa linha, pois para o autor a democracia é a forma que permite a conformidade das expectativas da população à formulação política ${ }^{52}$.

${ }^{49}$ J. J. GOMES DE CANOTILHO, Estado de Direito, cit., p. 11.

${ }^{50}$ Para J. J. GOMES DE CANOTILHO essa formula é a do "Estado Constitucional de Direito Democrático e Social Ambientalmente Sustentado". Esse último elemento - a sustentabilidade ambiental - denota uma futura evolução a ser trilhada pelo Estado Democrático de Direito, que incorpora em seu rol a "nova dimensão' dos direitos fundamentais, ampliando o conceito de igualdade ao buscar garantir a todos a um ambiente sadio, bem como o direito das gerações futuras. Cf. Estado de Direito, cit., p. 7.

${ }^{51}$ M. G. FerreIRA FILHO, A democracia no limiar do século XXI, São Paulo, Saraiva, 2006, p. 145.

${ }^{52}$ R. A. DAHL, Poliarquia, trad. Celso Mauro Paciornik, São Paulo, EDUSP, 1997, p 25-31. Sobre o conceito de democracia, essas são as exatas palavras do autor: "Neste livro, gostaria de reservar o termo 'democracia' para um sistema político que tenha, como uma de suas características, a qualidade de ser inteiramente, ou quase inteiramente, responsivo a todos os cidadãos.” V. p. 25-26. Quanto ao conceito de 'poliarquia', explica o autor: "As poliarquias podem ser pensadas então como regimes relativamente (mas incompletamente) democratizados (...)". V. p. 31. Conforme M. G. FERREIRA FILHO, para Dahl, a democracia "designa uma 
A essência da democracia, para HANS KELSEN, está relacionada à forma de produção de normas. Para o autor,

"A democracia é simplesmente uma das técnicas possíveis de produção de normas de ordenação. Mas é uma técnica que tem características peculiares. Eliminadas as incrustações ideológicas, como as de soberania popular e representação, (...), a democracia moderna é o sistema de produção das normas de ordenação que confia a um corpo (Parlamento) eleito, com a base mais ampla possível (sufrágio universal) e com método eleitoral proporcional (mesmo sem pretensões de representação) que funciona, via de regra, segundo o princípio da maioria simples." 53

Em complemento ao conceito, continua o autor, demonstrando que

"A democracia, no plano da ideia, é uma forma de Estado e de sociedade em que a vontade geral, ou seja, sem tantas metáforas, a ordem social, é realizada por quem está submetido a esta ordem, isto é, o povo. Democracia significa a identidade entre governantes e governados, entre sujeito e objeto do poder, governo do povo sobre o povo." 54

Segundo H. KelSEN, "a democracia do Estado moderno é a democracia indireta, parlamentar, em que a vontade geral diretiva só é formada por uma maioria de eleitos pela maioria dos titulares dos direitos políticos”. A democracia direta, para o autor, não é mais uma forma possível de democracia, consideradas as dimensões que adquiriu o Estado. Os direitos políticos são exercidos na assembleia do povo ${ }^{55}$.

Para J. AfOnSo DA SILVA, o regime político democrático mantém seu núcleo básico no qual o poder se funda na vontade popular. O autor não apresenta uma única síntese do conceito de democracia, mas opta por colocar suas características essenciais, conceituando a democracia como "um processo de convivência social em que o poder emana do povo, há de ser exercido pelo povo, direta ou indiretamente, pelo povo e em proveito do povo" 56 . Além de denotar uma relação de poder político, é "um modo de vida”, ou seja, um conjunto de valores. Em suma, expressa sua síntese afirmando que

forma ideal, jamais atingida", enquanto a poliarquia significa o governo de muitos e trata-se de uma aproximação “imperfeita de tal ideal”. Cf. A democracia no limiar do século XXI, cit., p. 25.

${ }^{53}$ H. Kelsen, A Democracia, trad. I. Benedetti et alli, São Paulo, Martins Fontes, 2000, p. 13. Duas observações: 1) A democracia moderna referida por H. KELSEN corresponde à democracia ocidental da primeira metade do século XX; 2) A "produção de normas de orientação" está ligada ao processo normativo de produção de regras a orientar as condutas sociais.

${ }^{54}$ H. KELSEN, A Democracia, cit., p. 35. Para H. KELSEN, o povo corresponde a um conjunto dos detentores dos direitos políticos, sendo distintos daqueles que exercem tais direitos. "O 'povo' não é - ao contrário do que se concebe ingenuamente - um conjunto, um conglomerado, por assim dizer, de indivíduos, mas simplesmente um sistema de atos individuais, determinados pela ordem jurídica do Estado.” O Estado não é o povo, adverte H. KELSEN. Para mais detalhes sobre o conceito de "povo" para H. KELSEN, v. p. 36-37.

${ }_{55}^{5}$ H. KELSEN, A Democracia, cit., p. 43 e 46.

${ }^{56}$ J. AFONSO DA SILVA, Curso de direito constitucional positivo, cit., p. 126. 


\begin{abstract}
"A democracia, em verdade, repousa sobre dois princípios fundamentais ou primários, que lhe dão a essência conceitual: (a) o da soberania popular, segundo o qual o povo é a única fonte do poder, (...); (b) a participação, direta ou indireta, do povo no poder, para que este seja efetiva expressão da vontade popular; (...).",57
\end{abstract}

Sob o olhar de M. HeRman SAlem CAgGiano, a precisão conceitual da democracia demonstra-se extremamente complicada, pois se trata de uma categoria histórico-social evolutiva, que se transforma conforme as características peculiares de um povo ou uma nação, amoldando-se a essas. ${ }^{58}$ Apesar dessa complexidade, alguns pontos marcantes, frisados pela doutrina, são recorrentes. Os regimes democráticos, de acordo com a autora, apresentam inequivocamente suas exigências. Pode-se considerar que o conceito de democracia se constrói pelos seus elementos, a saber: o equilíbrio no exercício do poder, o pluralismo, o pluripartidarismo e a liberdade de associação, bem como a liberdade de exteriorização do pensamento e das idéias, a liberdade de reunião e a de pleitear cargos públicos. Para a autora, trata-se de uma fórmula política sensível e exigente, pois implica a preservação de diferentes fatores para sua implantação, manutenção e desenvolvimento. Para se detectar se em um determinado Estado é praticada a democracia e em qual grau, deve-se verificar a presença dos elementos supracitados, bem como averiguar-se o grau de competitividade na disputa do poder, o grau de participação social na sua Constituição, a existência de opções efetivas e a preservação de instrumentos de tutela e garantia dos direitos fundamentais.

Como a própria autora destaca, a democracia é uma forma política que até o presente não foi superada em termos práticos. Não se apresentou, até então, outra forma de organização do poder político no ambiente do Estado, que possa beneficiar a liberdade em tal grau. Trata-se de um verdadeiro mecanismo de preservação da liberdade individual, à medida que limita a tirania, o abuso do poder e marca a ascensão do povo ao poder. Em igual vetor, M.G. FERREIRA FILHO profere que não se encontra forma de governo melhor que a democracia, em que pesem todas suas limitações, que se traduzem, primordialmente, na dificuldade de concretizá-la, por causa da dependência de suas condicionantes $^{59}$. N. BOBBIO também reflete sobre o tema, afirmando que a democracia não está em crise, nem está à beira do túmulo, ao contrário do que muitos pensam ${ }^{60}$.

\footnotetext{
57 J. AfONSO DA SILVA, Curso de direito constitucional positivo, cit., p. 126-131.

58 M. Herman Salem Caggiano, Sistemas Eleitorais $x$ Representação Política, Tese de Doutorado apresentada à Faculdade de Direito da Universidade de São Paulo, 1987, p. 14. V. em especial a nota de rodapé n.14.

${ }^{59}$ M. G. FerReIRA FILHO, Democracia no limiar do século XXI, cit., p. XI.

${ }^{60}$ N. BobBIo, O futuro da democracia, cit., p. 19.
} 
Em sua teoria contemporânea, N. BOBBIO coloca a necessidade de serem observadas "as regras do jogo" ${ }^{61}$, pois são estas que diferenciam um regime democrático de seus opostos. O conteúdo de tais regras não difere essencialmente dos elementos anteriormente expostos ${ }^{62}$. Nas palavras do autor, por "um sistema democrático entende-se hoje preliminarmente um conjunto de regras procedimentais, das quais a regra da maioria é a principal, mas não a única, (...)" 63 . N. BoBBIO vai mais além, apresentando em sua teoria política contemporânea uma conceituação de democracia que ultrapassa os limites da ideologia. Um regime de governo é caracterizado por um conjunto de normas que apontam quem pode tomar as decisões e através de quais procedimentos. Esse poder de decisão pode ser atribuído a um, a poucos, a muitos e a todos os indivíduos, em teoria. Tendo característica democrática, tal poder decisório pertence a um "número muito elevado" ${ }^{64}$. Assim, surge o que o autor denomina de sua definição mínima de regime democrático: Um “conjunto de regras de procedimento para formação de decisões coletivas, em que está prevista e facilitada a participação mais ampla possível dos interessados".

Em que pese a regra fundamental da democracia ser, para N. BoBBIO, aquela da maioria, um terceiro elemento é acrescido à definição ${ }^{65}$. Para que uma maioria (ou um alto número de indivíduos), por meio de regras existentes, efetive o processo decisório de maneira democrática é necessária a liberdade de opinião, a possibilidade de escolha efetiva - além de outras liberdades derivadas - portanto, crucial a garantia dos direitos de liberdade.

\subsubsection{Condicionantes da democracia}

Retomando-se a premissa de que o melhor entendimento da democracia e da concepção do Estado Democrático de Direito permitirá delinear os reflexos da jurisprudência eleitoral e suas implicações, oportuno enveredar pelos ensinamentos de M.G. FERREIRA FILHO sobre as condicionantes da democracia. Dentre as principais

${ }^{61}$ As "regras do jogo" consistem, de modo resumido, na existência de um Poder Legislativo e de um Poder Executivo, ambos eleitos pelo povo. O voto deve ser universal, igual para eleitores e livre. Deve prevalecer o pluralismo de idéias e opções, além da realização de eleições conformes com o princípio da maioria. Cf. $\mathrm{N}$. Bоввіо, O futuro da democracia, cit., p. 77-78.

${ }^{62}$ Sobre os 'elementos' mencionados v. p. 35 desta dissertação.

${ }^{63} \mathrm{~N}$. BobBio, $O$ futuro da democracia, cit., p. 77-78. Para maior detalhamento sobre a regra da maioria e suas “aporias", v. Celso CAMPILONGO, Direito e Democracia, Max Limonad, 2a.ed, São Paulo, 2000.

${ }^{64}$ Atribuir a todos o poder leva apenas a um ideal-limite, para o autor. A chamada onicracia: uma forma onírica. Cf. N. BoBBio, O futuro da democracia, cit., p. 32.

${ }^{65}$ N. BobBio, O futuro da democracia, cit., p. 32. 
condicionantes atinentes ao presente tema, o mestre lista as sócio-econômicas, as culturaispolíticas, as institucionais, as instrumentais, bem como os pilares da democracia hodierna: os sistemas eleitoral, partidário e de governo.

Como profere o ilustre jurista, "se a democracia não prescinde de certo nível de desenvolvimento econômico, um alto nível de desenvolvimento não leva necessariamente à democracia" ${ }^{66}$. Como principais condicionantes sócio-econômicas da democracia, são apontados o pluralismo social, a desconcentração e dispersão dos fatores de poder e a ausência de desigualdades extremadas. Nisso, o pensamento do autor se assemelha ao de R. A. DAHL, para quem há uma forte relação entre desenvolvimento econômico e democracia ${ }^{67}$. Não haveria de ser diferente: é nítido, ao menos ao se considerar a realidade pátria, que o poder político é forma de aquisição do poder econômico. Esse é o fim individualista almejado por significativa parcela da classe que tem acesso ao poder político. A democracia social se funda na igualdade social e econômica, motivo pelo qual se vislumbra a correlação entre desenvolvimento e democracia, afora a percepção empírica apresentada nas democracias ocidentais. Se por um lado os direitos sociais têm trilhado nos últimos anos uma crescente potencialidade de concretização, o mesmo não se pode afirmar quanto aos direitos econômicos. Em que pese estarem previstos em algumas cartas constitucionais ocidentais, a igualdade econômica parece beirar a utopia, mesmo nas nações mais desenvolvidas. Isso decorre, de um lado, do modelo atual do capitalismo, que exige a maximização do lucro e, por consequência, a concentração da riqueza como forma de sobrevivência em um mundo globalmente competitivo. A proposta de realização efetiva das oportunidades a todos os cidadãos passa necessariamente por fatores financeiros e econômicos. Mais do que isso, a tentativa de se obter uma sociedade com igualdade de condições sociais e econômicas a todos os cidadãos é totalmente contrária a essência do capitalismo, que gera uma premência cada vez maior e mais acelerada da concentração da renda, como um buraco negro que suga com extrema força o que está ao seu entorno. Esta é da natureza do sistema capitalista, seu motor, sua mola propulsora. É a antonímia da distribuição das riquezas, sem a qual é difícil se imaginar uma sociedade socialmente justa, com plenas e iguais oportunidades a todos. Naturalmente não se está falando apenas de concentração de renda entre indivíduos, mas também entre nações. Se a riqueza não é condição suficiente para se obter um Estado

${ }^{66}$ M. G. FERREIRA FILHO, Democracia no limiar do século XXI, cit., p. 71

${ }^{67}$ R. A. DAHL, Poliarquia, cit., p. 75-90. Segundo o autor, “(...) apesar de o 'sucesso' econômico ser capaz de ameaçar as hegemonias gerando reivindicações pela liberalização política, o êxito econômico não tem ameaçado as poliarquias, mas o fracasso econômico, sim.” Cf. p. 89. 
Democrático em seu sentido maior - que inclui a igualdade sócio-econômica - tão pouco deixa de ser uma condição necessária. Atingir um real Estado Democrático sem maior equalização de riquezas é um obstáculo difícil de ser transposto. E para essa partilha se efetivar é necessário - mas não tão somente - que a riqueza exista em quantidade suficiente. ${ }^{68}$

Tomado o aspecto psico-cultural, a cultura do homem ocidental evidencia sua busca incessante pelo acúmulo monetário e pela obtenção do poder econômico como objetivo de vida e como forma de garantia do bem-estar individual, que se sobrepõe imensamente ao bem coletivo. Em raras situações, somente quando o bemestar individual é ameaçado é que se recorre à força da coletividade, não porque se anseie o bem estar geral como valor em si, que aparece quase como um valor altruístico, mas antes como forma de proteção ao indivíduo. Apesar das considerações soarem demasiadamente Hobbesianas, ao analisarmos os paradoxos inerentes ao modelo capitalista vigente, percebe-se - retomando a assertiva de M.G. FERREIRA FILHO - que ao mesmo tempo em que empiricamente se observa que o desenvolvimento proporciona melhores condições para uma democracia, este constitui, no modelo capitalista em vigor, uma barreira ao promover o acúmulo de renda por poucos, aumentando, assim, a desigualdade econômica e social.

Apesar disso, ainda reside razão ao professor, pois é de se considerar que os países desenvolvidos parecem ter melhores condições de efetivar os direitos fundamentais do que as nações assim denominadas de subdesenvolvidas, ainda que em ambos se encontre um Estado submetido ao Direito, com separação de Poderes e legalidade administrativa - as outras peças necessárias, descritas por E. DíAZ GARCíA ${ }^{69}$, para comporem um Estado de Direito. Reforça-se a ideia de que, além da proteção aos direitos fundamentais garantidas no ordenamento, os mecanismos sócio-econômicos requerem uma efetiva e honesta planificação de forma a atingirem uma efetiva realização material dos direitos fundamentais, sem a qual, os direitos não passarão de palavras. Aí reside uma importante diferença entre as nações verdadeiramente democráticas das formalmente democráticas.

\footnotetext{
${ }^{68}$ Não se esqueça da velha e fracassada teoria desenvolvimentista que propunha "fazer o bolo crescer, para depois dividir". Esteve fadada ao insucesso em sua primeira fase: fazer crescer. Pois o crescimento, nos países chamados subdesenvolvidos não foi viável em grau suficiente para acompanhar, de um lado o crescimento da população e, de outro, a constante tendência da concentração de riquezas que aumenta o número de desprovidos e desamparados. E ainda que lograsse sucesso com o crescimento, para fazer dividir ter-se-ia que imaginar outro modelo que não o atual adotado pelo capitalismo.

${ }^{69}$ Cf. E. DíAz GARCíA, Estado de derecho y sociedad democrática, cit, p. 29.
} 
Deixando-se a esfera estritamente econômica, mas sem perder de vista sua estreita correlação com a esfera social, tem-se que as condicionantes propriamente sociais, ou os "fatores sociais obstaculizantes" - empregando-se o exato termo de M.G. FERREIRA FILHO $^{70}$ - são aquelas que mais prejudicam a democracia. Três são as principais apontadas: 1) a questão das minorias sociais, cuja marginalização relega grande parcela da população à miséria; 2) o pretorianismo, que se transfigura em um regime totalitário, ao prever a interveniência das forças armadas no poder político; 3) a corrupção na forma de exercício do poder. M.G. FERREIRA FILHO discorre sobre a vital importância da moralidade pública para a estabilidade das instituições, mostrando que a corrupção é "particularmente grave numa democracia", em especial na representativa, na qual é confiada a um representante a realização do interesse geral. Ademais, a imoralidade no Poder leva à perda da legitimidade do regime, como bem observa o jurista. ${ }^{71}$ Ressalte-se que a corrupção não é privilégio das nações subdesenvolvidas, apesar de mais facilmente notadas nessas. A ausência de institucionalização política democraticamente eficiente com um sistema partidário eficaz e pautado na moralidade é apontada com uma das causas desse mal. Vide a corrupção eleitoral, que desmoraliza por completo a soberania popular do voto, que se desmancha perante a compra de votos e a troca de dinheiro por poder, que, por sua vez, trará mais dinheiro. A realidade recente deste país oferece alguns exemplos atuais de processos de decretação de perda do mandato de alguns dos Governadores eleitos em $2006^{72}$ pelo Tribunal Superior Eleitoral, sendo já decidido pela Corte Eleitoral a perda dos mandatos dos Governadores da Paraíba, do Maranhão e do Tocantins ${ }^{73}$.

${ }^{70}$ M. G. FerreIRA FILHO, Democracia no limiar do século XXI, cit., p. 76.

${ }^{71}$ M. G. FERREIRA FILHO, Democracia no limiar do século XXI, cit., p. 88.

${ }^{72}$ O Governador de Rondônia teve a perda de seu mandato decretado pelo TRE-RO em 04.11.08. O Tribunal julgou parcialmente procedentes a Ação de Investigação Judicial Eleitoral proposta pelo Ministério Público Eleitoral em face do Governador Ivo Narciso Cassol por captação ilícita de sufrágio e abuso de poder nas eleições de 2006. Cf. Assessoria de Comunicação Social do TRE-RO, TRE decreta perda de mandato de Governador e de Senador de Rondônia, 05.11.08, disponível (on line) in www.jusbrasil.com.br/noticias., [10.12.08]. Em novembro de 2009 o TSE havia suspenso o julgamento do recurso do Governador de Rondônia Ivo Cassol após pedido de vista do Min. Lewandowski. Cf. G1, Diego Abreu, TSE suspende julgamento de ação contra Ivo Cassol, 24.11.09, disponível (on line) in www.jusbrasil.com.br/noticias., [26.11.09]. Outros casos ainda em julgamento no TSE são o dos Governadores de Sergipe e de Roraima, ambos por abuso de poder político, econômico, compra de votos e fraude eleitoral nas eleições de 2006. Centro de divulgação da Justiça Eleitoral, disponível (on line) in http://tse.gov.br/sadAdmAgencia., [26.11.09].

${ }^{73}$ O Governador do Tocantins perdeu seu mandato por decisão do TSE (RCED N. 698) em 25.06.09, acusado de abuso de poder político nas eleições de 2006. Em abril do mesmo ano, o Governador do Maranhão Jackson Lago também perdeu o mandato pelos mesmos motivos. O primeiro Governador eleito em 2006 a perder o cargo foi Cassio Cunha Lima, da Paraíba. Centro de divulgação da Justiça Eleitoral, disponível (on line) in http://tse.gov.br/sadAdmAgencia., [26.11.09]. 
Associadas intimamente às condicionantes sociais estão as condicionantes culturais. A conduta e a mentalidade humana influenciam no plano político. A cultura política é reflexo da cultura geral, afetando as regras de convivência social e o funcionamento das instituições, como ensina M.G. Ferreira FILHO. O peso da cultura política no sucesso de um regime democrático pode ser analisado por diferentes ângulos. Em primeiro lugar, dela decorre a essência da legitimidade do poder governamental, ao fornecer a base ideológica para formação do entendimento do povo sobre o fenômeno do poder. Em segunda instância, a aceitação da participação igualitária de todos, seja no voto ou nas condições de elegibilidade, também influencia o êxito da democracia. Por fim, deve-se observar a atitude política dos cidadãos.

A respeito do primeiro aspecto, tem-se que a educação e os meios de comunicação são componentes basilares da formação da cultura política do cidadão. Se as instituições educacionais e a imprensa não se pautam por valores democráticos, desconsidera-se o reconhecimento das igualdades, fundamental ao se tomar a democracia sob o prisma do respeito ao próximo e para a qual a principal virtude é a sobreposição dos interesses gerais sobre os individuais. Recordando-se, para a formação da vontade geral visando à utilidade pública, como quis J. ROUSSEAU, são duas as condições apontadas por M.G. FERREIRA FILHO: a disponibilidade de informação honesta e suficiente para formação de opinião; a ausência da manipulação da vontade popular. Como profere o autor, um governo democrático deve educar seus cidadãos nessa virtude e não relegar a tarefa às religiões apenas. Compõem a formação do homem a difusão e o ensinamento dos valores democráticos na comunidade. A questão da formação do entendimento político do povo relaciona-se diretamente com a legitimidade dos governos à medida que esta última se perfaz no consentimento dos governados. O consentimento popular advém igualmente da experiência histórica e da influência de grupos ideológicos. Logo, a má ou ausente educação e informação afetam a qualidade desse consentimento ao prejudicar a formação de opinião do povo ou até ao permitir sua manipulação, enfraquecendo a legitimação do poder constituído.

No plano subsequente, para M.G. FERREIRA FILHO, a democracia hodierna se pauta pelo reconhecimento ou aceitação da igualdade de todos os homens com a consequente tolerância a pensamentos opostos, pilares base dos quais decorrem os elementos nucleares da democracia como já observado (pluralidade, diálogo, negociação, dignidade da pessoa humana e respeito à oposição). Tal visão é compatível com a 
poliarquia de R. A. DAHL, que se formula com a maximização da liberdade e da inclusão ${ }^{74}$. A liberdade se relaciona à liberdade de expressão e ao respeito às opiniões divergentes. A inclusão se aproxima da idéia de expansão da participação política.

Relativamente ao último aspecto, quanto à conduta política de um povo, embora as considerações de M.G. FERREIRA FILHO possam soar deterministas, quando o autor fala em "caráter nacional" ou "inclinações constantes de um povo", sua caracterização do brasileiro como "individualista" impõe um rótulo que não é privilégio nacional, pois a cultura humana - ocidental, ao menos - parece gozar da mesma qualificação. Contudo, de outro lado, o adjetivo também não descreve completamente o comportamento político do eleitorado pátrio, pois o elemento da apatia se configura como o mais marcante. Encaixa-se, portanto, com perfeição à classificação autoexplicativa feita por R. A. DAHL quanto à participação política dos cidadãos, que enfatiza o grau de apatia dos eleitores, tomando-os por "apolíticos", "políticos" (ou interessados), "participantes" e "poderosos" 75 . Certamente não se presencia no Brasil uma inclinação a uma participação ativa e persistente na política, o que reduz o êxito democrático e influencia a formação partidária e respectivos programas de governo, bem como na tolerância social quanto à falta de ética na política. Esse fator, como será oportunamente explanado, aparece contundentemente no voto dos Ministros que decidiram o assunto da fidelidade partidária.

Em conclusão, aliadas uma atitude política não participativa com uma má formação ou informação, o quadro resultante é uma redução significativa da qualidade da legitimação democrática.

\subsection{Representação política}

A obra de G. SARTORI, A teoria da representação no Estado representativo moderno ${ }^{76}$, completa meio século de existência demonstrando a atualidade

\footnotetext{
${ }^{74}$ Os termos empregados por R. A. DAHL são liberalization e inclusiveness, que, na versão traduzida da obra aparecem como poliarquia inclusiva e liberalização política. Cf. R. A. DAHL, Poliarquia, trad. Celso Mauro Paciornik, São Paulo, EDUSP, 1997, 75-90. Diz o autor: "Um relacionamento entre desenvolvimento socioeconômico e poliarquia inclusiva ou quase-inclusiva revela-se mais nitidamente, (...). Tal como nos regimes competitivos, também com a poliarquia: 'Quanto maior o nível socioeconômico de um país, maior a probabilidade de que seu regime seja uma poliarquia inclusiva ou uma quase-poliarquia. Se um regime é uma poliarquia, é mais provável que ele exista num país com nível de desenvolvimento socioeconômico relativamente alto do que num país de nível mais baixo." Cf. p. 77.

${ }^{75}$ M. G. FerReIRA FILHO, Democracia no limiar do século XXI, cit., p. 52.

${ }^{76}$ A obra original data de 1959. G. SARTORI, A teoria da representação no estado representativo moderno, trad. E. Gaetani e R. Gaetani, Revista Brasileira de Estudos Políticos, Universidade de Minas Gerais, 1962.
} 
de seu conteúdo, o que se revelará na análise dos votos proferidos em torno da questão da fidelidade partidária, bem como será componente necessário para se acompanhar os recentes julgados sobre matéria eleitoral. A interface de sua obra com temas atinentes ao direito eleitoral e à democracia é evidente e não passou despercebida ao autor, que afirma que os estudos eleitorais são os que "tocam mais de perto o problema da representação", desenvolvendo-se segundo diretrizes da sociologia e da ciência política ${ }^{77}$.

A representação política, seu modelo e modo de operacionalização se revestem de especial significado nos regimes democráticos, denotando sua condição de elemento essencial para a concretização da democracia. "A chave da democracia representativa é a representação", declara M.G. FERREIRA FILHO ${ }^{78}$. E não haveria de ser diferente, pois, nos regimes de governo ocidentais, a representação política funciona como a "mola-mestra da legitimação do exercício do poder político" 79 . O modelo institucional estabelecido e o modo de operação da representação política assumem vital relevância na constituição de regimes democráticos ao estabelecerem a "mecânica a viabilizar a operacionalização da democracia" ${ }^{80}$ e a aprimorar as instituições presentes em uma democracia representativa. Diante da óbvia impossibilidade prática do exercício do poder de forma direta, tal como pela reunião do povo nas ágoras, surgiu como uma necessidade da era moderna a fórmula da representação, que mostra a idéia da representação da comunidade junto ao pólo de poder, sendo, portanto, a única encontrada para operacionalizar o alargamento paulatino da participação popular ${ }^{81}$ e realizar as concessões necessárias para a pacificação social e a manutenção do status quo. A representação, conforme ressaltou CARL FRIEDRICH, é um dos aspectos básicos do governo moderno ${ }^{82}$.

Observa-se na história política que, em maior parcela, os governos não se legitimam por procedimentos eletivos, tal como ocorre nos autoritários ou ainda, remontando-se à Idade Média, na qual o monarca tinha seu poder legitimado por ser o representante de Deus, professor da vontade divina. Sendo a legitimação popular, por sua vez, o elemento nuclear do Estado Democrático de Direito, busca-se maior compreensão do fenômeno da representação política neste item.

\footnotetext{
${ }_{77}^{7}$ G. SARTORI, A teoria da representação no estado representativo moderno, cit., p. 46-89.

${ }^{78}$ M. G. FERREIRA FILHO, Curso de Direito Constitucional, cit., p. 86.

${ }^{79}$ M. Herman Salem Caggiano, Sistemas Eleitorais x Representação Política, cit., p.9.

${ }^{80}$ M. Herman SAlem CAGgiano, Sistemas Eleitorais $x$ Representação Política, cit., p.2.

81 Como anteriormente explanado, adota-se aqui o princípio segundo o qual as Revoluções Liberais introduziram os governos representativos e não uma produção democrática, que somente viria de fato com a extensão do voto.

${ }^{82}$ C. FRIEDRICH, Gobierno constitucional y democracia, vol. II, Madrid, Instituto de Estudios Politicos, 1975, p. 11.
} 


\subsubsection{Conceito}

Do entendimento comum que se tem do instituto é possível extrair-se uma definição singela de representação política. A etimologia da palavra representação possui o significado de "apresentar de novo" ou de "tornar presente alguma coisa ou alguém que não está presente". A impossibilidade de comparecimento ou participação se resolve na indicação de um representante, cuja tarefa é fazer valer os interesses do representado. Em matéria política, coloca G. SARTORI, a representação se transfigura em um "corpo restrito, que está para a coletividade, assim como uma carta geográfica está para o território que o representa", configurando claramente o aspecto da "representatividade". Em um segundo significado, surge a questão da "responsabilidade", ou seja, há uma obrigação do representante em responder ou prestar contas ao representado ausente. Ambas se perfazem simultaneamente na figura da representação. Deste modo, o representante político exercerá as funções governamentais em nome daqueles cujos interesses defenderá.

M.G. FERREIRA FILHO expõe a idéia de um vínculo entre governantes e governados que estabelece um compromisso no qual os primeiros devem agir em nome dos segundos, com vistas ao bem dos representados ${ }^{83}$. Apreciando com maior profundidade o instituto, M. HERMAN SALEM CAGGIANO ${ }^{84}$ o caracteriza como um sistema, configurando-se em um verdadeiro arranjo político, constitucionalmente consagrado (desde os tempos modernos) e que estabelece a eleição dos governantes a representar o corpo social. A complexidade desse arranjo afasta os representados das decisões diretas que afetam a sociedade, bem como da gestão da coisa pública, uma vez que estas estão delegadas aos intermediários. A oportunidade de manifestação de vontade do governado se restringe, assim, aos momentos determinados pelo processo eleitoral.

O fato novel do citado arranjo institucional é justamente o elemento diferenciador dos sistemas de escolha direta, transfigurando-se no deslocamento do pólo do exercício do poder político do povo para um organismo de caráter abstrato em conformidade com as normas do ordenamento jurídico que conferem a tal órgão mormente, a um Parlamento - a tarefa de exercer o poder político, preservando seus detentores originais o poder de seleção dos representantes que o comporão. Essa

\footnotetext{
${ }^{83}$ M. G. FERreira FILHO, Curso de Direito Constitucional, cit., p. 87-88.

${ }^{84}$ M. Herman Salem CagGiano, Sistemas Eleitorais x Representação Política, cit., p.18-19.
} 
transmutação caracteriza o processo de institucionalização que marca as sociedades politicamente organizadas e, no caso brasileiro, apresenta seus contornos claramente definidos na Carta Magna em vigência. O direito de participação política do pólo decisional é expresso pelo direito de sufrágio. O pronunciamento do povo se dá pela seleção de seus representantes e o povo terá nova oportunidade de manifestação somente nas próximas eleições, quando exercerá seu direito de não reeleger os representantes que não satisfizeram suas expectativas ${ }^{85}{ }^{86}$. Porém, é fato que não há representação, na democracia, que se processe fora das eleições, pois só estas que legitimam o poder. Representam o momento da passagem, da outorga do poder soberano do povo para seus representantes, que assumem a tarefa de tomar as decisões políticas no lugar do povo, por meio do processo legislativo.

\subsubsection{Natureza da representação política}

Desvendar a essência da representação política é uma das mais árduas tarefas do Direito Público e da Ciência Política. Seu principal problema é identificar a natureza da relação representado/representante, conforme professa M.G. FERREIRA FILHO $^{87}$.

As teorias que versam sobre a representação política procuram delinear o fundamento da legitimidade do poder, demonstrando a que título se detém e de que modo se exerce o poder, indagando quem são os representados e os representantes no mecanismo de escolha via eleitoral. Em outras palavras, diversas teorias surgiram para explicar a natureza dessa representação e o papel dos sujeitos que a performam.

Com esse intuito, a doutrina busca revelar a natureza do instituto através da análise do mandato eletivo, estudo esse que passa pela observação dos diferentes formatos que o mandato adquiriu ao longo da história, fruto da ideologia prevalecente e do poder dominante e consequência das pressões sociais de cada época. Por essa razão, a

\footnotetext{
${ }^{85}$ Excetua-se aqui a existência do instituto do recall, inexistente no ordenamento pátrio.

${ }^{86}$ Pelo fato do povo somente ter a oportunidade de exercer seu poder soberano por ocasião das eleições, ficando, durante a legislatura, à mercê das intenções de seus representantes e somente podendo agir no próximo pleito eleitoral, é que S. RESENDE DE BARROS fala em um "Estado Eleitoral de Direito". Cf. Contribuição dialética para o constitucionalismo, cit., p. 73 e aula proferida em 15.08.07 no curso de pósgraduação da Faculdade de Direito da Universidade de São Paulo.

${ }^{87}$ Nos exatos termos do mestre, o problema da representação se configura em explicar "qual é a natureza dessa ligação entre povo e representante, entre eleitor e eleito, entre o que escolhe, mas obedece e o que é escolhido, porém manda?”. Cf. M. G. FERREIRA FILHO, Curso de Direito Constitucional, cit., p. 86-87.
} 
exposição das teorias que versam sobre a natureza da representação política se faz a partir da cronologia evolutiva das instituições políticas, cuidando de detalhar a forma que o mandato assume conforme os fundamentos que o amoldam e o momento social e histórico que o determinam. Em suma, a exposição das teorias sobre a natureza da representação política é essencial para o entendimento da natureza do mandato. Como será assinalado quando da análise dos pronunciamentos das cortes superiores, a respeito da questão da fidelidade partidária, a perfeita compreensão da teoria da representação política será ponto crucial no deslinde das questões partidárias. M. Herman SALEm CAGGiano aponta diversas teorias que buscam desvendar o núcleo do mandato representativo, entre as quais se podem citar como principais: a teoria do mandato privatístico ou tese da representação fracionada; a teoria da nação; a teoria do órgão, e; a teoria da investidura ${ }^{88}$. Em termos cronológicos, a primeira foi superada pela segunda e as demais se apresentaram como alternativas a essa, como se poderá visualizar a seguir.

A origem do instituto da representação se encontra na história medieval inglesa, particularmente na evolução de suas instituições políticas a partir do século XII ${ }^{89}$ por meio de formações consultivas que ditavam os contornos de conselhos feudais e de cuja moldagem se extraía a presença de uma vinculação entre os representantes e os representados, sendo os primeiros meros mandatários. Possuía, então, o mandato um sentido imperativo ou vinculativo, muito similar ao instituto do mandato civil, no qual o mandatário se atém às instruções dos mandantes, revelando seus atributos de imperatividade e vinculação do representante à vontade do representado. Tais elementos configuram, conforme assevera M. HERMAn SALEM CAGgiAnO, a tese da representação fracionada, na qual "cada cidadão se faz detentor de uma parcela ideal do mandato conferido ao eleito" ${ }^{90}$. Com esses traços se delineava o Parlamento inglês medieval, em composição bicameral agregada à figura do monarca para formar a instância decisória política governamental, cujas características perduraram até o período setecentista, quando ainda se considerava os parlamentares como mandatários dos eleitores, por consequência da fragmentação do poder estatal, regionalmente estabelecido.

\footnotetext{
${ }^{88}$ M. Herman SAlem Caggiano, Sistemas Eleitorais x Representação Política, cit., p. 20-26.

${ }^{89}$ No século XII o maior exemplo desse tipo de instituição é o Magnum Conciluim, composto por prelados e senhores feudais, constutuindo o Conselho Comum do Rei. No século seguinte, tal conselho é de fato institucionalizado por meio da Magna Carta (1215), cuja evolução amoldou a assembleia em configurações parlamentares, resultando, em 1351, na bicameralidade do Parlamento inglês a congregar representantes dos condados na Câmara dos Comuns. Cf. M. HeRman SAlem CAGgiano, Direto Parlamentar e Direito Eleitoral, cit., p. 7 a 12.

${ }^{90}$ M. HeRman Salem Caggiano, Sistemas Eleitorais $x$ Representação Política, cit., p. 20.
} 
O respaldo nos atributos do mandato civil veio a ser superado no século XVIII com o liberalismo e a formação dos Estados. Destaca-se a teoria da representação da nação ou tese da soberania nacional, formulada pelo abade Sieyès, para quem o mandato é outorgado à nação, pois ela detém a soberania. Esse descolamento da moderna representação política de suas origens privatísticas se concretizou com a Constituição francesa de 1791, a partir da noção de que os representantes nomeados nos departamentos não serão representantes de um determinado departamento, mas da nação inteira ${ }^{91}$, reflexo do artigo $3^{\circ}$. da Declaração dos Direitos do Homem e do Cidadão, publicada dois anos antes, que apontava que "o princípio de toda a soberania reside essencialmente na nação". Enfatiza G. SARTORI que a referência à nação traz um novo conceito da representação política, que constrói a figura do mandato representativo ou mandato de representação da nação: um mandato livre, que permite ao representante deliberar livremente conforme sua consciência, não estando atrelado à vontade de quem o elegeu. ${ }^{92}$

A nação, entidade abstrata, representa a coletividade dos indivíduos que a formam, mas é distinto desses. Com isso, o representante deverá decidir conforme os interesses maiores da nação e de acordo com sua própria consciência e não se submeter aos interesses de grupos ou de indivíduos que o elegeram. Há, pois, uma desvinculação do mandato representativo do grupo que o outorgou. O princípio da representação se desvencilha do medieval na passagem do mandato imperativo para seguir a fórmula da representação e soberania da nação, proporcionando o nascimento das instituições representativas, principalmente o Parlamento representativo, para o qual se estabelecia que os deputados não mais representariam os eleitores, mas a entidade "nação". Conforme a assertiva de M.G. FERREIRA FILHO, o povo, ao exercer seu direito de voto, o faz como órgão da nação para a escolha dos representantes desta. Segundo o mestre, "essa teoria resulta na soberania do Parlamento" e desvincula a responsabilidade do eleito aos

\footnotetext{
${ }^{91}$ G. SARTORI, A teoria da representação no estado representativo moderno, cit., p. 19. O autor observa que a constatação de que "os representantes não devem ser mandatários", mas sim representar antes que seus mandantes, a nação, já constava no discurso de Edmund Burke (datado de 1774) e outros escritos ingleses que antecederam o texto constitucional francês tido como o introdutor do conceito publicista de representação. V. p. 22-25. Em diferente visão da de Burke, C. FRIEDRICH aponta a natureza dual da representação política. Para o autor, "um Parlamento es ambas cosas: uma asamblea deliberante de uma nación, com un solo interés, el del conjunto, y un congreso de embajadores con intereses distintos y hostiles." C. FRIEDRICH, Gobierno constitucional y democracia, cit., p. 22.

${ }^{92}$ Cf. M. Herman Salem Caggiano, Sistemas Eleitorais x Representação Política, cit., p. 23. V. também G. LEIBHÖLZ, La Rappresentazione nella Democrazia, Giufrrè Editore, Milão, 1989, p. 303-405. De acordo com G. LEIBHÖLZ, o mandato imperativo é contrário à essência da representação, uma vez que o indivíduo que tomou a decisão política pela sociedade somente será considerado o representante desta se sua manifestação de vontade foi livre.
} 
eleitores ${ }^{93}$. Apesar do caráter livre e desvinculado do mandato representativo, como lembra GERHARD LEIBHÖLZ, a partir do Estado Constitucional, a competência dos órgãos representativos estatais estavam limitadas ao conteúdo da Constituição. Portanto, a liberdade da decisão do representante não se transformaria em arbitrariedade, pois os limites constitucionais definiram o campo discricionário de sua atuação ${ }^{94}$.

\subsubsection{O Parlamento e a representação política}

Oportuno nesse momento discorrer sobre a importância do papel do Parlamento na transformação da figura do mandato, verificando-se como essa peça se encaixa no quebra-cabeça político do final século XVIII e como se compatibilizou com as teorias da representação política. Porém, sua relevância não advém apenas do exposto, mas principalmente por possibilitar a concretização do mecanismo da representação ${ }^{95}$.

Conforme ensina M. Herman SAlem Caggiano, a instituição parlamentar corresponde a uma das aspirações do ideal democrático, ao fornecer aos representantes escolhidos pelo povo o poder da decisão política. As Constituições ocidentais conferem extrema relevância aos Parlamentos que se configuram como sendo o locus de atuação dos representantes populares, uma assembleia de deliberação composta pelos eleitos que decidem em nome da sociedade, com fundamento no princípio representativo. Recorda a autora que há uma a conexão íntima entre a evolução das instituições políticas e da representação política com a trajetória histórica do Parlamento ${ }^{96}$, ressaltando a constante presença deste na política mundial, o que se observa, principalmente, em função de sua natureza representativa. Ademais, os processos de redemocratização hodiernamente observados apresentam, com frequência, em sua gênese, a formação de um novo Parlamento por meio de eleições. Necessário, pela importância ora delineada, deter-se, por um instante, no aprofundamento de suas funções visando

${ }^{93}$ M. G. FERreira FILHO, Curso de Direito Constitucional, cit., p. 87.

94 G. LeIBHÖLZ, La Rappresentazione nella Democrazia, cit, p. 303-405. O autor assevera que em toda Constituição liberal, ao se remeter ao sistema representativo, a consciência é definida como o único critério no qual o deputado deve orientar sua decisão, o que garante a legitimidade das decisões políticas que os representantes devem tomar.

95 H. KELSEN situa o Parlamento como a forma política dos séculos XIX e XX, afirmando que o parlamentarismo "podia indubitavelmente reclamar para seu ativo resultados realmente importantes, tais como a emancipação completa da classe burguesa mediante a supressão dos privilégios" e "em seguida, o reconhecimento da igualdade dos direitos políticos do proletariado”. H. KELSEN, A Democracia, cit., p. 45.

96 "Essa lenta, porém contínua, trajetória preordena a idéia vetorial a acompanhar a formatação dos Parlamentos até nossos dias, no sentido de identificá-los como cenários a albergar os representantes do povo". Cf. M. HeRman SAlem CAgGiano, Direto Parlamentar e Direito Eleitoral, cit., p. 8. 
compreender o papel dos detentores de cargos eletivos parlamentares e o modo pelo qual suas funções se desempenham.

O Parlamento, segundo H. KELSEN ${ }^{97}$, é o órgão colegial eleito incumbido da formação da vontade diretiva do Estado. Na democracia, ele é eleito pelo povo, com base no sufrágio igualitário e universal. Os elementos que compõem o núcleo do conceito de Parlamento ${ }^{98}$ o caracterizam por suas funções e o descrevem como uma assembleia. Frisa M. Herman SAlem Caggiano que o Parlamento guarda similaridade com as assembleias por se constituir a partir da reunião de pessoas com a função de debater temas de interesse coletivo. Além de seu caráter de órgão colegiado, em sua essência é que se encontra o discrímen: o Parlamento se funda no princípio representativo. Somam-se a esse elemento as seguintes peculiaridades: um intrincado processo deliberativo, que visa culminar na tomada de decisões, e; o instituto da responsabilidade política, que no modelo dos sistemas parlamentaristas, permite a escolha do chefe de governo por decisão parlamentar e avaliação constante de seu desempenho.

O Parlamento, com a função de positivar o direito, atende à vontade soberana e assume uma posição de superioridade perante os outros Poderes na era oitocentista. Seus componentes exercem uma função pública, estatal, podendo deliberar livremente, de acordo com os interesses da nação, segundo a teoria vigente à época de seu surgimento. Percebe-se assim, que há uma desvinculação do mandato. A partir desse momento, passa a ser possível se cogitar de um mandato livre (freies mandat).

H. KELSEN, comentando a tentativa de compatibilização da ideia de liberdade democrática com a impossibilidade do exercício pelo povo diretamente da formação da vontade do Estado, retoma a teoria da ficção da representação, pela qual o Parlamento "é apenas um representante do povo", e, de outra face, "o povo pode exprimir sua própria vontade apenas no Parlamento e através dele (...)”. Ressalta H. KELSEN que, apesar da expressão da vontade popular se processar por meio do Parlamento, vigora "exclusivamente a regra de que os deputados não podem receber instruções obrigatórias dos próprios eleitores, o que torna o Parlamento, no exercício de suas funções, juridicamente independente do povo" 99 . Este fato marcante se revela igualmente no clássico pensamento de Burke sobre os ideais que justificam a representação política

\footnotetext{
${ }^{97}$ H. Kelsen, A Democracia, cit., p. 46.

98 Adota-se para esse estudo o termo "Parlamento" em seu sentido mais amplo, como órgão de representação popular, que têm como sinônimos Congresso Nacional ou Assembleias Legislativas, como é o caso brasileiro.

${ }^{99}$ H. Kelsen, A Democracia, cit., p. 48.
} 
moderna, segundo os quais o Parlamento não se definia como "um congresso de embaixadores de interesses opostos e hostis", que se tutelam como "agente e advogado" contra seus semelhantes, mas sim uma "assembleia deliberante de uma nação, com um único interesse, o de todos" ${ }^{100}$. Na medida em que o Parlamento assumia diversas funções estatais, acrescendo-lhe poder, sua composição inicial - a de um corpo de embaixadores acreditados junto ao monarca - perde o sentido. Essa transmutação, que pôs termo ao mandato imperativo, pode ser observada do prisma das instituições representativas do Estado. Se antes o corpo representativo se formava buscando o controle do poder do Estado, configurando-se em um organismo externo a este, passa o Parlamento a ser um órgão internalizado pelo Estado, que não mais busca tratar "com o Estado" para fazer valer os interesses de seus representados, como se procedia na representação de modelo privado, mas agora representa o próprio Estado (nação). Tal fato se reveste de extrema significância pelas profundas mudanças que proporcionou. Primeiramente, o poder que era do Estado e se concentrava no monarca passa à assembleia representativa, que ao mesmo tempo em que se associa ao poder, representa o Estado. Em outro plano, os representantes, ao deixar de representar os interesses dos mandantes para representar os interesses da nação, recebem a função não somente de tutela dos representados, mas igualmente de governo dos mesmos. O Parlamento se torna um órgão do Estado e por essa razão o representa.

A função representativa do Parlamento aparece como uma de suas tarefas preliminares, arvorando as demais funções parlamentares. A atribuição legislativa originária do Parlamento era justamente a de concretizar o instituto da representação, inicialmente com tarefas consultivas, assemelhando-se a um conselho. Evoluiu no sentido de assumir a característica de assembleia parlamentar, instaurando um processo de debates e deliberações, elemento que, como visto, será essencial para formar os primeiros embriões democráticos, posteriormente, quando da adição de componentes que permitirão a diversidade de opiniões e a oposição política no âmbito parlamentar. Essa relevante atuação no sentido de se tornar um canal de comunicação com a sociedade, que por si é representada, promovendo debates que resultam em suas deliberações, proporciona ao Parlamento visibilidade e notoriedade para suas atribuições. O processo de debates tem como produto fim a elaboração de leis que resumem a vontade dos representados. Em

${ }^{100}$ Discurso de E. Burke trazido por G. SARTORI, A teoria da representação no estado representativo moderno, cit., p. 26-27. C. FRIEDRICH, em oposição à Burke, afirma que o Parlamento é sim um congresso de embaixadores com interesses próprios, opostos e hostis que convivem lado a lado com a representação dos interesses da nação, dando o caráter dual do Parlamento. C. FRIEDRICH, Gobierno constitucional y democracia, cit, p. 22. 
consonância com a teoria da representação, a lei é o espelho da vontade geral. Por assim se considerar, a lei é o reflexo da representação e de sua qualidade democrática. Os representantes elaboram a lei através de um processo deliberante, que conduz a decisões políticas resultantes de compromissos mais eficazes, segundo G. SARTORI ${ }^{101}$. A atividade deliberante do Parlamento é coordenada para ajustar posicionamentos conflitantes.

Deste modo, o alargamento funcional parlamentar apresenta novo capítulo à medida que às funções deliberantes originais do Parlamento inglês veio se somar a tarefa legiferante, entendida estritamente como a função de produção de leis. Esta, de sua feita, tem no mecanismo de deliberação a principal fase do processo legislativo. Seu produto consiste em um resultado conclusivo: a decisão política. Trata-se, portanto, a função legislativa, de uma tarefa-poder, ao concentrar na mão dos componentes a capacidade de determinação da conduta dos cidadãos. Em adição, observa-se também que o poder privativo de legislar lhe garantia o poder de tributar, para o qual se exige lei para inauguração de tributos. Mas o acúmulo de funções e de consequente poder se estendia igualmente à seara da definição, do controle e fiscalização das atividades financeiras e orçamentárias operadas pelo Poder Executivo. Hodiernamente, o papel parlamentar de controle político assumiu especial relevância, refletido na fiscalização da eficácia das políticas públicas e na eficiência da aplicação dos recursos públicos, desenhando-lhe a figura do fiscal da atividade governamental. Toda essa valoração se perfaz e se legitima com fundamento na representação popular. Ora, são os representantes do povo os guardiões e os julgadores da utilização dos recursos públicos captados por impostos, dotados de poder de polícia para requerer de autoridades informações e esclarecimentos que podem resultar, inclusive, na perda de cargos eletivos, além de outras penalidades legalmente previstas.

A função eleitoral do Parlamento advém de duas fontes. A primeira se denota do poder de controle que o Legislativo detém sobre o governo. A segunda, em íntima complementaridade com a função representativa, que se traduz na "atividade

${ }^{101}$ G. SARTORI, A teoria da representação no estado representativo moderno, cit., p. 26-34. De acordo com M. HERMAN SALEM CAGGIANO, não é a toa que, para o autor, reside nesse fato a maior virtude da democracia representativa em relação às formas de participação diretas (ou democracias participativas). O ponto é exatamente a falta do processo de discussão e deliberação que restam ausentes em procedimentos como plebiscito ou referendo nos quais o povo decide sem oportunidade de debate, por vezes sem informação ou ainda por obrigação. Elementos que foram analisados ao discorrer sobre a cultura política como condicionante da democracia. Cf. M. Herman SAlem CAggiano, Direto Parlamentar e Direito Eleitoral, cit., p.18. 
efetivamente eleitoral" - nos termos de M. Herman SAlem CAgGiano - "ao colocar o Parlamento como substituto do povo na seleção de seus representantes/governantes." 102

Do exposto se extrai o porquê da época áurea do Legislativo, que se sobrepunha aos demais Poderes. Tamanha concentração de poder havia de ser restringida. Como contraponto, amenizando o soberbo poder parlamentar, a doutrina da separação dos Poderes buscou o equilíbrio e a limitação do poder, estabelecendo o mecanismo de freios e contrapesos, adotando a concepção clássica de C. MONTESQUIEU.

\subsubsection{Eleições e representação política}

Nos primórdios da representação política, observa-se que não necessariamente o representante era escolhido pelo representado, a exemplo do rei, que fundava seu poder na "escolha" divina. Como bem recorda M.G. FERREIRA FILHO, a representação é anterior à democracia moderna ${ }^{103}$. A própria Constituição Francesa de 1791 estabeleceu que o monarca representava a nação. G. SARTORI elabora uma complexa construção para analisar se a eleição é elemento necessário à representação ${ }^{104}$. Para tanto, apresenta doutrinas diversas e opostas, cujo conteúdo se assemelha às listadas por M. HERMAN SALEM CAGGIANO ${ }^{105}$. Pela teoria da omni-representatividade, como assim o autor denomina, com base nas Constituições do século XX e na Constituição francesa de 1791, extrai-se a conclusão de que também órgãos não eletivos são representativos. Não apenas a assembleia eletiva era representativa: o monarca soberano, a Câmara Alta, o Judiciário, são enfim, provas de que a representação não seria determinada pela existência de procedimentos de escolha via eleição. Tal natureza representativa de todos os órgãos do Estado advinha do princípio contido na Declaração de Direitos do Homem e do Cidadão que, em seu artigo $3^{\circ}$., previa que toda autoridade decorria expressamente da nação. Decorre desse artigo a máxima de que todo órgão do Estado representa a nação e que, consequentemente, forma diversa seria ilegítima. Assim, a legitimidade no Estado de Direito Liberal se funda no princípio representativo, que por sua vez, estava atrelado à

\footnotetext{
${ }^{102}$ Cf. M. Herman Salem Caggiano, Direto Parlamentar e Direito Eleitoral, cit., p. 25.

${ }^{103}$ M. G. FERREIRA FILHO, Curso de Direito Constitucional, cit., p. 86.

${ }^{104}$ G. SARTORI, A teoria da representação no estado representativo moderno, cit., p. 40 a 52.

${ }^{105}$ M. Herman Salem Caggiano, Sistemas Eleitorais x Representação Política, cit., p. 20-26.
} 
teoria da nação. De tal raciocínio, mostra G. SARTORI que é possível se considerar a equação "Estado Moderno igual a Estado Representativo" 106.

Porém, adverte o autor, que a oposição extrema às conclusões expostas pela teoria da omni-representatividade levariam ao pólo contrário, no qual nenhum estado seria representativo. Bastaria, para tanto, amputar o órgão eletivo do Estado Moderno mormente a Câmara baixa ou ambas - que a "equação tornar-se-á gratuita e arbitrária". Outras teorias surgiram em ataque às respostas não fornecidas pela teoria da soberania da nação. A teoria da investidura se insurge contra o fundamento da delegação presente nas outras teorias da representação, procurando demonstrar, a partir da diferença entre os conceitos de nação e governo, que resta afastada a idéia de transmissão do poder de um polo a outro, característica da delegação. Como bem traduz M.G. FerREIRA FILHO, para tal doutrina, o representante não recebe do povo um mandato propriamente dito, o que se infere da própria proibição do mandato imperativo. A solução aparece ao se desvendar o fenômeno da investidura, segundo o qual o poder do governante é adquirido ao receber a função pública na qual se investirá, exercendo-a a partir de uma atribuição de competência, estando, portanto, desvinculado da vontade daqueles que o elegeram para assumir tal função pública. Como observam M.G. Ferreira Filho e M. Herman SAlem CagGiano, para essa doutrina, o processo eleitoral se reduz a um instrumento de atribuição de competência, tendo como ator principal o representante, investido do poder de querer pelo todo, sem nada a vincular sua atuação, juridicamente, à vontade dos eleitores ${ }^{107}$.

Para G. SARTORI, nenhuma das doutrinas acima expostas trouxe a resposta almejada para desvendar a representação política. A falha delas está, para o autor italiano, na generalização do conceito de representação. Ao se generalizar, "o conceito de representação acaba por perder todo conteúdo específico", devendo-se lhe atribuir um significado que extrapole a equação "representação é igual à atividade exercida no interesse público" ${ }^{108}$. G. SARTORI parece caminhar para uma posição intermediária entre os extremos. Mas, de fato, o que faz é adicionar novos elementos para análise do conteúdo da representação. Primeiramente, recupera a essência da doutrina da representação, pontuando que seu principal objetivo é mostrar o modo pelo qual o poder é exercido e o fundamento de sua legitimidade. Está, portanto, atrelada à relação governantesgovernados. Por serem os representantes os justos formuladores das normas jurídicas não

\footnotetext{
${ }^{106}$ G. SARTORI, A teoria da representação no estado representativo moderno, cit., p. 44.

107 M. Herman Salem Caggiano, Sistemas Eleitorais x Representação Política, cit., p. 20-26; M. G. FERREIRA FILHO, Curso de Direito Constitucional, cit., p. 85-89.

${ }^{108}$ G. SARTORI, A teoria da representação no estado representativo moderno, cit., p. 40-53.
} 
cabe a estes decidirem o modo para constituir esta mesma representação, de onde se infere que o problema deve ser examinado em termos eleitorais. Contudo, se a representação não prescinde de um conteúdo específico atrelado ao elemento eleitoral, a investidura eleitoral não é suficiente para determinar o conteúdo da representação ${ }^{109}$. Afirma categoricamente o autor que "sem eleição pode-se também obter representatividade". E a solução que encontra para o dilema reside exatamente em separar o conteúdo da representação em representatividade e responsabilidade. A tarefa da teoria da representação não se resume em explicar como um órgão estatal retrata a coletividade, mas igualmente de mostrar como os órgãos estatais respondem de cima para baixo. Tendo esses dois elementos representatividade e responsabilidade - conjugados na formação do conteúdo da representação, sua doutrina, segundo o autor, "fica ligada indissoluvelmente à doutrina democrática, isto é, torna-se a doutrina da 'representação eletiva"”, cuja missão é demonstrar a obrigação dos representantes legitimados prestarem contas aos governados ${ }^{110}$.

De outra face, é errado concluir que as eleições são apenas um meio de designação de dirigentes. O essencial é estabelecer como governarão, para quais objetivos será orientado o exercício do poder. As eleições são mais que um ato de nomeação. São um poder, recorrente, sendo exercido, que permite confirmar ou não, em certa frequência, se um dirigente continua a ser representante. Um poder sendo exercido sobre o representante. Em teoria, o caráter periódico das eleições obriga o eleito a um comportamento de responsabilidade ${ }^{111}$.

Em que pese demonstrado que as eleições são o único meio de garantir a correspondência de governo com governados, persiste o problema da teoria da representação, pois "o fato de que os legisladores são eleitos não significa que eles 'representem"”, denotando falha no aspecto específico da representatividade ${ }^{112}$. A doutrina alemã pretendeu solucioná-lo com a teoria do órgão, segundo a qual o órgão é a coletividade organizada para querer, produzindo em si próprio a vontade que exprime. $\mathrm{O}$ Parlamento seria o órgão da nação formado por representantes que exprimem sua vontade. A falácia dessa teoria apontada por G. SARTORI reside no fato de que, o Parlamento alemão

\footnotetext{
${ }^{109}$ G. SARTORI traz o exemplo do Papa, líder da Igreja católica, onde o fato de ser eleito por um colegiado não implica que o Sumo Pontífice os represente. De outro lado, o autor faz referência à doutrina angloamericana, para quem a teoria das eleições ou teoria 'elcionística' é a essência do próprio conceito de representação. V. G. SARTORI, A teoria da representação no estado representativo moderno, cit., p. 48-53.

${ }^{110} \mathrm{G}$. SARTORI, A teoria da representação no estado representativo moderno, cit., p. 48-53.

${ }^{111}$ G. SARTORI, A teoria da representação no estado representativo moderno, cit., p. 76-78. Ao examinar as decisões dos Tribunais, será discutido o quanto os eleitos de fato se preocupam com a referida responsabilidade perante seus eleitores.

${ }^{112}$ G. SARTORI, A teoria da representação no estado representativo moderno, cit., p. 57.
} 
é um órgão cujas faculdades e competências decorrem diretamente da Constituição e o elemento popular aparece tão somente quanto à sua formação e não com referência a sua responsabilidade. A única conclusão plausível a essa teoria passa a ser a de que os órgãos do Estado representam somente a esse, excluindo-se não só o elemento popular, como outro atributo essencial da representação na teoria Sartoriana: a responsabilidade do governo perante os governados.

Como visto, na passagem do mandato imperativo privatístico do Parlamento e na sua internalização como órgão do Estado, o Parlamento assumiu a função de governar os representados, além de tão somente representá-los. Essa segunda função é a "raiz de todos os problemas", do Parlamento de nosso tempo, para G. SARTORI, uma vez que "os Parlamentos operam em condições de equilíbrio delicadíssimo". "Se assumem o ponto de vista dos governados, correm o risco de atrofiar e paralisar o governo; e se, pelo contrário, procuram absorvê-los demais no Estado" (ponto de vista do governante), "corre o risco de não preencher mais sua função representativa" ${ }^{113}$. Ademais, a teoria do órgão não explica onde encontrar o primeiro órgão criador, prejudicando a legitimidade e não superando os obstáculos apresentados pela teoria da representação.

Se a falha consiste na omissão do elemento popular, bastaria então adicioná-lo às bases da teoria da nação ou da teoria do órgão. Mas a operação não se demonstra tão simples. Tomando-se a fórmula da democracia representativa, é de observar as diferenças entre a soberania nacional e a soberania popular. Pela teoria da soberania popular, o eleitorado, composto pelo povo, transmite o poder que este possui aos representantes. É o cidadão-eleitor quem determina a vontade do Estado e não a assembleia eletiva que formula a vontade de governo. Há, assim, o elemento real (o povo em procedimento de escolha) que precede a ficção. Inversamente, a teoria da soberania nacional prevê a criação da vontade nacional a partir da vontade de seus representantes, não havendo vontade pré-existente, mesmo porque a nação é um ente despersonificado, incapaz de se expressar senão por meio de seus porta-vozes. "O representante quer pela nação", nas palavras de CARRÉ DE MALBERG, traduz o mote que constitui o elemento nuclear da representação sob a luz da teoria da nação, cujo conceito revela a noção de um poder concedido "ao representante de querer e de decidir pela nação", como pontua G. SARTORI ${ }^{114}$, que considera que, por misturar os conceitos de "povo" e "nação", Sieyès

${ }^{113}$ G. SARTORI, A teoria da representação no estado representativo moderno, cit., p. 28.

114 G. SARTORI, A teoria da representação no estado representativo moderno, cit., p. 22. CARRÉ DE MALBERG, Contribution à la Theorie Generale de l'État, vol. II, Sireu, Paris, 1922, p. 263-267. 
afirmava que o povo era incapaz de falar e agir por si só, necessitando de seus representantes para fazê-lo. Na verdade, alerta G. SARTORI, os proclamadores da teoria da soberania nacional tinham pela teoria da soberania popular total repugnância, considerando-a como um impedimento à democracia ${ }^{115}$. M.G. FERREIRA FILHO acompanha o raciocínio, assinalando que a teoria da nação tinha por fundo o "temor da burguesia" 116 , que consistia na aversão à possibilidade da plebe participar da formação do governo. Por assim considerar, foi conveniente para tal teoria estabelecer que a nação detivesse o poder e passasse a ser o ente a se representar. O povo, nesse quadro, fora reduzido a mero órgão da nação com a mera função de escolha dos representantes.

De fato, a democracia representativa, no entender de G. SARTORI, deve combinar os elementos da soberania popular com os componentes da soberania da nação. A primeira produz um corpo representativo e não um governo representativo. A segunda gera um governo, mas não necessariamente uma resposta responsável aos governados. "Longe de se excluírem, o povo e a nação se integram e se equilibram um com a outra". Essa é a conclusão de G. SARTORI, na qual a combinação do poder emanado pelo povo com a soberania da nação é que concebe a democracia representativa. E essa combinação se viabiliza por meio dos mecanismos eleitorais, que são "a ponte que une e converte o povo na nação". Apesar de o próprio G. SARTORI considerar que a questão da representação resta ainda aberta e inexplicada, muito contribuiu para acrescentar elementos explicativos à teoria da representação permitindo se vislumbrar o modo do exercício do poder. De um lado, tem-se as eleições como o ponto de partida para criação de um governo. Governo este que traduz a forma de exercício do poder sobre o povo. A soberania popular é, nos termos do autor, uma "ficção deontológica" com base na titularidade do poder. De outro lado, está a soberania da nação, que permite o exercício do poder em nome do povo. Em conjunto, realizam um governo representativo, fundado no consentimento dos governados ${ }^{117}$. A fórmula permite a composição de elementos aparentemente incongruentes: "os cidadãos se tornam um Poder no Estado, mesmo assim o Estado se mantém como Poder sobre os cidadãos" ${ }^{118}$. E com isso se explica a titularidade do poder e o modo de seu exercício. Sua

\footnotetext{
${ }^{115}$ G. SARTORI alerta para a visão reducionista que considera que a teoria da nação visava apenas impedir a democracia. "Não é apenas isso". O autor propõe uma inserção do princípio da soberania popular na soberania da nação para ajustar a teoria à realidade: uma inserção da realidade na ficção. É o que será exposto nos parágrafos seguintes desse estudo. G. SARTORI, A teoria da representação no estado representativo moderno, cit., p. 23 e 29.

${ }^{116}$ M. G. FerReIRA FILHO, Curso de Direito Constitucional, cit., p. 86-87.

${ }_{117}$ G. SARTORI, A teoria da representação no estado representativo moderno, cit., p. 68-69.

${ }^{118}$ G. SARTORI, A teoria da representação no estado representativo moderno, cit., p. 85.
} 
conclusão é que nada melhor explica a natureza da representação senão a teoria da ficção. Outras teorias não saem das armadilhas apresentadas e não resolvem o dilema.

Por todo o exposto, parece residir razão a G. SARTORI ao considerar a ficção como a solução jurídica para o problema da representação política. A fictio juris, ínsita à teoria da nação, permitiu interromper o absolutismo, bem como quebrar o vínculo gerado pelo mandato imperativo, sendo ainda o anteparo legitimador que permite aos regimes representativos funcionar ${ }^{119}$. Não há melhor teoria do que a da representação para explicar o imperativo e a pressão simbólica que se exerce sobre os legitimados a governar.

Repassadas as principais teorias que buscam explicar o fenômeno da representação política, compreende-se que a democracia representativa se construiu com base na liberdade e igualdade - que são valores liberais e ao mesmo tempo princípios democráticos - ao adaptar-se à realidade de uma sociedade que apresentava significante crescimento demográfico e exigiu a ampliação do sufrágio para um maior número de grupos sociais. Como lembra OrIDEs MEZZAROBA, citando Claudia Sousa LeITÃo,

“' 'se a expressão democracia conduz a uma concepção de sociedade, na qual as
liberdades se encontram delimitadas pelo Direito', pode-se dizer que o tema da
representação político-partidária 'retoma esta questão na medida em que busca fórmulas
satisfatórias de organização do poder." 120
Estando claramente delineada a íntima conexão entre os princípios democráticos do Estado de Direito e a representação política, resta agora situar como se apresentam esses elementos na realidade política da democracia hodierna, adicionando-se o componente dos partidos políticos, figura central dos regimes ocidentais da atualidade.

\subsection{O Estado de Partidos}

De acordo com H. KELSEN, um dos elementos mais importantes da democracia são os partidos políticos, que realizam a formação da vontade geral, ao agrupar homens de mesma opinião. "A moderna democracia funda-se inteiramente nos partidos políticos, cuja importância será tanto maior quanto maior for a aplicação encontrada pelo princípio democrático". Assim demonstrou H. KelSEN a significância da democracia pelos partidos, regime político do Parteienstaat, ou Estado de Partidos. O Estado é deste modo caracterizado, pois os partidos

${ }^{119}$ G. SARTORI, A teoria da representação no estado representativo moderno, cit., p. 70-86.

${ }^{120}$ C.S. LEITÃO, A crise dos partidos políticos brasileiros: os dilemas da representação política no Estado intervencionista, Fortaleza, Tipogresso, 1989, p. 34, APUD O. MEZZAROBA, Pressupostos epistemológicos para a democracia eletrônica, in Revista Democracia Digital e Governo Eletrônico, N.1, abr/09, UFSC. 
exercem o papel de órgãos de formação de sua vontade. Para H. KELSEN, o Partido dá a vida política ao indivíduo, que isoladamente não tem existência política, uma vez que não exerce "influência real sobre a formação da vontade do Estado". Por essas considerações é que H. KELSEN categoricamente conclui que "a democracia só poderá existir se os indivíduos se agruparem segundo suas afinidades políticas com o fim de dirigir a vontade geral para os seus fins políticos (...)" e desde que existam formações coletivas como os partidos políticos que possam sintetizar "as vontades iguais de cada um dos indivíduos." 121

Descrevendo o mesmo fenômeno, M.G. FerREIRA FILHO confirma que a democracia atualmente vivenciada "repousa inteiramente sobre os partidos", a quem foi conferida a "tarefa essencial de realizar a autodeterminação social", obtendo-se a vontade geral a partir da "multidão de vontades particulares", despertando e formando a opinião pública, traduzindo a matéria das decisões políticas, "de maneira assimilável para o grande número" e, por fim, sugerindo a solução para os diversos problemas que assolam a sociedade ${ }^{122}$. A coexistência dos partidos com o regime democrático aparece também em PINTO FERREIRA, ao afirmar que "O Estado democrático é um Estado de partidos, refletindo as variadas tendências da opinião pública, que também se espelham nos Parlamentos e congressos." 123

O partido político assume tal relevância, que H. KELSEN inadmite a democracia sem essa figura. A sociedade apresenta interesses diversos e divergentes e, em uma democracia, não se deve exprimir exclusivamente o interesse de um único grupo, mas antes a conciliação entre interesses opostos. Logo, "a formação do povo em partidos políticos na realidade é uma organização necessária a fim de que esses acordos possam ser realizados, a fim de que a vontade geral possa mover-se ao longo de uma linha média." 124

Das ideias deste defensor da democracia pelos partidos extrai-se a imprescindibilidade do estudo do instituto do partido político para a compreensão da democracia ocidental hodierna. $\mathrm{O}$ entendimento de como as decisões dos Tribunais sobre matéria eleitoral afeta a democracia requer a plena apreensão do significado e da dimensão da figura do partido político. Mormente pela crescente valorização que foi e continua sendo atribuída às agremiações políticas, fato revelado com constância nas manifestações das Cortes pátrias. Como será oportunamente identificado, a interpretação jurídica sobre matéria eleitoral que se reflete na recente jurisprudência pende para alçar o partido político a patamares cada vez mais altos, dotando-lhes de tamanho poder, que se torna inimaginável, no presente, outra forma de democracia que não aquela pelos partidos. Sob tal premissa, um olhar mais atento sobre a figura central da democracia hodierna

${ }^{121}$ H. KelSEN, A democracia, cit., p. 38-39.

122 M. G. FERreIRA Filho, Os partidos nas constituições democráticas, Revista Brasileira de Estudos Políticos, São Paulo, 1966, p. 56.

${ }^{123}$ P. FerreIRA, Comentários à Constituição brasileira, 1º. vol., São Paulo, Saraiva, 1989, p. 319.

${ }^{124}$ H. KELSEN, A democracia, cit., p. 38-39. 
auxiliará a desvendar, nos capítulos seguintes, questões atinentes aos julgados submetidos ao exame.

\subsubsection{Conceito de partido político}

Iniciando-se pela decomposição do termo, em AuRÉLIO BUARQUE DE HOLANDA FERREIRA encontram-se os seguintes significados para a palavra "partido", que guardam alguma relação com o tema em análise: "1) organização cujos membros programam e realizam uma ação comum com fins políticos e sociais. Facção; 2) associação de pessoas unidades pelos mesmos interesses ideais e iguais objetivos; liga."125

José BISPO SOBRINHO, traçando seus comentários à Lei Orgânica dos Partidos Políticos, define-os como: “A organização de parte ou parcela do povo, segundo os mesmos ideais políticos, com objetivo de desenvolver uma ação comum voltada ao exercício dos negócios do Governo”. ${ }^{126}$ Sua definição contém a finalidade do objeto definindo, pois os partidos políticos têm como propósito a tomada do poder por meios democráticos, isto é, pelo voto, segundo o autor. Adiciona ao seu conceito que o partido político é uma abstração jurídica que depende das pessoas físicas que o integram para consecução de seus ideais programáticos, o que requer a existência de um programa, elaborado a partir de ideais comuns dessas pessoas que compõem a associação partidária. O próprio termo "partidária" deixa também a noção de tomar-se partido de certa opinião, de certo valor, ou de certo ideal. Um grupo de pessoas que compartilham desses ideais se associam formando uma agremiação em defesa de objetivos comuns. Essa definição simples de associação se transforma em uma espécie - a associação política - exatamente a partir de seus fins, políticos. A definição encontrada em P. FERREIRA retrata justamente esse quadro. Para o autor, partidos políticos são grupos sociais de pessoas, "que, tendo a mesma concepção sobre a forma desejável de sociedade do Estado, se congregam para a conquista do poder político, para efeito de realizar um determinado programa". Trata-se de "verdadeiros instrumentos de governo constitucional e coexistem hoje com o regime democrático" 127.

125 A. B. Holanda Ferreira, Novo Dicionário da Língua Portuguesa, 2a . ed., Rio de Janeiro, Nova Fronteira, 1986, p. 1274.

${ }^{126}$ J. BISPO SOBRINHO, Comentários à lei orgânica dos partidos políticos (Lei N. 9096, de 19 de setembro de 1995), Brasília Jurídica, 1996, p. 17.

${ }^{127}$ P. FERREIRA, Manual prático de direito eleitoral, São Paulo, Saraiva, 1973, p.15. V. também P. FERREIRA, Comentários à Constituição brasileira, cit., p. 319. 
J. AFONSO DA SiLva apresenta definição na qual partido é considerado como um grupo de pessoas formado em torno de um conteúdo ideológico, que busca a defesa de interesses para a conquista legal do poder ${ }^{128}$. Mas, como assevera J. BISPO SOBRINHO, o conceito de partido político não deve se restringir à ideia de reunião de parte do povo e à igualdade de opiniões ${ }^{129}$. A noção de partido político apresentada por $\mathrm{J}$. AFONSO DA SILVA pode, à primeira vista, soar sujeita a tal crítica:

\footnotetext{
"O partido político é uma forma de agremiação de um grupo social que se propõe a organizar, coordenar e instrumentar a vontade popular com o fim de assumir o poder para realizar seu programa de governo." 130
}

Mas a um olhar mais atento, percebe-se que a definição de J. AFONSO DA SILVA traz em seu bojo outro aspecto fundamental que compõe o conceito: o da instrumentalização da vontade popular.

Assim considerando e retomando-se os ensinamentos de J. BISPO SOBRINHO, ${ }^{131}$ agrega-se ao conceito de partido político a noção de que se trata, na verdade, de um instrumento do sistema representativo, pelo qual o cidadão exerce sua soberania, votando e sendo votado, considerando-se o regime democrático, que é o pano de fundo de toda questão. O. MEZZAROBA resume em poucas palavras a correlação existente na democracia hodierna entre o Estado, a representação política e os partidos, asseverando que "viver democraticamente significa captar esta vontade coletiva, a partir dos mecanismos representativos, e, neste caso, uma das peças basilares do Estado democrático é o partido político." ${ }^{132}$ Por isso e por todas as questões suscitadas na introdução, valioso todo estudo das relações existentes entre o regime democrático e os partidos políticos, que, conjuntamente com as teorias da representação política, permitirão uma melhor compreensão das questões abordadas neste trabalho.

\footnotetext{
128 J. AfONSO DA SILVA, Curso de Direito Constitucional Positivo, cit., p. 394.

${ }^{129}$ J. BISPO SoBrinHo, Comentários à lei orgânica dos partidos políticos (Lei N. 9096, de 19 de setembro de 1995), cit., p. 18.

${ }^{130}$ J. AfONSO DA SILVA, Curso de Direito Constitucional Positivo, cit., p. 394.

${ }^{131}$ J. BISPO SOBRINHO, Comentários à lei orgânica dos partidos políticos (Lei N. 9096, de 19 de setembro de 1995), cit., p. 18.

${ }^{132}$ O. MeZzaroba, A democracia, os partidos políticos e o Estado, in Revista Sequência n ${ }^{\circ} 43$, Curso de Pós Graduação em Direito - UFSC, dez/2001, p. 29-44.
} 


\subsubsection{Origem do partido político}

O partido político tem suas origens ligadas ao sistema representativo e à democracia moderna e se apresentou como o instrumento necessário para a coordenação das eleições e para satisfazer um processo competitivo decorrente dessas.

Apesar de encontrarmos em obras traduzidas a expressão "partidos" como, por exemplo, na Constituição de Atenas, de Aristóteles, verifica-se que a conversão para outro idioma pode levar a ideias errôneas. De fato, na Grécia Antiga os Poderes do Estado não estavam organizados em partidos. Inclusive, por não haver eleições pelo voto, inexistia a função de agregação das opiniões e a competição por cargos eletivos. O mesmo se passou em Roma. Ao invés de partidos, tratava-se, assim como na Grécia, de classes sociais.

Na prevalência do pensamento liberal da era moderna, observou-se uma hostilização aos partidos. Pensadores liberais repugnavam o partido em troca da suficiência da razão. Na entrada do século XIX, a legislação desconhecia essa figura. Silenciava-se a respeito do instituto. O Estado parlamentar representativo do século XIX era contra o reconhecimento e a legalização dos partidos. Isso explica a ausência desses nos textos constitucionais, nas leis e doutrinas do direito público da época. A origem do partido, tal como é conhecida hodiernamente, data, de acordo com MAURICE DUVERGER, ${ }^{133}$ da segunda metade do século XIX. A assertiva poderia parecer cronologicamente incorreta. J. AFONSO DA SILVA lembra que anteriormente a essa data, as associações eram apenas facções favoráveis ou contrárias à determinada força política. ${ }^{134} \mathrm{O}$ surgimento efetivo dos partidos veio com a estabilidade e a organização crescente desses grupos, que passaram a indicar pessoas para representar as ideias comuns do grupo. E, também, pelo fato de não serem apenas grupos de pressão para influência das decisões governamentais, mas acima disso, grupos que disputariam o acesso ao poder político. No início do século XX, $\mathrm{H}$. KELSEN já dizia ser a democracia moderna fundada nos partidos, cuja importância estava

\footnotetext{
${ }^{133}$ M. DuVERger, Les partis politiques, 3a.ed., Paris, A. Colin, 1958, p. 1-13. Edição brasileira: Os partidos políticos, trad. Cristiano Monteiro Oiticica, Rio de Janeiro, Zahar, 1970, p. 19-33.

${ }^{134}$ Tal como os agrupamentos rivais na Itália do século XII ao XV, os Guelfos, partidários do Papa e seus opositores os Gibelinos, ou o Clube Bretão da época da Revolução Francesa, que se transformou em Jacobinos, opositores dos Girondinos ou à mesma época as correntes Whig e Tory, que evoluíram posteriormente nos Partidos Liberais e Conservador na Inglaterra. Vide, J. AFOnSO DA SILVA, Curso de Direito Constitucional Positivo, cit., p. 395 e M. G. FERREIRA FILHO, A democracia no limiar do século XXI, cit., p. 176.
} 
ligada diretamente a realização do princípio democrático ${ }^{135}$. A partir da Segunda Grande Guerra, em todas as democracias ocidentais, o parlamentarismo representativo entrou em crise, por não corresponder mais à realidade política, marcada pela emancipação das classes sociais inferiores e a consequente premência de organização das massas.

\subsubsection{Da democracia representativa à democracia pelos partidos}

Segundo G. LEIBHÖLZ, o pensamento liberal encontrou sua expressão na chamada democracia parlamentar representativa. ${ }^{136}$ Lembra o autor que as constituições liberais não consideravam os partidos, pois a legalização destes punha em xeque o sistema representativo parlamentar da época. ${ }^{137}$ Adverte ainda que o pensamento liberaldemocrático era mais liberal do que propriamente democrático, pois democracia e liberalismo são fundados em princípios diferentes - dentre os quais a extensão do direito de voto é o principal. Somente com a introdução das massas no processo eleitoral é que se forma a democracia ocidental, tal como é conhecida hodiernamente. Por meio desse processo concretizou-se a figura do partido político como o instrumento necessário para coordenação dessas massas na escolha dos representantes. Surge então para G. LEIBHÖLZ o Estado de Partidos ou Democracia de Partidos. Sua principal diferença para a democracia parlamentar representativa é que o princípio que porta a formação da vontade geral do povo não é o mesmo da representação, mas os da democracia participativa ou plebiscitária, na qual a vontade da maioria dos cidadãos se identifica com a vontade geral.

Como consequência desse quadro, o Parlamento perde seu caráter inicial - pois não corresponde mais às exigências dos tempos - e se transforma em instituição do Estado de Partidos, pois sua composição deriva de membros filiados a uma agremiação partidária. E consequentemente, muda a postura de cada parlamentar, que se torna um indivíduo subordinado à vontade geral e não mais um representante, que é eleito, em teoria, não por suas qualidades, tal como na democracia representativa, mas pela qualidade do partido. Com isso, diz o autor, há uma tensão na posição dúplice do deputado, que de

\footnotetext{
${ }^{135} \mathrm{Na}$ década de 1920, H. KELSEN realizou alguns ensaios sobre a democracia. Mas seria nos anos trinta e no pós-guerra que passou a defendê-la.

${ }^{136}$ G. LEIBHÖLZ, La Rappresentazione nella Democrazia, cit., p. 303-405.

137 Para H. KELSEN, o descrédito dos partidos era defendido pela doutrina política da monarquia constitucional como forma de atacar a democracia. Tal doutrina pregava um incompativilidade entre os partidos e o Estado. Profere o autor que "só a ilusão ou a hipocrisia pode acreditar que a democracia seja possível sem partidos políticos”. H. KELSEN, A democracia, cit., p. 40.
} 
um lado, é portador da representação popular e, de outro, expoente de uma organização concreta, o partido $^{138}$.

Nessa passagem da democracia representativa para o Estado de Partidos, a partir da inclusão das massas no processo deliberativo (processo de progressiva democratização) e do crescimento dos partidos que giravam em torno de interesses regionais, observou-se o fortalecimento dessa instituição justamente pela positivação nos ordenamentos jurídicos. Mas isso tardou a ocorrer. Como retrata G. LEIBHÖLZ, se a realidade da segunda metade da década de 1920 já espelhava um Estado de Partidos, a doutrina e a legislação ainda viam os partidos como fenômenos extra constitucionais. Apenas na metade do século XX é que se verifica a mencionada constitucionalização dos partidos, como, por exemplo, na Constituição alemã, a Lei Fundamental de Bonn, que definiu os partidos como parte construtiva da estrutura constitucional. De acordo com $\mathrm{H}$. KELSEN, a constitucionalização dos partidos se reveste de fundamental relevância, pois ao consagrar "a existência dos partidos políticos, torna-se também possível democratizar, nesta esfera, a formação da vontade geral." 139

Importante para o presente estudo a digressão crítica feita por G. LEIBHÖLZ à Constituição alemã, que tentou conciliar o inconciliável, ou seja, o sistema representativo parlamentar com a realidade do Estado de Partidos, ao abrigar a tese de que um partido (e não um deputado) representa o povo como totalidade. Prevê também a Carta Magna germânica que o deputado se legitima da representação da totalidade do povo, quando se liga a um partido. De outra face, pelo artigo 38 da própria Lei Fundamental de Bonn, o deputado deve tomar sua decisão em liberdade de consciência, não se vinculando a nada. Porém, se a decisão parlamentar depende da fidelidade ao partido, não há como ser livre, comenta o G. LEIBHÖLz. Para o autor, é um equívoco unir duas formas democráticas distintas, como a democracia moderna do Estado dos Partidos e a democracia parlamentar representativa. Apesar da Lei de Bonn adotar dois princípios estruturais da democracia logicamente diversos ${ }^{140}$, segundo G. LEIBHÖLZ, a Constituição alemã reconheceu que a democracia do Estado de Partidos tornara-se uma realidade política ${ }^{141}$ e é considerada como um marco da constitucionalização das agremiações partidárias.

\footnotetext{
${ }^{138}$ G. LEIBHÖLZ, La Rappresentazione nella Democrazia, cit., p. 303-405. Essa importante constatação será de suma importância para os debates a respeito da fidelidade partidária.

${ }^{139}$ H. KelSEN, A democracia, cit., p. 42.

140 G. LEIBHÖLZ diz que a tarefa do intérprete nesse caso, passa a ser de conciliar em concreto os dois princípios divergentes, uma vez que se evidenciou a dúplice posição do deputado. G. LEIBHÖLZ, La Rappresentazione nella Democrazia, cit., p. 303-405.

${ }^{141}$ Isso não significa que G. LEIBHÖLZ não se inquiete com perda da liberdade originária do deputado, que é
} 
Como relembra M.G. Ferreira FilHO, a atual Constituição brasileira repetiu a orientação de sua antecessora, ambas com inspiração na Lei Fundamental alemã de 1949, ao determinar os princípios estruturantes dos estatutos dos partidos políticos, de forma que essas organizações pudessem colaborar "com o funcionamento das instituições democráticas, realizando a formação política do povo, divulgando planos e alternativas de governo, selecionando candidatos". De outro lado, alerta o mestre, o constituinte preocupou-se em limitar o poder dos partidos, impedindo que se tornem perturbadores das referidas instituições, evitando o risco de predomínio de oligarquias e da concentração do poder econômico. O excesso de poder dos partidos é um dos venenos que são capazes de destruir ou deformar a democracia, conforme assevera M.G. FERREIRA FILHO ${ }^{142}$. O fortalecimento dos partidos políticos pode tanto incrementar o caráter democrático do regime político - afinal nada os substitui em sua função no Estado de Partidos - como, ao contrário, transformá-lo numa "oligarquia pelos partidos". O. MEZZARoBA, em leitura de JOHANN CASPAR BLUNTSCHLI, busca demonstrar que

"quando o partido busca subordinar os interesses do Estado aos seus interesses particulares, deixa de atuar como partido para assumir a função de facção. Via de regra, a facção não tem por objetivo servir ao Estado, mas, simplesmente, fazer com que o Estado a sirva. Isto é, a facção não tem como finalidade servir aos interesses comuns, somente aos seus próprios interesses egoísticos." 143

Guardem-se essas advertências para a conclusão de como as decisões judiciais afetam o Estado Democrático de Direito.

\footnotetext{
“sufocado pelos partidos”. G. LEIBHÖLZ é um crítico do vínculo partidário, das sociedades parciais. Para o autor, "futura lei sobre partidos não pode sancionar a obrigação de o deputado pertencer a um grupo parlamentar. A expulsão ou troca de partido não deve implicar perda do mandato." Tradução livre. G. LEIBHÖLZ, La Rappresentazione nella Democrazia, cit., p. 303-405.

${ }^{142}$ M. G. FerreIRA FilHo, Comentários à Constituição brasileira de 1988, $3^{\text {a }}$.ed., Saraiva, São Paulo, 2000, p. 133.

143 J.C. Bluntschli, El Progreso en la Evolución de los Partidos, in Kurt LenK, Franz Neumann, Teoría y Sociología Críticas de los Partidos Políticos, trad. Ignácio de Otto, Barcelona, Anagrama, 1980, p. 128129, APUD O. MEZZAROBA, A democracia, os partidos políticos e o Estado, cit., p. 29-44.
} 


\section{A RECENTE JURISPRUDÊNCIA ELEITORIAL E A ATUAÇÃO POLÊMICA DAS CORTES}

\subsection{Considerações iniciais}

A proposta de exame da recente jurisprudência formada em matéria eleitoral visa fornecer elementos para a percepção da evolução das instituições democráticas pátrias, por meio da observação, principalmente, da super atividade das Cortes Nacionais, da inflexão do posicionamento dessas perante determinadas questões de alta indagação, bem como do uso alargado da hermenêutica constitucional. É nesse sentido que, no presente capítulo, será estudada a atuação da Justiça Eleitoral e da Corte Suprema, a partir de casos concretos atinentes a temas eleitorais, que envolveram a sociedade em profundos debates.

Desse modo, em tópico inicial, tratar-se-á da anacrônica introdução do fenômeno da verticalização que restringiu a autonomia dos partidos políticos ao limitar sua liberdade de estabelecer coligações, veiculada por meio da Instrução n. 55 contida na Resolução N. 20.993/02, que interpretou o dispositivo contido no art. 6º da Lei das Eleições $^{144}$. As regras inovadoras no campo eleitoral se perfizeram via regulamento, ato normativo secundário, atentando ao princípio basilar do Estado Democrático de Direito: a estrita legalidade ${ }^{145}$. Provocado reiteradamente para rever sua posição, o TSE volta a se manifestar em novo ano de eleições gerais - 2006 - reafirmando o instituto da verticalização das coligações, que seria, poucos dias após, revertido pela atuação do Congresso Nacional. Com a aprovação da Emenda Constitucional N. 52/06, pretendendo liberar das amarras incidentes sobre as negociações políticas, retomou-se a autonomia partidária, fortalecendo o poder dos partidos e prestigiando a liberdade de associação, em detrimento da verticalização imposta pelo TSE desde $2002^{146}$. Este será o primeiro dos exemplos estudados no qual o Congresso Nacional usou de suas prerrogativas para alterar

\footnotetext{
144 TSE, Res. N. 20.993, rel. Min. Fernando Neves, 26.02.02, DJ 12.03.02.

145 M. HERMAN SALEM CAGGIANO, Legislação eleitoral e hermenêutica política x segurança jurídica, Cláudio Lembo (coord.), Barueri, Manole/CEPES, 2006.

${ }^{146}$ M. HeRman SAlEm CAgGiano, A fenomenologia dos trânsfugas no cenário político eleitoral brasileiro, in Claudio Lembo (Coord.), M. Herman Salem Caggiano (Org.), O Voto nas Américas, CEPES, 2008, p.224.
} 
o direcionamento dado pelo Judiciário, que por sua vez, não deixou para o Legislativo a última palavra. A alteração promovida às pressas pelo constituinte derivado deveria respeitar a carência anual constitucionalmente fixada, segundo o Judiciário. De modo que, as próximas eleições gerais livres da obrigação da verticalização judicialmente imposta aos partidos, ocorrerão em outubro de 2010.

A ingerência das Cortes em temas políticos e o desfazimento pelo Legislativo da construção elaborada a partir das decisões dos Tribunais voltaram a se repetir em nova oportunidade. Tal fato foi observado quando da definição do número máximo de Vereadores por Município a partir de julgado do STF, que em sede de controle incidental de constitucionalidade, veio a estipular novas regras de conduta aos Municípios para editar suas Leis Orgânicas no que tange ao número de cadeiras das respectivas Câmaras. Essa decisão foi posteriormente regulamentada em 2004 pela Corte Eleitoral que, em pleno ano de certame eleitoral, definiu regras limitadoras sobre o número de Vereadores a serem eleitos a partir de critérios que consideram o tamanho da população de cada Município.

Embora pudesse soar que o assunto estaria sacramentado a partir da definição dada pelos Tribunais, eis que, às vésperas do final do ano de 2008, a sociedade civil se indignou novamente com a notícia da aprovação de Emenda ao texto constitucional visando aumentar o número de vagas parlamentares para os Vereadores, de forma a praticamente restituir a maior parte das 8.481 cadeiras municipais eliminadas pela Corte Eleitoral em abril de $2004^{147}$.

Quando aprovada no Senado, em 18 de dezembro de 2008, a proposta de Emenda à Constituição causara nova "crise institucional" entre as Casas do Congresso Nacional. O Presidente da Câmara dos Deputados, Arlindo Chinaglia, teria se recusado a assinar a promulgação da citada Emenda, exercendo poder de veto não previsto no ordenamento, na opinião do Senador Garibaldi Alves, Presidente do Senado, que acabaria por levar o caso à apreciação do Supremo ${ }^{148}$.

A intercorrência entre as casas do Congresso demonstra que os temas em pauta não se encontram finados e, ao contrário do que inicialmente se poderia imaginar, reaparecem com enorme dinamismo. Em outras palavras, a limitação determinada pelo

${ }^{147}$ O Estado de São Paulo, Senado aprova aumento de Vereadores para 59.791 no País, São Paulo, 18.12.08, disponível (on line) in http://www.estadao.com.br/noticias/, [19.12.08].

${ }^{148}$ A crise foi estampada nos principais periódicos nacionais. V., O Estado de São Paulo, Agência Estado, Emenda dos Vereadores provoca crise no Congresso, São Paulo, 19.12.08, p. A10. 
TSE há cinco anos sofreu nova reviravolta e deixou transparecer não somente novo embate entre Poderes Legislativo e Judiciário, mas também desentendimento entre as próprias Casas Legislativas. Em setembro de 2009 foi promulgada a EC-58, restituindo-se as vagas cortadas anteriormente pelo Judiciário, que não deixará de se manifestar sobre a referida Emenda, pois tanto a Procuradoria Geral da República quanto a Ordem dos Advogados do Brasil propuseram Ação de Declaração de Inconstitucionalidade no Supremo Tribunal ${ }^{149}$.

No que tange às eleições municipais, encontra-se na recente jurisprudência eleitoral o que se pode chamar de barreira à "carreira política de Prefeito". Por força de interpretação do texto constitucional, a Corte Eleitoral vem se posicionando no sentido de não permitir o registro da candidatura de Prefeito que tenha cumprido dois mandatos consecutivos, ainda que este pleiteie o novo mandato em outro Município diverso daquele que exerce suas funções e mesmo quando desincompatibilizado.

Completa-se o contexto com o exame da cláusula de barreira, estabelecida pela Lei N. 9096/95 em seu artigo 13, cuja aplicação estava inicialmente prevista para o certame de 2006. Porém, o instituto foi extirpado pelo STF no julgamento das ADI N. 1.351 e N. 1.354 em dezembro de 2006, ajuizadas pelos partidos de pouca representatividade parlamentar - os principais afetados pela regra legal e sujeitos ao desaparecimento do cenário parlamentar. De certo, o fracionamento e a proliferação de legendas sem conteúdo ideológico reforçam o sentimento de fragilidade do sistema partidário nacional, que, de outra face, graças ao reposicionamento de nossas Cortes, ganha novas forças, com aumento da autonomia e autodeterminação.

A escolha das decisões específicas acima enumeradas decorre não somente da sua recente existência. Por refletirem o que se denomina de "ativismo judicial" e por trazerem a base para as críticas sobre os procedimentos e formas adotadas pela Corte Eleitoral no uso de suas atribuições normatizadoras, aliadas à "interpretação expansiva" adotada pelo Supremo Tribunal, foram esses casos e fatos considerados como aqueles que melhor fornecem elementos para análise das hipóteses suscitadas no intróito do presente trabalho. Ademais, ressurge recentemente o questionamento acerca dos poderes normativos da Corte Eleitoral e a limitação do escopo de atuação da justiça especializada, bem como o conflito com o Legislativo, mormente quando do cumprimento das decisões da Justiça Eleitoral. Todas essas questões, advindas de reiterados pronunciamentos e constantes formulações normativas, serão objeto de análise desse estudo.

${ }^{149}$ STF, ADI-MC N. 4.307/DF, rel. Min. Cármen Lúcia, 02.10.09, DJ 08.10.09. 


\subsection{A verticalização das coligações partidárias}

A figura da verticalização, que veio a ser introduzida no ordenamento jurídico brasileiro por meio da atividade hermenêutica da Corte Eleitoral, consiste na imposição da coerência - por identidade ou continência - entre as coligações partidárias, cujo paradigma é a aliança formada para disputa do pleito eleitoral em circunscrição nacional. O conceito se aclara nas palavras de José AFONSO DA SILVA, para quem a verticalização, ou a "vinculação vertical obrigatória" - como diz o mestre - significa a “obrigatoriedade de vinculação entre as candidaturas em âmbito nacional, estadual, distrital ou municipal" $" 150$.

\subsubsection{A normatização das coligações partidárias}

Ao comentar-se sobre a introdução de regras a balizar a formação de coligações em eleições majoritárias e proporcionais faz-se remissão à Lei N. 9.504/97. Editada em 30 de setembro de 1997 e conhecida como 'Lei das Eleições', a norma encontra-se em plena vigência. Seu objetivo foi padronizar as condutas eleitorais, evitando que novas exigências fossem formuladas a cada período eleitoral. O dispositivo contido no caput do art. $6^{\circ}$. da norma assinalada estabelecia limites à faculdade dos partidos de se coligarem:

"Lei N. 9.504/97 - Art. 6. É facultado aos partidos políticos, dentro da mesma circunscrição, celebrar coligações para eleição majoritária, proporcional, ou para ambas, podendo, neste último caso, formar-se mais de uma coligação para a eleição proporcional dentre os partidos que integram a coligação para o pleito majoritário."

Embora a Lei N. 9.504/97 viesse a ser aplicada nas eleições gerais de 1998, não incidiria a obrigatoriedade da verticalização das coligações. É bem verdade que existiram precedentes legais a regrar as coligações, bem como jurisprudência formada sobre a questão.

${ }^{150}$ J. AfONSO DA SILva, Curso de direito constitucional positivo, 27ª . ed., São Paulo, Malheiros, 2006, p. 406. 
Ainda sob a égide da Carta Constitucional anterior, a Lei N. 7.493/86 regulamentou a disciplina para as eleições gerais daquele ano, prevendo, quanto à matéria em análise:

“Lei N. 7.493/86 - Art. 6. É facultado aos partidos políticos, celebrar coligações para o registro de candidatos à eleição proporcional, ou a ambas.

$\S 1^{\circ}$. É vedado ao Partido Político celebrar coligações diferentes para a eleição majoritária e para a eleição proporcional."

No mesmo sentido dessa norma, a Lei N. 7.664/88 - editada igualmente na vigência da Carta de 1967, em 29 de junho de 1988 - e a Lei N. 8.214/91 facultaram a formalização de alianças em ambos os tipos de eleições, consideradas separada ou conjuntamente, proibindo, contudo, coligações distintas para a eleição majoritária e a proporcional. Nesse ínterim, a Lei N. 7.773/89 permitiu amplamente a coligação entre agremiações políticas, sem condicioná-las aos limites da circunscrição ${ }^{151}$.

Por sua vez, ao dispor sobre as eleições gerais de 1994, a Lei N. 8.713/93 introduziu nova regra para a formação de alianças, facultando, em seu art. $6^{\circ}$., as coligações para as eleições majoritárias, proporcionais ou ambas, "desde que elas não sejam diferentes dentro da mesma circunscrição”. Tal dispositivo viria a ser retomado pela Lei N. 9.504 em 1997.

A antecessora da norma vigente, a Lei N. 9.100/95, que estabeleceu normas para as eleições de 3 de outubro de 1996, prescreveu vedações às coligações partidárias de forma ligeiramente diversa. Seu artigo $6^{\circ}$. continha a seguinte prescrição:

"Lei N. 9.100/95 - Art. 6. Serão admitidas coligações se celebradas conjuntamente para as eleições majoritárias e proporcional, e integradas pelos mesmos partidos, ou se celebradas apenas para as eleições majoritárias."

A lei vedava, portanto, exclusivamente as coligações para as disputas proporcionais e exigia semelhança na composição dos blocos partidários para as coligações majoritárias e para as coligações feitas em ambos os sistemas eleitorais. Inconformado com a proibição colocada para o pleito eleitoral que se avizinhava, o PC do B - Partido Comunista do Brasil, propôs Medida Cautelar na Ação Direta de Inconstitucionalidade ADI-MC N. $1.407^{152}$ - alegando descumprimento do princípio fundamental da autonomia

${ }^{151} \mathrm{O}$ art. $5^{\circ}$. da Lei N. 7.773 de 08.06.89, dispôs: "Dois ou mais partidos políticos, nas condições do artigo anterior, poderão coligar-se para registro dos candidatos comuns." O preceito transmite a ampla liberdade de coligações, condizente com o espírito democrático da nova Carta Constitucional, à época recém promulgada.

${ }^{152}$ STF, Pleno, ADI-MC N. 1.407/DF, rel. Min. Celso de Mello, 07.03.96, DJ 24.11.00. 
partidária contida no art. $17 \S 1^{\circ}$. CF/88, ao se impor restrição ao exercício da liberdade partidária.

Essa fora a primeira insurgência quanto ao dispositivo que regulava as coligações partidárias $^{153}$, na qual o partido relatou ser difícil para as pequenas legendas conseguirem eleger Deputados com os próprios votos que lhe fossem atribuídos, sendo a coligação no pleito proporcional essencial para a representatividade dos partidos minoritários na Câmara. O Supremo se pronunciaria em 7 de março de 1996 indeferindo liminarmente a Ação Direta, de relatoria do Ministro Celso de Mello. O relator argumentou ser a autonomia dos partidos assunto referente à organização interna desses, não significando esse princípio qualquer restrição ao legislador que estabeleça normas ao funcionamento parlamentar, cuja atuação é garantida pela reserva constitucional de ação disciplinadora estatutária $(\mathrm{CF} / 88$, art. 22, I). Oportuno transcrever alguns trechos da ementa e do voto do Ministro relator, que resumem a importante decisão do Tribunal:

\begin{abstract}
"PROCESSO ELEITORAL E PRINCÍPIO DA RESERVA CONSTITUCIONAL DE COMPETÊNCIA LEGISLATIVA DO CONGRESSO NACIONAL (CF, art. 22, I). - O princípio da autonomia partidária - considerada a estrita delimitação temática de sua abrangência conceitual - não se qualifica como elemento de restrição ao poder normativo do Congresso Nacional, a quem assiste, mediante lei, a competência indisponível para disciplinar o processo eleitoral e, também, para prescrever regras gerais que os atores do processo eleitoral, para efeito de disputa do poder político, deverão observar, em suas relações externas, na celebração das coligações partidárias. SUBMISSÃO NORMATIVA DOS PARTIDOS POLÍTICOS ĂS DIRETRIZES LEGAIS DO PROCESSO ELEITORAL. Os Partidos Políticos estão sujeitos, no que se refere à regência normativa de todas as fases do processo eleitoral, ao ordenamento jurídico positivado pelo Poder Público em sede legislativa. Temas associados à disciplinação das coligações partidárias subsumem-se à noção de processo eleitoral, submetendo-se, em conseqüência, ao princípio da reserva constitucional de competência legislativa do Congresso Nacional. AUTONOMIA PARTIDÁRIA E PROCESSO ELEITORAL. - O princípio da autonomia partidária não é oponível ao Estado, que dispõe de poder constitucional para, em sede legislativa, estabelecer a regulação normativa concernente ao processo eleitoral. O postulado da autonomia partidária não pode ser invocado para excluir os Partidos Políticos - como se estes fossem entidades infensas e imunes à ação legislativa do Estado - da situação de necessária observância das regras legais que disciplinam o processo eleitoral em todas as suas fases. VEDAÇÃO DE COLIGAÇÕES PARTIDÁRIAS APENAS NAS ELEIÇÕES PROPORCIONAIS - PROIBIÇÃO LEGAL QUE NÃO SE REVELA ARBITRÁRIA OU IRRAZOÁVEL - RESPEITO À CLÁUSULA DO SUBSTANTIVE DUE PROCESS OF LAW. (...)

A norma estatal, que não veicula qualquer conteúdo de irrazoabilidade, presta obséquio ao postulado da proporcionalidade, ajustando-se à cláusula que consagra, em sua dimensão material, o princípio do substantive due process of law $\left(\mathrm{CF}\right.$, art. $5^{\circ}$, LIV). Essa cláusula tutelar, ao inibir os efeitos prejudiciais decorrentes do abuso de Poder Legislativo, enfatiza a noção de que a prerrogativa de legislar outorgada ao Estado
\end{abstract}

${ }^{153}$ A ADI-MC N. 1.063 também é apontada como ação de defesa à autonomia partidária. Todavia, em seu mérito, a discussão abrangeu a chamada "candidatura nata". A ação visava à declaração de inconstitucionalidade dos arts. $8^{\circ}, \S 1^{\circ}$. e $9^{\circ}$. da Lei N. 8.713/93, que não tratava sobre coligações. STF, Pleno, ADI-MC N. 1.063, rel. Min. Celso de Mello, 18.05.94, DJ 27.04.01. 
constitui atribuição jurídica essencialmente limitada, ainda que o momento de abstrata instauração normativa possa repousar em juízo meramente político ou discricionário do legislador." ${ }^{154}$ (grifos nossos)

Como se observa, a corrente prevalecente no Supremo àquela época valorizava a autonomia partidária, contendo-a, contudo, dentro dos limites internos e estatutários dos partidos, não permitindo que suas faculdades de agir extrapolassem os limites da lei, de modo a atingir a discricionariedade do legislador.

\subsubsection{Resoluções N. 20.121 e N. 20.126 do TSE - A interpretação inicial sobre o instituto das coligações}

Em que pese a contínua edição legislativa a normatizar as eleições, como praxe a se observar às vésperas dos pleitos eleitorais, o TSE viria a ser acionado inúmeras vezes pelo instrumento da Consulta, ora para dirimir dúvidas acerca do processo eleitoral, ora na tentativa de obter-se resultado favorável ao partido representado pelo Deputado consulente.

Debaixo da normatização criada pela Lei N. 9.504/97, relativamente ao instituto das coligações partidárias, as primeiras provocações à Corte Eleitoral de que se tem notícia se processariam através das Consultas N. $358^{155}$ e $382^{156}$ de 1998. A dúvida dos partidos girava em torno da dificuldade de interpretação do dispositivo legal e das múltiplas configurações alternativas: combinações passíveis de se montarem entre eleições

\footnotetext{
${ }^{154}$ STF, Pleno, ADI-MC N. 1.407/DF, rel. Min. Celso de Mello, 07.03.96, DJ 24.11.00.

${ }^{155} \mathrm{Na}$ Consulta N. 358/DF, o Deputado Valdemar Costa Neto formulara a seguinte indagação: "Na hipótese de os partidos A, B, C e D, dentro da mesma circunscrição, coligarem-se nas eleições de Governador e Senador, podem tais agremiações: a) coligar-se para Deputado Federal; e, na eleição de Deputado Estadual, coligar-se somente os partidos A, B e C, e o partido D concorrer, no mesmo pleito, isoladamente? b) Coligarse, hipoteticamente, A e B para Deputado Federal, formando um subconjunto; coligar-se, para a mesma eleição, os partidos C e D, formando outro subconjunto; e, na eleição de Deputado Estadual, cada um destes partidos concorrer isoladamente?" Como se pode observar a partir das conclusões aqui retratadas, a resposta do TSE a tais questionamentos foi positiva. TSE, Consulta N. 358 e Res. N. 20.121, rel. Min. Néri da Silveira, 12.03.98, DJ 16.04.98.

${ }^{156}$ Na Consulta N. 382/DF, elaborada pelo Deputado Pedro Henry (PMDB-MT), perguntou-se, de forma resumida: “1) Qual das eleições, majoritária ou proporcional, é possível a coligação: Governador - Deputado Federal, ou Governador - Deputado Estadual?; 2) É possível coligações diferentes para Governador Senador?; 3) A eleição majoritária está vinculada a eleição proporcional e a qual eleição proporcional está vinculada a eleição majoritária? (...); 4) Considerando-se que a coligação da eleição proporcional para Deputado Federal seja a mesma da eleição majoritária para Governador, formadas pelos partidos $\mathrm{A}+\mathrm{B}+\mathrm{C}+\mathrm{D}+\mathrm{E}+\mathrm{F}$, poderão ser formadas coligações diferentes para a eleição de Deputados Estaduais? (...).TSE, Consulta N. 382 e Res. 20.126, rel. Min. Néri da Silveira, 12.03.98, DJ 16.04.98.
} 
majoritárias, proporcionais ou ambas, com eleições para Governador, Senador, Deputados Federais, Estaduais e a variável quantidade de partidos.

Em resposta às duas Consultas, o TSE editou as Resoluções N. 20.121/98 e N. 20.126/98 ${ }^{157}$, nas quais firmou posicionamento acerca do dispositivo legal (art. $6^{\circ}$. da Lei N. 9.504/97) no seguinte sentido:

a) A lei criou a faculdade às agremiações políticas para que ajustassem coligações, seja em eleições para cargos de votação majoritária, seja quando de votação proporcional ou, inclusive, em ambas. É o que se extrai da simples leitura da primeira parte do referido artigo;

b) Apenas nos casos em que se firmassem acordos de coligação para ambas as eleições - majoritárias e proporcionais - seria admitida a hipótese de formação de arranjos diversos para o pleito proporcional, desde que realizados dentre os partidos que compõem a coligação para o certame majoritário;

c) Decorrem do dispositivo legal de que acima se fez menção:

1. A permissão para, na eleição proporcional, existir uma ou mais coligações para a eleição de Deputado Federal ou Estadual.

2. A inadmissibilidade de incluir na coligação proporcional, partido que não compõe a coligação majoritária, formando aliança diversa com partido que integra o bloco composto para disputar o pleito majoritário. Naturalmente, não se aplica tal interpretação diante da inexistência de coligação majoritária;

3. A impossibilidade de se estabelecerem plurais coligações para eleição majoritária, tal como coligação diversa para Governador e Senador. Assim, a título de exemplo dado pelo Tribunal, "se seis partidos constituírem coligação ao pleito de Governador, não será viável, por exemplo, que, apenas quatro dentre esses partidos políticos formem coligação diferente para a disputa majoritária do cargo de Senador."

${ }^{157}$ TSE, Res. N. 20.121 e 20.126, rel. Min. Néri da Silveira, 12.03.98, DJ 16.04.98. 
4. Todavia, não se impede que cada partido tenha (ou não) candidato próprio ao Senado, coligando-se apenas para o pleito do cargo de Governador ou vice-versa.

Dada a interpretação atribuída pela Corte Eleitoral à Lei N. 9.504/97, nota-se que, apesar da ampla abertura criada pela lei, alguns parâmetros hermeneuticamente estabelecidos denotam a preocupação em se fechar a composição ideológica que fundamenta as eleições majoritárias. A partir dessas, restará determinada a possibilidade ou não dos partidos arquitetarem diferentes arranjos para o certame proporcional, "como for da conveniência de cada um, dentro da circunscrição"- frise-se tal como prevê a Resolução do TSE N. 20.121/98. Ao contrário, estando firmado o ajuste para o pleito majoritário, não se admite neste a pluralidade de coligações. Engessada fica a posição a ser assumida para qualquer pleito dessa natureza - cargos para Presidente, VicePresidente, Governador, Senadores e Prefeitos. Conclui-se, do exposto, que para o certame do ano de 1998, não se havia cogitado da verticalização das coligações, mantendo-se a autonomia partidária para celebrá-las, restringidas apenas aos limites literais impostos pela lei. Não somente não se falava em verticalização, como o TSE expressamente entendeu facultada a coligação diversa entre os níveis federais e estaduais, mantendo-se apenas a exigência de que estas se criassem "dentro os partidos que formam a coligação para eleição majoritária", como decorre estritamente do texto da Lei N. 9.504/97.

\subsubsection{Resolução N. 21.002 do $\quad$ TSE - A instituição da verticalização via regulamento}

Com a proximidade das eleições presidenciais de 2002, novamente seria o TSE instado a pronunciar-se acerca das coligações mediante resposta à Consulta N. 715/02, formulada em 10 de agosto de 2001 por Deputados do PDT. A indagação consistia na permissibilidade de um partido "A" celebrar coligação para eleição de Presidente da República com outros partidos ("B, C e D”) e, ao mesmo tempo, firmar coligação com terceiros partidos ("E, F e G"), que também possuem candidato à Presidência da República, com vistas às eleições para o cargo de Governador ${ }^{158}$.

${ }^{158}$ TSE, Consulta N. 715/DF e Res. N. 21.002, rel. Min. Garcia Vieira, 26.02.02, DJ 15.03.02. 
A resposta do TSE à Consulta N. 715/02 foi negativa, vencendo a posição majoritária do relator Ministro Garcia Vieira. Interpretando que o Tribunal Superior Eleitoral já havia se pronunciado sobre a questão, fundamentou sua posição na precedente Resolução N. 20.126/98 do TSE (analisada no tópico imediatamente anterior). Para o Ministro Garcia, considerado o caráter nacional dos partidos políticos exigido pela Constituição Federal em seu art. 17, inciso I, não haveria de se permitir coligações diversas da estabelecida para a eleição presidencial.

É de se notar que a Resolução N. 20.126/98, na qual se apoia o Ministro relator, não previu qualquer vinculação entre os níveis federais e estaduais para as eleições proporcionais. Tratou-se apenas de eleições disputadas dentro das circunscrições estaduais, ou seja, "dentro da mesma circunscrição". A decisão de 1998, que se ateve tão somente ao texto legal, inadmitiu diferentes coligações para eleições majoritárias, de modo que estariam vinculados a uma só coligação apenas os pleitos para Governadores e Senadores. Nada vincularia, nesse sentido, a candidatura à Presidência - de circunscrição nacional - às coligações a Deputado Federal ou Estadual ou a de Governadores e Senadores, feitas na circunscrição de cada Estado. Em outras palavras, inexistia qualquer vinculação obrigatória.

Da resposta à Consulta N. 715/02 resultaria a edição da Resolução N. 21.002 em 26 de fevereiro de 2002, cuja ementa resumiu a nova posição da Corte Eleitoral:

\begin{abstract}
"Consulta. Coligações. Os partidos políticos que ajustarem coligação para eleição de presidente da República não poderão formar coligações para eleição de governador de estado ou Distrito Federal, senador, deputado federal e deputado estadual ou distrital com outros partidos políticos que tenham, isoladamente ou em aliança diversa, lançado candidato à eleição presidencial. Consulta respondida negativamente.” 159
\end{abstract}

Em divergência minoritária, o Ministro Sepúlveda Pertence, ladeado por seu par, o Ministro Sálvio Figueiredo, e acolhendo parecer do Ministério Público Eleitoral, advertiu inicialmente sobre a incompetência do TSE de se sobrepor ao legislador e abandonar tanto a Norma Superior, a quem deve obediência, quanto o texto da legislação eleitoral. Segundo Pertence, não poderia a Corte Eleitoral

\footnotetext{
${ }^{159}$ A ementa citada viria a constar do art. 4, § $1^{\circ}$., Instrução N. 55 do TSE, veiculada pela Res. N. 20.993, também de 26 de fevereiro de 2002. Esta Resolução ficou conhecida como o regulamento que introduziu o fenômeno da verticalização em nosso ordenamento jurídico. TSE, Res. N. 20.993, rel. Min. Fernando Neves, 26.02.02, DJ 12.03.02; TSE, Consulta N. 715/DF e Res. N. 21.002, rel. Min. Garcia Vieira, 26.02.02, DJ 15.03.02.
} 
"se deixar envolver na polêmica, que vem agitando homens públicos e jornalistas políticos sobre se seria ou não conveniente que se viesse a impor a simetria ou a coerência entre as coligações que se constituíssem para a disputa da eleição presidencial e as que se formassem para as eleições majoritárias e proporcionais a serem travadas no âmbito de cada Estado-membro." 160

Conforme asseverou o Ministro, “antes é preciso saber se o problema já encontra solução unívoca na legislação eleitoral.” Respondendo de pronto positivamente a sua indagação, o Ministro Sepúlveda Pertence entendeu constar o desenlace da questão do próprio texto da Lei N. 9.504/97. O Ministro atribuiu à expressão "dentro da mesma circunscrição" - parte do caput do art. $6^{\circ}$. da Lei das Eleições - interpretação fundamentada no conceito de "circunscrição" trazido pelo Código Eleitoral: "Lei N. 4.737/65. Art. 86. Nas eleições presidenciais, a circunscrição será o país; nas eleições federais e estaduais, o Estado; e, nas municipais, o respectivo município."

Para o Ministro Pertence, a entidade "circunscrição" é eminentemente jurídica. Não se poderia, apenas pelo fato das eleições presidenciais se realizarem concomitantemente às federais e estaduais nas circunscrições de cada Estado, tomar-se o conceito de "circunscrição" em sentido meramente geográfico, de modo a transpor a vedação incidente para a eleição presidencial, na circunscrição "país", para a circunscrição "estado", que se presta a regular a eleição de Governadores, Senadores e Deputados. Ao assim fazer, instalava-se, de modo autoritário, de "cima para baixo", a verticalização de coligações, considerando-se, erroneamente, que a circunscrição "país" abrange a circunscrição "estado". A superposição territorial "não desmente a recíproca impermeabilidade jurídica das três circunscrições". Assim resumiu o Ministro Pertence: "Vale dizer que a Lei não permite inferir, da coligação entre determinadas agremiações para eleição presidencial, a vedação de que delas venha a se coligar com partidos diferentes para as eleições estaduais a realizarem-se simultaneamente." ${ }^{161}$ Realçando o entendimento sobre as circunscrições, que se coaduna - este sim - com a posição adotada pelo TSE em 1998, afirmou o Ministro:

\footnotetext{
"Ora, no sistema brasileiro, só há uma eleição de âmbito nacional - aquela para Presidente da República, (...) do que resulta que, com relação a ela, o art. $6^{\circ}$. da L. 9504/97 só contém uma regra, a da liberdade da formação de coligações para disputá-la, da composição das quais não advém restrição alguma a que os partidos respectivos venham a disputar em outra circunscrição - vale dizer, normalmente, na de cada um dos
}

\footnotetext{
${ }^{160}$ Voto proferido pelo Ministro Sepúlveda Pertence. TSE, Consulta N. 715/DF e Res. N. 21.002, rel. Min. Garcia Vieira, 26.02.02, DJ 15.03.02.

${ }^{161}$ TSE, Consulta N. 715/DF e Res. N. 21.002, rel. Min. Garcia Vieira, 26.02.02, DJ 15.03.02.
} 
Estados e do Distrito Federal - as eleições locais, isoladamente ou coligados a partidos diversos dos seus aliados nacionais." 162

Nesse sentido, o Ministro Sepúlveda atacou frontalmente a posição do então Presidente da Corte Eleitoral, Ministro Nelson Jobim, para quem as circunscrições eram como círculos concêntricos na "teoria dos conjuntos", "a maior abrangendo as menores" $" 163$.

Em oposição ao Ministro Jobim, na visão do Ministro Sepúlveda Pertence, equivocada estaria a premissa de que todas as eleições majoritárias (Presidente, Governadores e Senadores) ocorriam dentro da uma mesma circunscrição, pois, do contrário, restaria ociosa a expressão contida no art. $6^{\circ}$. da Lei N. 9.504/97 "dentro da mesma circunscrição".

Já para o Ministro Jobim, aderente à corrente majoritária então formada ${ }^{164}$, a chave da questão residia no "caráter nacional" dos partidos políticos, constitucionalmente colocado no art. 17. No seu douto entender, qualquer combinação regional assimétrica à presidencial fere a natureza de abrangência nacional imposta aos partidos, que foi uma opção do ordenamento pátrio para o fortalecimento dessas instituições políticas. Interpretando também a expressão "dentro da mesma circunscrição" de forma diversa ao Ministro Pertence, o Ministro Jobim chega a conclusões diametralmente opostas ao seu colega: o termo seria inútil se não aplicado à relação entre coligações nacionais e estaduais, de modo a vincular as últimas às primeiras, que possuem maior abrangência e conferem o caráter nacional aos acordos políticos firmados para disputa dos pleitos eleitorais.

As posições extremadas dos Ministros geraram interessante debate, valioso de se trazer à baila. Assim, para o Ministro Sepúlveda Pertence, a verticalização constituía um "resíduo autoritário" que diminui a "clara opção constitucional pela autonomia dos partidos”, não passível de ser reduzida pela lei, ainda mais por interpretação jurídica. A relevância constitucional da autonomia dos partidos se resume nas palavras de

\footnotetext{
162 TSE, Consulta N. 715/DF e Res. N. 21.002, rel. Min. Garcia Vieira, 26.02.02, DJ 15.03.02.

163 Acompanhou o raciocínio do Ministro Jobim o ilustre Ministro Fernando Neves, para quem não resta dúvida que "as eleições estaduais (Governadores, Senadores, Deputados) se realizam dentro da circunscrição da eleição presidencial, que é o país". "Há um circunscrição menor, contida em uma maior", concluiu Neves. TSE, Consulta N. 715/DF e Res. N. 21.002, rel. Min. Garcia Vieira, 26.02.02, DJ 15.03.02.

${ }^{164}$ Votariam com o relator e o Presidente do TSE, a Ministra Ellen Gracie e os Ministros Fernando Neves e Luiz Carlos Madeira, tendo também manifestado divergência o Ministro Sálvio de Figueiredo Teixeira. TSE, Consulta N. 715/DF e Res. N. 21.002, rel. Min. Garcia Vieira, 26.02.02, DJ 15.03.02.
} 
J. AfONSO DA Silva, que claramente lhe atribui maior peso vis a vis ao princípio da coerência na formação das coligações ${ }^{165}$. Diz o doutrinador:

\begin{abstract}
"Destaque-se aí o princípio da autonomia partidária, que é uma conquista sem precedente, de tal sorte que a lei tem muito pouco a fazer em matéria de estrutura interna, organização e funcionamento dos partidos. Estes podem (...) adotar os critérios de escolha e o regime de suas coligações eleitorais, sem obrigatoriedade de vinculação entre as candidaturas em âmbito nacional, estadual, distrital ou municipal." 166
\end{abstract}

O Ministro Sepúlveda Pertence identificou ainda afronta ao pluralismo político na opção pela verticalização. Ora, quer-se crer que a pluralidade é um dos fundamentos da República brasileira contida na Lei Fundamental em seu artigo primeiro e princípio basilar do Estado Democrático. Juntamente com o Ministro Pertence, não consigo enxergar diversamente, até porque, como será analisado ainda neste capítulo, por diversas vezes e contemporaneamente, as Cortes Maiores se pronunciaram em favor da preservação da maior autonomia partidária ${ }^{167}$, como na decisão sobre a não imposição da cláusula de barreira. Reside razão ao Ministro Pertence, que alertou sobre o estímulo à dissimulação e à perda da transparência do processo eleitoral resultante da decisão tomada em nome do fortalecimento do 'caráter nacional' dos partidos. Diz o Ministro ter aprendido "como as forças políticas reais sabem compor-se, contra ou apesar da lei e dos tribunais". Não poderia ter sido mais feliz em sua observação o Ministro Pertence. Uma das grandes mazelas de nosso sistema legislativo é a inflação de normas que buscam regular condutas de modo distanciado da realidade posta. Ao renegar a observação do modo de proceder instaurado no seio da sociedade, o legislador - e o intérprete - que procura enquadrar condutas consuetudinárias e valores já arraigados no seio social, produz a chamada "lei de letra morta", a norma inaplicável, contornável, impossível de ser respeitada. Em que pese a figura da verticalização, os compromissos políticos foram firmados volitivamente pelos partidos. Pior: a obrigatoriedade forçou composições ideologicamente assimétricas ${ }^{168}$, ao

\footnotetext{
${ }^{165}$ Cf. voto do Ministro Fernando Neves, as coligações devem seguir a certa lógica: "quem é adversário em uma eleição nacional não pode ser aliado em outra, regional, incluída na circunscrição da primeira." TSE, Consulta N. 715/DF e Res. N. 21.002, rel. Min. Garcia Vieira, 26.02.02, DJ 15.03.02. O enunciado viria a ser conhecido como o "princípio da coerência na formação das coligações", criado pela corrente majoritária em torno do tema das coligações e que se formou no TSE em 2002. Cf. A. DE MoRAES, Direito Constitucional, $23^{\mathrm{a}}$. ed., São Paulo, Atlas, 2008, p. 263.

${ }^{166}$ J. AFONSO DA SILVA, Curso de direito constitucional positivo, cit., p. 405-406.

${ }^{167}$ Vide, e.g., STF, Pleno, ADI N. 1.351, rel. Min. Marco Aurélio, 07.12.06, DJ 30.03.07; TSE, Consulta N. 1.251/DF e Res. N. 22.213, rel. Min. Carlos Britto, 30.05.06, DJ 20.06.06.

${ }^{168}$ Vide, a título de exemplo, a atração oferecida pelo PT nas eleições de 2006, uma vez que ocupava o cargo presidencial, aos partidos como PMDB, PL, PTB e PP, que distantes estavam da esquerda estremada que a ideologia do PT sempre propagou. O exemplo desmente o argumento da Ministra Ellen Gracie, para quem, referindo-se ao julgado de 2002 em resposta à Consulta N. 715/DF, "esta interpretação sinaliza no sentido da
} 
contrário do que pretendia evitar a corrente majoritária. Em busca de alcançar cargos junto ao governo, partidos que historicamente não guardavam qualquer afinidade, com programas de governo antagônicos, viriam a se associar necessariamente nos Estados aos seus pares nacionais.

A decisão, dada em nome do fortalecimento partidário, pouco haveria de alcançar seus objetivos. Tal fracasso se repetirá, ao menos, na decisão sobre a fidelidade partidária, como será examinado no capítulo seguinte. Imposta judicialmente a fidelidade visando encorpar e moralizar o sistema partidário, pouco sucesso alcança, à medida que os parlamentares buscam formas de contorná-la e de tornar a decisão do Supremo sem qualquer efetividade. Mas isso é assunto para o próximo capítulo.

\subsubsection{Ilegalidade e inconstitucionalidade do regulamento do TSE}

A observância da vinculação vertical das coligações passou ser obrigatória para as eleições de 2002, a partir da decisão tomada pelo TSE em resposta à Consulta N. 715/02 supra analisada. A regulamentação do instituto constou do art. $4, \S 1^{\circ}$., Instrução N. 55 do TSE, veiculada pela Resolução N. 20.993/02, com base na decisão resumida na Resolução N. 21.002/02 da mesma Corte.

Ocorre que, na data da decisão e regulamentação (final de fevereiro de 2002), estava-se apenas a sete meses do certame eleitoral nacional. Embora ao TSE se facultasse regular as eleições até o dia 5 de março do ano eleitoral, deve-se atentar que a Corte foi além da simples regulamentação prevista no ordenamento. O Tribunal Eleitoral havia introduzido, ainda que por meio da atividade hermenêutica, novo entendimento ou nova espécie a alterar as regras do jogo eleitoral, em momento que os partidos já haviam formatado, ainda que incipientemente, seu quadro de candidatos e ajustes políticos nos Estados e no país. A mudança de entendimento - como será enfaticamente repetido neste trabalho - causa extrema confusão e insegurança jurídica às instituições democráticas. Afeta, mormente, o processo eleitoral já iniciado. Mas não é só. Ofende, como é sabido, o princípio da anualidade da lei eleitoral - continuamente visitado neste estudo - pelo qual o 
constituinte buscou garantir estabilidade nas regras desse importante elemento do jogo da democracia.

$$
\text { Como bem relembra Monica Herman SAlem CAggiano, }{ }^{169} \text { agiu a }
$$

Corte Eleitoral da mesma maneira em que atuou na limitação ao número de Vereadores durante o ano eleitoral de 2004, ignorando o dispositivo do art. $16 \mathrm{CF} / 88$, e mais: utilizouse de ato normativo secundário para criar nova norma a regular o pleito eleitoral, sobrepondo-se às funções do legislador, ferindo a legalidade estrita, pela qual somente o ato normativo primário, de competência do Legislativo, deve produzir normas. As Instruções emitidas pelo TSE encontram-se na esfera do poder regulamentar, de modo que jamais deverão extrapolar os termos do ordenamento objeto de regulamentação. Professo, então, que me filio à corrente do Ministro Pertence, que entende haver o TSE transgredido ao postulado constitucional da reserva da lei. Na verdade, o entendimento do Supremo aponta que a Corte incidiu, neste item, em ilegalidade - e não inconstitucionalidade, pois como asseverou o Ministro Velloso na ADI N. 589/DF: "Se o ato regulamentar vai além do conteúdo da lei, pratica ilegalidade. Neste caso, não há falar em inconstitucionalidade" ${ }^{170}$.

De qualquer modo, novamente vislumbra-se o atentado à separação dos Poderes e marca-se novo exemplo de ativismo do Judiciário, desta feita em consequência da "força normativa da Justiça Eleitoral." ${ }^{171}$ Mas seria esse o entendimento da Suprema Corte?

\footnotetext{
${ }^{169}$ M. HERMAN SALEM CAGGIANO, Legislação eleitoral e hermenêutica política x segurança jurídica, cit. ${ }^{170}$ STF, Pleno, ADI N. 589/DF, Rel. Min. Carlos Velloso, 20.09.91, DJ 18.10.91.A decisão ainda contava com precedentes do STF, onde ficou assentado que ato normativo de natureza regulamentar que excede o conteúdo da lei não se sujeita ao controle concentrado. STF, Pleno, ADI N. 311, Rel. Min. Carlos Velloso, 08.08.1990, DJ 14-09-1990; STF, Pleno, ADI N. 536/DF, Rel. Min. Carlos Velloso, 08.08.91, DJ 13.09.91. ${ }^{171}$ O termo é empregado por M. HERMAN SALEM CAGGIANO, para mostrar que, nos últimos anos, o TSE se esmera em sua produção normativa, regulando com impressionante frequência matéria eleitoral, via interpretação e atos secundários (Resoluções). Cf. M. HERMAN SALEM CAGGIANO, A jurisprudência constitucional sobre matéria eleitoral, disponível (on line) in http://www.mackenzie.br/fileadmin/Graduacao/ FDir/Artigos_2008/Controle_de_consti_2008_processo_constitucional_publ_mackenzie.pdf., [ 25.05.08].
} 


\subsubsection{ADI N. 2.626 e ADI N. 2.628 - O questionamento da atividade normativa do TSE}

A regulamentação do TSE por meio das Resoluções editadas em fevereiro de $2002^{172}$ não pacificara a tensão existente em torno do tema coligações. A Suprema Corte seria provocada para se pronunciar nas ADI N. 2.626 e N. $2.628^{173}$, o que faria de maneira simultânea em abril de 2002. Alegaram os proponentes ${ }^{174}$ a inconstitucionalidade do $\S 1^{\circ}$. do art. $4^{\circ}$. da Instrução N. 55, aprovada pela Resolução N. 20.993/02, por ofensa aos art. $5^{\circ}$. II e LIV, 16, 17 § $1^{\circ}$., 22, I e 48 da Constituição Federal. Para os partidos que acionaram o STF, a norma impugnada afetava a todos os partidos políticos ao promover mudanças no processo eleitoral, ao introduzir vedação jurídica de que o Poder Legislativo não cogitara. Tal fato configuraria o caráter autônomo, abstrato e geral do ato normativo do TSE, a ensejar controle abstrato pela Corte Guardiã.

Ambas as ações diretas de constitucionalidade não foram conhecidas pelo STF, que entendeu, majoritariamente, que o dispositivo impugnado era resultante de interpretação do TSE, fruto de resposta à Consulta regularmente proposta. Assim considerando, não caberia ao Supremo julgar excesso de interpretação. Além do mais, entendeu a maior parte dos Ministros do STF que inexistia qualquer dispositivo constitucional a regular diretamente as coligações partidárias - o que se processava por meio de lei federal - restando, deste modo, inviável o exame da matéria pelo Tribunal guardião da Constituição. A posição que viria a prevalecer majoritariamente no julgamento da ADI N. $2.626^{175}$, tinha como base diversos precedentes ${ }^{176}$, entre as quais o mais contemporâneo é o retratado na ementa da ADI N. 2.243, ajuizada contra a Resolução N. 20.562/00 do TSE ${ }^{177}$ :

172 TSE, Res. N. 20.993, rel. Min. Fernando Neves, 26.02.02, DJ 12.03.02; TSE, Consulta N. 715/DF e Res. N. 21.002, rel. Min. Garcia Vieira, 26.02.02, DJ 15.03.02.

${ }^{173}$ STF, Pleno, ADI N. 2.626 e N. 2.628, rel. ac. Min. Ellen Gracie, 18.04.02, DJ 05.03.04.

${ }^{174}$ As citadas ações foram proposta pelos seguintes partidos: ADI N. 2.626 - PC do B, PT, PSB e PL e ADI N. 2.628 - PFL. STF, Pleno, ADI N. 2.626 e N. 2.628, rel. ac. Min. Ellen Gracie, 18.04.02, DJ 05.03.04.

${ }^{175}$ Formaram a corrente majoritária a Ministra relatora para o acórdão, Ellen Gracie e os Ministros Moreira Alves, Néri da Silveira, Sydney Sanches, Celso de Mello, Carlos Velloso, Maurício Corrêa, Nelson Jobim, sendo que apenas o Ministro Jobim e a Ministra Gracie haviam votado, quando no TSE, na decisão em resposta à Consulta N. 715/DF, a favor da instituição da verticalização. STF, Pleno, ADI N. 2.626 e N. 2.628, rel. ac. Min. Ellen Gracie, 18.04.02, DJ 05.03.04.

${ }^{176}$ Cf. STF, Pleno, ADI N. 2.243, rel. Min. Marco Aurélio, 16.08.00, DJ 06.06.03; STF, Pleno, ADI-MC N. 1.900, rel. Min. Moreira Alves, 05.05.99, DJ 25.02.00; STF, Pleno, ADI-MC N. 147, rel. Min. Carlos Madeira, 24.11.89, DJ 09.02.90.

${ }^{177}$ TSE, Res. N. 20.562, rel. Min. José Eduardo Rangel de Alckmin, 02.03.00, DJ 27.03.00. 
“(...) o controle concentrado de constitucionalidade pressupõe descompasso de certa norma com o Texto Fundamental, mostrando-se inadequado para impugnar-se ato regulamentador, como é a Resolução N. 20.562 do Tribunal Superior Eleitoral, de 2 de março de 2000, sobre a distribuição dos horários de propaganda eleitoral, versada na Lei N. 9.504/97." 178

No mesmo sentido, empregou-se a decisão proferida na ADI N. 1.822 para justificar o não conhecimento da ação, cuja ementa versava:

"Em se tratando de instrução do TSE que se limita a reproduzir dispositivos da Lei N. 9.504/97 também impugnados, a argüição relativa a essa instrução se situa apenas mediatamente no âmbito da constitucionalidade, razão por que não se conhece da presente ação nesse ponto." 179 (grifos nossos)

De semelhante compreensão compartilhou o Ministro Carlos Velloso, para quem a Instrução Normativa N. 55 do TSE era ato normativo secundário, decorrente de ato normativo primário contido no art. $6^{\circ}$. da Lei N. 9.504/97 e autorizado pelo art. 105 da própria Lei das Eleições. Além do mais, frisou o Ministro Velloso a jurisprudência Suprema a indicar que o ato regulamentar não está sujeito, via de regra, ao controle concentrado, uma vez que seu excesso enseja ilegalidade. Em igual sentido, para o Ministro Celso de Mello, o ato impugnado veiculava conteúdo meramente interpretativo, resultante de regular exercício de competência do $\operatorname{TSE}^{180}$.

De outro lado, há entendimento oposto igualmente fundado em orientação jurisprudencial da Suprema Corte, favorável ao cabimento do controle concentrado de Instruções emitidas pelos Tribunais Eleitorais ${ }^{181}$. Nesse sentido foi emitido o parecer por Geraldo Brindeiro, Procurador Geral da República nos autos da ADI em exame. Note-se que o Procurador também se apoia, para fundamentar seu entendimento divergente, na ADI N. 1.822 (cuja ementa foi transcrita acima). Brindeiro alertou para diversas suspensões aplicadas pelo Excelso Pretório ${ }^{182}$ às Resoluções do TSE que versaram

178 A citada Resolução tratou da distribuição de tempo para a propaganda eleitoral gratuita entre os candidatos das coligações. Na ocasião, o Supremo não conheceu da ADI. Cf. STF, Pleno, ADI N. 2.243, rel. Min. Marco Aurélio, 16.08.00, DJ 06.06.03.

${ }^{179}$ STF, Pleno, ADI N. 1.822/DF, rel. Min. Moreira Alves, 26.06.98, DJ 10.12.99.

${ }^{180}$ STF, Pleno, ADI N. 2.626 e N. 2.628, rel. ac. Min. Ellen Gracie, 18.04.02, DJ 05.03.04.

${ }^{181}$ Cf. STF, Pleno, ADI N. 2.280/RS, rel. Min. Joaquim Barbosa, 27.09.06, DJ 24.11.06; STF, Pleno, ADI N. 2.275/PA, rel. Min. Maurício Corrêa, 07.08.02, DJ 13.09.02; STF, Pleno, ADI N. 2.265/RR, rel. Min. Marco Aurélio, 28.09.00, DJ 07.12.00; STF, Pleno, ADI N. 1.822/DF, rel. Min. Moreira Alves, 26.06.98, DJ 10.12.99; STF, Pleno, ADI N. 1.710/AL, rel. Min. Sydney Sanches, 03.03.99, DJ 03.09.99; STF, Pleno, ADI N. 696/DF, rel. Min. Sydney Sanches, 20.09.95, DJ 20.10.95.

${ }^{182}$ V., e.g., STF, Pleno, ADI-MC N. 1.407/DF, rel. Min. Celso de Mello, 07.03.96, DJ 24.11.00; STF, Pleno, ADI N. 1.710/AL, rel. Min. Sydney Sanches, 03.03.99, DJ 03.09.99; STF, Pleno, ADI-MC N. 1.787/PE, rel. Min. Moreira Alves, 26.02.98, DJ 03.04.98. V. também as ADI citadas na nota imediatamente superior. 
normas de caráter abstrato e geral, violando a legalidade e usurpando competência legislativa do Congresso Nacional.

Conclui-se do observado que a divergência do posicionamento dos Ministros se subsume a saber se houve ou não mero ato interpretativo do dispositivo legal existente ou se por meio da interpretação, criou-se normas no campo eleitoral. Não se entendendo pela inovação e sim pela edição de mero regulamento, ou estando-se diante de “instrução do TSE que se limita a reproduzir dispositivos da lei”, não haveria de se falar em controle de constitucionalidade. Pelo simples excesso de poder regulamentar do TSE, já havia se pronunciado o STF no sentido de ser necessário primeiramente confrontar o ato impugnado com a norma infraconstitucional, o que configuraria ofensa indireta ou reflexa à Constituição, não passível de exame de constitucionalidade. A jurisprudência do STF inadmite o conhecimento de ações por inconstitucionalidade reflexa ${ }^{183}$.

Todavia, cabível seria o controle abstrato se efetivamente o Supremo entendesse que houve criação de norma contrária ao texto constitucional ou ofensiva aos seus princípios, pois então agiria como guardião da Carta Régia. Nessa linha de idéias, um dos fundamentos da ação em tela é a afronta ao princípio da anterioridade eleitoral, questão esta limpidamente constitucional. Para a corrente minoritária ${ }^{184}$, que entende ter ocorrido mudança no posicionamento do TSE na Resolução N. 21.002/02 em face das Resoluções N. $20.121 / 98$ e N. $20.126 / 98$ - o que efetivamente se processou, conforme se procurou demonstrar nesse capítulo - não há como negar que houve alteração da matéria eleitoral no período de carência constitucional. Tanto assim que para as eleições gerais de 1998 não prevaleceu qualquer vinculação à candidatura nacional. Foi por intermédio de decisão do TSE em 2002 - seja qual for a natureza dessa: ato normativo primário ou secundário - que a verticalização viria a ser implantada.

Adentrando-se na questão de eventual ativismo do legislador da Corte Eleitoral, não vejo razões para não compartilhar do argumento da douta Procuradoria Geral da República, apenso aos autos da ADI N. 2.626, pelo qual:

\footnotetext{
${ }^{183}$ STF, Pleno, ADI-MC N. 1.900, rel. Min. Moreira Alves, 05.05.99, DJ 25.02.00; STF, Pleno, ADI-MC N. 1.347, rel. Min. Celso de Mello, 05.09.95, DJ 01.12.95.

${ }^{184}$ V. voto do Ministro Sepúlveda Pertence, que compara a decisão do TSE de 1998 com o resultado do julgamento de 2002 e conclui que houve real "inovação no bloco da regulamentação de lei eleitoral". Acompanharam a divergência no julgamento da ADI N. 2.626 os Ministros Ilmar Galvão, Marco Aurélio e o Ministro relator original Sydney Sanches. STF, Pleno, ADI N. 2.626 e N. 2.628, rel. ac. Min. Ellen Gracie, 18.04.02, DJ 05.03.04.
} 
"Ocorre, na espécie, todavia, autêntica atividade legislativa realizada por Poder outro, a Justiça Eleitoral, ao editar norma em tudo dissociada da expressão volitiva do legislador, enfim, de sua pretensa fonte legal, a qual deveria, quando muito, regulamentar." 185

O Ministro relator Sydney Sanches, apoiando-se nos votos vencidos dos Ministros Pertence e Figueiredo na resposta à Consulta N. 715/02, entendeu pelo conhecimento da ADI por ter o TSE legislado positivamente. Julgou, deste modo, procedente a inconstitucionalidade do art. $4^{\circ}$., $\S 1^{\circ}$., da Instrução N. 55 do TSE, com eficácia ex tunc. E como bem observou o relator original, em se tratando de regulamento para as eleições de 2002, a referida Instrução não poderia se estender aos pleitos vindouros $^{186}$.

Restou, todavia, vencido o Ministro Sanches, razão pela qual foi substituído pela Ministra Gracie na relatoria do acórdão, que, por não conhecer da ação, manteve a vigência da figura da verticalização para o pleito de 2002.

\subsubsection{Resolução N. 21.474 do TSE - Municípios excluídos da verticalização}

Com a proximidade dos pleitos eleitorais municipais de 2004, tornaria o TSE a ser consultado sobre a aplicação da verticalização das coligações. A Consulta N. 901/DF trouxe a indagação sobre a possibilidade de se firmarem alianças diferenciadas nos Municípios do mesmo Estado federativo. A decisão unânime levou em consideração o estrito conceito de circunscrição eleitoral e asseverou:

"Nas eleições municipais, o eleitor vota somente em cargos da mesma circunscrição,
razão pela qual não incidirá o princípio da coerência na formação de coligações, que
impede que partidos adversários na circunscrição nacional sejam aliados nas
circunscrições estaduais." 187
O julgamento, resumido na Resolução N. 21.474 , manteve a interpretação majoritária atribuída ao conceito "dentro da mesma circunscrição" pelo Tribunal na Resolução N. 21.002/02. A verticalização foi fundamentada na "teoria dos

\footnotetext{
${ }^{185}$ STF, Pleno, ADI N. 2.626 e N. 2.628, rel. ac. Min. Ellen Gracie, 18.04.02, DJ 05.03.04.

${ }^{186}$ STF, Pleno, ADI N. 2.626 e N. 2.628, rel. ac. Min. Ellen Gracie, 18.04.02, DJ 05.03.04.

187 TSE, Consulta N. 901/DF e Res. N. 21.474, rel. Min. Fernando Neves, 26.08.03, DJ 03.10.03.
} 
conjuntos" - termos do Ministro Jobim - que reflete a figura dos círculos concêntricos ${ }^{188}$. À época do julgamento da Consulta N. 715/02, o Ministro Jobim afirmara que "o problema não se põe na eleição municipal", pois "ela é uma "eleição solteira'."189 A assertiva de Ministro Jobim não ilidira - aliás, agravara - a eterna questão: por que haveria da circunscrição municipal de não estar contida na estadual, mas esta sim abrangida pela nacional? Em se contendo as municipais nas demais circunscrições, por que não sujeita à verticalização?

Nesse ponto se demonstra que razão residia ao Ministro Pertence ${ }^{190}$ ao alertar que o entendimento dos tais "círculos concêntricos" confundia o sentido jurídico com o geográfico e erroneamente tomava o conceito de "mesma", a qualificar o substantivo "circunscrição", como referente à coincidência temporal, ou seja, à simultaneidade observada entre as eleições presidenciais e aquelas destinadas à escolha de Governadores, Senadores e Deputados. Ainda assim, o TSE respondeu positivamente à Consulta, entendendo inexistir o vínculo obrigatório afeto às coligações no certame eleitoral municipal.

\subsubsection{Emenda Constitucional N. 52/06 - O Congresso reverte a decisão judicial}

Aplicada às eleições gerais de 2002 e excluída dos pleitos municipais de 2004, a regra da verticalização foi novamente questionada com a proximidade das eleições gerais de 2006.

Inicialmente, e com menor destaque, retomaram-se os debates a respeito da obrigatoriedade da vinculação das coligações ao paradigma nacional. Em fevereiro de 2005, o TSE voltou a se manifestar por ocasião da Petição N. 1.591/DF, colocada pelo Deputado João Caldas, que requereu fosse declarado insubsistente o princípio da coerência das coligações para as eleições de 2006, em face da aprovação do projeto de Lei N. 6256A/2002 na Comissão de Constituição e Justiça e Cidadania em novembro de 2004. A Corte

\footnotetext{
${ }^{188}$ V. TSE, Consulta N. 715/DF e Res. N. 21.002, rel. Min. Garcia Vieira, 26.02.02, DJ 15.03.02. Cf. p. 75 deste trabalho onde se traz a explicação dos Ministros Jobim e Neves sobre o conceito de "circunscrição" adotado majoritariamente pelo TSE em 2002.

${ }^{189}$ TSE, Consulta N. 715/DF e Res. N. 21.002, rel. Min. Garcia Vieira, 26.02.02, DJ 15.03.02.

190 TSE, Consulta N. 715/DF e Res. N. 21.002, rel. Min. Garcia Vieira, 26.02.02, DJ 15.03.02.
} 
entendeu não ser projeto de lei hábil a motivar mudança na orientação fixada em Resolução daquele Tribunal. ${ }^{191}$

Visando reformar a posição do TSE, o PSL (Partido Social Liberal) questionou a Corte em março de 2006 sobre a manutenção da verticalização para o certame do mesmo ano. A Consulta N. 1185/DF foi formulada solicitando autorização para formação de coligações estaduais híbridas, que não se vinculassem ao paradigma nacional. Sem dúvida o questionamento era dotado de legitimidade e pertinência, pois, além de ser formulado em tese, sobre matéria eleitoral, deve-se recordar que a Instrução N. 55, que introduzira a verticalização no ordenamento, regulava apenas as eleições de 2002. Acrescente-se, ainda, que o proponente acreditava ser possível nova mudança de posicionamento dos Tribunais Eleitorais. Primeiramente, sua composição se renovara. Mas, principalmente, porque já se havia vivenciado as dificuldades causadas pela obrigatoriedade dos partidos de 27 Estados seguirem regionalmente o que determinaram as forças políticas formadas para disputa da presidência. A verticalização havia de fato imposto o entrelaçamento forçado dos interesses locais e regionais com as expectativas políticas nacionais, restringindo as opções aos eleitores.

O TSE decidiu então, em sessão de 3 de março de 2006, pela manutenção da vinculação das coligações para o certame eleitoral de outubro de 2006. Vencido o relator original, Ministro Marco Aurélio, que propugnou mudança no entendimento adotado em 2002 por prestígio à autonomia partidária, o Ministro Caputo Bastos foi designado relator para o acórdão. Entendendo estar valorizando a segurança jurídica ao manter o status quo, o Ministro Bastos optou por reafirmar o conteúdo da Resolução N. $20.993 / 02$, no que foi seguido pela maioria ${ }^{192}$. Lembrou, inclusive, que o Congresso Nacional tivera quatro anos para promover as mudanças que julgasse pertinentes. Porém, diante "da omissão legislativa, voluntária ou involuntária, o fato é que não houve mudança no ordenamento jurídico"193 , proferiu o Ministro Bastos.

Curioso saber que, desta feita, entendeu por bem a Corte Eleitoral que deveria aplicar o art. 16 da Carta Maior, para não alterar o entendimento majoritariamente firmado em 2002. Alegou o Ministro Caputo Bastos que, em conformidade com o art. 18

\footnotetext{
${ }^{191}$ V. TSE, Res. N. 21.986, rel. Min. Luiz Carlos Madeira, 15.02.05, DJ 30.05.05.

192 A maioria foi formada pelo Ministro relator designado, Caputo Bastos, ladeado pelos ilustres Ministros Gilmar Mendes (Presidente), Cezar Peluso, Humberto Gomes de Barros, Geraldo Grossi. Vencidos restaram os Ministros Marco Aurélio e Cesar Asfor Rocha. TSE, Res. N. 22.161, rel. Res. Min. Caputo Bastos, 03.03.06, DJ 24.04.06.

193 TSE, Res. N. 22.161 rel. Res. Min. Caputo Bastos, 03.03.06, DJ 24.04.06.
} 
da Lei N. 9.096/95, não se permitiriam mudanças de partidos. Logo, a verticalização fazia parte das regras do jogo, que não deveriam ser alteradas durante a anterioridade eleitoral do art. 16 da CF/88, pois "muitos cidadãos, ou mesmos detentores de mandato eletivo, tinham a real e efetiva expectativa de que a regra da verticalização estaria valendo para a eleição que se avizinha", entendeu o Ministro. Não custa repisar o óbvio: em 2002, a verticalização fora introduzida no ordenamento a sete meses do pleito, no mês de março. Para a corrente majoritária da época, não se cogitou de qualquer aplicação do princípio da anterioridade $^{194}$. Já em 2006, o mesmo princípio foi validado para impedir qualquer alteração na interpretação para as eleições próximas.

O início do mês de março de 2006 foi um tanto atribulado em matéria eleitoral. Enquanto o TSE formulava resposta à mencionada Consulta e editava a Resolução N. 22.161, a PEC N. 548, que tramitava desde 2002 no Congresso para superar a verticalização imposta pelo Tribunal naquela época, foi aprovada, dando ensejo à promulgação da EC-52/06, no dia 8 do mesmo mês. A reforma ao texto constitucional atingiu a redação do $\S 1^{\circ}$. do art. 17 , que passou a versar:

“Art. 17, $\$ 1^{\circ}$ É assegurada aos partidos políticos autonomia para definir sua estrutura interna, organização e funcionamento e para adotar os critérios de escolha e o regime de suas coligações eleitorais, sem obrigatoriedade de vinculação entre as candidaturas em âmbito nacional, estadual, distrital ou municipal, devendo seus estatutos estabelecer normas de disciplina e fidelidade partidária" (grifos nossos)

$\mathrm{O}$ art. $2^{\circ}$. da Emenda em exame determinava a aplicação de seus efeitos “às eleições que ocorrerão no ano de 2002" ${ }^{195}$. Retomava-se a plena autonomia para celebração de coligações em todas as esferas da federação de maneira desvinculada, contornando o entendimento fixado pelo TSE em 2002. Optou o legislador alçar a matéria - até então regulamentada por legislação ordinária - ao nível constitucional, ao invés de tão somente alterar a Lei das Eleições, extinguindo o instituto da verticalização.

\footnotetext{
${ }^{194}$ Embora a corrente majoritária do TSE formada em 2002 (Res. N. 21.002) entendesse estar apenas interpretando a Lei N. 9.504/97, de cujos dispositivos se extraía a verticalização das coligações, não havendo, em sua visão, mudança interpretativa, é bom recordar - conforme já frisado nesse capítulo - que não há como esconder a mudança nos rumos da interpretação da Corte, uma vez que o instituto não fora identificado na interpretação à lei conferida por ocasião das eleições gerais de 1998. TSE, Res. N. 20.121 e 20.126, rel. Min. Néri da Silveira, 12.03.98, DJ 16.04.98.

${ }^{195}$ Em que pese o art. $2^{\circ}$. da EC-52/06 prever a aplicação de seus efeitos "às eleições que ocorrerão no ano de 2002”, obviamente não propagaria suas mudanças sobre ato já consumado. Muito se elucubrou sobre o motivo do constituinte derivado ter optado por manter o ano de 2002 e não retocado o texto original da PEC (cuja elaboração e tramitação se iniciara em 2002). Falou-se em erro evidente. Insinuou-se, inclusive, haver tentativa de retroatividade visando "salvar" o pleito de 2006 da anterioridade. V. STF, Pleno, ADI N. 3.685, rel. Min. Ellen Gracie, 22.03.06, DJ 10.08.06.
} 


\subsubsection{ADI N. 3.685-O STF dá a última palavra}

A história voltaria a se repetir, tal como no debate da cláusula de barreira, no qual a decisão do Tribunal Eleitoral foi revertida pelo Congresso e em sequência, obstada pelo Supremo. Não seria diferente para a questão da verticalização. Em outras palavras, não foram as Casas Legislativas a dar a última palavra, mas sim o Supremo. Isso porque nova polêmica se instauraria a respeito da anterioridade constitucionalmente exigida para a vigência de novas regras eleitorais perante o pleito a se realizar em outubro do mesmo ano.

Um dia após a promulgação da Emenda N. 52, em 9 de março de 2006, a OAB propôs ADI no STF, que viria a julgá-la em duas semanas e publicá-la no último dia do mesmo mês. Agiu rapidamente a Corte Suprema visando evitar a propagação dos efeitos da reforma proposta, fixando, por maioria de votos, ${ }^{196}$ que o $\S 1^{\circ}$. do art. 17 supra transcrito não se aplicaria às eleições de 2006, remanescendo aplicável à tal eleição sua redação original, o que se traduz pela manutenção do instituto da verticalização das coligações no pleito de 2006. Uma vez definida pelo Supremo que a inovação trazida pela EC-52/06 somente se aplicaria depois de decorrido um ano da data de sua vigência, a liberdade de alianças partidárias em eleições gerais somente deverá ser observada em 2010.

De acordo com a Ministra relatora Ellen Gracie - no que foi acompanhada pela maioria - o emprego de nova regra às eleições gerais que se realizariam em menos de sete meses da introdução da medida, colide com o princípio da anterioridade eleitoral, que protege o processo eleitoral ${ }^{197}$ de mudanças casuísticas e manipuladoras.

\footnotetext{
${ }^{196}$ Foram votos vencidos os proferidos pelos Ministros Marco Aurélio e Sepúlveda Pertence, que mantiveram com coerência e constância seu entendimento - tanto no TSE quanto no STF - contra a vinculação obrigatória das coligações ao paradigma nacional. Para o Ministro Marco Aurélio, firme em sua posição de que o TSE introduzira a verticalização por ato interpretativo, professou em seu voto na ADI N. 3.685, estar "muito triste", pois o Congresso Nacional utilizou-se de Emenda Constitucional "para cassar simples interpretação do Tribunal Superior Eleitoral, banalizando-se, barateando-se (...) o instituto". STF, Pleno, ADI N. 3.685, rel. Min. Ellen Gracie, 22.03.06, DJ 10.08.06.

${ }^{197}$ De acordo com posicionamento pretérito do STF, o processo eleitoral engloba "as normas instrumentais diretamente ligadas às eleições, desde a fase inicial (a da apresentação das candidaturas) até a final (a da diplomação dos eleitos)". V. voto do Min. Moreira Alves in STF, Pleno, ADI N. 354, rel. Min. Octavio Galotti, 24.09.90, DJ 22.06.01. De outra face, S. Excelência, o Ministro Sepúlveda Pertence, entende o processo eleitoral em sua maior amplitude, que abrange "desde o alistamento dos eleitores e a habilitação dos partidos à escolha dos candidatos; (...) do registro dos candidatos à propaganda; da votação ao procedimento
} 
Trata-se, conforme reiteradamente se pronunciara o Supremo Tribunal, ${ }^{198}$ de garantia ao cidadão-eleitor, que tem o direito de haver do Estado a certeza jurídica que obsta alterações abruptas das regras inerentes à disputa eleitoral.

Conforme asseverou o Ministro Joaquim Barbosa, a discussão travada na referida ação não atacou a redação emendada para excluir a verticalização do ordenamento jurídico. Buscou-se dirimir as dúvidas sobre a eficácia das alterações promovidas via Emenda à Carta em matéria eleitoral. E, nesse sentido, acompanhou o Ministro Barbosa a posição majoritária pela qual a mudança introduzida em ano eleitoral "teria formidável impacto no respectivo resultado"199 ao interferir no equilíbrio das forças políticas e no próprio certame competitivo - um dos pilares do regime democrático.

Nessa trilha, o princípio da anterioridade eleitoral foi considerado garantia fundamental, componente, pois, do núcleo duro da Carta Maior, segundo a melhor leitura dos arts. $5^{\circ}$. $\S 2^{\circ}$. c/c $60 \S 4^{\circ}$., IV da $\mathrm{CF} / 88$ - em que pese sua prévia alteração pela EC-4/93 ${ }^{200}$. Em igual vetor, a vigência imediata colocada pela EC-52/06 em seu art. $2^{\circ}$. atentou contra a segurança jurídica (art. $5^{\circ}$., caput) e ao devido processo legal (art. $5^{\circ}$., LIV). Resultado: diante da manifestação da Suprema Corte, o Legislativo não conseguira eliminar o instituto da verticalização das eleições gerais de 2006.

\subsection{Limitação do Número de Vereadores}

Durante boa parte das décadas de oitenta e noventa o país convivia com o maligno fenômeno da inflação monetária. Inúmeros planos econômicos foram promulgados, inclusive atentando seriamente contra o ordenamento jurídico posto, visando eliminar ou amenizar as mazelas da perda do valor da moeda que assolava principalmente a classe assalariada.

Uma das principais causas do aumento em progressão geométrica da inflação é o abuso nos gastos públicos. Com o inchaço estatal promovido desde sempre, mas

e aos critérios da apuração até o momento culminante da proclamação e diplomação dos eleitos.". STF, Pleno, ADI N. 3.685, rel. Min. Ellen Gracie, 22.03.06, DJ 10.08.06.

${ }^{198}$ STF, ADI N. 3.345, rel. Min. Celso de Mello, 23.08.05, DJ 29.08.05.

${ }^{199}$ STF, Pleno, ADI N. 3.685, rel. Min. Ellen Gracie, 22.03.06, DJ 10.08.06.

${ }^{200}$ Considerou a Min. Gracie que a modificação do texto do art. 16 pela citada EC em nada alterou seu conteúdo principiológico fundamental, pois se tratou de mero aperfeiçoamento técnico visando facilitar a regulamentação do processo eleitoral. STF, Pleno, ADI N. 3.685, rel. Min. Ellen Gracie, 22.03.06, DJ 10.08.06. 
principalmente durante o governo militar, o dispêndio do governo sempre foi alvo de duras críticas e mais recentemente objeto de constante averiguação pelos Tribunais de Contas. À parte a corrupção, o esbanjamento de recursos públicos para sustento da máquina administrativa e política sempre saltou aos olhos de qualquer cidadão. Para combate a essa degradação, surgiram determinadas instituições e formulou-se complexa legislação visando restringir a discricionariedade na aplicação de verbas, bem como coibir e punir a improbidade.

Neste contexto, o Ministério Público do Estado de São Paulo ajuizou Ação Civil Pública em face da Câmara Municipal do Município de Mira Estrela, por considerar ter ocorrido desobediência a preceito constitucional, ensejando prejuízo ao erário municipal, quando da edição da Lei Orgânica N. 226 em 31 de março de 1990. A referida legislação afrontava, nos termos do parecer da promotoria, a proporcionalidade prevista no art. 29, IV, “a”, da Carta Constitucional vigente, ao fixar em onze o número de cadeiras para os Vereadores municipais a partir da legislatura iniciada em 1993, montante considerado desproporcional aos 2.651 habitantes.

Em primeira instância o pedido do Parquet foi parcialmente acolhido ${ }^{201}$, reconhecendo-se a inconstitucionalidade da lei municipal e determinando a redução do número de Vereadores para o piso constitucional (nove vagas), além de condenar à devolução dos valores que viessem a ser percebidos em desconformidade com a sentença, a partir dela. Apelaram da sentença primária o Município e a Câmara, sendo que o Tribunal de Justiça entendeu que o número estabelecido pela lei se enquadrava nos limites constitucionais do referido artigo e reformou a sentença a quo. $\mathrm{O}$ acórdão foi atacado por meio de Recurso Extraordinário, fundamentado na ofensa ao art. 29 da Constituição provocada pelo disposto no art. $6^{\circ}$., parágrafo único da Lei Orgânica de Mira Estrela.

O parecer do Subprocurador-Geral da República opinou pelo provimento do recurso, arrazoando ser a autonomia municipal vinculada ao critério da proporcionalidade estabelecido no texto da Norma Maior, propugnando pela nulidade da norma local.

${ }^{201}$ O pedido visava também a devolução de todos os subsídios indevidamente percebidos desde a publicação da assinalada lei municipal. 


\subsubsection{A nova corrente majoritária no STF}

Ao Ministro e então Presidente da Suprema Corte, Maurício Corrêa, coube a relatoria do processo e a liderança da linha majoritária que viria a prover o Recurso Extraordinário N. 197.917, de forma a fixar o número de Vereadores para os Municípios. Em seu douto entendimento, o texto constitucional destaca o princípio da proporcionalidade na definição das cadeiras municipais, dando-lhe especial tratamento, inexistente nas Cartas constitucionais anteriores.

De fato, a primeira Constituição da República deixou aos Estados a incumbência de regular sobre o modelo das Câmaras de Vereadores, no que foi seguida pela Constituição promulgada em 1934. A outorga da Carta de 1937 trouxe a eleição por sufrágio direto dos Vereadores pelos munícipes eleitores, enquanto a Constituição de 1946 empregou seus atributos democráticos para ampliar a autonomia municipal, sem, contudo, avançar sobre o tamanho da representatividade local.

Foi na Constituição de 1967 que apareceu pioneira e expressamente o princípio da proporcionalidade entre o número de Vereadores - fixado o teto de vinte e uma vagas - e o número de eleitores ${ }^{202}$. Porém, pela Emenda Constitucional N. 25, de 1985, iniciou-se a determinação de faixas, relacionando-se o número de cadeiras máximas com o tamanho da população. A reforma à Carta de 67 complementou o teto de 33 vagas para Vereadores nas localidades com mais de um milhão de habitantes. Por sua vez, a Carta de 1988, quando promulgada, estabeleceu três faixas de classificação, assim previstas:

\footnotetext{
“Art. 29. O Município reger-se-á por lei orgânica, votada em dois turnos, com interstício mínimo de dez dias, e aprovada por dois terços dos membros da Câmara Municipal, que a promulgará, atendidos os princípios estabelecidos nesta Constituição, na Constituição do respectivo Estado e os seguintes preceitos: [...]

IV - número de Vereadores proporcional à população do Município, observados os seguintes limites:

a) mínimo de nove e máximo de vinte e um nos Municípios de até um milhão de habitantes;

b) mínimo de trinta e três e máximo de quarenta e um nos Municípios de mais de um milhão e menos de cinco milhões de habitantes;

c) mínimo de quarenta e dois e máximo de cinquenta e cinco nos Municípios com mais de cinco milhões de habitantes."
}

\footnotetext{
${ }^{202}$ Art. 16, § 5o., CF/67: “Art. 16 - A autonomia municipal será assegurada: [...] § 5 - O número de Vereadores será, no máximo, de vinte e um, guardando-se proporcionalidade com o eleitorado do Município."
} 
Como se observa pela simples leitura do dispositivo, a opção pelo constituinte de efetivar a classificação por faixas deixou clara a preferência por fixar parâmetros ou limites, legando aos Municípios a tarefa de determinar o número exato de Vereadores, de acordo com as características locais. Não fosse assim, poderia ter nitidamente estabelecido uma fórmula que marcasse a quantia exata de cadeiras a cada Município. Além do mais, o disposto no inciso IV encontra-se inserido em artigo que trata da autonomia municipal e descreve a competência legislativa do ente municipal. Veja-se que, nos incisos I, II e III do citado artigo, situam-se as regras constitucionais para as eleições do Executivo e Legislativo ${ }^{203}$. Nos incisos V e VI, encontra-se a limitação dos subsídios de ambos os Poderes. Interessante notar que também o subsídio dos Vereadores deverá ser fixado de acordo com critérios estabelecidos pelas próprias Câmaras Municipais, observado os limites máximos e mínimos impostos pelo texto constitucional. Esses balizamentos foram acrescidos pelas Emendas Constitucionais N. 1/1992 e N. 25/2000 em seis faixas de classificação, proporcionalmente à população e com parâmetros fixados em função do subsídio dos Deputados Estaduais. Nos incisos seguintes do mesmo artigo, o texto segue dispondo sobre a matéria passível de regulação pela Lei Orgânica Municipal. Deve-se atentar ao inciso VII, que limita o total da despesa com a remuneração dos Vereadores a 5\% da receita do Município. Sem dúvida houve preocupação do constituinte com os gastos públicos derivados da folha municipal, o que de certo modo, enfraqueceria o argumento do excessivo dispêndio de verbas com eventual número exacerbado de cadeiras na Câmara, motivação da ação civil pública proposta pelo Ministério Público do Estado de São Paulo.

Apesar da análise sistemática do art. $29 \mathrm{CF} / 88$ trazer as conclusões supra expostas, como apontou o Ministro Corrêa no recurso em exame, desde a promulgação da atual Carta, duas correntes se formaram quanto à interpretação do artigo constitucional que rege o número de Vereadores por Município. A primeira corrente extrai do texto citado a autonomia da Câmara para fixar o seu número, dentro dos tetos e pisos estabelecidos pela Norma Magna. A outra - à qual se filia o Ministro relator - sugere que o princípio da proporcionalidade indica a exigência de cálculos e critérios aritméticos a serem efetuados entre o tamanho da população e o número de representantes municipais.

\footnotetext{
${ }^{203}$ Relativamente às competências constitucionalmente fixadas, v. FERNANDA DIAS MENEZES DE ALMEIDA,
} Competências na Constituição de 1988, 2ª ed., São Paulo, Atlas, 2000. 
Fato é que, em julgado de 1996, a Corte decidira em prol da autonomia do Município, na esteira do pensamento da primeira corrente, e que assim restou ementado:

"CONSTITUCIONAL.VEREADORES: FIXAÇÃO DO SEU NÚMERO. CF, art. 29, IV.

I - O Supremo Tribunal Federal suspendeu a eficácia do $\S 1^{\circ}$., incisos I a XVI, e do $\S$ $2^{\circ}$., do art. 61 da Constituição do Estado do Tocantins, que fixava o número de Vereadores dos Municípios do Estado. Entendeu o Supremo Tribunal Federal que a competência para a fixação do número de Vereadores é do Município, observados os limites estabelecidos na Constituição Federal, art. 29, IV." 204

A prevalência da autonomia municipal na sua auto-organização foi a base da corrente majoritária nos julgados observados na década de 90, tendo sido reconhecida em algumas oportunidades pela Corte Eleitoral Superior, quando se assentou que não há de se falar em critério aritmético para fixar o exato número de cadeiras no Legislativo municipal. Assim decidiu o TSE:

"CÂMARA MUNICIPAL: NÚMERO DE VEREADORES: AUTONOMIA DA LEI ORGÂNICA DE CADA MUNICÍPIO.

A Constituição Federal reservou à autonomia de cada Município a fixação do número dos seus Vereadores, desde que contida entre o limite mínimo e o limite máximo correspondentes à faixa populacional respectiva. Se da própria Constituição não é possível extrair outro critério aritmético de que resultasse a predeterminação de um número certo de Vereadores para cada Município, não há no sistema constitucional vigente, instância legislativa ou judiciária que a possa ocupar." 205

Os precedentes mostram inclusive que o princípio da proporcionalidade

foi diretamente enfrentado nas decisões do TSE e considerado juris tantum, mitigado "pela opção política dos Municípios de fixarem as cadeiras na Câmara de Vereadores, observadas as balizas constitucionais indicadoras de números mínimo e máximo."206

Não obstante, o Ministro Maurício Corrêa ressaltou que, quando do exercício do cargo de Ministro do TSE, não teve oportunidade de manifestar-se a respeito da questão. ${ }^{207}$ Tendo então a chance de analisar a matéria, na qualidade de relator do acórdão em exame, considerou estar superada a jurisprudência até então formada ${ }^{208} \mathrm{e}$ optou por aderir à corrente que busca maximizar a proporcionalidade de modo aritmético, entendendo que, do texto constitucional é possível extrair-se a exigência da estrita razão matemática a determinar o número exato de vagas que cabe ao Município.

\footnotetext{
${ }^{204}$ STF, Pleno, AGRRCL 488-TO, rel. Min. Carlos Velloso, DJ 06.12.96.

${ }^{205}$ STF, RMS N. 1.945, rel. Min. Sepúlveda Pertence, DJ 11.06.93.

${ }^{206}$ STF, RMS N. 1.949, rel. Min. Marco Aurélio, DJ 17.08.93.

${ }^{207}$ STF, Pleno, RE N. 197.917, rel. Min. Maurício Corrêa, 06.06.02, DJ 07.05.04.

${ }^{208}$ STF, Pleno, RE N. 197.917, rel. Min. Maurício Corrêa, 06.06.02, DJ 07.05.04.
} 
Este se tornou o novo pensamento majoritário formado no STF, uma vez que a maioria dos Ministros seguiu o voto do relator ${ }^{209}$, cujo posicionamento, de acordo com suas próprias palavras, advém da exegese que realiza sobre o termo "proporcionalidade", constante do inciso IV do art. 29 da CF/88: "número de Vereadores proporcional à população do Município". Considerou o Ministro relator que a livre fixação pelo legislador municipal do número de vagas na Câmara Municipal, ainda que feita dentro dos limites constitucionalmente estabelecidos, é arbitrária e subjetiva. Fundamentou sua posição analisando a intenção do constituinte (a partir de pareceres da comissão de sistematização) e com os critérios adotados por este para fixar o número de Deputados Federais e Estaduais - expressos respectivamente nos artigos 45, § $1^{\circ}$. e 27, CF/88 $8^{210}$.

O empirismo também foi empregado para justificar a mudança da jurisprudência da Corte Suprema. De acordo com informações trazidas aos votos, diversos Municípios paulistas possuíam "exagerado número de Vereadores, em flagrante desrespeito aos critérios de proporcionalidade previstos na Constituição" ${ }^{, 211}$. O quadro abaixo retrata a situação na qual Municípios de diminuta população possuem tantos Vereadores quanto aqueles mais populosos, embora respeitem os limites dados pela Constituição.

\footnotetext{
${ }^{209}$ Votaram também pela procedência do recurso os Min. Gilmar Mendes, Nelson Jobim, Joaquim Barbosa, Carlos Britto, Cezar Peluso, Carlos Velloso e Ellen Gracie. STF, Pleno, RE N. 197.917, rel. Min. Maurício Corrêa, 06.06.02, DJ 07.05.04.

${ }^{210}$ Note-se que o número de Deputados Federais é determinado proporcionalmente à população, dentre os limites de oito a setenta vagas parlamentares por unidade da Federação. O número de Deputados Estaduais a figurar nas respectivas assembléias é o triplo da representação estadual na Câmara dos Deputados.

${ }^{211}$ STF, Pleno, RE N. 197.917, rel. Min. Maurício Corrêa, 06.06.02, DJ 07.05.04.
} 
Quadro 1: "Relação Número de Vereadores x População" 212

\begin{tabular}{|c|c|c|}
\hline Município & População (IBGE-2003) & $\begin{array}{l}\text { Número de Vereadores } \\
\text { (legislatura 2001-2004) }\end{array}$ \\
\hline Bertioga & 17.002 & 09 \\
\hline Adamantina & 32.766 & 09 \\
\hline Pilar do Sul & 23.165 & 09 \\
\hline Santa Branca & 20.097 & 09 \\
\hline Hortolândia & 115.720 & 11 \\
\hline São Miguel Arcanjo & 27.508 & 11 \\
\hline Ubatuba & 55.033 & 13 \\
\hline Jacareí & 167.751 & 13 \\
\hline Sumaré & 168.058 & 13 \\
\hline Ribeirão Pires & 97.550 & 15 \\
\hline Itaquaquecetuba & 228.344 & 19 \\
\hline Guarulhos & 972.197 & 21 \\
\hline Balbinos & 1.388 & 11 \\
\hline Jardinópolis & 24.615 & 17 \\
\hline Cafelândia & 15.331 & 15 \\
\hline Mira Estrela & 2.636 & 11 \\
\hline Itapeva & 77.767 & 19 \\
\hline Taquarituba & 19.997 & 15 \\
\hline Garça & 40.481 & 17 \\
\hline Cubatão & 97.257 & 20 \\
\hline São Manuel & 38.271 & 21 \\
\hline Pereira Barreto & 25.359 & 17 \\
\hline
\end{tabular}

A "desproporcionalidade" se observa, segundo a corrente do cálculo aritmético, ao comparar-se um Município como o de São Manuel, com vinte e um Vereadores, em face de Guarulhos, cuja população é mais que vinte e cinco vezes maior, porém abriga a mesma quantia de vagas na Câmara. Ou então de Taquarituba, que com vinte mil habitantes tem quatro Vereadores a mais que Hortolândia, com população quase seis vezes maior. Em hipótese, o menor Município paulista - na atualidade Borá, com menos de mil habitantes - poderia ter vinte e um Vereadores, em face de qualquer Município de mais de novecentos mil habitantes, que poderia ter apenas nove. Ou ainda que este possuísse igualmente vinte e uma cadeiras na Câmara, a razão proporcional estaria invertida.

Para a nova corrente majoritária, adepta do cálculo aritmético da proporcionalidade, ao verificar a realidade dos Municípios, mostra-se que o princípio da razoabilidade encontra-se igualmente deturpado, bem como não resta preservada a

${ }^{212}$ Fonte: STF, Pleno, RE N. 197.917, rel. Min. Maurício Corrêa, 06.06.02, DJ 07.05.04. 
isonomia entre os entes municipais. Na visão do Ministro Corrêa, a edição de leis em desrespeito à razoabilidade configura excesso do poder de legislar e desvirtua a verdadeira ratio do legislador, segundo a qual a representação deverá ser diretamente proporcional ao tamanho da população.

A proposta constante na PEC N. 82/91, de relatoria do então Deputado Nelson Jobim, pedia a aplicação de "regra de três", que, de certo modo, foi adotada pelo relator, na construção do que denominou de "fórmula ideal", aplicando a razão matemática entre as faixas para se chegar as seguintes conclusões:

a) Dividindo-se o teto da primeira faixa (1.000.000 de habitantes pelo limite máximo - 21 vagas), chega-se ao quociente de um Vereador para cada 47.619 munícipes;

b) Fixando-se a regra que os Municípios até 47.619 habitantes terão nove Vereadores, estabelecem-se novas faixas, acrescendo um novo posto à vereança a cada 47.619 habitantes;

c) Realizando-se a mesma operação aritmética para as duas faixas restantes, constrói-se o quadro abaixo: 
Quadro 2 : "População x Número de Vereadores no novo critério"213

\begin{tabular}{|c|c|}
\hline Número de habitantes do Município & N. de Vereadores \\
\hline 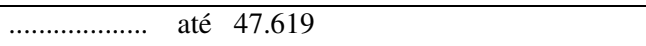 & 09 (nove) \\
\hline De 47.620 até 95.238 & $10(\mathrm{dez})$ \\
\hline De 95.239 até 142.857 & 11 (onze) \\
\hline De 142.858 até 190.476 & $12($ doze $)$ \\
\hline De 190.477 até 238.095 & 13 (treze) \\
\hline De 238.096 até 285.714 & 14 (catorze) \\
\hline De 285.715 até 333.333 & 15 (quinze) \\
\hline De 333.334 até 380.952 & 16 (dezesseis) \\
\hline De 380.953 até 428.571 & 17 (dezessete) \\
\hline De 428.572 até 476.190 & 18 (dezoito) \\
\hline De 476.191 até 523.809 & 19 (dezenove) \\
\hline De 523.810 até 571.428 & 20 (vinte) \\
\hline De 571.429 até 1.000 .000 & 21 (vinte e um) \\
\hline De 1.000 .001 até 1.121 .952 & 33 (trinta e três) \\
\hline De 1.121 .953 até 1.243 .903 & 34 (trinta e quatro) \\
\hline De 1.243 .904 até 1.365 .854 & 35 (trinta e cinco) \\
\hline De 1.365 .855 até 1.487 .805 & 36 (trinta e seis) \\
\hline De 1.487 .806 até 1.609 .756 & 37 (trinta e sete) \\
\hline De 1.609 .757 até 1.731 .707 & 38 (trinta e oito) \\
\hline De 1.731 .708 até 1.853 .658 & 39 (trinta e nove) \\
\hline De 1.853 .659 até 1.975 .609 & 40 (quarenta) \\
\hline De 1.975 .610 até 4.999 .999 & 41 (quarenta e um) \\
\hline De 5.000 .000 até 5.119 .047 & 42 (quarenta e dois) \\
\hline De 5.119 .048 até 5.238 .094 & 43 (quarenta e três) \\
\hline $\begin{array}{llll}\text { De } & 5.238 .095 & \text { até } 5.357 .141\end{array}$ & 44 (quarenta e quatro) \\
\hline De 5.357 .142 até 5.476 .188 & 45 (quarenta e cinco) \\
\hline De 5.476.189 até 5.595 .235 & 46 (quarenta e seis) \\
\hline De 5.595 .236 até 5.714 .282 & 47 (quarenta e sete) \\
\hline De 5.714 .283 até 5.833 .329 & 48 (quarenta e oito) \\
\hline De 5.833 .330 até 5.952 .376 & 49 (quarenta e nove) \\
\hline De 5.952.377 até 6.071 .423 & 50 (cinquenta) \\
\hline $\begin{array}{lll}\text { De } & 6.071 .424 & \text { até } 6.190 .470\end{array}$ & 51 (cinquenta e um) \\
\hline De 6.190 .471 até 6.309 .517 & 52 (cinquenta e dois) \\
\hline De 6.309 .518 até 6.428 .564 & 53 (cinquenta e três) \\
\hline $\begin{array}{lll}\text { De } & 6.428 .565 & \text { até } 6.547 .611\end{array}$ & 54 (cinquenta e quatro) \\
\hline Acima de ................ 6.547 .611 & 55 (cinquenta e cinco) \\
\hline
\end{tabular}

${ }^{213}$ Fonte: STF, Pleno, RE N. 197.917, rel. Min. Maurício Corrêa, 06.06.02, DJ 07.05.04. 
O intrínseco cálculo elimina toda e qualquer margem política discricionária. Porém, para o Ministro relator, constitui-se o método que ilustra a correta interpretação do dispositivo constitucional e atende aos princípios constitucionais da moralidade, impessoalidade, economicidade e da proporcionalidade da representação política.

A nova corrente majoritária afastou a hipótese de ofensa à autonomia municipal (contida nos arts. $1^{\circ}$., 18, 29,CF/88), pois ponderou ser mais relevante o princípio da proporcionalidade expresso no texto constitucional. Assim votaram, além do relator, os Ministros Gilmar Mendes, Nelson Jobim e Cezar Peluso. Os demais Ministros que aderiram à corrente majoritária que se formou, apenas se limitaram a seguir o voto do relator, provendo o recurso, dando assim razão ao juízo de primeiro grau que considerou inconstitucional, via controle incidental, a legislação municipal, sem, contudo fixar de pronto o novo número de Vereadores. Correta a decisão na opinião do Ministro Corrêa, pois do contrário, eventual imposição em sentença do exato número de Vereadores configurar-se-ia real usurpação das funções do Legislativo municipal e atuação do Judiciário como legislador positivo. À Câmara Municipal de Mira Estrela caberia adequar sua legislação. Porém, seriam aplicáveis para a legislatura então vigente os efeitos da decisão?

Em que pese a sentença de primeiro grau ter se referido a legislatura de 1993 a 1997, a decisão do Supremo veio a ser prolatada durante o quadriênio iniciado em 2001, de modo que, somente após a publicação desta, em 07 de maio de 2004, poderia se cogitar da adequação ao novo entendimento jurisprudencial. Ademais, a decisão proferida em sede de controle incidental e concreto, projetaria seus efeitos erga omnes, atingindo, todos outros Municípios do país, em pleno ano eleitoral e durante o último ano da legislatura municipal.

Ao contrário do que propôs o Ministro relator, para o Ministro Gilmar Mendes, a declaração de inconstitucionalidade não poderia afetar a legislatura em curso. Não teria a decisão eficácia ex tunc, no seu juízo prudencial, uma vez que "os atos praticados com base na lei inconstitucional que não mais se afigurem suscetíveis de revisão não são afetados pela declaração de inconstitucionalidade."214 Impossíveis de se tornarem

${ }^{214}$ STF, Pleno, RE N. 197.917, rel. Min. Maurício Corrêa, 06.06.02, DJ 07.05.04. Cf. voto do Min. Gilmar Mendes, para quem, de acordo com parte da doutrina, "a lei inconstitucional não poderia ser considerada nula, porque, tendo sido editada regularmente, gozaria de presunção de constitucionalidade, (...). A lei inconstitucional não seria, portanto, nula ipso jure, mas apenas anulável. V. também STF, RE 79.343, rel. 
nulos seriam os mandatos exercidos pelos Vereadores nas legislaturas anteriores à decisão por sua própria natureza e pelo prejuízo que causaria a nulidade de todos os atos legislativos até então praticados. Entendeu o Ministro estar prestigiando a segurança jurídica, assim se pronunciando:

"No caso em tela, observa-se que eventual declaração de inconstitucionalidade com efeito ex tunc ocasionaria repercussões em todo o sistema vigente, atingindo decisões que foram tomadas em momento anterior ao pleito que resultou na atual composição da Câmara Municipal: fixação do número de Vereadores, fixação do número de candidatos, definição do quociente eleitoral. Igualmente, as decisões tomadas posteriormente ao pleito também seriam atingidas, tal como a validade da deliberação da Câmara Municipal nos diversos projetos e leis aprovados." 215

\subsubsection{A corrente divergente}

O Ministro Sepúlveda Pertence foi o primeiro dos julgadores a alertar para a mudança que se formava no entendimento das Cortes Suprema e Eleitoral, recordando a decisão do TSE no RMS N. 1.945, anteriormente mencionada. No mesmo sentido do julgado, o Tribunal Eleitoral havia editado, em 1992, a Resolução N. 18.083 do TSE em resposta à Consulta N. 12.437/ $\mathrm{PB}^{216}$, que, em suma, assentou não haver determinação na Constituição que cedesse espaço a qualquer aplicação de cálculo aritmético. É bem verdade que o mencionado Mandado de Segurança reformara decisão do Colendo Tribunal Regional Eleitoral do Rio Grande do Sul, cujo entendimento, já nos anos noventa, relacionava a proporcionalidade do art. $29 \mathrm{CF} / 88$ com a necessidade de cálculo matemático exato a extrair um número certo e predeterminado de Vereadores.

Min. Leitão de Abreu, RTJ n. 82, p.791-5. G. F. MENDES, Jurisdição Constitucional, São Paulo, Saraiva, 1999, p. 271.

${ }^{215}$ STF, Pleno, RE N. 197.917, rel. Min. Maurício Corrêa, 06.06.02, DJ 07.05.04.

${ }^{216}$ A Consulta N. 12.437 - TRE/PB colocava as seguintes questões para resposta em tese da Corte: "a) Na hipótese de omissão de Lei Orgânica Municipal quanto à fixação de número de vagas à Câmara respectiva, como deverá proceder a Justiça Eleitoral com relação ao registro de candidatos, tendo em vista o disposto no art. 92, b, do Código Eleitoral c.c. o art. 11 da Lei N. 8.214/91? b) Diante dessa situação, poderá o juiz eleitoral tomar por base, quando do registro, o número de vagas estabelecido na eleição municipal imediatamente anterior?" V. TSE, Res. N. 18.083, rel. Min. Sepúlveda Pertence, 28.04.92, DJ 06.05.92.

A decisão foi sintetizada da seguinte maneira: Ementa: Fixação do número de Vereadores a eleger em cada Município nas eleições de 1992. 1. O número de Vereadores a eleger, nas próximas eleições, em cada Município, é o fixado na respectiva Lei Orgânica ou, na omissão dessa, o fixado pela Justiça Eleitoral, para as últimas eleições. 2. No Município novo, a fixação do número da composição inicial da Câmara dos Vereadores será feita por lei do Município do qual se haja desmembrado; não publicada a lei até 23.6.92, prevalecerá o número mínimo da faixa populacional correspondente (Constituição, art. 29, IV). 3. Em qualquer caso, se a fixação legal ultrapassar o máximo admitido pela Constituição para a respectiva faixa (art. 29, IV), o juiz deverá comunicá-lo à Câmara competente para que o reduza; se não se produzir a redução por lei, até 23.6.92, prevalecerá o máximo permitido pela Constituição, do qual o juiz dará ciência pública. 
O principal argumento do Ministro Pertence relembra a necessidade de ater-se ao texto legal quando do exercício da atividade exegética pelo aplicador da lei. Como bem frisou o Ministro dissidente, "se pretendesse a Constituição determinar um critério aritmético rígido, do qual decorresse a determinação precisa do número de Vereadores de cada Município, (...)" o faria de forma clara e precisa, pois "o constitucionalismo brasileiro conhece fórmula simples e inequívoca de expressão normativa". Referia-se o Ministro à Carta de $1934^{217}$ que fixava uma fórmula de proporcionalidade "de clareza meridiana", nos termos do eminente Ministro ${ }^{218}$. Disso deflui que não se deve presumir o que o constituinte de 88 deveria ou pretendia ter aprovado, mas por diversos motivos não o fez. Nada autoriza, como quis o Ministro Jobim, ao trazer à colação os pareceres da Comissão de Sistematização, julgar-se conforme matéria que deveria ter sido aprovada no lugar do que restou positivado no texto constitucional.

Além do mais, conforme propugnou o Ministro Marco Aurélio, nenhuma das Emendas Constitucionais até então editadas (na data do julgado montavam a mais de quarenta) buscou adentrar a matéria e fixar a proporcionalidade com exatidão. Quis com a assertiva demonstrar que a opção política fica a cargo do Legislativo. Para confirmar sua posição, fez referência ao art., 45 da $\mathrm{CF} / 88$, que remete à lei complementar a competência de determinar o número total de parlamentares na Câmara Federal. Atentando à harmonia dos Poderes, atacou: "Não me consta, data vênia, que um acórdão do Supremo Tribunal Federal possa fazer as vezes de lei complementar".

Em combate ao forte argumento do Ministro Jobim, para quem a interpretação contrária ao cálculo aritmético, ao ser aplicada ao art. $45 \mathrm{CF} / 88$, levaria à possibilidade de todos Estados possuírem setenta vagas para Deputado Federal (teto colocado pela Constituição), respondeu o Ministro Marco Aurélio que essa seria uma opção política deixada ao legislador. Este poderia sim, fixar no limite máximo o número de

217 Art. 23, § $1^{\circ}$., CF/34: "O número dos Deputados será fixado por lei: os do povo, proporcionalmente à população de cada Estado e do Distrito Federal, não podendo exceder de um por 150 mil habitantes até o máximo de vinte, e deste limite para cima, de um por 250 mil habitantes; os das profissões, em total equivalente a um quinto da representação popular. Os Territórios elegerão dois Deputados." O texto veio a ser praticamente repetido no art. 58 da Constituição de 1946 e no art. 41 da Carta de 1967. Esta última apenas alterou o limite de 150 mil para 300 mil habitantes e de vinte para vinte e cinco Deputados, limite para além do qual levaria a proporção para um a cada milhão de habitantes. Somente com a EC-22/82 é que se adotou uma fórmula aberta e flexível de proporcionalidade, estabelecendo somente piso e teto, sem fixar números exatos de vagas no Legislativo.

218 STF, Pleno, RE N. 197.917, rel. Min. Maurício Corrêa, 06.06.02, DJ 07.05.04. Cf. voto do Min. Sepúlveda Pertence. 
Deputados, sem incorrer em inconstitucionalidade da lei complementar. O sólido contraargumento do Ministro Marco Aurélio se resume em suas palavras:

"Digo que não será merecedora da pecha de inconstitucional uma lei complementar que observe, numa opção político-legislativa - o que não podemos fazer no julgamento de um recurso extraordinário -, esse piso e teto de oito e setenta e disponha a respeito, sem chegar-se a uma proporcionalidade absoluta, matemática, que nem Vossa Excelência, no voto preconizado, chega." 219

\subsubsection{Distorção da representação política}

Outro ponto, de caráter estritamente matemático - e que talvez por essa natureza não tenha sido alvo de debate, apesar de levemente apontado pelo Ministro Pertence - consiste no fato de que a fórmula proposta pelo Ministro Corrêa, criando faixas com intervalos menores do que os previstos no art. $29 \mathrm{CF} / 88$, em prestígio à dita proporcionalidade, gera distorções na representação política dos Municípios, pois, de acordo com o critério que assume, tem-se que: para um Município com 2.651 habitantes, como é o caso de Mira Estrela, fixados nove Deputados, a relação de proporcionalidade indicaria haver um Deputado para cada 295 habitantes. Por sua vez, um Município como Ubatuba, com 55.033 habitantes à época do julgado, teria um Deputado para cada 5.503 habitantes, ou seja, uma representatividade política proporcionalmente dezoito vezes inferior à de Mira Estrela; já o Município de Guarulhos, com 972 mil habitantes seria representado na proporção de um Vereador para cada grupo de 46.286 habitantes, oito vezes inferior a Ubatuba e cento e cinquenta e sete vezes "menos representado" - se assim se pudesse dizer - do que Mira Estrela. De modo que, a tão almejada proporcionalidade pela corrente majoritária restou desatendida, mormente ao se pinçarem as localidades menos habitadas: certamente, Borá terá um por cento de sua população na Câmara de Vereadores, local onde as chances para se concorrer ao pleito eleitoral são maiores que a do Município vizinho de Garça que terá proporção de um Vereador para cada 4.500 habitantes. É certo que não se pretende que as capitais guardem a mesma proporção dos Municípios menores. Para tanto, as constituições pretéritas estabeleceram tetos. É cristalino também que tal "desproporção" enseja desequilíbrio nos gastos do ente federativo, dado que a arrecadação municipal varia também em função do porte do Município, ou seja: Borá e Mira Estrela certamente gozam de piores condições

${ }^{219}$ STF, Pleno, RE N. 197.917, rel. Min. Maurício Corrêa, 06.06.02, DJ 07.05.04. 
orçamentárias para arcar com nove vagas de vereança do que Ubatuba com dez e Guarulhos com vinte e uma.

Em suma, há vários elementos políticos a serem relevados e, ao se adicionar o elemento da representação política, não há como retirar a razão dos Ministros divergentes, principalmente do Ministro Pertence, pois hialina a oportunidade do constituinte repetir - e não o fez - os textos das Cartas pretéritas que continham fórmula matemática de representação: um Deputado para tantos habitantes.

\subsubsection{Abalo à autonomia municipal}

A autonomia municipal, na definição de Hely LOPES MeIRELles é “prerrogativa política outorgada pela Constituição a entidades estatais internas (Estadosmembros, Distrito Federal e Municípios), para compor seu governo e prover sua Administração Segundo o ordenamento jurídico vigente." ${ }^{220}$ Como ensina o saudoso mestre, a Lei Maior cuidou de enumerar alguns princípios asseguradores dessa autonomia: o poder de auto-organização (elaboração de Lei Orgânica própria); poder de autogoverno; poder normativo próprio ou de autolegislação e; poder de auto-administração.

A relevância do princípio da autonomia municipal está estampada no status constitucional que lhe foi conferido. Isso é reforçado pelo ensinamento do autor, segundo o qual "a Constituição de 1988, ampliando a autonomia municipal e incluindo o Município como peça essencial da Federação, deu-lhe poder de editar sua própria lei orgânica, (...), equivalente à Constituição Municipal.”, 221

Como relembrou o Ministro Pertence no julgamento do citado Recurso Extraordinário, "não há no sistema constitucional vigente instância legislativa ou judiciária competente para fixar critérios outros que restringissem a autonomia municipal, salvo a da própria Lei Orgânica de cada Município.” ${ }^{222}$ Compartilhando desse entendimento, o Ministro Celso de Mello reforçou a prevalência da autodeterminação municipal face o princípio da proporcionalidade, assim se pronunciando:

\footnotetext{
${ }^{220}$ Cf. art. 18, CF/88 e H. L. MeIRELlES, Direito Municipal Brasileiro, 15ª . ed., São Paulo, Malheiros, 2006, p. 90 .

${ }^{221}$ H. L. MeIRELlES, Direito Municipal Brasileiro, cit., p. 91-94. Como ainda adverte H. L. MEIRELLES, não se trata de um "poder de autogoverno decorrente da Soberania Nacional, mas como um direito publico subjetivo de organizar seu governo e prover sua Administração, nos limites que a Lei Maior lhes traça."

222 H. L. MEIRELLES, Direito Municipal Brasileiro, cit, p. 457.
} 
"Entendo, Senhor Presidente, que a controvérsia ora em exame há de ser resolvida em face do princípio da autonomia municipal, que representa, no contexto de nossa organização político-jurídica, uma das pedras angulares sobre a qual se estrutura o edifício institucional da Federação brasileira." 223 (grifos no original)

E, em consonância com H. L. MeIRELles, o Ministro Celso de Mello pontuou que:

“Cabe assinalar, neste ponto, que a autonomia municipal erige-se à condição de princípio estruturante da organização institucional do Estado brasileiro, qualificando-se como prerrogativa política, que, outorgada ao Município pela própria Constituição da República, somente por esta pode ser validamente limitada." 224 (grifos no original)

A Carta de 1988 é esplendorosa em princípios democráticos se comparada com sua antecessora. A cessão de maior autonomia aos entes municipais é uma de suas marcas democráticas. Legar ao Município o poder de auto-organização, isto é, a possibilidade de determinar sua organização, nesse caso legislativa, considerando as peculiaridades do local, bem como as necessidades que representação, foram tópicos que o constituinte, no espírito democrático que avançava, julgou serem melhor decididos por aqueles que conhecem a realidade local: os próprios Municípios. Até a Carta Magna vigente, a organização municipal era tema afeto à regulamentação estadual. Se nem a União nem os Estados foram considerados pelo constituinte de 88 entes aptos a determinar a organização dos Municípios, o que se dirá da ingerência das Cortes Judiciárias.

À época do julgamento do RE N. 197.917, pendia em exame pelo Plenário do Supremo a ADI N. 692-4 ${ }^{225}$. O julgamento desta Ação Declaratória se perfez em 02 de agosto de 2004. Sua ementa reafirma o valor constitucional supremo da autonomia municipal:

"EMENTA: LEI ESTADUAL QUE ESTABELECE NÚMERO DE VEREADORES. AUTONOMIA MUNICIPAL. INCONSTITUCIONALIDADE. PRECEDENTES.

1. Arguição de inconstitucionalidade do $\S 1^{\circ}$, I a X, e do $\S 2^{\circ}$, todos do art. 67 da Constituição do Estado de Goiás.

2.Viola a autonomia dos Municípios (art. 29, IV, da CF/1988) lei estadual que fixa número de Vereadores ou a forma como essa fixação deve ser feita.

3.Ação direta julgada precedente." 226

Não fosse o curto intervalo de tempo entre as duas decisões - RE N. 197.917 e ADI N. 692, poderia se arriscar que a Corte mudara novamente seu

${ }^{223}$ H. L. MeIrelles, Direito Municipal Brasileiro, cit, p. 500.

${ }^{224}$ H. L. MeIRELLES, Direito Municipal Brasileiro, cit., p. 501.

${ }^{225}$ Em junho de 1992 o relator da ADI N. 692-4, o Ministro Moreira Alves havia suspendido liminarmente os preceitos da Constituição Estadual de Goiás que fixava o número de Vereadores para os Municípios do Estado. STF, Pleno, ADI N. 692-4/GO, rel. Min. Joaquim Barbosa, 02.08.04, DJ 01.10.04.

${ }^{226}$ STF, Pleno, ADI N. 692-4/GO, rel. Min. Joaquim Barbosa, 02.08.04, DJ 01.10.04. 
posicionamento. Todavia, nada se pode concluir senão que as decisões caminharam em sentidos opostos e forneceram conclusões diversas, gerando mais confusão em torno do tema.

Em acréscimo, ao observarmos a ementa de julgado do STF datado de 1994 sobre o mesmo tema - ADI-MC N. 1.038-7 - nota-se a semelhança das decisões. Ambas declararam a inconstitucionalidade das Constituições Estaduais que buscaram fixar o número de Vereadores:

"EMENTA: CONSTITUCIONAL. VEREADORES: FIXAÇÃO DO SEU NÚMERO. Constituição do Tocantins, art. $61, \S 1^{\circ}$, incisos I a XVI, $\S 2^{\circ}$. Constituição Federal, art. 29, IV.

I - Compete ao Município fixar o número de Vereadores, que será proporcional à população e observados os limites estabelecidos na Constituição Federal. C.F., art. 29, IV.

II - Suspensão liminar do $\S 1^{\circ}$, incisos I a XVI, e do $§ 2^{\circ}$, do art. 61 da Constituição do Estado do Tocantins.

III - Cautelar deferida." 227

Em suma, as decisões em sede de Ação Declaratória de Inconstitucionalidade - a última prolatada pelo Supremo dez anos após a primeira, porém poucos meses após o julgamento do indicado RE N. 197.917 - enalteceram a autonomia municipal, ao contrário do assinalado acórdão que redefiniu as regras para as Câmaras Municipais.

Ao mostrar expressamente, no julgamento das mencionadas ADI, que ao Município - e não ao Estado - compete fixar o número de Vereadores, citando, inclusive o art. 29 da Constituição Federal, não restam óbices para se afirmar que a própria Corte Suprema, no julgamento da constitucionalidade da Lei Orgânica de Mira Estrela, atuou contrariando sua competência, seus próprios princípios e decisões: fixou o número de Vereadores para cada ente municipal. Pisou o Supremo em terreno de opção políticolegislativa, como bem advertira várias vezes o Ministro Marco Aurélio em seu voto divergente, no Recurso Extraordinário em exame:

"Quero dizer que a fixação do número de Vereadores faz-se, desde que respeitado o piso e o máximo constitucionais, a partir de uma opção político-legislativa do próprio Município, não havendo campo para atuar-se nessa mesma fixação, inserindo, no cenário nacional, um acórdão do Supremo Tribunal Federal com contornos, com conteúdo, de verdadeira lei complementar." 228

\footnotetext{
${ }^{227}$ STF, Pleno, ADI-MC N. 1.038/TO, rel. Min. Carlos Velloso, 25.03.94, DJ 06.05.94.

${ }^{228}$ STF, Pleno, RE N. 197.917, rel. Min. Maurício Corrêa, 06.06.02, DJ 07.05.04. Cf. voto do Min. Marco Aurélio.
} 
A observação reveste-se de especial pertinência, pois a autorização cedida ao poder municipal de realizar um juízo político foi opção do legislador constituinte, de modo que a intromissão do Supremo nessas cercanias fere não só a autonomia municipal como arranha o equilíbrio de Poderes, uma vez que a Carta Maior não lhe conferiu competência para atuar no campo político. Tanto assim foi, que o Ministro Pertence constatou peremptoriamente que:

\footnotetext{
"Por outro lado, Senhor Presidente, os trabalhos da Assembléia Nacional Constituinte confirmam que, então, efetivamente, se decidiu politicamente pela reserva da matéria à autonomia de organização dos Municípios, com as únicas restrições de que se contivesse cada qual nos limites das respectivas faixas populacionais." 229
}

Todo esse posicionamento vem amplamente reforçado pela doutrina.

Assim é que H. L. Meirelles, com apoio em F.C. Pontes de Miranda, Sampaio DóRia e outros publicistas pátrios e estrangeiros e empregando as palavras de MEIRELLES TEIXEIRA, afirma que "os princípios constitucionais garantidores de sua autonomia (arts. 29-30), constituem um verdadeiro direito público subjetivo, oponível ao próprio Estado (União), sendo inconstitucionais as leis que, de qualquer modo, o atingirem em sua essência". E, em seguida, adiciona: "O governo local é que provê a Administração em tudo quanto respeite ao interesse local do Município, repelindo, por inconstitucional, qualquer intromissão de outro órgão, autoridade ou poder." 230

A autonomia municipal não foi admitida como uma total liberalidade a se conceder aos Municípios na questão do dimensionamento das Câmaras Municipais. O constituinte gravou com restrições a decisão autônoma de cada ente, impondo limites máximos ao número de cadeiras no Legislativo municipal, com correspondência ao tamanho da população, de acordo com faixas de classificação.

Porém, essa mitigação parece não ter sido suficiente. É fato que vem se presenciando no país uma degradação da classe política que afunda o Legislativo em uma crise sem fim. A sociedade se cansa de observar (apaticamente, por vezes) a prioridade dada pelos parlamentares e demais detentores de cargos políticos a assuntos que os beneficiam. Estes se esmeram em aprovar - com urgência - o aumento de suas próprias remunerações, expandir gastos com suas estruturas, gerar mais benefícios a si mesmos.

Não só o povo, mas também os Ministros do Supremo ficam pasmos com tanto descaso com a coisa pública pelos próprios agentes públicos. Todavia, o que se quer

${ }^{229}$ STF, Pleno, RE N. 197.917, rel. Min. Maurício Corrêa, 06.06.02, DJ 07.05.04.

${ }^{230}$ H. L. MEIRELLES, Direito Municipal Brasileiro, cit., p. 91-92. 
apontar no presente estudo é a forma com que o Judiciário vem agindo nos últimos anos visando suprir a lacuna deixada pelo Legislativo ou impedir que esse legisle em causa própria. Novamente depara-se com o afã do Judiciário que, na tentativa de moralização ou de maior efetividade da lei, invade competências de outros Poderes, julga politicamente, conduta característica de um típico ativismo judicial. Tema que será explorado no capítulo seguinte sobre a fidelidade partidária.

\subsubsection{A Resolução N. 21.702 do TSE}

Após amplo debate sobre a modulação dos efeitos da declaração de Inconstitucionalidade, capitaniada pelo Ministro Gilmar Mendes, a Suprema Corte decidiu por determinar à Câmara Municipal de Mira Estrela que adotasse medidas cabíveis para adequar a composição de vagas para Vereador, porém respeitando os mandatos da atual legislatura. Tratava-se dos denominados "efeitos de inconstitucionalidade pro futuro", nos termos do Ministro Gilmar Mendes.

Não obstante, atingindo a decisão a todos os entes municipais brasileiros, coube ao TSE, por meio de representação do Ministério Público Eleitoral que lhe foi encaminhada e com fundamento no art. 23, IX, do Código Eleitoral e na sua atribuição de assegurar a uniformidade na aplicação das regras do ordenamento eleitoral pátrio, editar Resolução visando regulamentar e divulgar instruções aos poderes municipais sobre o número de candidatos à vereança para as eleições municipais que se avizinhavam no mesmo ano.

A Resolução N. 21.702, publicada em 06 de abril de $2004,{ }^{231}$ a menos de seis meses do início do certame eleitoral, desrespeitou o princípio da anterioridade eleitoral abrigado no art. 16 da Constituição. Não bastasse, o ato determinou que deveriam ser observados os critérios declarados pelo Supremo no julgamento do RE N. 197.917 e anexou tabela ${ }^{232}$ com as novas faixas do tamanho populacional (conforme dados do IBGE de 2003) que resultavam em um número exato de cadeiras nas Câmaras Municipais. Por

\footnotetext{
${ }^{231}$ TSE, Res. N. 21.702, rel. Min. Sepúlveda Pertence, 02.04.04, DJ 06.04.04.

${ }^{232}$ A referida tabela foi extraída pelo TSE do voto do Ministro relator Maurício Corrêa e está estampada no Quadro N. 2 deste capítulo.
} 
meio de mero regulamento, normatizou a questão, legislando positivamente através de ato normativo secundário, como bem aponta M. HERMAN SALEM CAGGIANO ${ }^{233}$.

Incumbiu-se também a Corte Superior Eleitoral de averiguar a adequação da legislação de todos os Municípios brasileiros quanto a sua desconformidade à decisão do STF, determinando, de ofício, inclusive na omissão dessas, o número de cadeiras a serem preenchidas nas Câmaras de Vereadores de cada localidade. Obviamente, pouco se esperava que os Municípios, em menos de seis meses, adotassem providências para o pleito de outubro de 2004, tampouco conseguisse a Justiça Eleitoral averiguar todas as legislações. Restou a possibilidade do simples controle do número de vagas à concorrência do pleito municipal.

Curiosamente, a Resolução em tela previu que, "sobrevindo Emenda Constitucional que altere o art. 29, IV, da Constituição, de modo a modificar os critérios referidos no art. $1^{\circ}$., o Tribunal Superior Eleitoral proverá a observância de novas regras” ${ }^{234}$. Foram necessários pouco mais de cinco anos para que a hipótese viesse a se concretizar.

\subsubsection{A EC-58/09}

Em 23 de setembro de 2009, foi promulgada a Emenda Constitucional N. 58, em sessão conjunta do Congresso Nacional, após uma longa e árdua batalha entre as Casas Legislativas nacionais, que elevou o número atual de Vereadores de pouco mais de 51 mil cadeiras para quase 60 mil postos ${ }^{235}$.

Em 2008, às vésperas do fim do ano legislativo, houve uma tentativa de aprovação da PEC correspondente ${ }^{236}$. Todavia, as Mesas Diretoras do Senado e Câmara entraram em litígio sobre a questão, devido a não promulgação da Emenda pela Mesa Diretora da Câmara, no dia 18 de dezembro de 2008. O então Presidente da Câmara dos

${ }^{233}$ M. HERMAN SALEM CAGGIANO, A fenomenologia dos trânsfugas no cenário político-eleitoral brasileiro, in $O$ voto nas Américas, cit., p. 221.

${ }^{234}$ TSE, Res. N. 21.702, art. 3º., rel. Min. Sepúlveda Pertence, 02.04.04, DJ 06.04.04.

${ }^{235}$ Fala-se em algo próximo a 59.791 vagas de Vereador em todo o país, após a criação de 7.343 novas cadeiras. Cf. O Estado de São Paulo, Senado aprova aumento de Vereadores para 59.791 no País, São Paulo, 18.12.08, disponível (on line) in http://www.estadao.com.br/noticias/, [19.12.08].

${ }^{236}$ Folha de São Paulo, Agência Brasil, STF pede informações à Câmara sobre PEC dos Vereadores, São Paulo, 20.12.08, disponível (on line) in http://www1.folha.uol.com.br/folha/brasil/ult96u481949.shtml., [04.01.09]. Conforme noticiado à época, os parlamentares haviam acordado em cumprir, em apenas um dia de pauta, os prazos para discussão da matéria e votação em dois turnos, visando à promulgação conjunta da referida Emenda. 
Deputados, Arlindo Chinaglia, justificou a recusa, alegando que o Senado havia alterado a proposta aprovada na Câmara, que condicionara a aprovação do acréscimo no número de cadeiras parlamentares a cortes nos gastos. Os Senadores teriam suprimido parte do texto da PEC que reduzia as receitas municipais destinadas às Câmaras de Vereadores ${ }^{237}$ e aprovado o restante da proposta.

Diante da recusa à promulgação conjunta da Emenda pelo Deputado Chinaglia, o então Presidente do Senado Federal, Garibaldi Alves, impetrou Mandado de Segurança no Supremo Tribunal Federal (MS 27.807), com pedido liminar em face do ato do Presidente da Câmara dos Deputados - que obstara a promulgação da PEC - requerendo a sua aprovação pela aquela Casa. O Senador Garibaldi alegou que o procedimento adotado pelo Senado não alterou o conteúdo da proposta ao promulgar parcialmente o texto anteriormente aprovado pela Câmara e remanejar parte - a que se referia ao corte de gastos - para uma PEC paralela. O ato, no entender do Presidente do Senado, era dotado de plena legalidade e com precedentes na promulgação das Emendas da reforma do Judiciário e da Previdência Social.

O Ministro Celso de Mello chegou a requerer informações à Presidência da Câmara, por entender cabível a ação, perante o litígio instaurado e a sustentação do impetrante de que a tramitação haveria se processado regularmente, dentro do procedimento bicameral de aprovação. Por oportuno, o Ministro Celso de Mello negou à imprensa eventual ingerência do Judiciário, pois, de acordo com suas palavras:

\footnotetext{
"a jurisdição constitucional qualifica-se como importante fator de contenção de eventuais excessos, abusos ou omissões alegadamente transgressores do texto da Constituição da República, não importando a condição institucional que ostente o órgão estatal por mais elevada que seja sua posição na estrutura institucional do Estado de que emanem tais condutas" 238 .
}

Sem acordo entre Câmara e Senado e após algumas trocas de farpas entre os Presidentes das duas Casas, com a proximidade do final de ano, o writ somente seria julgado em 2009. No início de março de 2009, a troca do comando no Legislativo fez com

\footnotetext{
${ }^{237}$ Os orçamentos dos Legislativos municipais correspondem a $8 \%$ da receita dos Municípios. A redução aprovada pela Câmara dos Deputados, reduzindo o teto para 4,5\% da receita geraria uma economia estimada em R\$ 1,5 bilhão por ano. Folha de São Paulo, Mônica Bérgamo, Sarney tira do STF ação para aprovar PEC dos Vereadores, São Paulo, 03.03.09, disponível (on line) in http://www.pslnacional.org.br/?p=968., [10.03.09].

${ }^{238}$ Nota divulgada pelo Min. Celso de Mello em 20.12.08. Folha de São Paulo, Agência Brasil, STF pede informações à Câmara sobre PEC dos Vereadores, Brasília, 20.12.08, disponível (on line) in http://www1.folha.uol.com.br/folha/brasil/ult96u481949.shtml., [05.01.09]. Cf. também Folha de São Paulo, Chinaglia espera que STF barre PEC dos Vereadores, Brasília, 22.12.08, disponível (on line) in http://www1.folha.uol.com.br/folha/brasil/ult96u482248.shtml., [05.01.09].
} 
que novos rumos fossem trilhados nesta saga. O novo Presidente do Senado, José Sarney, do PMDB, desistiu da ação no STF e firmou acordo com a Câmara (prevendo que os Senadores revisariam a questão do corte de gastos) para que a proposta voltasse a tramitar na Câmara, presidida pelo Deputado Michel Temer, do mesmo partido do Senador Sarney (PMDB), que motivou a retirada da ação diante de uma “necessidade de 'desjudicializar' a política." $^{, 239}$

Seis meses após, em setembro de 2009, o novo texto a reformar a Constituição foi aprovado, trazendo alterações no conteúdo dos arts. 29, IV e 29-A da Carta Magna. Entre as principais mudanças destacam-se:

a) A exclusão do termo "proporcionalidade" do inciso IV do art. 29, pretendendo tornar perempto o embate sobre a valoração de tal princípio no ordenamento observado na Corte Suprema;

b) A criação de trinta e seis faixas fixas, determinando o exato número de Vereadores, iniciando-se com nove vagas para os Municípios de até 15.000 habitantes, até cinquenta e cinco vagas para aqueles com mais de oito milhões de habitantes ${ }^{240}$.

${ }^{239}$ De acordo com o ex-presidente, "é um absurdo que Senadores e Deputados, eleitos pela população, não tenham capacidade para resolver os conflitos. Não é possível que os homens do Supremo Tribunal Federal continuem resolvendo as coisas por nós". Para o Senador, "o Brasil está descaracterizando a política, que está se judicializando, enquanto a Justiça está se politizando, o que não é bom”. Cf. Folha de São Paulo, Mônica Bérgamo, Sarney tira do STF ação para aprovar PEC dos Vereadores, cit.

${ }^{240}$ A nova redação do art. 29, IV, regulou a material, dispondo da seguinte forma:

IV - para a composição das Câmaras Municipais, será observado o limite máximo de:

a) 9 (nove) Vereadores, nos Municípios de até 15.000 (quinze mil) habitantes;

b) 11 (onze) Vereadores, nos Municípios de mais de 15.000 (quinze mil) habitantes e de até 30.000 (trinta mil) habitantes;

c) 13 (treze) Vereadores, nos Municípios com mais de 30.000 (trinta mil) habitantes e de até 50.000 (cinquenta mil) habitantes;

d) 15 (quinze) Vereadores, nos Municípios de mais de 50.000 (cinquenta mil) habitantes e de até 80.000 (oitenta mil) habitantes;

e) 17 (dezessete) Vereadores, nos Municípios de mais de 80.000 (oitenta mil) habitantes e de até 120.000 (cento e vinte mil) habitantes;

f) 19 (dezenove) Vereadores, nos Municípios de mais de 120.000 (cento e vinte mil) habitantes e de até 160.000 (cento sessenta mil) habitantes;

g) 21 (vinte e um) Vereadores, nos Municípios de mais de 160.000 (cento e sessenta mil) habitantes e de até 300.000 (trezentos mil) habitantes;

h) 23 (vinte e três) Vereadores, nos Municípios de mais de 300.000 (trezentos mil) habitantes e de até 450.000 (quatrocentos e cinquenta mil) habitantes;

i) 25 (vinte e cinco) Vereadores, nos Municípios de mais de 450.000 (quatrocentos e cinquenta mil) habitantes e de até 600.000 (seiscentos mil) habitantes;

j) 27 (vinte e sete) Vereadores, nos Municípios de mais de 600.000 (seiscentos mil) habitantes e de até 750.000 (setecentos cinquenta mil) habitantes;

k) 29 (vinte e nove) Vereadores, nos Municípios de mais de 750.000 (setecentos e cinquenta mil) habitantes e de até 900.000 (novecentos mil) habitantes;

1) 31 (trinta e um) Vereadores, nos Municípios de mais de 900.000 (novecentos mil) habitantes e de até 1.050.000 (um milhão e cinquenta mil) habitantes; 
A polêmica girou em torno da criação de mais de sete mil vagas, devido à proliferação das faixas. Claro ficou que não havia qualquer preocupação em reduzir o número de vagas existentes. Ao contrário, pretendeu o texto aprovado que, retroativamente ao começo da legislatura, no ano 2008, pudessem ser criadas as novas vagas e empossados seriam os suplentes. A previsão legal criada completaria a popularmente chamada "farra dos Vereadores", ao dispor: "Art. $3^{\circ}$. Esta Emenda Constitucional entra em vigor na data de sua promulgação, produzindo efeitos: I - o disposto no art. $1^{\circ}$, a partir do processo eleitoral de 2008; (...)" $)^{, 241}$.

A retroação dos efeitos da Emenda Constitucional causou arrepio à sociedade e aos Ministros do TSE e do STF. O Presidente da Corte Suprema, Ministro Gilmar Mendes chegou a se pronunciar a respeito, dizendo ser "extremamente difícil" que houvesse aplicação imediata da PEC. O Ministro Carlos Ayres Britto, Presidente do TSE, afirmou, por sua vez, que os efeitos da Emenda somente valeriam a partir de 2012. O Ministro Britto alertou que "Emenda Constitucional não pode servir para dar posse a candidatos que perderam as eleições". Justificando que o poder emana do povo, que o exerce através das urnas, considera inviável que uma Emenda Constitucional substitua a vontade do povo, empossando quem perdera as eleições. Para o Ministro, a Emenda

m) 33 (trinta e três) Vereadores, nos Municípios de mais de 1.050 .000 (um milhão e cinquenta mil) habitantes e de até 1.200.000 (um milhão e duzentos mil) habitantes;

n) 35 (trinta e cinco) Vereadores, nos Municípios de mais de 1.200 .000 (um milhão e duzentos mil) habitantes e de até 1.350.000 (um milhão e trezentos e cinquenta mil) habitantes;

o) 37 (trinta e sete) Vereadores, nos Municípios de 1.350 .000 (um milhão e trezentos e cinquenta mil) habitantes e de até 1.500 .000 (um milhão e quinhentos mil) habitantes;

p) 39 (trinta e nove) Vereadores, nos Municípios de mais de 1.500 .000 (um milhão e quinhentos mil) habitantes e de até 1.800.000 (um milhão e oitocentos mil) habitantes;

q) 41 (quarenta e um) Vereadores, nos Municípios de mais de 1.800 .000 (um milhão e oitocentos mil) habitantes e de até 2.400 .000 (dois milhões e quatrocentos mil) habitantes;

r) 43 (quarenta e três) Vereadores, nos Municípios de mais de 2.400 .000 (dois milhões e quatrocentos mil) habitantes e de até 3.000.000 (três milhões) de habitantes;

s) 45 (quarenta e cinco) Vereadores, nos Municípios de mais de 3.000.000 (três milhões) de habitantes e de até 4.000.000 (quatro milhões) de habitantes;

t) 47 (quarenta e sete) Vereadores, nos Municípios de mais de 4.000.000 (quatro milhões) de habitantes e de até 5.000.000 (cinco milhões) de habitantes;

u) 49 (quarenta e nove) Vereadores, nos Municípios de mais de 5.000 .000 (cinco milhões) de habitantes e de até 6.000 .000 (seis milhões) de habitantes;

v) 51 (cinquenta e um) Vereadores, nos Municípios de mais de 6.000 .000 (seis milhões) de habitantes e de até 7.000.000 (sete milhões) de habitantes;

w) 53 (cinquenta e três) Vereadores, nos Municípios de mais de 7.000 .000 (sete milhões) de habitantes e de até 8.000 .000 (oito milhões) de habitantes; e

x) 55 (cinquenta e cinco) Vereadores, nos Municípios de mais de 8.000.000 (oito milhões) de habitantes;

${ }^{241} \mathrm{O}$ inciso I do art. 3o. da EC-58/09 remetia-se ao art. 1o. da mesma Emenda, significando que as vagas poderiam ser imediatamente preenchidas pelos suplentes, com vigência retroativa ao início dos mandatos em 2008. 
poderia ter criado vagas para as próximas eleições e não para a atual legislatura ${ }^{242}$. $\mathrm{O}$ Ministro Britto fundamentou sua posição com a resposta à Consulta N. 1.421/DF, na qual o TSE, de forma unânime, concluiu pela irretroatividade de Emenda Constitucional, aludida na respectiva ementa e excertos dos votos:

"CONSULTA. EMENDA CONSTITUCIONAL QUE REGULAMENTA NÚMERO DE VEREADORES. APLICAÇÃO IMEDIATA DESDE QUE PUBLICADA ANTES DO FIM DO PRAZO DAS CORRESPONDENTES CONVENÇÕES PARTIDÁRIAS.

1.Consignou-se no voto que: '(...) a alteração do número de Vereadores por Emenda Constitucional tem aplicação imediata, não se sujeitando ao prazo de um ano previsto no artigo 16 da Constituição Federal. Esse 'dispositivo está dirigido à legislação eleitoral em si, ou seja, àquela baixada pela União no âmbito da competência que lhe é assegurada constitucionalmente (...)' (RMS N. 20.621/RS, Relator Ministro Marco Aurélio, DJ 221 10193).

2.Ressaltou-se que: 'todavia, a data-limite para a aplicação da Emenda em comento para as próximas eleições municipais deve preceder o inicio do processo eleitoral, ou seja, o prazo final de realização das convenções partidárias.'

3. Consulta respondida positivamente, com a ressalva acima mencionada'., 243

Em 28 de setembro de 2009, o Presidente do TSE encaminhou ofício aos

Presidentes dos Tribunais Regionais Eleitorais, enviando em anexo a resposta à referida Consulta e relembrando que, na ocasião, os Ministros decidiram que somente seria possível a alteração no número de vagas de vereança para as eleições de 2008 caso a PEC fosse promulgada até junho daquele ano, quando se encerrava o prazo para definição dos candidatos pelas convenções partidárias - o que de fato não ocorreu no prazo pretendido.

Nesse polêmico clima instaurado entre Judiciário e Legislativo, o Procurador-Geral da República, Roberto Gurgel, o primeiro a acionar o Supremo Tribunal por meio da ADI N. $4.307^{244}$, seis dias após a publicação da Emenda, considerou a intervenção no sistema eleitoral como casuística e pediu liminarmente à Corte o reconhecimento da inconstitucionalidade do dispositivo que permite o preenchimento imediato das vagas. Fundou-se igualmente na implausibilidade de se alterar o total de Vereadores, considerando-se que, findas as eleições, a engenharia eleitoral para distribuição das cadeiras estaria definida, sendo impossível se cogitar do seu refazimento durante o curso da legislatura, o que implicaria, por vezes, atribuir mandatos a partidos que

242 O Estado de São Paulo, Agência Estado, Câmara aprova PEC dos Vereadores, São Paulo, 22.09.09, disponível (on line) in http://www.abril.com.br/noticias/brasil/camara-aprova-pec-Vereadores-537416.shtml., [29.09.09]; O Estado de São Paulo, Agência Estado, PEC não garante posse de perdedor, diz Ayres Britto, São Paulo, 22.09.09, disponível (on line) in http://www.abril.com.br/noticias/brasil/pec-nao-garante-posseperdedor-diz-ayres-britto-524924.shtml., [29.09.09].

${ }^{243}$ TSE, Consulta N. 1.421/DF, Res. N. 22.556, rel. Min. José Delgado, 19.06.07, DJ 07.08.07.

${ }^{244}$ Notícias STF, Ação Direta de Inconstitucionalidade (ADI) 4307, Brasília, 10.11.09, disponível (on line) in http://www.stf.jus.br/portal/cms/verNoticiaDetalhe.asp?idConteudo=115896, [12.11.09]. STF, ADI-MC N. 4.307/DF, rel. Min. Cármen Lúcia, 02.10.09, DJ 08.10.09. 
perderam as eleições. Essa reviravolta causaria certamente grande instabilidade institucional, alteraria a composição político-partidária às vésperas das eleições nacionais de 2010, afetando seriamente os princípios do Estado Democrático de Direito.

A OAB propôs também uma Ação de Declaração de Inconstitucionalidade - ADI N. 4.310 - com semelhante objeto no dia 01 de outubro de 2009, pedindo igualmente a declaração de inconstitucionalidade do art. $3^{\circ}$. da referida Emenda, fundamentando na quebra de anterioridade prevista no art. $16 \mathrm{CF} / 88$ e no ato jurídico perfeito que são as eleições realizadas em 2008, o que impregnaria a PEC de inconstitucionalidade ao contrariar os arts. 5, 36 e $60, \S 4^{\circ}$., IV, CF/88.

Em 02 de outubro de 2009 a Ministra Cármen Lúcia deu provimento ao pedido liminar na ADI proposta pelo Procurador-Geral, determinado à Justiça Eleitoral que proibisse a posse de qualquer suplente a Vereador para preenchimento das novas vagas criadas pela EC-58. A decisão retroage à data da promulgação da Emenda, considerando nulos os atos de posse ocorridos nesse ínterim. O fundamento para concessão reside no fato das eleições de 2008 serem um processo juridicamente perfeito e acabado. Além disso, não há previsão na Carta Magna para convocação de suplentes para novas vagas de mandato criadas. O que se permite no texto legal é a substituição temporária ou definitiva do titular: a primeira hipótese em casos de licença superior a 120 dias ou afastamento para investidura em funções incompatíveis e a segunda ocorrência definitiva da vacância.

Como algumas Câmaras Municipais haviam já se movimentado em velocidade inusitada, alguns suplentes já haviam sido empossados quando da decisão liminar do STF. Noticiou-se, por exemplo, que os primeiros suplentes empossados no país, apenas dois dias após a promulgação da Emenda, foram André Luiz Guimarães Oliveira, do PT e Luiz Pontes do PR, ambos de Bela Vista, Goiás, Município que, com cerca de 18 mil eleitores, teve o número de vagas na Câmara dos Vereadores aumentadas de nove para onze cadeiras, com a EC-58/09. O novo Vereador do PT afirmou disposição para recorrer de eventual decisão judicial de invalidade da Emenda aprovada pelo Congresso ${ }^{245}$. De outro lado, a Procuradoria Regional Eleitoral em São Paulo estabelecia diretrizes para a impetração de Mandados de Segurança para obstar a posse de suplentes em Municípios do Estado. Em suma, às vésperas do fechamento desta dissertação, vigorava a decisão liminar

${ }^{245}$ G1, Diego Abreu, Liminar do STF impede posse de beneficiados pela PEC dos Vereadores, Brasília, 02.10.09, disponível (on line) in http://g1.globo.com/Noticias/Politica/0,,MUL1327613-5601,00.html; G1, Fausto Carneiro, Primeiro suplente beneficiado pela PEC dos Vereadores já pensa em ser prefeito, Brasília, 28.09.09, disponível (on line) in http://g1.globo.com/Noticias/Politica/0,MUL1321540-5601,00.html., [09.10.09]. 
do STF, que, em sendo confirmada, deixará apenas para as eleições municipais de 2012 o aumento do número de vagas para Vereadores.

Conclui-se que, após tantas idas e vindas, a Emenda Constitucional N. 58, tal como promulgada, ao invés de pacificar o assunto - que bem ou mal estava acalmado desde a decisão do STF em 2004 - ateou fogo gerando novas disputas e embates entre Legislativo e Judiciário. Somada ao tema da fidelidade partidária, a expansão dos Legislativos municipais tornam as matérias eleitorais assunto de grande destaque na mídia e efusivos debates no meio jurídico nesses últimos tempos.

\subsection{A vedação à migração de Prefeitos}

A recente jurisprudência eleitoral apresenta outra importante determinação do TSE relativa às eleições municipais. Apesar da impossibilidade de reeleição para um terceiro mandato eletivo estar assentada na Norma Maior, ${ }^{246}$ com razoável frequência, observa-se na esfera municipal a candidatura a Prefeito de determinado Município pelo ex-Prefeito de Município vizinho. Em logrando sucesso no pleito eleitoral, este agente político conquistaria um novo mandato eletivo, ainda que não no Município em que exerceu seus dois primeiros mandatos, mas em outra cidade da região. Isso decorre da expansão das forças institucionais além das fronteiras dos Municípios, pois essas forças se articulam por territórios ou regiões, de modo que o candidato é renomado e conhecido pelos eleitores de toda uma região e não adstrito aos limites administrativamente impostos. Soma-se a esse quadro a personalização da política nacional, fazendo com que as figuras dos candidatos prevaleçam à do partido e de sua ideologia. Fator, esse, que parece se agravar nos Municípios com menos habitantes. Outro complicador identificado foi a proliferação do número de Municípios gerados a partir da divisão autorizada pela Constituição de 1988, premissa que abriu caminho para que Prefeitos de Municípios que sofreram desmembramento concorressem ao pleito eleitoral subsequente no Município desmembrado.

O TSE entendeu que deveria agir para impedir a burla à reeleição para um terceiro mandato, pois a candidatura de Prefeito do Município-mãe em novo pleito em Município desmembrado vulneraria a livre competição do certame eleitoral, característica

246 Art. 14, § 5º., com redação determinada pela EC-16/97. Constituição Federal da República do Brasil de 05.10 .88 . 
fundamental dos processos eleitorais em regimes verdadeiramente democráticos. A vedação se justificava pois os cidadãos eleitores do Município-filho seriam os mesmos que haviam votado na eleição anterior que elegera o Prefeito candidato. Esse grupo de eleitores certamente sofreria a influência do poder econômico e político do atual Prefeito, que detém a máquina municipal em suas mãos.

A proibição visaria impedir as tentativas dos candidatos ao Executivo Municipal de contornarem o obstáculo imposto à reeleição para um terceiro mandato, algo muito comum nos rincões desta nação, onde ainda se encontram feudos regionais governados por caciques políticos, figura típica do coronelismo que predominou no quadro político nacional no início do século passado.

\subsubsection{Histórico das decisões do TSE acerca das eleições municipais}

Para a compreensão da vedação estabelecida, apresenta-se uma breve cronologia da evolução do entendimento no TSE acerca da reeleição de Prefeitos. A farta jurisprudência anterior ao ano de 1996 apontava a proibição de candidatura de Prefeito eleito no Município-mãe em Município desmembrado e ainda não instalado ${ }^{247}$. Como na época a possibilidade de recondução para cargos do Executivo não constava de nosso ordenamento, a candidatura em Município desmembrado, em eleições subsequentes, se traduzia em reeleição dentro da mesma circunscrição (exercício de mesmo cargo em período eleitoral imediatamente posterior). Tal entendimento foi expresso na ementa da Resolução N. 18.110/92 do TSE:

"PLEITO DE 3.10.92. MUNICÍPIO DESMEMBRADO. PREFEITO DO MUNICÍPIOMÃE. IRREELEGIBILIDADE. A teor do disposto no art. $14, \S 5^{\circ}$., CF, o princípio da irreelegibilidade veda a eleição do prefeito do Município-mãe para chefiar o Executivo do novo Município desmembrado, sobre cujo território tinha abrangência seu domínio de governo, vez que sufragado por eleitores inscritos no mesmo colégio eleitoral que o fizera prefeito na eleição anterior." (grifos nossos) 248

${ }^{247}$ TSE, Res. N. 18.110, rel. Min. José Celso de Mello Filho, 05.05.92, DJ 01.07.92; TSE, Res. N. 19.294, rel. Min. Torquato Jardim, 25.04.95, DJ 05.06.95; TSE, Res. N. 19.528, rel. Min. José Bonifácio de Andrada, 23.04.96, DJ 17.05.96; TSE, Res. N. 12.871, rel. Min. Torquato Jardim, 29.09.92, DJ 29.09.92.

${ }^{248}$ TSE, Res. N. 18.110, rel. Min. José Celso de Mello Filho, 05.05.92, DJ 01.07.92. 
Nitidamente a medida visava coibir fraude à vedação de reeleição (proibida, então, para dois períodos subsequentes), por via indireta. A Emenda Constitucional N. 16, promulgada em 6 de julho de 1997, introduziu a possibilidade de reeleição dos Chefes do Poder Executivo para um único período subsequente, alterando a redação do citado $\S 5^{\circ}$. do art. $14 \mathrm{CF} / 88$. Com a EC-16/97, a proibição da recondução passaria a valer para um terceiro mandato consecutivo.

O conceito de reeleição pairava duvidoso para os detentores de cargos no Legislativo e no Executivo, o que ensejou a Consulta N. 346/97. A resposta restou ementada na Resolução N. 19.970 do TSE, cuja parte atinente ao tema reeleições é abaixo transcrita.

"5. O conceito de reeleição de deputado federal ou de senador implica renovação do mandato para o mesmo cargo, por mais um período subseqüiente, no mesmo "estado" ou no "Distrito Federal", por onde se elegeu. 6. Se o parlamentar federal transferir o domicílio eleitoral para outra unidade da Federação e, aí, concorrer, não cabe falar em reeleição, que pressupõe pronunciamento do corpo de eleitores da mesma circunscrição, na qual, no pleito imediatamente anterior, se elegeu." 249 (grifos nossos)

Assim, tem-se que o conceito de reeleição está intimamente vinculado ao de "mesma circunscrição", ou seja, a reeleição somente se dá dentro de uma mesma circunscrição eleitoral. Daí se extrai a possibilidade da candidatura de um Prefeito em exercício, para o mesmo cargo idêntico em outro território, vizinho ou não, para as eleições seguintes ao segundo mandato, sem vulnerar o postulado da vedação ao terceiro mandato majoritário consecutivo.

Quanto à dúvida sobre a transferência do domicílio eleitoral para participar de pleito em outro Município, objeto da Consulta N. 572/00, respondeu o TSE, na Resolução N. 20.552, que: "O detentor de mandato eletivo que transferiu seu domicílio eleitoral para outra unidade da Federação pode ser candidato para o mesmo cargo pelo seu novo domicílio. ${ }^{250}$ Em referência ao tempo necessário para a alteração de domicílio eleitoral para o Prefeito candidatar-se em outra circunscrição, respondeu o TSE que o candidato deve ter domicílio eleitoral na circunscrição em que pretende concorrer pelo menos um ano antes do pleito, em respeito ao art. 55 do Código Eleitoral.

Por ocasião da resposta à Consulta N. 841/RJ, o TSE viria a firmar seu entendimento quanto à migração de Prefeitos após a introdução da reeleição para dois

\footnotetext{
${ }^{249}$ TSE, Consulta N. 346, Res. N. 19.970, rel. ac. Min. Neri da Silveira, 18.09.97, DJ 21.10.97.

${ }^{250}$ TSE, Consulta N. 572, Res. N. 20.552, rel. Min. Edson Vidigal, 15.02.00, DJ 24.03.00.
} 
mandatos eletivos em nosso ordenamento. A Consulta foi formulada pelo Presidente do diretório regional do PSDB de Mangaratiba e inquiriu sobre a necessidade de desincompatibilização ou renúncia do Prefeito em exercício em uma comarca para ser candidato em outra lindeira. O relator da Resolução N. 21.297/02 do TSE, Ministro Fernando Neves, discordou do parecer da assessoria especial da Presidência do Tribunal e respondeu que a candidatura a cargo de Prefeito em Município diverso, lindeiro ou não, deveria observar a desincompatibilização no prazo de seis meses anteriores ao pleito, na melhor interpretação do art. $14, \S 6^{\circ}$., da Constituição da República, segundo o relator ${ }^{251}$. A mesma regra de desincompatibilização seria válida caso o Prefeito em exercício resolvesse se candidatar ao cargo de Vereador na mesma comarca. A construção decorre do conceito de "outro cargo" adotado pelo Ministro relator da Resolução N. 21.297/02 do TSE, que aduziu:

\footnotetext{
"Penso que o cargo é prefeito de tal Município, e não somente prefeito. Assim, a candidatura a cargo de prefeito de outro Município, vizinho ou não, caracteriza candidatura a outro cargo, devendo ser observada a regra do art. $14, \S 6^{\circ}$., da Constituição da República, ou seja, a desincompatibilização seis meses antes do pleito." 252 (grifos nossos)
}

Quanto à viabilidade de esposa do Prefeito em exercício se candidatar ao cargo de Chefe do Executivo municipal, primeiramente esse Prefeito deve preencher os requisitos para reeleição e, concomitantemente, deve se descompatibilizar. ${ }^{253}$ Também se assentou na Corte Eleitoral que, "para cargo diverso, em havendo desincompatibilização do chefe do Executivo do Município-mãe, era irrestrita a possibilidade de candidatura tanto deste como do seu cônjuge ou parentes, exigindo-se apenas a desincompatibilização no prazo legal". 254

Na resposta à Consulta N. 926/DF, o relator Ministro Fernando Neves definiu que o tempo era fator a desconstituir a premissa de burla à reeleição para um terceiro mandato na hipótese em que o Prefeito reeleito viesse a concorrer ao mesmo cargo em Município desmembrado há dois ou mais pleitos municipais. O inverso também seria permitido: Prefeito reeleito no Município desmembrado há dois ou mais pleitos

\footnotetext{
${ }^{251}$ TSE, Consulta N. 841/RJ e Res. N. 21.297, rel. Min. Fernando Neves, 12.11.02, DJ 27.02.03.

${ }^{252}$ TSE, Consulta N. 841/RJ e Res. N. 21.297, rel. Min. Fernando Neves, 12.11.02, DJ 27.02.03.

${ }^{253}$ Cf. TSE, Res. N. 21.297, rel. Min. Fernando Neves, 12.11.02, DJ 27.02.03, cuja ementa traz: “A esposa do Prefeito poderá se candidatar a cargo no Executivo Municipal se ele puder ser reeleito e tiver se afastado do cargo seis meses antes da eleição (Precedente: STF, Ac. N. 19.442, rel. Min. Ellen Gracie, 21.8.2001,)". Em se candidatando à Vereadora municipal, vale a regra da mesma Resolução: "A esposa do Prefeito poderá se candidatar a cargo no Legislativo Municipal se ele tiver se afastado do cargo seis meses antes da eleição".

254 TSE, Res. N. 21.465, rel. Min. Fernando Neves, 19.08.03, DJ 14.10.2003.
} 
municipais, pode se candidatar ao cargo de Prefeito do Município-mãe. Para tanto, era devida a observância do dispositivo do art. $14, \S 6^{\circ}$., da Constituição Federal, "bem como das exigências de filiação partidária e domicílio eleitoral, na circunscrição em que se pretende concorrer, pelo menos um ano antes do pleito." 255 Tal permissão decorre da jurisprudência do TSE, que - conforme explanado acima - se funda na premissa de que os eleitores do Município desmembrado haviam votado no pleito que elegeu o atual Prefeito. O Ministro Neves asseverou que tal influência desaparece após a instalação do Município desmembrado, dada a autonomia administrativa que passaria a adquirir, o que se observaria após o período equivalente a um mandato eletivo. Igualmente, considerou que se esvanece a hipótese de uso da máquina administrativa de que o Prefeito dispõe, após esse lapso temporal. Descaracterizada a qualidade de "Município desmembrado", passaria a ser qualificado tão somente como "Município vizinho", devendo o candidato Prefeito, reeleito ou não, desincompatibilizar-se para se candidatar no prazo legal. O cargo que pleiteia nessa hipótese, apesar de semelhante ao que exerce, é, na melhor jurisprudência da Corte $^{256}$, considerado "outro cargo". Deste modo, permite-se que Prefeito reeleito de um Município seja eleito em outro Município nas eleições seguintes sem violar a regra da vedação ao terceiro mandato.

Com a Instrução N. 73, veiculada pela Resolução N. 21.608/04 do TSE em seu art. 12, caput, restou assentado para as eleições municipais de 2004 que, para concorrer a "outros cargos", seria necessária a renúncia do mandato eletivo vigente até seis meses antes do pleito, seguindo a regra constitucional da desincompatibilização. Pelo $§ 1^{\circ}$. do mesmo artigo, fixou-se a irrelegibilidade do Prefeito reeleito para o mesmo cargo - e para o cargo de vice - na mesma circunscrição. E, pelo $\S 2^{\circ}$., estabeleceu-se que:

\footnotetext{
"O prefeito, reeleito ou não, que, em eleição consecutiva, pretenda candidatar-se em outro Município, deverá observar a regra do art. 14, § $6^{\circ}$, da Constituição da República, bem como as exigências de filiação partidária e domicílio eleitoral na circunscrição em que pretenda concorrer, pelo menos um ano antes do pleito, desde que o Município não tenha sido criado por desmembramento, incorporação ou fusão daquele onde ocupou o cargo." 257
}

\footnotetext{
${ }^{255}$ TSE, Consulta N. 926/DF e Res. N. 21.465, rel. Min. Fernando Neves, 19.08.03, DJ 14.10.2003; TSE, Res. N. 21.379, rel. Min. Fernando Neves, 15.04.03, DJ 06.06.03.

${ }^{256}$ TSE, Res. N. 21.297, rel. Min. Fernando Neves, 12.11.02, DJ 27.02.03. A premissa foi confirmada pela Res. N. 21.696, na qual o Min. relator Fernando Neves afirmou: "frise-se que a "candidatura a cargo eletivo em outro Município, vizinho ou não, caracteriza candidatura a outro cargo'. Por conseguinte, o Prefeito de um Município pode ser candidato a idêntico cargo em outro Município em pleito subseqüente ao segundo mandato sem violar a regra insculpida no art. $14 \S 5^{\circ}$. da vigente Constituição Federal". (grifos nossos). Cf. TSE, Res. N. 21.696, rel. Min. Fernando Neves, 30.03.04, DJ 26.04.04.

${ }^{257}$ TSE, Res. N. 21.608, rel. Min. Fernando Neves, 05.02.04, DJ 09.03.04.
} 
A regra, fixada desde a interpretação efetivada pelo TSE na Resolução N. 21.297/02, impõe a desincompatibilização, a mudança de domicílio eleitoral um ano antes do pleito, além de estabelecer as exigências de filiação partidária no mesmo prazo, para o Prefeito que queira pleitear cargo semelhante, em eleição consecutiva, em outra circunscrição, vizinha ou não. Em se tratando de candidatura para cargo de Chefe do Executivo de Município desmembrado, incorporado ou fundido há não mais que um pleito eleitoral, mantinha-se a proibição de se conduzir a mais um mandato ${ }^{258}$. Por fim, na hipótese de candidatura de Prefeito para cargo idêntico em Município desmembrado, incorporado ou fundido há mais que um pleito eleitoral, aplica-se a regra "para outro cargo" do $\S 2^{\circ}$ da Resolução N. 21.608/04, conforme decidido na Resolução N. $21.465 / 03^{259}$.

\subsubsection{A recente decisão do TSE - Fim dos "Prefeitos itinerantes"}

Ao final do ano de 2008, o plenário do TSE colocou um ponto final na carreira dos chamados "Prefeitos itinerantes" - aqueles que cumprem dois mandatos em um Município e mudam para um vizinho para novo período de oito anos no cargo de Prefeito. Trata-se do julgamento do Recurso Especial Eleitoral ${ }^{260}$ em ação de impugnação de registro de candidatura interposto pelo Prefeito José Rogério Cavalcante Farias ${ }^{261}$. O político se perpetuou na profissão de Prefeito por doze anos, sendo os oito primeiros no governo municipal de Barra de Santo Antônio-AL e na legislatura a se findar em 2008, em Porto de Pedras-AL, Município para o qual pretendia a reeleição. Decisão semelhante também negou registro de candidatura a José Petrúcio Oliveira Barbosa, candidato a Prefeito de Palmeira dos Índios (AL) para a legislatura de $2009^{262}$. Ambos pretendiam

\footnotetext{
${ }^{258}$ Como visto, a regra inicialmente propugnada pela Res. N. 18.110 foi readaptada após a EC-16/97 pela Res. N. 21.297. TSE, Res. N. 21.297, rel. Min. Fernando Neves, 12.11.02, DJ 27.02.03.

${ }^{259}$ TSE, Res. N. 21.465, rel. Min. Fernando Neves, 19.08.03, DJ 14.10.2003.

${ }^{260}$ TSE, RESPE N. 32.507, rel. Min. Eros Grau, 17.12.2008, DJ 17.12.08. O recurso fora interposto sob a alegação de divergência jurisprudencial entre o TRE-AL e o TSE, com fundamento nas Res. N. 21.927, 21.465 e 21.608 do TSE. Decisão: O Tribunal, por maioria, desproveu o Recurso, nos termos do voto do relator. Vencidos os Ministros Marcelo Ribeiro e Arnaldo Versiani. Composição do Plenário: Ministros Carlos Ayres Britto, Joaquim Barbosa, Eros Grau, Felix Fischer, Fernando Gonçalves, Marcelo Ribeiro e Arnaldo Versiani.

${ }^{261}$ O Prefeito Rogério Farias (que é irmão de finada personagem política nacional: Paulo César Farias, o "PC Farias") teve sua candidatura impugnada por decisão de primeira instância da Justiça Eleitoral, da qual recorreu, interpondo Recurso Especial Eleitoral para reverter o julgado.

${ }^{262}$ TSE, RESPE N. 32.539, rel. ac. Min. Carlos Britto, 17.12.08, DJ 17.12.08. Decisão: “O Tribunal, por maioria, desproveu Recurso, nos termos do voto do Ministro Carlos Ayres Britto, que redigirá o acórdão.
} 
concorrer a um novo mandato para o mesmo cargo, o que se daria mediante transferência de domicílio eleitoral.

A decisão do TSE no julgamento de ambos os Recursos Especiais Eleitorais, ficou assim ementada:

"RECURSO ESPECIAL. ELEIÇÕES 2008. REGISTRO CANDIDATURA. PREFEITO. CANDIDATO À REELEIÇÃO. TRANSFERÊNCIA DE DOMICÍLIO PARA OUTRO MUNICÍPIO. FRAUDE CONFIGURADA. VIOLAÇÃO DO DISPOSTO NO $\S 5^{\circ}$ DO ART. 14 DA CF. IMPROVIMENTO.

1. Fraude consumada mediante o desvirtuamento da faculdade de transferir-se domicílio eleitoral de um para outro Município, de modo a ilidir-se a incidência do preceito legal disposto no $\$ 5^{\circ}$ do artigo 14 da CF. 2. Evidente desvio da finalidade do direito à fixação do domicílio eleitoral.", 263

Seguindo o voto do Ministro Eros Grau, a maioria dos Ministros no TSE determinou a impossibilidade de "obtenção de um terceiro mandato em outro Município vizinho ou não, por Prefeito eleito e reeleito em outra localidade, por meio de transferência de domicílio eleitoral". Segundo o TSE, essa migração "representaria o desvirtuamento deste instrumento eleitoral e a consolidação dos chamados 'Prefeitos itinerantes" e se fundamenta no art. 14 da Constituição Federal, de acordo com o Presidente da Corte Eleitoral, Ministro Carlos Ayres Britto. O entendimento parte de interpretação, pela qual o dispositivo permite "apenas uma reeleição do Prefeito, proibindo o exercício de um terceiro mandato mesmo em Municípios diferentes". Para o Ministro "somente é possível eleger-se ao cargo de Prefeito por duas vezes consecutivas. Após isso, apenas permite-se, respeitado o prazo de desincompatibilização de seis meses, a candidatura para outro cargo"264. Do mesmo entendimento compartilhou o Ministro Eros Grau, para quem a reeleição só é permitida para os Chefes do Executivo para um "único período subsequente", pois a regra constitucional veda a perpetuação no cargo, que no caso em tela estaria sendo fraudada. O relator considerou configurar a situação nos autos "exemplar desvirtuamento da finalidade do direito à fixação do domicílio eleitoral", empregado para burlar a vedação à reeleição.

Vencidos o Ministro relator Marcelo Ribeiro e o Ministro Arnaldo Versiani. Votaram com o Ministro Carlos Ayres Britto os Ministros Joaquim Barbosa, Eros Grau, Felix Fischer e Fernando Gonçalves. (...). Nova orientação jurisprudencial do Tribunal Superior Eleitoral, firmada no Respe 32.507." V. Nota N. 260.

${ }^{263}$ TSE, RESPE N. 32.507, rel. Min. Eros Grau, 17.12.2008, DJ 17.12.08; TSE, RESPE N. 32.539, rel. ac. Min. Carlos Britto, 17.12.08, DJ 17.12.08.

${ }^{264}$ TSE, RESPE N. 32.539, rel. ac. Min. Carlos Britto, 17.12.08, DJ 17.12.08. 
A farta jurisprudência da Corte Eleitoral apresentada neste estudo foi a base do voto divergente do Ministro Marcelo Ribeiro ${ }^{265}$. Lembre-se a Resolução N. 21.465/03 onde se reafirmou que a candidatura para Prefeito em outro Município, desde que não desmembrado há menos de duas legislaturas, apesar do cargo ser idêntico, era considerado como "outro cargo", pois se tratava de "outra circunscrição"266. A nova interpretação do TSE em 2008 atribuiu novo sentido à candidatura a "outro cargo", ou seja, a expressão "outro cargo" passaria a significar qualquer mandato legislativo, ou qualquer outro de chefia do Executivo, que não o de Prefeito Municipal.

Com a decisão, a Corte Eleitoral tomou novos rumos quanto à migração dos Prefeitos e duas consequências nefastas apontam no horizonte: a divergência entre os Tribunais Regionais e destes com a Corte Superior, e; uma chuva de ações na Justiça Eleitoral pleiteando a perda dos mandatos de vários dos Prefeitos recém-empossados em 2009. É o caso do Prefeito de Florianópolis, que estaria exercendo seu quarto mandato consecutivo como Prefeito. Os dois primeiros pelo Município de São José (1997-2004) e os dois seguintes por Florianópolis (2005-2011). Em julho de 2009, o TRE-SC absolveu o Prefeito da perda do mandato, pois entendeu o Tribunal estar prestigiando a segurança jurídica. Sua candidatura teria sido registrada na prevalência da sólida jurisprudência anteriormente firmada pela Corte Superior. Em agosto de 2009, a coligação opositora ao Prefeito no pleito de 2008 interpôs Recurso Especial Eleitoral, que foi distribuído para a relatoria do Ministro Lewandowski ${ }^{267}$.

A divergência entre o Tribunal Superior Eleitoral e os Tribunais Regionais Eleitorais também se processaria no sentido inverso. O TRE-PI decretou a perda do mandato por reconhecimento do quarto mandato consecutivo do Prefeito Joãozinho Felix, do PPS. Tendo sido o Chefe do Executivo do Município de Jatobá do Piauí por oito anos seguidos, o Prefeito cumpriu mais dois mandatos eletivos na cidade de Campo MaiorPI. Todavia, o TSE reverteu a decisão do TRE-PI no julgamento de 22 de outubro de $2009^{268}$, provendo o recurso interposto.

\footnotetext{
${ }^{265}$ O Ministro citou, em especial, as Res. do TSE N. 21.927, 21.465.

266 TSE, Res. N. 21.465, rel. Min. Fernando Neves, 19.08.03, DJ 14.10.2003.

${ }^{267}$ TSE, RESPE N. 35.906, pendente de julgamento. Centro de divulgação da Justiça Eleitoral disponível (on line) in: http://agencia.tse.gov.br, [20.11.09].

${ }^{268}$ TSE, RESPE N. 35.741, rel. Min. Marcelo Ribeiro, 22.10.09, DJ 18.11.09. O Tribunal, por unanimidade, proveu o Recurso para extinguir o processo, nos termos do voto do relator. Votaram com o relator os Ministros Arnaldo Versiani, Ricardo Lewandowski, Cármen Lúcia, Felix Fischer e Fernando Gonçalves.
} 
Em suma, pode-se perceber, em mais esta oportunidade, que a habilidade interpretativa das Cortes pátrias leva a repentinas alterações no entendimento até então prevalecente, causando extrema confusão e insegurança jurídica às instituições democráticas.

\subsection{A cláusula de barreira ${ }^{269}$}

A Constituição brasileira de 1946 é considerada a Carta que deu início ao primado dos partidos políticos na República Federal. Seu caráter democrático balizava a criação e atuação dos partidos, prevendo expressamente o dever de respeito ao regime democrático que por ela se instalava, com base nos direitos fundamentais do ser humano e no pluralismo partidário $^{270}$.

A Constituição Federal vigente, restabelecendo a democracia, procurou alçar os partidos políticos à condição de instrumentos necessários à preservação do Estado Democrático de Direito, pela instituição de princípios democráticos tais como a liberdade de criação, fusão, incorporação e extinção das agremiações políticas, observados os preceitos do pluralismo, a prestação de contas à Justiça Eleitoral e o funcionamento parlamentar em estrita legalidade ${ }^{271}$.

Porém, foi justamente na Carta de 1967 - tida como a Norma Maior que intermediou dois períodos de predominância democrática, com a instauração de um regime autoritário $^{272}$ - que se versou pioneiramente sobre a matéria atinente à cláusula de barreira partidária, como condição para se ocuparem as vagas parlamentares. Encontram-se no art. 149, VII, de seu texto original as fórmulas matemáticas então propugnadas para a organização, o funcionamento e a extinção dos partidos, que estabeleciam, pela primeira

\footnotetext{
${ }^{269}$ A cláusula de barreira ou cláusula de exclusão pode ser conceituada como a norma que impede a existência ou a representação parlamentar do partido político que não alcance certas condições de votação. É destinada à contenção do número de partidos, que tende a se expandir nos sistemas proporcionais. Cf. O. MezZaroba, Introdução ao Direito Partidário Brasileiro, 2a . ed., Rio de Janeiro, Lumen Juris, 2003.

${ }^{270}$ Cf. Art. 141, $\S 13^{\circ}$., CF/46. Cf. M. G. FerReIRA FILHO, Curso de Direito Constitucional, $31^{\mathrm{a}}$. ed., Saraiva, São Paulo, 2008, p. 124-129. Cf. J. Afonso DA SILVA, José, Curso de Direito Constitucional Positivo, cit., p. 396: "no período de 1946 a 1965 que floresceu um sistema partidário com alguma institucionalização efetiva", com base em partidos de âmbito nacional.

${ }^{271}$ Cf. Arts., $1^{\circ}$.,V, $5^{\circ}$., XVII, 17, CF/88. Cf. A. DE MORAES, Direito Constitucional, cit., p. 26.

272 J. Afonso DA SIlva, Curso de Direito Constitucional Positivo, cit., p. 83-87.
} 
vez no ordenamento nacional, uma exigente cláusula de barreira, atingindo não só a Câmara dos Deputados, como também o Senado ${ }^{273}$.

Com a EC-1 de 1969, a exigência de percentual mínimo de votos se reduziria de $10 \%$ para $5 \%$ e a distribuição pelos Estados se fixaria em sete unidades da Federação, com o mínimo de 7\% em cada um deles, ao invés dos dois terços pelos Estados com mínimo de $10 \%$. Essas novas razões seriam admitidas para as eleições da Câmara dos Deputados, uma vez excluído o pleito para o Senado Federal.

Nova Emenda, em $1978^{274}$, manteve o percentual de 5\% do eleitorado e aumentou para nove Estados com mínimo de 3\% a distribuição necessária dos votos. Com a EC-25/85, já à época da abertura política, o art. 152 que comandava a cláusula de barreira sofreu nova alteração, fazendo constar do texto constitucional que:

“Art. 152, $\S 1^{\circ}$. Não terá direito a representação no Senado Federal e na Câmara dos Deputados o partido que não obtiver o apoio, expresso em votos, de $3 \%$ (três por cento) do eleitorado, apurados em eleição geral para a Câmara dos Deputados e distribuídos em, pelo menos, 5 (cinco) Estados com o mínimo de $2 \%$ (dois por cento) do eleitorado de cada um deles."

Inovou-se com a citada Emenda ao dispor de forma curiosa sobre as consequências do não cumprimento da cláusula de barreira, ao estabelecer na redação do $\S$ $2^{\circ}$. do aludido artigo que os candidatos eleitos por partidos que não lograssem atingir os percentuais exigidos, poderiam ter seus mandatos preservados, mediante opção, no prazo de sessenta dias, por qualquer um dos partidos que houvesse superado a cláusula de barreira $^{275}$.

Destaca-se, pelo exposto, o tratamento constitucional dado à matéria, que, embora remetesse à lei federal, mantinha preservados os princípios constitucionais que foram instituídos, ao tratar da representação parlamentar e da criação e extinção dos partidos.

\footnotetext{
${ }^{273}$ Art. 149, CF/67: “A organização, o funcionamento e a extinção dos Partidos Políticos serão regulados em lei federal, observados os seguintes princípios: (...)VII - exigência de $10 \%$ do eleitorado que haja votado na última eleição geral para a Câmara dos Deputados, distribuídos em dois terços dos Estados, com o mínimo de $7 \%$ em cada um deles, bem assim dez por cento de Deputados, em, pelo menos, um terço dos Estados, e 10\% de Senadores;"

${ }^{274}$ EC- $11 / 78$, art. $152, \S \S 2^{\circ}$. , II.

${ }^{275} \mathrm{O}$ dispositivo em menção mostra, ademais, o descolamento da figura do candidato à qualquer ideologia político-partidária, permitindo-se a mudança de bandeira como forma de preservação do mandato, denotando, o forte personalismo da cultura política nacional.
} 
A Lei Maior de 1988 assegurou aos partidos políticos autonomia na definição de sua estrutura interna ${ }^{276}$, de sua organização e funcionamento, colocando, à semelhança da Lei Fundamental de Bonn de 1949, o estatuto partidário como instrumento a estabelecer normas de disciplina e fidelidade ${ }^{277}$. Afirma-se a liberdade partidária sem, contudo, deixar de impor-lhe condicionamentos, conforme lembra J. AFONSO DA SILVA ${ }^{278}$. Assim, além do respeito aos princípios já citados, exige-se o caráter nacional para criação das agremiações e deixa à lei a atribuição de estabelecer as regras para o funcionamento parlamentar e definir os elementos que proporcionam a amplitude nacional dos partidos, vedando - como contraponto à liberdade de associação - organizações paramilitares.

O dispositivo do inciso IV do art. 17, CF/88, pelo qual "a lei determinará o funcionamento parlamentar", insere-se na seara do "sistema de controles dos partidos brasileiros", conforme denominação de J. AfOnso DA SILVA. De acordo com o mestre, existem dois tipos de controles: o qualitativo e o quantitativo.

O primeiro requer a conformidade da ideologia partidária ao Estado Democrático de Direito, de tal modo que não são admitidas agrupações que atentem ao regime político vigente. Em outros termos, coíbe-se a existência de partidos de tendências autoritárias, pois o princípio do pluralismo é fundamental para a democracia. Em suma, os partidos devem estar concordes com as "regras do jogo", constitucionalmente estabelecidas.

Em referência ao controle quantitativo, nota-se que, segundo o entendimento de J. AFONSO DA SILVA, “a Constituição, (...), praticamente não impôs controle quantitativo aos partidos, mas contém a possibilidade que venha a existir por via de lei, (...)". E continua o autor: "É que o controle quantitativo se realiza pela instituição de mecanismos normativos que limitam as possibilidades de ampliação, ad libitum, dos partidos políticos, e atua não no momento da organização, mas no seu funcionamento". Esse controle pode, ainda segundo o autor, "consistir na exigência de que obtenham, em eleições gerais, para a Câmara dos Deputados, o apoio expresso em votos de uma

\footnotetext{
${ }^{276}$ V. TSE, Consulta N. 1.251/DF, na qual o Tribunal definiu que a Justiça Eleitoral é incompetente para julgar matéria interna corporis dos partidos políticos. TSE, Consulta N. 1.251/DF, Res. N. 22.213, rel. Min. Carlos Britto, 30.05.06, DJ 20.06.06.

${ }^{277}$ Art. 17, § $1^{\circ}$., CF/88. O estatuto partidário foi também inovação nas Cartas estrangeiras do século XX. M. G. FERREIRA FILHO aponta, além da Constituição da República Federativa alemã, as Constituições francesa de 1958, portuguesa de 1976 e espanhola de 1978. V. Os partidos políticos nas constituições democráticas, Belo Horizonte, RBEP, 1966, p. 38-62.

${ }^{278}$ J. AfOnso DA SILVA, Curso de Direito Constitucional Positivo, cit., p. 404-405.
} 
percentagem mínima do eleitorado nacional em certo número de Estados, (...)” ${ }^{279}$. A partir do ensinamento, nitidamente se extrai a autorização constitucional para que a lei ordinária estabeleça a cláusula de barreira.

A Lei N. 9.096, aprovada e publicada em 19 de setembro de 1995, veio regulamentar os arts. 17 e 14, $\S 3^{\circ}$, inciso V, da Constituição Federal de 1988, dispondo sobre os partidos políticos. E ao fazê-lo, reintroduziu no ordenamento a cláusula de desempenho ao regular sobre o funcionamento parlamentar do seguinte modo:

"Art. 13. Tem direito a funcionamento parlamentar, em todas as Casas Legislativas para as quais tenha elegido representante, o partido que, em cada eleição para a Câmara dos Deputados obtenha o apoio de, no mínimo, cinco por cento dos votos apurados, não computados os brancos e os nulos, distribuídos em, pelo menos, um terço dos Estados, com um mínimo de dois por cento do total de cada um deles."

Em comparação com as exigências que anteriormente habitaram nosso ordenamento, a Lei dos Partidos Políticos buscou o meio termo. Previu a necessidade de $5 \%$ por cento, incrementando em dois pontos percentuais a exigência dada pela EC-25/85, porém aquém dos $10 \%$ outrora requeridos. Já quanto ao cálculo da distribuição dos votos pelos Estados, o fez nos menores níveis, requerendo apenas um terço dos Estados (o equivalente a nove, após a Carta de 1988) e o mínimo de $2 \%$ em cada ente federado. A cláusula de barreira ficara, portanto, ausente do ordenamento pátrio desde a promulgação da Constituição cidadã em 1988 e retornaria para a legislatura de $2007^{280}$. O que teria feito o Legislativo a retomar um dispositivo que fora relacionado com os ideais autoritários da Carta de 1967 ?

Comparando-se as legislaturas nas décadas de 80 e 90, CARLOS RANULFO MELO constata que:

\footnotetext{
"a diferença observada entre as duas décadas pode ser explicada pelo fato de que, nos anos 80, a reacomodação política dos congressistas implicou a criação de novos partidos, ao passo que, no período seguinte, o que mais se observou foi o trânsito entre as legendas existentes." 281
}

\footnotetext{
${ }^{279}$ J. AfOnSo DA SIlva, Curso de Direito Constitucional Positivo, cit., p. 400 e 407. A posição do autor é reafirmada quando profere que: "A Constituição não mais traz exigências desse tipo"- referindo-se ao controle quantitativo - "mas as admite, quando confere à lei o estabelecimento de preceitos de funcionamento parlamentar dos partidos (art. 17, IV)."

${ }^{280}$ De acordo com os arts. 56 e 57 das Disposições Finais e Transitórias da Lei dos Partidos Políticos, a aplicação da cláusula de barreira teria sua eficácia projetada no tempo, mitigando suas consequências até a plena eficácia, que se daria na legislatura a se iniciar em 2007, levando em consideração o resultado das eleições gerais de 2006. Lei 9.096 de 19 de setembro de 1995.

${ }^{281}$ C. RANUlFo MELO, Retirando as cadeiras do lugar, UFMG, Belo Horizonte, 2004, p. 136.
} 
$\mathrm{O}$ autor traz em sua obra preciosos dados sobre a migração partidária e retrata que, na legislatura da Câmara dos Deputados de 1983-1987, o número de partidos que elegeram ao menos um parlamentar aumentou de cinco para doze, e viria a atingir dezenove no início da legislatura de 1991-1995, quando estabilizaria e chegaria a se reduzir levemente durante a década de 90, para somar dezesseis legendas ao final do ano de $2002^{282}$. O estudo das cinco legislaturas do período mostra que o "bipartidarismo imperfeito" oriundo do regime militar e que predominaria até o início dos anos 80, cederia espaço a um multipartidarismo com agremiações de portes pequeno e médio na década seguinte $^{283}$. Já para o pleito de 2006, concorreu um número expressivamente maior de legendas: vinte e nove partidos regularmente inscritos no TSE, sendo que vinte e um deles lograram eleger ao menos um Deputado Federal.

A proliferação de partidos desde a abertura política e o fim do bipartidarismo foram retratados por J. AFONSO DA SILVA. O autor identificou, nas eleições de outubro de 2002, a participação de quatro grandes forças, cinco partidos médios e médio-altos, dois pequenos e a grande maioria composta de: quatro partidos "minúsculos"; quatro "minipartidos" e; oito "micropartidos ou nanicos" - empregando-se sempre os termos do autor. Estes últimos são aqueles que não fizeram nenhum parlamentar federal ${ }^{284}$. E é justamente este fato que responde à indagação supra posta. A existência de inúmeras agremiações políticas inexpressivas, chamadas de "legendas de aluguel” ensejou a ação do legislador ordinário, restringindo o número de partidos passíveis de funcionarem no Congresso. A iniciativa se deu pela recuperação da fórmula da cláusula de barreira, que anteriormente habitava os textos constitucionais pretéritos, visando extirpar os partidos denominados "nanicos".

282 C. RANUlfo Melo, Retirando as cadeiras do lugar, cit., p. 136. Os dados trazidos por J. AFONSO DA SILVA diferem um pouco: o jurista menciona a existência de vinte partidos nas eleições de 1994 e 1998 e dezenove nas eleições de outubro de 2002. J. Afonso DA SILVA, Curso de Direito Constitucional Positivo, cit., p. 393-398.

${ }^{283}$ De acordo com J. AFONSO DA SILVA, na vigência da CF de 1946, três eram as forças partidárias de caráter nacional: o Partido Social Democrático (PSD), a União Democrática Nacional (UDN) e o Partido Trabalhista Brasileiro (PTB), que se somavam a pequenas agremiações regionais. Todos foram extintos pelo AI-2 de 1965, que levou, segundo o autor, ao bipartidarismo "artificial", composto por MDB e ARENA, que deixariam de existir em 1979, quando começa a reestruturação partidária. J. AFONSO DA SILVA, Curso de Direito Constitucional Positivo, cit., p. 396.

${ }^{284}$ J. AfOnSo DA SILVA, Curso de Direito Constitucional Positivo, cit., p.397. 


\subsubsection{As consequências de eventual aplicação da cláusula de barreira às eleiç̃̃es ocorridas em 2006}

Imposta pela Lei dos Partidos Políticos "de forma tênue e atípica" segundo M. HeRman SALEM CAGGIANO ${ }^{285}$ - a cláusula de barreira jamais viria a ter aplicação concreta no pós-Constituição de 1988. A previsão do art. 57 da referida norma deixava a aplicação para a legislatura que se iniciava em 2006 - onze anos depois da criação da lei - da plena incidência da cláusula de barreira a eliminar os partidos de reduzida representatividade na Câmara dos Deputados.

A perda do direito de funcionamento parlamentar impunha como principal restrição a participação no rateio de $99 \%$ dos recursos do Fundo Partidário (que em 2006 somaram R\$ 118 milhões), além do impedimento a constituir bancada, a participar de CPI e de comissões permanentes e a ter liderança partidária na Mesa da Câmara. Constava da redação original do art. 41 da referida norma:

Art. 41. O Tribunal Superior Eleitoral, dentro de cinco dias, a contar da data do depósito a que se refere o $\S 1^{\circ}$ do artigo anterior, fará a respectiva distribuição aos órgãos nacionais dos partidos, obedecendo aos seguintes critérios:

I - um por cento do total do Fundo Partidário será destacado para entrega, em partes iguais, a todos os partidos que tenham seus estatutos registrados no Tribunal Superior Eleitoral;

II - noventa e nove por cento do total do Fundo Partidário serão distribuídos aos partidos que tenham preenchido as condições do art. 13, na proporção dos votos obtidos na última eleição geral para a Câmara dos Deputados.

Como se percebe, os partidos com maior representatividade na Câmara criaram um dispositivo que lhes permitia abocanhar a quase totalidade do Fundo Partidário, asfixiando financeiramente os partidos de pequeno porte. Com isso, os partidos obstados teriam apenas $1 \%$ a dividir, ou seja, pouco mais de $\mathrm{R} \$ 1$ milhão para $14 \operatorname{dos} 21^{286}$ partidos com representantes na Câmara dos Deputados, ou seja, aproximadamente 56 mil reais para cada partido anualmente. Os sete partidos que superaram a barreira receberiam mais de R \$ 16 milhões por ano cada um.

\footnotetext{
${ }^{285}$ M. HeRmAn SAlEM CAGgIANO, A fenomenologia dos trânsfugas no cenário político-eleitoral brasileiro, in $O$ voto nas Américas, cit., p. 223.

${ }^{286}$ Existiam à época (2006) 29 partidos registrados no TSE, dos quais 21 deles tinham representantes na Câmara e somente 7 superariam a cláusula de barreira. Oito partidos - PSDC, PTN, PRP, PSTU, PSL, PCB, PRTB, PCO - não lograram eleger Deputado Federal. Cf. voto do Min. Marco Aurélio. STF, Pleno, ADI N. 1.351, rel. Min. Marco Aurélio, 07.12.06, DJ 30.03.07.
} 
Outra significante perda consistiria na drástica redução do tempo de propaganda partidária na mídia:

Lei N. 9.096/95, art. 48: "O partido registrado no Tribunal Superior Eleitoral que não atenda ao disposto no art. 13 tem assegurada a realização de um programa em cadeia nacional, em cada semestre, com a duração de dois minutos.

Art. 49. O partido que atenda ao disposto no art. 13 tem assegurado:

I - a realização de um programa, em cadeia nacional e de um programa, em cadeia estadual em cada semestre, com a duração de vinte minutos cada;

II - a utilização do tempo total de quarenta minutos, por semestre, para inserções de trinta segundos ou um minuto, nas redes nacionais, e de igual tempo nas emissoras estaduais."

Enquanto os partidos de grande porte gozariam da plenitude dos recursos e de espaço de oitenta minutos por ano em cadeias nacional e estadual e os partidos excluídos deveriam se promover com apenas dois minutos. Sem recursos e sem tempo na mídia, 22 partidos estavam fadados à morte lenta. Isso porque, em tese, o partido não deixaria de existir. Não obstante, não teria atuação parlamentar, não se financiaria e não se divulgaria.

Às vésperas do pleito eleitoral de 2006, que ocorreu em 6 de outubro, o Tribunal Superior Eleitoral divulgou em seu portal na internet três possíveis interpretações para a nova regra o art. 13 da lei assinalada ${ }^{287}$. A não consolidação do entendimento antes do pleito causou insegurança aos partidos.

Pela primeira interpretação, o Tribunal considerou os partidos que haviam alcançado $5 \%$ dos votos válidos em todo o país, tomada a votação em todo território nacional, sendo que este percentual estaria obrigatoriamente distribuído no mínimo em nove Estados (um terço dos Estados), nos quais deveriam os partidos ter atingido o mínimo de $2 \%$. Os votos obtidos em um Estado que não atingir esse patamar de $2 \%$ não seriam computados para verificação da barreira de 5\%, sendo seus votos deduzidos do total obtido pelo partido ${ }^{288}$. Tal entendimento resultaria na superação da barreira por sete partidos: PMDB, PT, PSDB, PFL, PP, PSB e PDT ${ }^{289}$.

287 Folha de São Paulo, Folha on line, TSE define hoje aplicação da cláusula de barreira, São Paulo, 05.10.06, disponível (on line) in www1.folha.uol.com.br/folha/brasil/ult96u84756.shtml., [05.12.07]. Cf. também: G1, Agência Estado, TSE julga viável fusão partidária para superar cláusula, São Paulo, 05.10.06, disponível (on line) in g1.globo.com/Noticias/Politica/0,AA1300564-5601,00.html., [05.12.07].

${ }^{288}$ Os cálculos, conforme esta interpretação, que foi a adotada pelo STF (ADI N. 1.351), são realizados da seguinte forma: 1) Toma-se o total de votos nacionais válidos (93.184.830 - consideradas as eleições de 2006); 2) $5 \%$ da votação nacional equivale a 4.659 .242 votos. O primeiro corte se dá para os partidos que não totalizaram esse montante; 3) Esses 4,6 milhões de votos devem estar distribuídos, ao menos em 1/3 dos Estados e o partido deve obter pelo menos $2 \%$ do total de votos para Deputado Federal no (e do) respectivo Estado - somente dessa forma, seus votos serão computados no total nacional; nos Estados onde se alcance o 
De acordo com a segunda interpretação, seriam dez os partidos a atingir a meta. O cálculo empregado nessa versão considera que é necessário que o partido receba, além dos $5 \%$ do total de votos válidos em todo o país, ao menos $2 \%$ em nove Estados ${ }^{290}$.

E, conforme a terceira visão, somente seis partidos sobreviveriam (o PDT seria o partido excluído da lista conforme a primeira interpretação). Nesse rigoroso cálculo, apuraram-se 5\% dos votos válidos apenas nos nove Estados nos quais o partido obteve maior votação. Para cada um desses Estados, o partido deveria ter atingido ao menos $2 \%$ dos votos válidos ${ }^{291}$.

mínimo exigido, os votos obtidos não são computados: aquele Estado e seus votos "não contam" 4) Finalizase o cálculo verificando se a nova soma obtida atinge os $5 \%$ da cláusula de barreira. Fonte do número de votos: TSE.

${ }^{289}$ O PDT obteve 4,8 milhões de votos, correspondentes a 5,19\% dos votos válidos em todo país. Em seis Estados não logrou obter os $2 \%$ mínimos. Por isso, são excluídos 136.873 votos, soma desses seis Estados. No restante dos vinte e um Estados obteve mais de $2 \%$ dos votos, que então totalizaram aproximadamente 4,7 milhões, superior aos 4.659.242 de votos (5\% do total de votos válidos nacionalmente) exigidos pela cláusula de barreira.

${ }^{290}$ Ou seja, ao contrário da primeira interpretação, não se excluem do cômputo total para a verificação do limite de $5 \%$ os votos dos Estados que não atingiram o mínimo de $2 \%$. Basta haver no mínimo nove Estados que supram essa condição.

${ }^{291}$ Tomam-se nove Estados com a maior votação. Verifica-se se atingiram o mínimo de $2 \%$ em cada um e se sua soma iguala ou excede os $5 \%$ dos votos nacionais. 
Quadro 3: "O desempenho dos partidos em face da cláusula de barreira"292

\begin{tabular}{|c|c|c|c|c|}
\hline Partido & $\%$ votos & Número de votos & Deputados Eleitos & $\begin{array}{c}\text { Atingiu patamar de } \\
2 \% ?^{293}\end{array}$ \\
\hline PT & $\mathbf{1 4 , 9 4}$ & $\mathbf{1 3 . 9 8 9 . 8 5 9}$ & $\mathbf{8 3}$ & Sim \\
\hline PMDB & $\mathbf{1 4 , 5 1}$ & $\mathbf{1 3 . 5 8 0 . 5 1 7}$ & $\mathbf{8 9}$ & Sim \\
\hline PSDB & $\mathbf{1 3 , 7 6}$ & $\mathbf{1 2 . 8 8 3 . 1 4 7}$ & $\mathbf{6 6}$ & Sim \\
\hline PFL & $\mathbf{1 0 , 8 8}$ & $\mathbf{1 0 . 1 8 2 . 3 0 8}$ & $\mathbf{6 5}$ & Sim \\
\hline PP & $\mathbf{7 , 1 1}$ & $\mathbf{6 . 6 6 0 . 9 5 1}$ & $\mathbf{4 1}$ & Sim \\
\hline PSB & $\mathbf{6 , 2 1}$ & $\mathbf{5 . 8 1 3 . 4 9 4}$ & $\mathbf{2 7}$ & Sim \\
\hline PDT & $\mathbf{5 , 1 9}$ & $\mathbf{4 . 8 7 2 . 0 7 4}$ & $\mathbf{2 4}$ & Sim \\
\hline PTB & 4,72 & 4.416 .566 & 22 & Não \\
\hline PL & 4,53 & 4.074 .393 & 23 & Não \\
\hline PPS & 3,99 & 3.740 .005 & 22 & Não \\
\hline PV & 3,65 & 3.421 .007 & 13 & Não \\
\hline PC do B & 2,12 & 1.982 .323 & 13 & Sim \\
\hline PSC & 1,86 & 1.745 .132 & 9 & Não \\
\hline PSOL & 1,23 & 1.149 .619 & 3 & Não \\
\hline PRONA & 0,97 & 906.347 & 2 & Não \\
\hline PMN & 0,94 & 875.616 & 3 & Não \\
\hline PTC & 0,86 & 804.226 & 3 & Não \\
\hline PHS & 0,46 & 435.019 & 2 & Não \\
\hline PSDC & 0,38 & 355.021 & 0 & Não \\
\hline PT do B & 0,32 & 302.520 & 1 & Não \\
\hline PAN & 0,32 & 301.266 & 1 & Não \\
\hline PRB & 0,25 & 232.977 & 1 & Não \\
\hline PRP & 0,25 & 231.171 & 0 & Não \\
\hline PSL & 0,2 & 187.340 & 0 & Não \\
\hline PRTB & 0,18 & 170.436 & 0 & Não \\
\hline PTN & 0,16 & 151.292 & 0 & Não \\
\hline PSTU & 0,11 & 100.574 & 0 & Não \\
\hline PCB & 0,05 & 43.719 & 0 & Não \\
\hline PCO & 0,03 & 26.949 & 0 & Não \\
\hline
\end{tabular}

Alguns partidos, que geralmente não figuravam nas listas que os taxavam como legendas de aluguel, restariam excluídos do parlamento nacional, independentemente da interpretação adotada. Como exemplos, partidos com ideologias definidas, representantes de minorias ideológicas: o PV (Partido Verde), o PPS (Partido Popular Socialista) - que tem origem no histórico PCB - e o PSOL (Partido Socialismo e Liberdade).

O TSE então se pronunciou no sentido de que a Lei N. 9.096/95 autoriza fusões partidárias como forma de sobrevivência dos nanicos. $\mathrm{O}$ artifício foi usado de imediato pelo PTB, detentor de 4,7\% dos votos nacionais para Deputado Federal, portanto, abaixo da meta de barreira. O partido incorporou o PAN (Partido dos Aposentados

\footnotetext{
${ }^{292}$ Em destaque os partidos que superariam a cláusula de barreira. Dados das eleições 2006. Fonte: STF, Pleno, ADI N. 1.351, rel. Min. Marco Aurélio, 07.12.06, DJ 30.03.07.

${ }^{293}$ Patamar de $2 \%$ dos votos para Deputado Federal em no mínimo nove Estados. Foi considerado o cálculo da 'primeira interpretação'.
} 
Nacional, com $0,3 \%$ dos votos) em 5 de outubro de 2006. A operação permitiria ao PTB superar a barreira, qualquer que fosse a interpretação atribuída pelo TSE ao dispositivo legal.

\subsubsection{ADI N. 1.351 e ADI N. 1.354}

Nesse clima de confusão acerca da aplicação das regras de desempenho eleitoral sobre os resultados do pleito de outubro de 2006, ao final do mesmo ano, em 7 de dezembro, o Supremo Tribunal Federal julgou as ADI N. 1.351 e N. 1.354 conjuntamente.

A primeira fora proposta pelo PC do B, PDT e PV. A segunda pelo PSC, admitidos como terceiros o PPS e o PSOL. Ambas atacavam a incompatibilidade com o texto constitucional do disposto no art. 13 da Lei N. 9.096/95 e demais remissões, contidas nos artigos 41, 48, 49, 56 e 57.

Somente por ocasião do julgamento no STF é que se obteria o entendimento das Cortes Judiciárias sobre o instituto da cláusula de exclusão, em especial sobre a fórmula de calculá-la. A interpretação foi dada pelo próprio Presidente do TSE e Ministro do STF, Ministro Marco Aurélio, quando de seu voto como relator da ADI N. 1.351. O Ministro ditaria os comandos de forma similar à primeira interpretação acima aludida ${ }^{294}$, assim expressando seu entendimento:

\footnotetext{
"Vê-se que o artigo 13 em questão, relativamente ao funcionamento parlamentar nas Casas Legislativas, prevê que o partido político deve preencher dois requisitos. $\mathrm{O}$ primeiro deles refere-se à quantidade dos votos válidos atinentes às cadeiras da Câmara dos Deputados. Então, há de se ter o mínimo de cinco por cento da totalidade dos votos apurados, não computados os brancos e os nulos. Atendida essa condição, surge novo obstáculo a ser ultrapassado. É preciso que os cinco por cento dos votos estejam distribuídos em nove Unidades da Federação, exigida ainda a quantidade mínima de dois por cento em cada uma delas. Eis, então, os pressupostos para que o partido político, em verdadeira corrida de obstáculos, alcance o funcionamento parlamentar:

a) Obtenção de cinco por cento dos votos válidos para a Câmara dos Deputados, considerada a votação em todo o território nacional, afastados os brancos e nulos;

b) Distribuição desse percentual mínimo, em pelo menos um terço dos Estados brasileiros;

c) Conquista, em cada um dos nove Estados, da porcentagem mínima de dois por cento." 295 (grifos nossos)
}

${ }^{294}$ V. Nota N. 288 deste capítulo.

${ }^{295}$ STF, Pleno, ADI N. 1.351, rel. Min. Marco Aurélio, 07.12.06, DJ 30.03.07. Note-se que, no trecho em destaque, o Ministro afirma que os 5\% dos votos devem estar distribuídos em nove (nem mais, nem menos) Estados. Isso é substancialmente diferente de se dizer "Distribuição desse percentual mínimo (5\%), em pelo

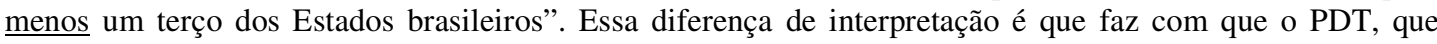


Fixada a interpretação ao art. 13 da Lei dos Partidos Políticos, o Ministro Marco Aurélio tratou de expor os fundamentos constitucionais que, no seu entendimento, chocavam-se frontalmente com o dispositivo criado pelo legislador ordinário. Considerou que a Lei N. 9.096/95 atentou à medular liberdade conferida aos partidos, na criação, na incorporação, fusão e extinção dessas pessoas jurídicas de direito privado. Igualmente, afrontou o pluralismo político e o pluripartidarismo constantes, respectivamente, do art. $1^{\circ}$., V e da cabeça do art. 17, CF/88, trazidos como fundamento da República brasileira.

Conforme lembrou o Ministro Gilmar Mendes, em acréscimo ao rol de princípios citado pelo Ministro Marco Aurélio, deve-se considerar o principio da isonomia, que impede a existência de duas classes de partidos, sendo uma delas priorizada com a grande fatia dos recursos e a outra tendo diminuído, além de recursos financeiros, o acesso à propaganda partidária - fatores que asseguram a igualdade de condições na disputa eleitoral. Conclui o Ministro não restar dúvida “de que a 'igualdade de chances’ é princípio integrante da ordem constitucional brasileira" ${ }^{296}$. Impedida a livre concorrência entre os partidos, prejudicados ficam os modelos democrático e representativo.

Além da igualdade, o texto constitucional busca a proteção das minorias, a existência de partidos de oposição, a representação de todas as correntes de pensamento e ideologias que refletem o amplo espectro de opiniões da sociedade civil. Nas palavras do Ministro Marco Aurélio, ao criar duas classes distintas de partidos políticos, "as previsões constitucionais encerram a neutralização da ditadura da maioria, afastando do cenário nacional óptica hegemônica e, portanto, totalitária" ${ }^{297}$. Com esse argumento, o relator descartou o entendimento de que o art. 17, V da Constituição Federal remete ao legislador ordinário tratar do funcionamento parlamentar. Para o Ministro, a edição da Lei de 1995 esvaziara os princípios constitucionais que dão suporte ao pluripartidarismo e afastara a soberania popular, uma vez que a vontade dos cidadãos seria desrespeitada. Os eleitores que sufragaram partidos de menor porte, que não obteriam a devida representatividade

superou os $5 \%$ de votos nacionais somente ao se considerar os 21 Estados onde atingiu o mínimo de $2 \%$, supere a barreira, se adotada uma interpretação ou reste excluído, conforme o outro entendimento.

${ }_{296}$ O Ministro Gilmar Mendes trouxe a concepção de HERMAN HELLER, autor alemão contemporâneo a Carl Schmitt, para quem "o Estado Democrático atual encontra seu fundamento, principalmente, na liberdade e igualdade da propaganda política, devendo assegurar-se a todas as agremiações e partidos igual possibilidade jurídica de lutar pela prevalência de suas idéias e interesses”. O princípio da igualdade de chances foi também considerado por G. LIEBHÖLZ como inerente ao modelo constitucional democrático. H. HELLER, Europa und der Faschismus, Berlin-Leipzig, 1929, p. 95 e ss.; G. LIEBHÖLZ, Verfassungsrechtliche Stelling und innere Ordnung der Parteien, APUD voto Min. Gilmar Mendes in STF, Pleno, ADI N. 1.351, rel. Min. Marco Aurélio, 07.12.06, DJ 30.03.07.

${ }^{297}$ STF, Pleno, ADI N. 1.351, rel. Min. Marco Aurélio, 07.12.06, DJ 30.03.07. 
parlamentar por um artifício da legislação, sentir-se-iam traídos, com a sensação de que seus votos foram injustamente excluídos. A redução do excessivo número de partidos se daria, de acordo com o Ministro, pelas urnas e pelo quociente eleitoral, que por si só, já cria uma barreira aos partidos menos votados.

Relativamente aos direitos das minorias, crucial rememorar-se a lição de MANOEL GonÇALVES FERREIRA FilHo, ressaltando os caracteres essenciais de um regime democrático:

"Afirmação da liberdade de cada um e da liberdade de todos, a Democracia implica para cada um e para todos a autodeterminação (...). Não pode suportar que uma maioria, em momento talvez de ilusão ou embriaguez, sacrifique a sua liberdade e a da minoria para sempre, como ninguém admite que um homem se dê como escravo. (...). A Democracia não pode suportar que um grupo, sob a proteção das leis, lhe solape as bases." 298

A maioria parlamentar é quem faz a lei e foi exatamente via legislação ordinária - que a maioria dos Deputados empregou tal ardil para reduzir à míngua a atuação das minorias, além de criar situações esdrúxulas ${ }^{299}$, distanciando-se da razoabilidade, de acordo com o Ministro Marco Aurélio. Eventuais desvios de finalidade na utilização das máquinas partidárias "hão de ser combatidos de forma razoável, sem a colocação em segundo plano de valores inerentes à democracia, a um Estado Democrático de Direito". Neste, as maiorias definem o bem-estar público, sem que lhes seja dado o direito de restringir "as liberdades fundamentais dos grupos minoritários", dentre as quais está a liberdade de se fazer representar e "participar da vida pública, inclusive fiscalizando os atos determinados pela maioria" 300 .

A eliminação das agremiações minoritárias traria outro agravante: a "fusão das heterogeneidades", segundo o Ministro Gilmar Mendes. O Ministro questiona qual será o destino dos Deputados ligados a fortes ideologias, tais como as ambientalistas do Partido Verde ou as socialistas e comunistas características de outras legendas. A fusão

\footnotetext{
${ }^{298}$ M. G. FERREIRA FILHO, Os partidos políticos nas constituições democráticas, cit., p 60.

299 O Min. relator Marco Aurélio cita os exemplos do Presidente da Câmara Aldo Rebelo e do VicePresidente da República, respectivamente filiados ao PC do B e PRB, que não lograriam superar os $5 \%$ para terem garantida sua representação parlamentar. Em situação não menos desconfortável estaria o PTB, que com mais de seis milhões de votos, faltariam-lhe $0,3 \%$ para superar a barreira dos $5 \%$ de votos nacionais e com isso teria reduzida em $99,4 \%$ suas verbas do Fundo Partidário. Igualmente a diminuição de seu tempo de propaganda partidária levaria a uma migração em massa para outras legendas. STF, Pleno, ADI N. 1.351, rel. Min. Marco Aurélio, 07.12.06, DJ 30.03.07.

${ }^{300}$ O Ministro Marco Aurélio frisou ainda que: “A Democracia não é a ditadura da maioria!”. STF, Pleno, ADI N. 1.351, rel. Min. Marco Aurélio, 07.12.06, DJ 30.03.07.
} 
como último recurso de sobrevivência seria tão maléfica ao sistema quanto à atomização, de acordo com o Ministro Sepúlveda Pertence.

Diante de todo o exposto, por unanimidade, o STF julgou procedente a ação direita para declarar inconstitucionais os seguintes dispositivos que criavam a cláusula de barreira: art. 13; a expressão “obedecendo aos seguintes critérios”, encontrada na cabeça do art. 41, bem como seus incisos; o art. 48; a expressão "que atenda ao disposto no art. 13”, presente no art. 49; o caput dos arts. 56 e 57, com interpretação que elimina as limitações temporais neles constantes, de modo a prevalecer o texto original até que sobrevenha nova disposição legislativa a respeito ${ }^{301}$; e a expressão "no art. 13", contida no inciso II do art. 57, da Lei N. 9.096/95.

Não obstante ter a Corte Suprema julgado inconstitucionais os dispositivos referentes ao mecanismo da cláusula de barreira, a excluir a grande maioria dos pequenos partidos, a cláusula de barreira não é incompatível com o ordenamento brasileiro $^{302}$. A inconstitucionalidade do dispositivo legal residiria exatamente no desrespeito aos princípios constitucionais supracitados, principalmente aqueles que visam à preservação da diversidade essencial à democracia, bem como ao estabelecido no $\S 1^{\circ}$. do art. 58 da Carta Maior ${ }^{303}$. A cláusula de barreira "à brasileira" (termos do Ministro Gilmar Mendes) representa um retrocesso, pois "acentua as deformidades de nosso singular sistema eleitoral proporcional" 304.

${ }^{301}$ O legislador atuou de forma a regulamentar a distribuição do Fundo Partidário após a decisão do STF, inserindo o art. 41-A na Lei dos Partidos, com a seguinte redação: "5\% (cinco por cento) do total do Fundo Partidário serão destacados para entrega, em partes iguais, a todos os partidos que tenham seus estatutos registrados no Tribunal Superior Eleitoral e 95\% (noventa e cinco por cento) do total do Fundo Partidário serão distribuídos a eles na proporção dos votos obtidos na última eleição geral para a Câmara dos Deputados." (Incluído pela Lei N. 11.459, de 2007). Com o advento da minirreforma eleitoral, vários foram os preceitos referentes à distribuição de recursos e de tempo de propaganda eleitoral alterados. V. Lei N. 12.034 de 29 de setembro de 2009.

${ }^{302}$ De acordo com o Ministro Gilmar Mendes, na leitura dos arts. 27, § $1^{\circ}$.e 45 da CF/88, fica claro que "o legislador dispõe de alguma discricionariedade na concretização do sistema proporcional". STF, Pleno, ADI N. 1.351, rel. Min. Marco Aurélio, 07.12.06, DJ 30.03.07.

${ }^{303} \mathrm{O}$ dispositivo em destaque prevê que a Mesa Diretora da Casa e as comissões devem ser integradas, de forma proporcional, pelos partidos lá representados.

${ }^{304}$ Segundo o Ministro Gilmar Mendes, não reside dúvida sobre "a inconstitucionalidade dessa 'cláusula de barreira à brasileira"”. Todavia, crê ser "possível, sim, ao legislador pátrio, o estabelecimento de uma cláusula de barreira (...)”. Mas não do modo que fez, pois, continua o Ministro, “(...) se o legislador brasileiro tivesse conformado um modelo semelhante ao adotado no direito alemão, (...), talvez não estaríamos aqui a discutir esse tema". O modelo brasileiro "não deixou qualquer espaço para a atuação partidária, mas simplesmente negou, in totum, o funcionamento parlamentar (...), numa clara violação ao princípio da proporcionalidade”. STF, Pleno, ADI N. 1.351, rel. Min. Marco Aurélio, 07.12.06, DJ 30.03.07. No sistema eleitoral alemão, que adota o voto distrital misto, somente terá representação no Parlamento Nacional ou nos regionais, o partido que obtiver no mínimo 5\% dos votos no total nacional ou tiver eleito pelo menos três Deputados Distritais. 
Parece ter o legislador errado no quantum, desconsiderando a realidade nacional e exagerado ao simplesmente vedar o funcionamento parlamentar. Tivesse sido moderado em relação aos percentuais exigidos e quanto às consequências que levaram à desigualdade (exaurimento dos recursos e do tempo de propaganda), ao invés de repetir o texto de Cartas anteriores, poderia ter, quiçá, criado cláusula de barreira respeitando-se os princípios da autonomia partidária, do pluralismo político e do pluripartidarismo, visando eliminar as legendas de aluguel e evitando possíveis migrações em massa para as legendas “fortes”, fato que abalaria qualquer construção em prol da fidelidade partidária.

\subsubsection{PEC N. 322/09}

O Supremo, ao decidir as ADI N. 1.351 e N. 1.354, manteve vigentes as disposições transitórias, que mitigam a cláusula de barreira. A decisão unânime alertou que a provisoriedade prevaleceria até que o legislador atuasse. Desde então, surgiram algumas propostas para nova regulamentação. Entre elas, encontra-se a PEC N. 322/09, que viria dentro de um pacote da reforma política proposta pelo governo ${ }^{305}$. A estratégia do governo consistia em aprovar separadamente cada um dos pontos da reforma política, pois, as tentativas pretéritas de se aprovar um grande pacote de reformas não vingaram, uma vez que a existência de qualquer ponto polêmico impedia a votação e relegava a reforma a um futuro incerto.

A PEC N. 332/09 propõe a alteração do art. 17 da Constituição, visando a introdução de cláusula de desempenho eleitoral. Propondo que as mudanças tenham efeito somente a partir do processo eleitoral do ano de 2010, acresce um parágrafo ao citado artigo:

$\S 5^{\circ}$. "Somente exercerão mandato de deputado federal, deputado estadual ou deputado distrital candidatos de partidos que obtiverem um por cento dos votos válidos, excluídos os brancos e os nulos, obtidos em eleição geral para a Câmara dos Deputados, distribuídos em, pelo menos, um terço dos Estados, com o mínimo de meio por cento dos votos em cada um deles."

A proposta era vista por alguns parlamentares como a de maior prioridade para o ano que entrava. Chegou-se a cogitar de incluí-la na minirreforma

${ }^{305}$ Rádio Câmara, Sílvia Mugnatto, Proposta do governo para reforma política traz inovações, 13.02.09, Brasília, disponível (on line) in http://www2.camara.gov.br/internet/radio/chamadaExterna.html?link= http://www.camara.gov.br/internet/radiocamara/default.asp?selecao=MAT\&Materia=79864., [21.02.09]. 
eleitoral, que, todavia, decepcionou a muitos com seu conteúdo, ao deixar de propor soluções efetivas para os principais problemas políticos. A indigitada minirreforma eleitoral alterou basicamente questões relativas à distribuição do Fundo Partidário e da propaganda eleitoral, regulamentando o uso da internet. A PEC contendo a modelagem da nova cláusula de barreira não teve seu seguimento na tramitação das Casas Legislativas até o últimos meses do ano de 2009, sinalizando que, por mais uma vez, a esperada reforma não virá, abrindo campo para que as regras definidas pela Corte Suprema continuem em vigor, enquanto o legislador não atua.

\subsubsection{Nanicos ou oligarquias? As reais mazelas do sistema partidário}

M. HeRman SALEM CAGgiano mostra que é lugar comum afirmar que a técnica de divisão das cadeiras parlamentares influencia o sistema partidário. Igualmente pode-se dizer da percepção de que os sistemas eleitorais atuam sobre o sistema de partidos. Mas a autora observa contundentemente que, tudo que atinja a representação política, seja um fator de desempenho mal regulado, sejam sistemas eleitorais mal elaborados, contamina diretamente a democracia ${ }^{306}$. E, nesse sentido, perceberemos a premência da reforma política no país e a ineficácia de paliativos, que pretendem antes vendar os olhos para os problemas reais e remediar os efeitos indesejados a eliminar o mal pela raiz.

M.G. FERREIRA FILHO descreve o caráter ambivalente dos partidos. De um lado, são necessários ou convenientes, por sua incumbência de apresentar ao eleitorado as opções políticas existentes. De outro, agindo de forma desvirtuada pelo "domínio oligárquico, pela corrupção financeira, pela indisciplina”, são verdadeiras “máquinas para a conquista do poder", constituindo-se em reais instrumentos de "destruição da democracia"307. A percepção cotidiana deixa o sentimento de que os partidos não são nada além do que um "mal necessário". Indo mais além, não seria tão arriscado dizer que a candidatura avulsa lograria sucesso, ao menos no sentido de preenchimento das vagas, dado o personalismo entre nós instaurado. A sensação passa a ser que essas instituições, no atual quadro político pátrio, apresentam-se totalmente desvirtuadas dos seus reais

\footnotetext{
306 M. Herman Salem Caggiano, Sistemas Eleitoras $x$ Representação Política, Tese de Doutorado apresentada à Faculdade de Direito da Universidade de São Paulo, 1987, p. 181-188.

${ }^{307}$ M. G. FERREIRA FILHO, Curso de Direito Constitucional, cit., p. 124.
} 
propósitos. Tudo isso se deve aos vícios do sistema partidário, como bem aponta M.G. FERREIRA FILHO, resumindo-os em três tópicos: a inautenticidade dos partidos brasileiros, o individualismo brasileiro e o número excessivo de partidos.

Referente ao primeiro item tem-se que a autenticidade dos partidos é uma das condicionantes da democracia descritas pelo autor. A ideologia e o programa partidário que dão consistência a essa autenticidade raramente estão presentes no quadro partidário nacional, fazendo com que os partidos não passem de "conglomerados decorrentes de exigências eleitorais". Os partidos são "vazios, como corpos sem alma", proclama o ilustre professor. De um lado, o desapreço pela construção de programas definidos. A generalidade e abstração são marcas dos ditos programas partidários, "que ninguém leva a sério", nos termos do mestre ${ }^{308}$. De outro, a falta de autenticidade está intimamente conectada com a cultura marcada pela falta de inclinação à vida cívica, requisito necessário para uma democracia verdadeira. Paralelamente, apresenta-se a cultura individualista e oportunista do brasileiro, negando qualquer forma de associativismo e cooperação, colocando o interesse particular acima do geral.

Por fim, frisa M.G. FerReIRA FILHO a tendência à multiplicação do número de legendas, com funestas implicações, dentre as quais a dificuldade de governabilidade do país é uma das mais graves. Aponta o autor o sistema eleitoral proporcional como um de seus vilões. Em sua visão, "a fórmula da democracia pelos partidos não se compatibiliza com o funcionamento de um número muito grande de partidos",309.

Por sua vez, em opinião oposta a M.G. FERREIRA FILHO, Luís VirGílio AFONSO DA SILVA, afirma não ser correto proclamar que o sistema eleitoral determina a estrutura partidária, bem como concluir que o sistema majoritário é causa ou condição para o bipartidarismo ou ainda que o sistema proporcional leve sempre ao multipartidarismo, por mais que a observação geral leve a essa conclusão. Isso porque os sistemas eleitorais não são o único fator de influência sobre o sistema de partidos, mas, de fato, propagam seus efeitos políticos nos sistemas partidários. Entre eles, o autor aponta a estabilidade e a

\footnotetext{
${ }^{308}$ Para o autor, "a política brasileira é uma disputa personalista; vale mais o candidato que o partido". Cf. M. G. FERREIRA FILHO, Curso de Direito Constitucional, cit., p. 127-8.

${ }^{309} \mathrm{O}$ autor procura demonstrar que a experiência mundial condena o "multipartidarismo excessivo". Propõe que o Estado de Partidos reclama o bipartidarismo idealmente, no qual o povo "escolhe quem vai governar e qual a orientação do governo". Ao contrário, o multipartidarismo apresenta a necessidade de acordo entre partidos para constituir a coalizão majoritária, que, na tentativa de maior governabilidade fixa o programa de governo "à margem da vontade popular", diz o autor. M. G. FerReIRA FilHo, Curso de Direito Constitucional, cit., p. 128.
} 
governabilidade, como mais propensas a ocorrer em sistemas majoritários e, de outro lado, a representatividade, como efeito mais presente em sistemas proporcionais.

Nos sistemas proporcionais, via de regra - e o brasileiro é apontado como rara exceção - o voto se dá em partidos, tendo por consequência o fortalecimento do papel desses e a delineação ideológica do voto. Assim, tem-se a despersonalização do voto, ou seja, o eleitor vota no programa, na ideologia e não por simpatia pessoal ${ }^{310}$.

A experiência colhida das eleições brasileiras dos últimos vinte anos mostra porque se fala em exceção. De fato, muitos eleitos são personagens da mídia: cantores, apresentadores de programas de televisão, esportistas, mostrando não só o poder da mídia, como também o descolamento do eleitor quanto ao conteúdo programático ou ideológico que o representante acompanha ${ }^{311}$. Em uma verdadeira democracia, como aponta L. VIRGÍlio AFONSO DA SilvA, a despersonalização proporciona maior sinceridade e conteúdo aos programas de governo dos partidos, fazendo com que os verdadeiros se fortaleçam e os de aluguel desapareçam. Não parece ser nosso caso. A personalização existente enfraquece os partidos a ponto de pouco significarem - apenas um amontoado de siglas das quais o cidadão brasileiro não se importa em saber o significado. Sinal, aliás, do verdadeiro enfraquecimento das legendas - o que implica outra maior patologia do sistema partidário: a oligarquização, isto é, o controle político na mão de pequenos grupos de poder, ou os chamados caciques políticos, donos das legendas. O partido político se torna instrumento de poder das oligarquias quanto menor a participação ativa do brasileiro na vida partidária $^{312}$.

Deste modo, o sistema deforma-se completamente ao perder a verdadeira qualificação política do processo deliberativo - no sentido essencial do termo "política", aquele que envolve toda a comunidade. O que se observa, por conseguinte, é uma colonização e degeneração dos partidos políticos brasileiros.

\footnotetext{
${ }^{310}$ L. VIRGílio AfONSO DA SiLVA, Sistemas Eleitorais - Tipos, efeitos jurídico-políticos e aplicação ao caso brasileiro, São Paulo, Malheiros, 1999, p. 138.

311 Cf. L. Virgílio AfOnSo DA Silva, "é notória a idéia de que os partidos políticos brasileiros pouco ou nada significam. (...) não faz diferença o partido pelo qual se candidatam”. Sistemas Eleitorais - Tipos, efeitos jurídico-políticos e aplicação ao caso brasileiro, cit., p. 160-161. Para M. G. FERREIRA FILHO, "o elemento pessoal continua a pesar e não raro a preponderar. Mormente hoje, quando os meios audiovisuais de comunicação de massa valorizam as personalidades em detrimento das idéias." Curso de Direito Constitucional, cit., p. 128.

${ }^{312}$ M. G. FerreIRA Filho, Curso de Direito Constitucional, cit., p. 127-128. No ensinamento do douto professor, "Esses políticos, por assenhorarem-se da máquina partidária, poderão ao seu bel-prazer e segundo os seus interesses, raramente coincidentes com o interesse comum, escolher candidatos, predeterminando forçosamente a escolha popular, (...)".
} 
Agravando o quadro já deteriorado, a individualização das campanhas leva à disputa intrapartidária ${ }^{313}$, enfraquecendo ainda mais os partidos ${ }^{314}$. Mais do que uma máquina organizadora dos eleitores, o partido se transforma no meio de conquista do poder por meio da captação de votos, não importando a ideologia que pretensamente se defenda, tão pouco seu conteúdo programático ${ }^{315}$. Desse fato, também, exsurge a facilidade da troca de legendas, pois, se não identificado ideologicamente com o partido originário, não há de se falar em mudança de ideologia quando da troca de legenda.

Majoram-se os efeitos dessa tradição personalista, segundo L. VIRGílıIO AFONSO DA SILVA, com a adoção de listas não-hierarquizadas, com o voto nominal ${ }^{316}$. Sem a necessária reforma nesse sentido, as candidaturas continuarão personalizadas e os programas partidários relegados e desconhecidos pelo eleitor. A influência do poder econômico, como sendo um fator decisivo do sucesso e o alto custo das campanhas eleitorais, devido à necessidade de exposição na mídia, contribui também para o fenômeno da personalização.

Para o autor, a existência de brechas legislativas permite também a propagação de outras mazelas no sistema, tais como o próprio número excessivo de partidos, que de certa forma, influencia também na possibilidade ou facilidade de troca de legendas. Como exemplo das citadas brechas, tem-se a permissão legislativa à coligação de partidos para o registro comum de candidatos ${ }^{317}$, de forma que esses possam se beneficiar da contagem de votos como se fossem apenas um partido. Naturalmente, os "nanicos" que não obteriam representatividade por não atingir o quociente eleitoral, passam a ter nova chance de conseguir vagas.

\footnotetext{
${ }^{313}$ Com a falta de coesão e unidade partidária, o candidato não deve seu sucesso eleitoral apenas ao partido, pois precisa se distinguir dos outros candidatos do mesmo partido. Com uma campanha individualizada, buscará seu curral eleitoral e se comprometerá com seu grupo de interesses, fugindo aos do partido, criando ainda mais uma brecha para a infidelidade. Disso pode se inferir, que abalado fica o argumento de que o candidato se elege com os votos do partido, pois sem este não seria eleito. Esse fato se deve mais à forma de cálculo dos votos, do que à fortaleza da legenda perante o eleitorado.

${ }^{314}$ L. VIRGílio AFONSO DA SiLVA, Sistemas Eleitorais - Tipos, efeitos jurídico-políticos e aplicação ao caso brasileiro, cit., p. 160-161.

${ }^{315}$ L. VIRGílio AFONSO DA SILVA empresta de Otto Kirchheimer a expressão "catch-all parties”, que retratam bem o desempenho dos partidos brasileiros, que buscam a qualquer custo o bom desempenho nas urnas, na busca da conquista do poder, generalizando e flexibilizando suas ideologias e seus programas. Cf. L. VIRGílio AfONSO DA SILVA, Sistemas Eleitorais - Tipos, efeitos jurídico-políticos e aplicação ao caso brasileiro, cit., p. 161. Disso também, extrai-se o questionamento quanto à relevância do argumento de que o voto é concedido, no Brasil, a um programa político partidário.

${ }^{316}$ L. VIRGílio AfONSO DA Silva, Sistemas Eleitorais - Tipos, efeitos jurídico-políticos e aplicação ao caso brasileiro, cit., p. 162.

${ }^{317}$ Cf. art. 105, Código Eleitoral Brasileiro. Lei 4.737 de 15 de julho de 1965.
} 
Em vertente semelhante se observa o problema da formação das bancadas corporativas, conforme trazido por L. ViRgílio Afonso DA Silva, ao se referir aos congressistas pátrios, afirmando que: “(...) independente dos partidos a que pertençam e, consequentemente, do programa partidário que deveriam defender, pautam suas decisões apenas e tão somente por princípios corporativos, (...) ${ }^{318 ، .}$. O que nos leva crer que, ainda que proibida a troca de partido, a bancada corporativa, como denomina o autor, continuará a existir.

Portanto, a importância do estudo das patologias de nosso sistema, como resumidamente se apresentou acima, aparece exatamente quando se pensa em reforma política. Não se pretende neste estudo discorrer detalhadamente sobre as propostas de reformulação do sistema. Não obstante, não se pode atribuir as falhas presenciadas em nosso sistema a fatores outros, como à infidelidade partidária - como observaremos quando da análise dos votos proferidos sobre a questão - sem analisar as reais causas que levam à lastimável situação presenciada do sistema político nacional.

\subsection{A atividade interpretativa e normativa em matéria eleitoral}

A atividade interpretativa se perfaz pelo desenvolvimento de procedimentos que visam revelar o conteúdo e o alcance das normas que integram o ordenamento jurídico. A interpretação constitucional busca a concretização da Carta Maior por meio da compreensão de suas normas.

KONRAD HESSE apresenta uma limitação básica para o campo de atuação da interpretação constitucional valiosa para o presente estudo. Diz o autor alemão que a atividade interpretativa constitucional se faz premente quando se está diante de "uma questão constitucional que a Constituição não nos permite responder de modo conclusivo". O objetivo dessa atividade é obter um "resultado constitucionalmente 'correto' através de um procedimento racional e controlável" cuja fundamentação cria "certeza e previsibilidade jurídicas, ao invés de acaso, de simples decisão por decisão"319. Já para

\footnotetext{
${ }^{318}$ L. Virgílio AfONSO DA SiLVA, Sistemas Eleitorais - Tipos, efeitos jurídico-políticos e aplicação ao caso brasileiro, cit., p. 167.

${ }^{319}$ K. HeSSE, A interpretação constitucional, trad. Inocêncio Martirez Coelho in Temas fundamentais do Direito Constitucional, (org). Carlos S. Almeida, Gilmar F. Mendes e Inocêncio M. Coelho, Saraiva, São Paulo, 2009, p. 101-102.
} 
JORGE MIRANDA, “há sempre que interpretar a Constituição”, pois “só através dela, a partir da letra, mas sem parar na letra, se encontra a norma ou o sentido da norma." 320

Segundo EROS RoBerto GRAU, a interpretação do direito é responsável por sua inserção na realidade. A aproximação do direito com o mundo dos fatos se opera uma vez que

“(...) a interpretação do direito tem caráter constitutivo - não, pois, meramente declaratório - e consiste na produção, pelo intérprete, a partir de textos normativos e dos fatos atinentes a um determinado caso, de normas jurídicas a serem ponderadas para a solução desse caso, mediante a definição de uma norma de decisão." 321

Quanto ao procedimento hermenêutico, o Ministro Eros Grau professa:

\begin{abstract}
“A interpretação do direito, enquanto operação de caráter linguístico, consiste em um processo intelectivo através do qual, partindo de fórmulas linguísticas contidas nos atos normativos, alcançamos a determinação de seu conteúdo normativo; dizendo-o de outro modo, caminhamos dos significantes (ou enunciados) aos significados." 322
\end{abstract}

Foi possível observar nos quatro temas eleitorais abordados neste capítulo a intensa atividade exegética tanto do Tribunal Superior Eleitoral quanto da Suprema Corte, que, em várias oportunidades se manifestaram sobre cada um dos tópicos examinados, sempre fazendo largo uso da ferramenta da interpretação jurídica, que ora se aplicou sobre o texto da Norma Magna, ora sobre a legislação infraconstitucional. O resultado, como se apontou, foi a inflexão no entendimento de diversas questões eleitorais ao longo de pouco mais de duas décadas de vigência da Constituição de 1988.

Acima de tudo, foram a ânsia de resolver as mazelas políticas do país em vista de um Legislativo inoperante - e a maneira como se aplicou a hermenêutica jurídica, os fatos que mais alarmaram a academia, pois refletiram um intenso ativismo judicial. Noticiou-se por diversas vezes que o Judiciário estaria fazendo as vezes do Legislativo. Embates entre Presidentes das Casas do Congresso e dos Tribunais foram manchetes dos jornais que estampavam a "usurpação" do poder legislativo pelos $\operatorname{magistrados}^{323}$.

${ }^{320}$ J. Miranda, Teoria do Estado e da Constituição, Rio de Janeiro, Forense, 2002, p. 448.

${ }^{321}$ E. R. GRAU, A ordem econômica na Constituição de 1988, 9a. ed., São Paulo, Malheiros, 2004, p. 147.

${ }^{322}$ Cf. voto Min. Eros Grau in STF, Pleno, ADI N. 3.685, rel. Min. Ellen Gracie, 22.03.06, DJ 10.08.06.

323 V. e.g., Revista Jus Vigilantibus, Luiz Guilherme Marques, Judiciário x Legislativo?, São Paulo, 13.01.09, disponível (on line) in http://jusvi.com/colunas/37913., [21.02.09]; O Estado de S. Paulo, Denise Madueño, Chinaglia desafia TSE e diz que não cassará deputado infiel, 17.12.08, disponível (on line) in http://www.estadao.com.br/nacional/not_nac295284,0.htm., [21.02.09]. 
Radical ou não o posicionamento da mídia, na verdade, reflete uma percepção de mudança no entendimento que a Corte Suprema vinha adotando historicamente com relação à hermenêutica constitucional. Por detrás dessa suposta retificação dos rumos hermenêuticos está a tese do neoconstitucionalismo ${ }^{324}$ ou póspositivismo, como denomina um de seus expoentes, Luís ROBERTO BARROSO ${ }^{325}$. Esse é o motivo que nos leva a rever os fundamentos dessa teoria, passando pela comparação com a tese a que se contrapõe, a tradicional, ou, nos termos do autor, a tese de interpretação constitucional conservadora. Mais adiante, ainda neste tópico, será demonstrado como atuaram as Cortes relativamente às quatro decisões em exame.

Não se pretende no presente estudo abrir um amplo debate sobre as diferentes posições a respeito da interpretação constitucional, muito menos chegar-se a uma verdade absoluta. Mais prudente será apresentar os ensinamentos de cada corrente, visando trazer elementos para embasar a análise crítica dos votos proferidos nas recentes decisões referentes à matéria eleitoral.

O tema da interpretação constitucional continua em pauta na doutrina atual. Assim encontramos em L. Virgílio AfOnSo DA Silva a afirmação de que a discussão mais urgente diz respeito ao papel do STF no exercício da atividade interpretativa constitucional. Caberia ao Supremo fazer valer determinados valores constitucionais? Ou estaria reservado ao legislador decidir sobre eles? ${ }^{326}$ São questões colocadas pelo o autor que permeiam os debates que envolvem as recentes decisões tomadas pelo Supremo e pela Corte Eleitoral, das quais as principais são objetos de exame neste trabalho. Para o deslinde dessas indagações, ainda que não se encontrem respostas definitivas, importante se faz revisitar brevemente as teorias que fornecem o pano de fundo deste intenso debate.

\footnotetext{
${ }^{324}$ ELIVAL DA SILVA RAMOS aponta no plano da dogmática o neoconstitucionalismo, dentre as razões que implusionam o ativismo judicial no Brasil. Cf. Parâmetros dogmáticos do ativismo judicial em matéria constitucional, Tese de Titularidade apresentada à Faculdade de Direito da Universidade de São Paulo, 2009, p. 264.

${ }^{325}$ L. R. BARroso, Interpretação e Aplicação da Constituição, São Paulo, Saraiva, 2007, p. 103-386.

${ }^{326}$ L. VIRGÍlio AFONSO DA SILVA, Interpretação constitucional e sincretismo metodológico, in L. VIRGÍliO AFONSO DA SILVA (org.) Interpretação constitucional, São Paulo, Malheiros, 2005, p. 143.
} 


\subsubsection{Hermenêutica e neoconstitucionalismo}

O pensamento filosófico da corrente jusnaturalista, desenvolvida a partir do século XVI, colocou a lei em posição superior no Direito e fundou-se em princípios de justiça natural, universalmente válidos. A antítese veio com o positivismo jurídico, que, no fim do século XIX, fundado na objetividade do direito posto, equiparou o direito à lei, afastando discussões filosóficas. Abalou-se o positivismo diante do nazismo e fascismo e do horror das guerras, quando veio a ser superado por "um conjunto amplo e ainda inacabado de reflexões acerca do Direito, sua função social, e sua interpretação" ${ }^{327}$. ELIVAL DA SILVA RAMOS reconhece que "as inconsistências e lacunas do positivismo em matéria de interpretação normativa" motivaram pesadas críticas "desfechadas pelo moralismo jurídico", que pretende "a coincidência entre o direito e a moral", com base na exacerbação da aplicação dos princípios constitucionais ${ }^{328}$.

Esse leque de novas idéias tem recebido diversas denominações. Com a retomada da importância da Constituição, falou-se em "reconstitucionalismo". L. R. BARRoso, por sua vez, rotula esse rol de novos pensamentos de "pós-positivismo", caracterizado por "ir além da legalidade estrita", mas que - importante a transcrição da ressalva - "não despreza o direito posto". ${ }^{329}$ Entre as propostas pós-positivistas, tem-se a sugestão de uma nova fonte de inspiração para a interpretação e aplicação do ordenamento jurídico - uma teoria de justiça - que, não obstante, alerta o autor, "não podem comportar voluntarismos ou personalismos, sobretudo os judiciais" (grifos nossos). ${ }^{330}$ L. R. BARRoso considera que o novo direito constitucional ou neoconstitucionalismo se desenvolveu na segunda metade do século passado na Europa, chegando ao Brasil com o advento da Carta de 88 , propondo uma mudança de paradigmas, fundada na atribuição de força normativa à Constituição, no alargamento das fronteiras da interpretação constitucional e na expansão da justiça constitucional. Para essa teoria, os valores contidos nos princípios e regras que formam a Constituição estão presentes em todo o ordenamento jurídico e se propagam por meio da jurisdição constitucional. A partir disso, conclui o autor, resultam os seguintes

327 Essa é uma sumária visão pós-positivista da evolução do pensamento jurídico. Cf. L. R. BARROSO, Neoconstitucionalismo e constitucionalização do Direito ( $O$ triunfo tardio do direito constitucional no Brasil), disponível (on line) in www. migalhas.com.br/arquivo_artigo/art04102005.htm., [24.10.07].

${ }^{328}$ E. S. RAMOS, Parâmetros dogmáticos do ativismo judicial em matéria constitucional, cit., p. 263.

${ }^{329}$ L. R. BARroso, Neoconstitucionalismo e constitucionalização do Direito (O triunfo tardio do direito constitucional no Brasil), cit.

${ }^{330}$ L. R. BARroso, Neoconstitucionalismo e constitucionalização do Direito (O triunfo tardio do direito constitucional no Brasil), cit. 
princípios: "a aplicabilidade direta da Constituição" ou o reconhecimento de sua força normativa; "a inconstitucionalidade das normas incompatíveis com a carta constitucional"; e, sobretudo, a interpretação das normas infraconstitucionais conforme a Constituição.

Em relação à inconstitucionalidade das normas que contradizem a Constituição, não soa como uma lógica exclusiva dessa nova corrente. Conforme ensinou K. HESSE - indo além dos elementos clássicos de interpretação da lei formulados por Savigny:

"A teoria tradicional da interpretação pretende, (...), revelar a vontade (objetiva) da norma ou a vontade (subjetiva) do legislador através da análise do texto, do seu processo de criação, das suas conexões sistemáticas e dos seus antecedentes, assim como, finalmente, do sentido e da finalidade (a 'ratio' e o 'telos') da norma.", 331

A diferença do pós-positivismo para com a teoria tradicional se apresenta: a) na forma como L. R. BARROSO propõe que se proceda a essa interpretação; b) nos limites do julgamento das incompatibilidades e à aplicação da Carta e; c) na extensão ou grau da expansão da jurisdição constitucional e seus limites (ou a inexistência deles). $\mathrm{Ou}$ seja, o pós-positivismo centra-se na proposição de uma nova modalidade de interpretação constitucional e na ampliação do papel do Poder Judiciário. A aplicação dos princípios na tarefa interpretativa constitucional não é de todo pioneira do pós-positivismo. Antes, as divergências entre as duas correntes - tradicional e pós-positivista - pairam sobre a extensão e os limites para aplicação desses princípios.

Ao tratar dos princípios instrumentais da interpretação, L. R. BARROSO aponta os seguintes: o da supremacia da Constituição, o da presunção de constitucionalidade das normas e dos atos do Poder Público, o da interpretação conforme a Constituição, o da unidade, o da razoabilidade e o da efetividade. ${ }^{332}$ Diz o autor que, apesar da interpretação jurídica tradicional resolver de fato a maior parcela das situações, não é mais suficiente para a solução dos problemas relacionados com a realização da vontade constitucional. Propõe, então, uma "nova interpretação constitucional" 333. Esta se caracteriza como sendo baseada na subsunção: a norma abstrata deve oferecer soluções jurídicas e ao juiz cabe identificar a norma aplicável para solucionar o caso concreto. ${ }^{334}$

\footnotetext{
${ }^{331}$ K. HESSE, A interpretação constitucional, cit., p.104.

332 Para detalhamento de cada um desses princípios, v. L. R. BARroso, Interpretação e Aplicação da Constituição, cit., p.151-246.

${ }^{333}$ L. R. BARroso, Neoconstitucionalismo e constitucionalização do Direito (O triunfo tardio do direito constitucional no Brasil), cit.

${ }^{334}$ L. R. BARROSO considera o sincretismo "consciente e coerente" inevitável e desejável. Cf. Interpretação e Aplicação da Constituição, cit. Desta opinião não compartilha L. VIRGílio AfONSO DA SILVA, cf., Interpretação constitucional e sincretismo metodológico, cit., p. 140-155.
} 
Apoiando-se em PETER HÄBERLE, para quem a "interpretação é um processo aberto", o Ministro Gilmar Mendes, entende que a doutrina tradicional padece de um grande déficit ao adotar o método hermenêutico clássico no plano da interpretação constitucional. De acordo com o Ministro Gilmar Mendes, as premissas básicas da doutrina clássica são: "a) a Constituição enquanto lei há de ser interpretada da mesma forma que se interpreta qualquer lei; b) a interpretação da lei está vinculada às regras da hermenêutica jurídica clássica". "Contra essa orientação", recorda o Ministro Gilmar Mendes, "levantouse a proposta de utilização da tópica, (...), como método orientado ao problema". O controle constitucional "aprecia a relação da lei e o problema que se lhe apresenta em face do parâmetro constitucional" 335 .

Entendimento semelhante é compartilhado por K. HESSE, que relata a incapacidade das "regras tradicionais de interpretação" de oferecerem uma explicação que não parcial sobre a forma com que se elaboram as decisões judiciais. $\mathrm{O}$ autor que demonstra que a prática se orienta para uma interpretação vinculada ao objeto e ao problema, pois "não existe interpretação constitucional desvinculada dos problemas concretos" ${ }^{336}$. Porém, como adverte J. MIRANDA,

"exactamente porque a interpretação constitucional vive paredes-meias com a política é que a máxima objectividade possível deve ter-se como um escopo fundamental, muito mais propiciada pela utilização dos instrumentos jurídicos clássicos - os quais não têm de se confundir, insista-se, com pressupostos positivistas - do que pela formulação de argumentos para problemas específicos." 337

Para J. MiRAndA, "mesmo um autor como K. HeSSE, que enfatiza o caráter aberto e criador da interpretação constitucional, em necessário contato com o problema, entende que o método tópico pode ter um lugar limitado nesta interpretação", pois - continua o autor português - a atividade interpretativa "tem que estar atenta aos valores sem dissolver a lei constitucional no subjectivismo ou na emoção política" ${ }^{338}$.

335 G. F. MENDES, Controle de Constitucionalidade: hermenêutica constitucional de revisão de fatos $e$ prognoses legislativos pelo órgão judicial, in Revista de Direito Constitucional e Internacional, Coord: MARIA GARCIA, N. 31, Ano 8, abr/jun/2000, São Paulo, IBDC, p. 90, 92-93 e 100.

${ }^{336}$ K. HESSE, A interpretação constitucional, cit., p. 108 e 110-111. Em igual sentido, encontra-se a lição de PAULO BONAVIDES, que descreve com maestria o método tópico de interpretação constitucional, como sucessor do positivismo racionalista, cujo foco está no problema a ser decidido. Cf. P. BonAVIDES, $O$ método tópico de interpretação constitucional, Revista de Direito Público, n. 98, abr/jun 1991, p. 5-11.

${ }^{337}$ J. Miranda, Teoria do Estado e da Constituição, cit., p. 450.

${ }^{338}$ J. MiRANDA, Teoria do Estado e da Constituição, cit., p.451. 


\subsubsection{Métodos hermenêuticos}

Nesse ponto, faz-se uma breve digressão. Conforme assevera EROS GRAU, é praticamente impossível fixar critérios absolutos de interpretação, fazendo-se premente o emprego de vários métodos, que refletem muito mais uma postura ideológica do que simples preferência por um ou outro ${ }^{339}$.

Face ao debate ínsito à fundamentação encontrada nos votos objetos de análise desse estudo, conveniente recordar brevemente os métodos hermenêuticos. Na lição de J. Afonso DA Silva, “o sentido da Constituição se alcançará pela aplicação de três formas de hermenêutica: a) a hermenêutica das palavras; b) a hermenêutica do sentido; c) a hermenêutica contextual" ${ }^{340}$. Tais formas estão conformes às diretrizes da tradição romano-germânica. A primeira de suas ordens aponta que "a atuação do intérprete deve conter-se sempre dentro dos limites e possibilidades do texto legal. Estamos falando da interpretação gramatical, que não pode ser desprezada" ${ }^{341}$, devendo sempre se optar pelo resultado compatível da norma interpretada com a Constituição. A segunda, diz que os métodos sistemático e teleológico, por sua objetividade, têm preferência sobre o históricosubjetivo $^{342}$. Detalhando cada método, tem-se que a interpretação gramatical é considerada o ponto de partida. Porém, segundo L. R. BARROSO, não se pode ficar adstrito a esse método tão somente. De outro lado, a leitura gramatical se coloca como o limite máximo da atividade criadora do intérprete, como nos traz o próprio L. R. BARROSO, citando decisão do Tribunal Constitucional Federal alemão: “Através da interpretação não se pode dar a uma lei inequívoca em seu texto e em seu sentido, um sentido oposto (...)" ${ }^{343}$. Alertase também ao fato de que, quando um novo texto constitucional mantém ou elimina um dispositivo constante na antiga Carta, presume-se que o constituinte o fez intencionalmente, desejando ou manter ou modificar o entendimento que refletia o preceito anterior. A busca do significado da norma pela análise dos precedentes legislativos, ou seja, da vontade histórica do legislador, retrata a interpretação histórica, que traz valores sociais e ideológicos à tona.

\footnotetext{
${ }^{339}$ E. R. GRAU, A ordem econômica na Constituição de 1988, cit., p. 147-154.

${ }^{340}$ J. AfONSO DA SILVA, Interpretação da Constituição, in TCM Informativo, São Paulo, n. 27, jun/jul 2005, p. 21-22. Pode-se citar também como exemplo de métodos hermenêuticos os seguintes: o método jurídico ou hermenêutico clássico; o tópico-problemático; o hermenêutico-concretizador; o científico espiritual; e o normativo estruturante.

${ }^{341}$ L. R. BARROSO, Interpretação e Aplicação da Constituição, cit, p. 127-131.

${ }^{342}$ L. R. BARROSO, Interpretação e Aplicação da Constituição, cit., p. 124-140.

${ }^{343}$ L. R. BARROSO, Interpretação e Aplicação da Constituição, cit., p.130.
} 
A interpretação sistemática ocupa, junto com a teleológica, posição de primazia, segundo L. R. BARroso. A primeira decorre do princípio da unidade da Constituição, segundo o qual o ordenamento jurídico é um sistema de preceitos hierarquizados e coordenados, devendo ser interpretado como um todo. Assim também se encontra no saber de E. R. GRAU, para quem a norma deve ser concebida como parte de um sistema e, portanto, “(...) não se interpretam textos normativos constitucionais, isoladamente, mas sim a Constituição, no seu todo" ${ }^{344}$. Já pelo método teleológico, cuja atribuição teórica é concedida principalmente a Ihering, as normas devem ser interpretadas de acordo com sua finalidade.

Até aqui, não se nota significativa divergência do posicionamento póspositivista em relação hermenêutica tradicional. Porém, L. R. BARROSO adiciona mais uma modalidade de interpretação às tradicionais: a evolutiva ${ }^{345}$, fundada na chamada ratio legis, que é o fundamento racional que acompanha a norma durante sua vigência. Nas palavras de L. R. BARRoso, enquanto a interpretação histórica cuida da occasio legis, e considera apenas o momento da elaboração da norma, a interpretação teleológica deve captar a evolução do conceito sem modificação no texto, uma força dinâmica, a ratio le gis ${ }^{346}$.

Mas a dissonância vai mais além. L. R. BARROSO considera a possibilidade legítima de mutação da Constituição por duas formas: a conhecida reforma do texto pelo poder constituinte derivado e - a novidade - através do recurso aos meios interpretativos, considerando tal modalidade interpretativa de "um processo informal de reforma do texto da Constituição" ${ }^{347}$, atribuindo novos conteúdos à norma constitucional, por razões de ordem histórica, política e social. Para o autor, a longa tradição autoritária mantém a interpretação constitucional evolutiva em limites extremamente contidos.

L. R. BARROSO diz propor não a eliminação total de quaisquer limites, mas a extensão destes. Não somente confessa que a ausência total de limites seria tão perigosa para a convalidação de abusos autoritários, como também relata que "a interpretação evolutiva, sem reforma da Constituição, há de encontrar limites”. Segundo o autor, sua proposta está centrada muito mais na medida da amplitude desses limites, do que na eliminação dos mesmos - como por vezes deixa transparecer. Para L. R. BARRoso, o primeiro desses limites é dado pelo próprio texto. Além desse, têm-se os princípios

\footnotetext{
${ }^{344}$ E. R. GRAU, A ordem econômica na Constituição de 1988, cit., p. 150.

${ }^{345}$ L. R. BARROSO, Interpretação e Aplicação da Constituição, cit., p. 145-149.

${ }^{346}$ L. R. BARROSO, Interpretação e Aplicação da Constituição, cit., p. 139. Como exemplo, o autor cita o art. $3^{\circ}$. de nossa Carta Magna de 1988, que traz as finalidades da República brasileira, figurando como vetor de interpretação do que se pretende alcançar no Estado Democrático de Direito.

${ }^{347}$ L. R. BARroso, Interpretação e Aplicação da Constituição, cit., p. 146
} 
fundamentais do sistema, que são intangíveis. Revela o autor: ainda que "as alterações informais introduzidas pela interpretação" sejam admissíveis, "não poderão contravir os programas constitucionais" 348 .

O que se conclui do exposto é que seu posicionamento acaba se configurando contraditório, pois o próprio autor sugere a existência de limites à atividade hermenêutica, ao mesmo tempo em que aceita a alteração constitucional via interpretação. Parece querer conciliar o inconciliável. O mesmo autor sugere, primeiramente, o reconhecimento da normatividade dos princípios, qualitativamente diferente da normatividade das regras. ${ }^{349} \mathrm{E}$, em segundo lugar, atribui ao juiz um papel de "coparticipante do processo de criação do Direito, completando o trabalho do legislador" ${ }^{350}$, fazendo valorações e realizando escolhas, "entre soluções possíveis". 351

Ainda quanto aos métodos hermenêuticos, de acordo com o Ministro Gilmar Mendes, "a questão metodológica coloca-se no centro da reflexão sobre o papel que deve desempenhar a Corte Constitucional”, o que, por sua vez, traz indagações sobre a tentativa de conciliação entre a "democracia constitucional com jurisdição constitucional", tais como: "a) estaria o legislador submetido, de forma definitiva às decisões da Corte Constitucional?; (...); c) qual o direito que assegura ao Tribunal Constitucional a possibilidade de impor o seu entendimento ao legislador democraticamente eleito?" 352

De acordo com Menelick de Carvalho NetTo, a mudança de paradigmas do Estado Social de Direito para o Estado Democrático de Direito trouxe suas exigências ao exercício hermenêutico do Judiciário, com premência do retrabalho de princípios e regras no novo ordenamento vigente. Como exemplo desses princípios cita o autor a legalidade, a segurança jurídica e o sentimento de justiça como valores que defluem das decisões judiciais no Estado Democrático de Direito ${ }^{353}$. O direito integrado por princípios - normas de conteúdo aberto que são - requer uma interpretação que assegure solidez à ordem jurídica de um Estado Democrático de Direito. A legitimidade da ordem jurídico-democrática exige a consistência das decisões no que se refere tanto ao tratamento

\footnotetext{
${ }^{348}$ L. R. BARROSO, Interpretação e Aplicação da Constituição, cit., p. 149.

349 Isto é para L. R. BARroso, "um símbolo do pós-positivismo". Cf. Interpretação e Aplicação da Constituição, cit

${ }^{350}$ Artigo $1^{\circ}$, parágrafo único, Constituição Federal da República do Brasil de 05.10.88.

${ }^{351}$ Interessante notar que o autor coloca certos parâmetros, sem ir a fundo na discussão de quais são. Cf. L. R. BARRoso, Interpretação e Aplicação da Constituição, cit. Nesse ponto é que surge a questão dos limites à atividade do intérprete.

352 G. F. MENDES, Controle de Constitucionalidade: hermenêutica constitucional de revisão de fatos $e$ prognoses legislativos pelo órgão judicial, cit., p. 91.

353 M. C. NETTO, A hermenêutica constitucional sob o paradigma do Estado Democrático de Direito, in Notícia do Direito Brasileiro, N. 6, Universidade de Brasília, p. 233-249.
} 
anterior de casos análogos, como ao sistema normativo vigente. Portanto, nada mais imprescindível do que encontrar os limites para a atividade interpretativa, de modo que não se deturpe essa legitimidade.

\subsubsection{Os limites da interpretação constitucional $e$ do poder normativo dos Tribunais}

O debate quanto à função da jurisdição, assim como ocorreu na teoria constitucional norte-americana - onde liberais propunham o judicial review e um maior ativismo judicial, encontrando resistência nos chamados conservadores, defensores do contencionismo judicial e da interpretação nos moldes clássicos - também chegou ao Brasil, dado a universalidade de seu caráter.

Nesse âmbito de discussão, muito se falava no "déficit democrático" do Poder Judiciário. As críticas se fundavam em dois elementos: a soberania do parlamento e a divisão de Poderes. O primeiro, dizia da intangibilidade da lei parlamentar e a soberania do legislador, que deram lugar à supremacia da Constituição. O segundo acomodou a percepção de que as questões constitucionais não são somente políticas. Como relata VITAL MoREIRA, hoje não faz mais sentido questionar a legitimidade da justiça constitucional. Ela passou a ser elemento necessário ao Estado Democrático de Direito. ${ }^{354}$

Ao tratar da imprescindibilidade da Corte Constitucional, o Ministro Gilmar Mendes relembra, todavia, que ainda que "se deva reconhecer a legitimação democrática dos juízes, (...) não se pode deixar de enfatizar que aqui também reside aquilo que Grimm denominou de risco democrático". Isso ocorre, segundo o autor, porque "as decisões da Corte Constitucional estão inevitavelmente imunes a qualquer controle democrático". Adiciona ainda que, "eventual correção da jurisprudência de uma Corte Constitucional somente há de se fazer, quando possível, mediante Emenda". Por fim, conclui o Ministro Gilmar Mendes alertando que "essas singularidades demonstram que a Corte Constitucional não está livre de converter uma vantagem democrática num eventual risco para a democracia", pois, ao mesmo tempo em que "a jurisdição constitucional pode

\footnotetext{
${ }^{354}$ V. MOREIRA, Princípio da maioria e princípio da constitucionalidade - legitimidade e limites da justiça constitucional, in Legitimidade e legitimação da Justiça constitucional - Colóquio no $10^{\circ}$. Aniversário do Tribunal Constitucional, Coimbra, Coimbra editora, 1995, p. 195-196.
} 
contribuir para reforçar a legitimidade do sistema, (...), pode ela também bloquear o desenvolvimento constitucional do País" ${ }^{355}$.

Colocado o risco que uma atividade jurisdicional sem parâmetros pode ocasionar, é tempo de se recordar a lição de V. MoREIRA, para quem "o que está presente em causa é a extensão e os limites da jurisdição constitucional", ou seja, saber como o princípio da maioria serve de limite aos poderes do juiz constitucional. Em outras palavras, ele não deixou de ser relevante para definir os parâmetros e delimitar poderes. Afirma V. MOREIRA que a justiça constitucional "não usurpa o papel do legislador ordinário", substituindo-se àquele, ainda que nas escolhas constitucionalmente admissíveis. Em visão oposta à de L. R. BARROSO, Moreira alerta que o juiz deverá "observar precipuamente os limites aos seus poderes, que decorrem da Constituição ou são inerentes à fiscalização da constitucionalidade". Assim, "não lhe compete substituir-se ao legislador na formulação das soluções conformes à Constituição",356. Aqui, continuam a ter plena validade as limitações decorrentes do princípio da maioria e da separação de Poderes. "É à maioria democraticamente legitimada (...) a quem compete fazer as leis e não aos juízes", complementa o autor. Como corolário inevitável,

\footnotetext{
"na interpretação conforme a constituição, o juiz constitucional não pode (...) atribuir à norma um sentido que não possa ser reconduzível à vontade do legislador, pois de outro modo, tornar-se-á o verdadeiro legislador. O sentido conforme a Constituição há de ser um dos sentidos possíveis da norma (...)." 357
}

Com isso, exceto se autorizado pela Constituição, o juiz não pode emitir normas substitutivas às que declarar inconstitucionais. Além do mais, o Tribunal diante da incompatibilidade parcial, não poderá proceder à criação normativa. $\mathrm{O}$ mesmo se aplica perante omissões normativas. Não é outro o ensinamento de J. AFONSO DA SILVA, "pois a interpretação há de ser um meio de desvendar o sentido dos textos jurídicos, nunca um processo legislativo ou constituinte de novas normas." 358

Dois pontos são cruciais para a compreensão da crítica ao posicionamento adotado pelas Cortes jurídicas pátrias: a extensão e os limites da

\footnotetext{
355 G. F. MENDES, Controle de Constitucionalidade: hermenêutica constitucional de revisão de fatos e prognoses legislativos pelo órgão judicial, cit., p. 97-98.

356 V. Moreira, Princípio da maioria e princípio da constitucionalidade - legitimidade e limites da justiça constitucional, cit., p. 195-196.

${ }^{357}$ V. MoReIRA, Princípio da maioria e princípio da constitucionalidade - legitimidade e limites da justiça constitucional, cit., p. 196.

${ }^{358}$ J. AFONSO DA SILVA, Interpretação da Constituição, cit., p. 21.
} 
legitimidade democrática de nossas Cortes, tópico tratado acima, e; a divisão de Poderes, presente em nossa Carta Maior como cláusula pétrea. ${ }^{359}$

O significado da separação de Poderes remonta à razão de sua fórmula: por que assegurar a independência dos Poderes? Para que exista a autonomia dos órgãos no exercício de suas atribuições, sem invadir a esfera de competências de outro Poder. Cada ramo de poder se estabelece sem interferência dos outros. A questão pode soar óbvia, mas é importante tê-la de modo constante em mente quando da leitura das decisões das Cortes nacionais, em especial na análise dos casos em tela. Como bem lembra CHRISTIANE Boulos, trazendo à luz a premência da harmonia e equilíbrio entre os Poderes, os freios e contrapesos surgiram para evitar feudos de poder, exacerbação e absolutismo. Sem isso, a repartição do exercício do poder perderia sua razão de $\operatorname{ser}^{360}$. Todos os Poderes agem com o fim comum, constitucionalmente determinado. Porém, cada qual desempenha seu papel, que é bem delimitado pelo texto constitucional. A suscitação de possível ativismo judicial encontra, para seus críticos, limites estabelecidos pela definição atribuída pelo texto constitucional aos papéis dos órgãos jurisdicional e legislativo. Desde a primeira Carta republicana até a vigente, o controle abstrato de normas infraconstitucionais evoluiu para a concentração do controle de constitucionalidade em nossa Suprema Corte, imbuída da função de guarda da supremacia do Texto Maior, promovendo a jurisdicionalização de questões então consideradas políticas. Por sua vez, a atividade criadora legislativa está submetida à supremacia da Constituição e encontra seus limites de atuação na própria Constituição e no mecanismo de controle de constitucionalidade. O Poder Judiciário desempenha, nos termos de M.G. FERREIRA FILHO, um poder negativo, de veto, assemelhando-se à faculdade de impedir, retratada por MONTESQUIEU, e que tem sua abrangência estendida por todo o campo político, desde as eleições, passando pelos atos da administração e por todo processo legislativo. ${ }^{361}$ Os defensores de um maior ativismo do Judiciário preveem uma extensão desse Poder, não se limitando mais a ser apenas negativo, de impedimento, mas um exercício positivo, no sentido de um Judiciário atuante por meio da interpretação do ordenamento. Mas qual a posição adotada pelo Supremo

\footnotetext{
${ }^{359}$ A fórmula tripartite da separação de poderes está contida no art. $2^{\circ}$. e protegida no art. 60 , parágrafo $4^{\circ}$., III. Constituição Federal da República do Brasil de 05.10.88.

${ }^{360}$ C. Boulos, Controle Preventivo Jurisdicional de Constitucionalidade - Critérios para sua adoção no Brasil, Tese de doutorado defendida na Faculdade de Direito da Universidade de São Paulo, 2006, p. 191200.

${ }^{361}$ M. G. FerreIRA Filho, Aspectos do Direito Constitucional Contemporâneo, São Paulo, Saraiva, 2003, p. 212.
} 
Tribunal Federal? Há pouco mais de sete anos, encontra-se clara sua posição no julgamento do acórdão cuja ementa é transcrita a seguir:

"INTERPRETAÇÃO DO ORDENAMENTO POSITIVO NÃO SE CONFUNDE COM O PROCESSO DE PRODUÇÃO NORMATIVA. O ordenamento normativo nada mais é senão a sua própria interpretação, notadamente quando a exegese das leis e da Constituição emanar do Poder Judiciário, cujos pronunciamentos qualificam-se pela nota da definitividade. A interpretação, qualquer que seja o método hermenêutico utilizado, tem por objetivo definir o sentido e esclarecer o alcance de determinado preceito inscrito no ordenamento positivo do Estado, não se confundindo, por isso mesmo, com o ato estatal de produção normativa. Em uma palavra: o exercício de interpretação da Constituição e dos textos legais - por caracterizar atividade típica dos Juízes e Tribunais - não importa em usurpação das atividades" ${ }^{362}$.

Fato inegável é que o entendimento da Suprema Corte, como transparentemente se configura na análise da decisão supracitada, afasta-se de qualquer possibilidade de produção normativa, ou seja, de “criação", bem como reforça a separação dos Poderes. A Constituição e os textos legais continuam sendo os limites e parâmetros para que a atividade interpretativa jurisdicional não invada a esfera de atuação dos outros Poderes. Isso é reafirmado em recente decisão:

CONTROLE JURISDICIONAL E SEPARAÇÃO DE PODERES. Nem se diga, de outro lado, na perspectiva do caso em exame, que a atuação do Poder Judiciário, nas hipóteses de lesão, atual ou iminente, a direitos subjetivos amparados pelo ordenamento jurídico do Estado, configuraria intervenção ilegítima dos juízes e Tribunais na esfera de atuação do Poder Legislativo. Eventuais divergências na interpretação do ordenamento positivo não traduzem nem configuram situação de conflito institucional, especialmente porque, acima de qualquer dissídio, situa-se a autoridade da Constituição e das leis da República. Isso significa, na fórmula política do regime democrático, que nenhum dos Poderes da República está acima da Constituição e das leis. Nenhum órgão do Estado - situe-se ele no Poder Judiciário, ou no Poder Executivo, ou no Poder Legislativo - é imune à força da Constituição e ao império das leis. Uma decisão judicial - que restaura a integridade da ordem jurídica e que torna efetivos os direitos assegurados pelas leis - não pode ser considerada um ato de interferência na esfera do Poder Legislativo, consoante já proclamou o Plenário do Supremo Tribunal Federal, em unânime decisão: "O CONTROLE JURISDICIONAL DE ABUSOS PRATICADOS POR COMISSÃO PARLAMENTAR DE INQUÉRITO NÃO OFENDE O PRINCÍPIO DA SEPARAÇÃO DE PODERES. (...)" ${ }^{363}$ (grifos nossos).

Da decisão supra, extraem-se diversas conclusões. Entre essas, tem-se as bases para os limites da interpretação, que se perfazem na supremacia da Constituição e das leis sobre os três Poderes. PEDro CRUZ VILlalón, ao distinguir a atuação do Judiciário dos atos baseados em critérios essencialmente políticos, por se exigir desta a fundamentação juridicamente argumentada e racionalizada de suas decisões, afirma: "O que se faz dessa forma argumentada é interpretar a Constituição, e não se faz outra coisa,

${ }^{362}$ STF, $2^{\text {a }}$. Turma, AGREG-AGI N. 250.730-1/MG, rel. Min. Celso de Mello, DJ 07.04.2000.

${ }^{363}$ STF, HC 88015-MC/DF, rel. Min. Celso de Mello, RTJ 173/805-810, 806. 
fundamentalmente, não se legisla" ${ }^{364}$ Em igual sentido, V. MOREIRA reforça a questão das barreiras à livre interpretação, considerando que, ao juiz constitucional "não (lhe) compete substituir-se ao legislador na formulação das soluções conformes à Constituição." 365 Trilhando o mesmo caminho e fechando o raciocínio, CHRISTIAN STARCK revela com clareza a relação entre a interpretação jurídica e a separação do exercício das funções de cada Poder, mostrando que as regras de interpretação não podem apartar-se da repartição de funções, sob pena da supremacia da Constituição e da jurisdição constitucional perderem sua razão de ser. ${ }^{366}$ Igualmente valiosos os ensinamentos de J. AFONSO DA SILVA, que predizem: “(...) a interpretação constitucional tem que seguir alguma orientação teórica. (...) Há regras que o intérprete tem que seguir, que dependem da orientação que ele assume, que se manifestam nos chamados métodos de interpretação, (...).” E, por fim, fechando a questão da legitimação dos Tribunais para promover mudanças por meio de interpretação constitucional, KARL LARENZ, coloca com clareza os limites do desenvolvimento do direito superador da lei:

“(...) o limite do desenvolvimento judicial do Direito radica aí onde a resolução exigida já não pode ser fundamentada só em considerações jurídicas, mas exige uma decisão política, orientada a pontos de vista de oportunidade. Encontrá-la é, no Estado democrático, em princípio, matéria do legislador. Os tribunais carecem de competência para promover a conformação social." 367 (grifos nossos)

Em linha com a doutrina que proclama a adoção de orientação ou balizamento para evitar que a interpretação jurídica conduza a maiores "riscos democráticos”, encontra-se em K. HESSE uma clara definição no que tange aos limites da atividade exegética. O balizamento e os limites se encontram no "programa normativo", que "deverá apreender-se pela interpretação desse texto no que diz respeito ao seu significado vinculante para a solução do problema." Nesse âmbito, os métodos de interpretação tradicionais podem "ajudar a se fazerem precisas possíveis variações de sentido no espaço delimitado pelo texto". Embora tais métodos não propiciem resposta suficiente quando utilizados isoladamente, não deixam, por isso, de fornecer o

\footnotetext{
364 P. C. Villalón, Legitimidade da justiça constitucional e princípio da maioria, in Legitimidade e legitimação da Justiça constitucional - Colóquio no $10^{\circ}$. Aniversário do Tribunal Constitucional, Coimbra, Coimbra editora, 1995, p. 85-90.

${ }^{365}$ V. MoreIRA, Princípio da maioria e princípio da constitucionalidade - legitimidade e limites da justiça constitucional, cit., p. 196.

${ }^{366}$ C. STARCK, La légimité de la justice constitutionelle et lê príncipe démocratique de la majorité, in Legitimidade e legitimação da Justiça constitucional - Colóquio no 10 ${ }^{\circ}$. Aniversário do Tribunal Constitucional, Coimbra, Coimbra editora, 1995, p. 73.

367 K. LarenZ, Metodologia da Ciência do Direito, trad. José Lamego, $3^{\mathrm{a}}$. ed., Lisboa, Fund. Calouste Gulbenkian, 1997, p. 608-609.
} 
enquadramento último da atividade hermenêutica constitucional. A realidade deve ser apreendida nos "termos demarcados no programa normativo, em sua forma e caráter materialmente - e, não raro, juridicamente - determinados." Esse procedimento proporciona concretização e "uma fundamentação racional e controlável, como, ademais, assegura em boa medida a adequada solução do problema; (...)" 368 .

Igualmente sem compartilhar das audácias do pós-positivismo, K. HESSE entende possível que o "procedimento tópico vinculado, em coerência ao caráter da Constituição, ao problema concreto, mas sempre guiado e orientado pela norma, terá o máximo de possibilidades para chegar a resultados sólidos, racionalmente explicáveis e controláveis", por mais que as decisões jurídicas não consigam ser racionalizadas de todo. Tem-se a "racionalidade possível", cujo caráter difere das ciências exatas, mas que traz o mínimo balizamento a evitar os riscos de afronta aos princípios democráticos. Dado que "o Direito Constitucional não escrito não pode contradizer a constitutio scripta, esta última se converte em limite inultrapassável da interpretação constitucional" ${ }^{369}$, o que exclui a reforma da Constituição por interpretação, pois, conforme o autor, "onde o intérprete se impõe à Constituição, deixa de interpretá-la para mudá-la”, o que se traduz em uma conduta vedada pelo Direito. Disso decorrem, inclusive, "os limites que no Direito Constitucional se impõem ao pensamento tópico" ${ }^{370}$. Na mesma sintonia, alertando para os riscos do Estado de Direito cair "numa crise de confiança" quando os Tribunais assumem posições políticas por meio da interpretação, ensina K. LARENZ que

\footnotetext{
"não se pode 'estabelecer por si um Direito novo, que só um preceito constitucional haveria de realizar, (...) - que necessita, portanto, de ser precisado mais em pormenor pelo legislador -, resolvendo um caso que se lhe apresenta como se este Direito fosse já vigente." 371
}

Todo o acima exposto parece conflitar com as propostas pós-positivistas de interpretação aberta, sem limites. As considerações aqui trazidas parecem levar à conclusão de que a iluminação das novas considerações pós-positivistas não atribui a devida importância à questão dos limites da interpretação jurídica, ponto chave da atividade exegética, que justamente não pode ser desconsiderado. Na verdade, o pós-

\footnotetext{
${ }^{368}$ K. HESSE, A interpretação constitucional, cit., p. 111-112.

${ }^{369}$ O princípio da legalidade é aplicado não só como ponto de partida para a apreensão do sentido por parte dos intérpretes constitucionais, assim também como limite da interpretação. Deve o intérprete captar o sentido do texto, sem extrapolar ou contradizer os preceitos constitucionais.

${ }^{370}$ K. HESSE, A interpretação constitucional, cit., p. 112-117.

${ }^{371}$ K. LARENZ, Metodologia da Ciência do Direito, cit., p. 607 e 609. Sobre os riscos da adoção de posições políticas pelos Tribunais, alerta o autor: "Em toda a louvável disponibilidade para desenvolver o Direito de modo criador os tribunais deveriam ter sempre presente este perigo, para não defraudarem o limite da sua competência que, em concreto, não é, com frequiência, facilmente cognoscível."
} 
positivismo de L. R. BARROSO diz levar em conta os limites que se impõem. Todavia, sua posição não é compatível suas propostas de mutação via interpretação e de maior ativismo judicial. As modernas posições, que levam amplamente em consideração a força normativa dos princípios, acabam por ser demasiadamente permissivas, ao autorizar que a atividade criadora do intérprete atente contra as previsões contidas no ordenamento, mesmo quando a realiza valorizando a moralidade e a eficiência, pois se está a jogar por terra o princípio da unidade da Constituição. Ao assim agir, admite-se que o sistema jurídico comporta uma ilogicidade advinda de uma suposta convivência com normas posteriormente consideradas imorais, que, incongruentemente, estariam contidas no próprio ordenamento. E que seriam extirpadas, não pelos mecanismos estabelecidos pelo ordenamento - o do controle de constitucionalidade ou da alteração constitucional via Emenda - mas por simples interpretação jurisdicional, invocando-se a moralidade como seu pressuposto maior.

Colocada a superação do modelo hermenêutico do positivismo clássico do século XIX ao lado dos riscos assumidos pelo pós-positivismo ou neoconstitucionalismo, que ignora os limites estabelecidos à interpretação, qual caminho restará ao intérprete trilhar? A resposta parece bem delineada em E. S. RAMOS, que considera a moderna hermenêutica como superadora das dificuldades do positivismo clássico - dificuldades, estas, que foram ultrapassadas pela dogmática positivista do século XX. A solução se encontra, nas palavras do autor, na concepção da atividade de 'interpretação-aplicação' “como parte de uma estrutura lógica de compreensão complexa e dinâmica" que faz com que ambas as atividades, embora "mutuamente implicadas", sejam "lógica e conceitualmente distintas", o que acarreta em uma "dissociação lógico-temporal entre enunciado normativo e norma de decisão, em que o texto é o ponto de partida do processo hermenêutico, que culmina com a formulação da norma concretizada pelo intérprete-aplicador (...)",372. Desta forma, conclui E. S. RAMOS: "logrou-se, pois, obter um ponto de equilíbrio entre o primado do legislador e dos enunciados normativos por ele ditados", contornando os problemas do positivismo clássico em matéria interpretativa, de maneira satisfatória e condizente com as exigências do Estado Democrático de Direito, uma vez que

"eliminada a associação entre positivismo e subsunção mecânica, de índole lógicoformal, e afastada a referência a uma ordem de valores externa ao sistema jurídico, com interferência direta sobre a sua conformação, não há porque não se afirmar a perfeita compatibilidade entre os desenvolvimentos mais recentes da Teoria da Interpretação e o positivismo jurídico. Desse modo, não é apenas possível, mas, sobretudo, indispensável,

${ }^{372}$ E. S. RAMOS, Parâmetros dogmáticos do ativismo judicial em matéria constitucional, cit., p. 261-262. 
à luz do ideário democrático, trabalhar a teoria constitucional sob as premissas de um positivismo renovado pelas conquistas da moderna Hermenêutica, situando a discricionariedade envolvida na tarefa de atuação da Constituição no plano estritamente dogmático e submetendo tanto o legislador, ao concretizar na lei comandos constitucionais, quanto o juiz, ao escolher entre diferentes possibilidades exegéticas, às exigências do Estado de Direito.". 373 (grifos nossos)

Tendo em mente os limites que se colocam para que a atividade interpretativa não represente um "risco democrático", parte-se agora, para a verificação específica do tratamento hermenêutico dispensado nas decisões analisadas neste capítulo.

\subsubsection{A atividade hermenêutica $e$ normativa na recente jurisprudência eleitoral}

Uma vez expostas as bases da atividade hermenêutica e as propostas póspositivistas que inspiraram uma expansão das fronteiras da interpretação constitucional, completam-se os trabalhos desse capítulo revisando, ponto a ponto, o resultado da interpretação aplicada aos casos concretos em matéria eleitoral objetos de análise deste estudo, procurando apontar as diversas oportunidades, no âmbito eleitoral, nas quais o entendimento anteriormente prevalecente foi alterado por força de atividade interpretativa judicial.

\subsubsection{Coligações partidárias}

Com a edição das Resoluções N. 20.121 e N. 20.126 no ano de 1998, o TSE forneceu sua primeira interpretação sobre o instituto das coligações partidárias, veiculado no art. $6^{\circ}$. da Lei N. 9.504/97. Do posicionamento da Corte Eleitoral então firmado não constou qualquer vinculação obrigatória para as coligações estabelecidas para eleições presidenciais com outros pleitos. O entendimento foi fruto da interpretação de que apenas na mesma circunscrição seria obrigatória a manutenção da mesma configuração de alianças partidárias, o que ocorreria, por exemplo, na circunscrição estadual, vinculando os arranjos políticos formados para concorrer ao cargo de Governador com os de Senador, ambos do pleito majoritário.

${ }^{373}$ E. S. RAMOS, Parâmetros dogmáticos do ativismo judicial em matéria constitucional, cit., p. 263. 
Quatro anos mais tarde, as Resoluções N. 20.993 e N. 21.002, divulgadas pelo TSE no ano de 2002, apresentaram uma inovação interpretativa. Nada se alterara em termos do texto legal. Todavia, interpretou-se o mesmo dispositivo (art. $6^{\circ}$. da Lei das Eleições) de forma a alterar o entendimento que prevalecia até então. À expressão “mesma circunscrição" atribuiu-se novo significado, visando prestigiar o caráter nacional dos partidos políticos. Assim, pela nova posição do TSE, a circunscrição nacional passou a abranger a estadual, criando-se a verticalização das coligações - instituto que obrigaria, por via de regulamento do TSE, que os arranjos formados em nível estadual seguissem fielmente aqueles fixados para o pleito nacional.

Questionada no STF a constitucionalidade das supracitadas Resoluções do TSE editadas em 2002, a Corte Suprema não conheceria do objeto da ação (ADI N. 2.626), por entender que o TSE fez uso de mera interpretação da lei. O Excelso Pretório afastou, com isso, a análise de mérito sobre atentado ao princípio da anterioridade eleitoral, que restou claramente afetado com a normatização da Corte Eleitoral e assim validou a alteração em matéria eleitoral ocorrida a menos de um ano do pleito geral de 2002. Por conseguinte, julgou também não haver extrapolado o TSE sua competência normativa, ao introduzir a verticalização em nosso ordenamento ${ }^{374}$.

Do voto do Ministro Celso de Mello na citada ADI, capta-se sua compreensão a respeito da atividade interpretativa desenvolvida pelo STF naquela ocasião:

\footnotetext{
"Não se pode desconhecer que, no poder de interpretar o ordenamento jurídico, reside a magna prerrogativa judicial de estabelecer o alcance e de definir o sentido da vontade normativa proclamada pelo Estado.

Cumpre insistir que a função de interpretar as leis - cuja prática não faz instaurar situação de normatividade - revela-se prerrogativa essencial daqueles que as aplicam, incumbindo, ao Poder Judiciário, por efeito das próprias funções institucionais que lhe competem, o exercício dessa atribuição de ordem jurídica.

A norma jurídica - todos o sabemos - nada mais é, na expressão do seu sentido e na revelação do seu conteúdo, do que a sua própria interpretação. E foi, precisamente, o que ocorreu na espécie, em que o E. Tribunal Superior Eleitoral aprovou resolução veiculadora de conteúdo meramente interpretativo de certa norma legal, (...).”375
}

Posteriormente, julgando a constitucionalidade da EC-52/06, que eliminou definitivamente a verticalização, resolveu a Suprema Corte aplicar o referido princípio constante do art. 16 da Constituição, protelando para o pleito do ano de 2010, tão somente, a extinção da verticalização das coligações partidárias.

${ }^{374}$ V. STF, HC 88.015-MC/DF, rel. Min. Celso de Mello, RTJ 173/805-810, decisão na qual o STF entende que eventuais divergências interpretativas não configuram qualquer invasão de competência do Poder Legislativo.

${ }^{375}$ STF, Pleno, ADI N. 2.626 e N. 2.628, rel. ac. Min. Ellen Gracie, 18.04.02, DJ 05.03.04. 
Em suma, foi por força da ação interpretativa do Judiciário que nova regra eleitoral foi instituída e que seria extirpada pelo Legislativo não fosse nova e diversa interpretação fornecida pelo STF sobre a anterioridade da lei eleitoral para o assunto das coligações.

\subsubsection{Limitação das vagas nas Câmaras Municipais}

Estabelecidas pelo constituinte originário, as faixas que determinavam o número de Vereadores que um Município poderia criar, foram alteradas por meio de interpretação do TSE sobre o texto constitucional. O entendimento anterior ao julgamento do Recurso Extraordinário N. 197.917 privilegiava a autonomia municipal para definição, dentro dos parâmetros constitucionais, o exato número de cadeiras da vereança. Regulamentado o novo posicionamento pelo TSE (Resolução N. 21.702/04), passou-se a exigir a exata proporcionalidade fixada em tabela apresentada no ato regulamentar, decorrente de cálculo aritmético puro, de proporção entre a população e o número de vagas. Sob o manto da interpretação, ato normativo secundário do TSE introduziu nova matéria de âmbito eleitoral em pleno ano de eleições municipais, que viriam a ser afetadas pela nova regra, ao arrepio da anterioridade eleitoral.

A alteração de tal entendimento foi promovida pelo Legislativo por força da EC-58/09, que fixou novos limites para o cálculo do número de Vereadores municipais, criando, ademais, quase oito mil novos postos. A imediata vigência da Emenda foi obstada em decisão liminar do STF, com a aplicação do princípio da anterioridade eleitoral, desta feita.

\subsubsection{O fim da carreira política de Prefeito}

Com a edição da Resolução N. 18.110/92, o TSE introduziu a irreelegibilidade do Prefeito do Município-mãe para chefiar o Executivo do novo Município desmembrado (à época em que a reeleição não era permitida no ordenamento pátrio). Dez anos após, por meio da Resolução N. 21.297/02, o TSE interpretou que a candidatura a cargo de Prefeito de outro Município, vizinho ou não, caracterizaria "candidatura a outro cargo", devendo ser observada apenas a regra da 
desincompatibilização e não caracterizaria reeleição (sendo que pela EC-16/97 autorizavase a reeleição para cargos do Executivo por uma única vez).

Julgando o REspe N. 32.507/AL no ano de 2008, o Ministro Eros Grau apresentou seu entendimento sobre a interpretação constitucional que se aplicaria ao caso em tela:

\begin{abstract}
"A interpretação do direito não se resume a mero exercício de leitura. Fosse assim, bastaria a alfabetização para que todos pudessem exercer qualquer atividade jurídica, inclusive as que são próprias ao Poder Judiciário. A interpretação do direito, como observei em outra oportunidade, tem caráter constitutivo - não meramente declaratório, pois - e consiste na produção, pelo intérprete, a partir de textos normativos e dos fatos atinentes a um determinado caso, de normas jurídicas a serem ponderadas para a solução desse caso, mediante a definição de uma norma de decisão. Interpretar/aplicar é dar concreção [= concretizar] ao direito. Neste sentido, a interpretação/aplicação opera a inserção do direito na realidade; opera a mediação entre o caráter geral do texto normativo e sua aplicação particular; em outros termos, ainda: opera a sua inserção na vida. Quem interpreta a Constituição - e não simplesmente a lê - sabe que a regra do $\S$ $5^{\circ}$ do seu artigo 14 veda a perpetuação de ocupante de cargo de Chefe de Poder Executivo nesse cargo. Qualquer Chefe de Poder Executivo - Presidente da República, Governador de Estado e Prefeito Municipal - somente pode, no Brasil, exercer dois mandatos consecutivos no cargo de Chefe de Poder Executivo." 376
\end{abstract}

Com tal decisão, superou-se o entendimento que fora reafirmado na Resolução N. 21.465/03, na qual havia se ratificado que a candidatura para Prefeito em outro Município, desde que não desmembrado há menos de duas legislaturas e apesar do cargo ser idêntico, era considerado como "outro cargo", pois se tratava de "outra circunscrição". A nova interpretação do TSE em 2008 se deu sobre a expressão "outro cargo" que passou a significar qualquer mandato legislativo, ou qualquer outro de chefia do Executivo, exceto o de Prefeito Municipal. Assim, por ato interpretativo, restou decretado o fim da carreira dos Prefeitos itinerantes. Novamente, alterou-se a interpretação de dispositivo constitucional sem que houvesse qualquer reforma no texto da Carta Magna ou na legislação infraconstitucional, criando-se ou cancelando-se as regras vigentes ao sabor do entendimento dos ilustres Ministros que compunham os Tribunais a cada momento. Desta feita, a mudança de rumos ocorreu logo após o pleito eleitoral municipal de outubro de 2008, deixando incertezas para vários Municípios brasileiros que haviam acabado de reeleger Prefeitos itinerantes.

${ }^{376}$ TSE, RESPE N. 32.507, rel. Min. Eros Grau, 17.12.2008, DJ 17.12.08. 


\subsubsection{Sobrevida aos partidos "nanicos"}

Não pairavam dúvidas sobre a existência de autorização constitucional para que a lei ordinária estabelecesse a cláusula de barreira. O instituto foi regulamentado pela Lei dos Partidos Políticos em 1995, porém com eficácia protraída no tempo. Sua plena aplicação viria para as eleições de 2006. Chegada a hora, o TSE criou uma imensa confusão acerca da aplicação das regras de barreira, ao se pronunciar sobre os resultados do pleito de outubro de 2006, interpretando o art. 13 da Lei N. 9.096/95 para estabelecer o método de cálculo de exclusão dos partidos que não lograssem o resultado mínimo. Tudo isso forçou ao STF julgar apressadamente as ADI N. 1.351 e N. 1.354, nas quais a Corte Suprema valorou os princípios da isonomia e da proteção das minorias como aqueles que deveriam prevalecer na decisão. Interpretou o Excelso Tribunal que não se poderia permitir a criação de duas classes de partidos, uma delas privilegiada, à luz dos princípios constitucionais democráticos ora citados. Desprezou-se, assim, a autorização legada ao legislador ordinário para regular o funcionamento parlamentar constante do art. 17, V, da Constituição Federal, julgando-se inconstitucional a cláusula de barreira. Em suma, foi o Judiciário e não o Congresso quem decidiu sobre o retorno ou não da cláusula de barreira.

\subsubsection{Interpretação ou normatização?}

Em todas as decisões sobre matéria eleitoral que foram visitadas neste estudo, o principal questionamento incide sobre o modo de atuação dos Tribunais. Agiram as Cortes no limite de suas competências, desenvolvendo meramente atividade estritamente interpretativa, respeitando os limites impostos pelo ordenamento? Ou houve de fato uma real produção normativa por meio de ato interpretativo ou ato regulamentador, ocupando espaço reservado ao Poder Legislativo? Estas são, de fato, as questões de fundo do ativismo judicial: saber-se quando a atividade realizada pelas Cortes na decisão de tais matérias eleitorais configura-se mera interpretação ou quando atuaram positivamente os Tribunais, em plena ação de normatização, isto é, de produção de normas primárias.

A resposta naturalmente depende da corrente ideológica adotada. Obviamente, para os Ministros que levaram a cabo as mudanças promovidas no entendimento em matéria eleitoral, filiados, portanto, às correntes majoritárias que 
prevaleceram em cada ocasião, não há de se cogitar de qualquer atividade legislativa pelo Judiciário. Trata-se de mera interpretação. Ainda que se presenciasse divergência quanto à jurisprudência consolidada, o argumento para a mudança de rumos interpretativos se baseou na mutação constitucional, na atualização da Constituição e na conformidade com os princípios que esta alberga.

Para a corrente oposta, por diversas vezes as Cortes atribuíram ao texto legal significado diverso do veiculado na legislação. Interpretou de forma diversa os mesmos princípios que a Lei Fundamental contém desde sua promulgação. Com isso, alterou-se, em várias ocasiões, a jurisprudência prevalecente, com fundamento em mero ato interpretativo e no método evolutivo de interpretação, sob o pretexto de aplicação do princípio da não fossilização das normas constitucionais. Tal "atualização de normas" via interpretação constitucional nitidamente atentou contra a segurança jurídica do ordenamento, criando a imprevisibilidade da forma com que a Corte Suprema aplica seus poderes de guardiã da Carta Magna. Para essa corrente, os Tribunais atuaram legislando positivamente. Não se trata, pois, de ato interpretativo ou ato normativo secundário, uma vez que, realmente, introduziram regras até então inexistentes no ordenamento. A própria repentina alteração de entendimento sobre diversos tópicos eleitorais prova o abandono dos limites da interpretação, em prol de uma atividade verdadeiramente legislativa.

Nesse sentido, conforme estudado na decisão sobre a verticalização das coligações partidárias, o Procurador Geral da União, emitira parecer sobre a ADI N.2.626, entendendo que:

“(...) é óbvio que toda consulta somente pode ser formulada sobre normas legais relativas a matéria eleitoral (CE, art. 23, XII). Isso não significa, todavia, que a norma legal no caso inclui a pretendida vedação, tal como respondido, por maioria, pelo TSE, estabelecendo posteriormente nova regra, por resolução, inexistente nas instruções relativas às eleições de 1998 realizadas na vigência da mesma Lei N. 9.504/97 (Lei das Eleições). Toda consulta obviamente visa a obter do TSE a correta exegese de uma norma legal. Evidentemente, se a norma não inclui determinado conteúdo, a resposta à consulta não é interpretação: é criação de nova norma. Afirmar (...) que a consulta é sobre a exegese de norma é afirmar o óbvio. Não se trata de interpretação, contudo, a resposta que introduz no mundo jurídico vedação que não existe na lei a pretexto de interpretá-la." ${ }^{377}$ (grifos no original)

É certo que o poder normativo do TSE atribuído pelo art. 23, XII, do Código Eleitoral, lhe permite regulamentar matéria eleitoral por meio da expedição de Instruções e Resoluções. Segundo o Ministro Sepúlveda Pertence, "estas têm uma força normativa muito diversa da jurisprudência dos demais tribunais do País, precisamente por

${ }^{377}$ STF, Pleno, ADI N. 2.626, rel. ac. Min. Ellen Gracie, 18.04.02, DJ 05.03.04. 
dispor o TSE desse poder - muito mais como órgão de administração do processo eleitoral do que como órgão jurisdicional -, de dar feição normativa à sua inteligência da lei". Porém, como alerta o Ministro Pertence, "o ponto, então, a saber, é se houve alteração da regulamentação ou da interpretação - se quiserem - da mesma lei, de um processo eleitoral para o outro". ${ }^{378}$ E foi exatamente o que se observou nos casos em exame.

Após a profunda análise da atuação dos Tribunais ao decidir os quatro pontos eleitorais aqui expostos, conclui-se que o mau uso da interpretação jurídica visando atingir um determinado resultado vulnera seriamente as instituições democráticas. Ao leigo, as decisões parecem ter sido tomadas do seguinte modo: quer-se proibir a migração de Prefeitos, por ser atentatória ao princípio democrático da renovação nos cargos eleitorais? Altera-se o entendimento vigente e aplicam-se princípios para validarem o novo entendimento. Deseja-se reduzir as despesas municipais com suas Câmaras de Vereadores? Interpreta-se o texto legal empregando-se princípios constitucionais de forma a atingir tal resultado. A fidelidade partidária impõe a moralização necessária à política tão aguardada pela sociedade? Sobrevaloram-se os princípios que fortalecem os partidos políticos e entende-se que o texto constitucional já albergava tal entendimento há mais de vinte anos. $\mathrm{Na}$ interpretação sem limites tudo se pode. Sempre haverá uma forma de fundamentar a decisão.

O que se pretendeu aqui demonstrar não foram os eventuais erros no julgamento e na interpretação de cada questão eleitoral em si. Ainda que em prol de maior moralização e efetividade das instituições, mesmo quando o Poder Legislativo mostra-se inoperante, não se deve buscar uma interpretação que permita validar o entendimento que a sociedade gostaria a qualquer custo, incidindo em riscos à democracia. Fazer valer os desejos sociais é papel do parlamentar e não do juiz, no regime democrático entre nós estabelecido.

O tema da interpretação será retomado no próximo capítulo, quando se terá nova oportunidade de debater sobre o assunto e verificar como a situação se agravou no caso da fidelidade partidária, o maior exemplo presente de ativismo judicial e do uso da hermenêutica constitucional para se chegar a uma conclusão "socialmente desejável".

${ }^{378}$ STF, Pleno, ADI N. 2.626, rel. ac. Min. Ellen Gracie, 18.04.02, DJ 05.03.04. Cf. voto do Min. Sepúlveda Pertence, no qual o magistrado viria a responder afirmativamente à questão que colocou, entendendo ter atuado como legislador o TSE, o que se prova pela mudança da regulamentação e da interpretação entre as legislaturas. 


\section{A JURISPRUDÊNCIA SOBRE A FIDELIDADE PARTIDÁRIA}

\subsection{A relevância e a atualidade do tema}

Ao examinar-se a recente atuação do TSE e da Suprema Corte em matéria eleitoral, nota-se que a fidelidade partidária aparece como o principal tópico e como uma das mais acirradas polêmicas tanto no meio acadêmico, quanto no político e, por conseguinte, movimenta efusivamente a mídia. Tanto assim que professou o Ministro Gilmar Mendes:

\footnotetext{
"se penso em dez decisões emblemáticas do STF, não consigo excluir essa decisão do contexto de 1988. Realmente uma decisão que preserva a democracia no Brasil. Uma decisão verdadeiramente histórica. Talvez ela esteja entre as cinco mais importantes deste período de $88 ., 379$
}

Por esses motivos, o presente estudo dedica todo um capítulo ao tema, adotando-o como ponto central da análise de casos concretos, dos quais se pretende extrair conclusões a respeito do posicionamento dos Tribunais e seus efeitos para a democracia pátria. Não somente por sua atualidade, porém, acima desse fator, por envolver o elemento do mandato eleitoral, ponto sensível e estruturante da democracia.

A questão se reveste de especial destaque, como se observa na obra de Monica Herman Salem Caggiano, que frisa os aspectos da recorrência e cronicidade da relação fidelidade partidária x representação política, afirmando que:

\footnotetext{
"em cenário doméstico, a complexa e dramática questão atinente a medidas inibitórias do turismo interpartidário, da conhecida operação da danças das cadeiras, já se apresenta como problema recorrente. Em suma, é algo crônico que demanda um profundo exame e, certamente, um tratamento adequado para não atingir a essência do mandato representativo e, por via reflexa, o próprio princípio da representação, reduzindo-lhe a necessária densidade." 380
}

\footnotetext{
${ }^{379}$ STF, Pleno, ADI 3.999, rel. Min. Joaquim Barbosa, 12.11.08, DJE 17.04.09.

${ }^{380}$ M. HeRMAN SALEM CAGgIANO, A fenomenologia dos trânsfugas no cenário político eleitoral brasileiro, in Claudio Lembo (Coord.), M. Herman Salem Caggiano (Org.), O voto nas Américas, CEPES, 2008 p. 225 .
} 
A autora, uma das principais estudiosas do tema da fidelidade partidária, observa a tendência dos parlamentares brasileiros de trocarem de partido ao bel prazer, em uma "verdadeira peregrinação entre as diversas agremiações", demonstrando que "é da natureza político-partidária praticada entre nós e que gira, predominantemente, ao redor da figura do candidato e não da agremiação política que lhe sustenta a candidatura”, ao constatar que " $80 \%$ dos nossos parlamentares já pertenceram a alguma outra legenda, diferente daquela que os elegeu na última eleição" 381 .

O tema, além de sua relevância para a democracia pátria, sua atualidade e constante mutação, é dotado de polêmica suficientemente aguda a ponto de deixar transparecer uma crise entre os Poderes. Somam-se a essa problemática a transmutação promovida pelo fortalecimento da figura do partido político, a participação da sociedade em um debate que expôs diferentes pensamentos e o foco dado à questão pelo Supremo Tribunal Federal. São fatos que tornam o tema da fidelidade partidária o assunto políticojurídico mais relevante dos últimos tempos em matéria eleitoral, ao mexer com a estrutura de poder e de representação política, sendo merecedor de maior investimento na investigação de seus desdobramentos para o Estado Democrático.

Tendo como base tal premissa, inicia-se o estudo desse capítulo colocando-se as hipóteses de perda do mandato eletivo que constam expressamente no ordenamento jurídico nacional, relacionando as condutas que podem levar os agentes políticos eleitos à perda, suspensão de seus cargos, ou ainda, incidir em alguma inelegibilidade. Por detrás das regras criadas pela Constituição Federal, impondo limitações aos mandatos eletivos e condições que decretam sua perda, transparece, novamente, o embate dos Poderes Legislativo e Judiciário, cujo conflito em torno da matéria vem de longa data, ao menos desde a edição das normas constitucionais vigentes. Thales TÁCITo CerqueIRA, autor especializado em temas eleitorais, considera inclusive que o Legislativo protegeu-se das decisões judiciais interpretando o mecanismo estabelecido pelo art. $55 \S 3^{\circ}$., $\mathrm{CF} / 88$ de modo se que permita à Mesa da Casa Legislativa instaurar novo procedimento de contraditório, criando, assim, um verdadeiro Tribunal de Exceção $^{382}$.

\footnotetext{
${ }^{381}$ M. HERMAN SALEM CAGGIANO, A fenomenologia dos trânsfugas no cenário político-eleitoral brasileiro, cit., p. 232.

${ }^{382}$ T. T. CERQUeIRA, Fidelidade partidária e perda de mandato no Brasil: temas complexos, São Paulo, Premier Máxima, 2008, p. 27. O dispositivo citado prevê que a perda do mandato será declarada pela Mesa da Casa respectiva (nas hipóteses dos incisos III a V do mesmo artigo), assegurando a ampla defesa. A
} 
Para se aventar um suposto ativismo judicial ou de mudanças nos rumos da Corte Eleitoral, deve-se averiguar a jurisprudência formada precedentemente. No que tange ao tema da fidelidade partidária, o foco se dirige aos episódios anteriores à Consulta N. 1.398. Serão analisadas as decisões advindas do julgamento dos Mandados de Segurança de números 20.916, 20.927 e 23.405.

Para se obter o desenho da evolução jurisprudencial, após o estudo da linha seguida pela Corte Suprema em tempos passados, uma minuciosa averiguação dos votos proferidos nas decisões recentes do TSE sobre a fidelidade partidária proporcionará o quadro atual do entendimento dos Tribunais a respeito do tema. Inicia-se pela exploração do conteúdo do julgamento da Consulta N. 1.398 formulada pelo então PFL (hoje DEM), que deu ensejo à edição da Resolução N. 22.526/07 ${ }^{383}$ e culminou com as decisões do STF proferidas em sede de Mandado de Segurança, nas quais os partidos impetrantes pleitearam à Suprema Corte as vagas dos parlamentares que migraram a outros partidos durante a legislatura, lastreados no pronunciamento do TSE. Nesse ínterim, serão apresentados contundentes apontamentos feitos pelo Ministério Público Eleitoral no parecer emitido em setembro de 2007 pelo Procurador Geral da República, que é parte integrante dos autos do MS 26.603.

Deste modo, pretende-se apontar as diferentes opiniões pronunciadas, atentando para os argumentos pró e contra fidelidade, mas, acima disso, olhando para os fundamentos constitucionais prolatados e as consequências para o Estado Democrático de Direito, da devolução da cadeira ao partido pelo candidato eleito pelo povo. Essa análise propiciará diversos desdobramentos que remeterão aos conceitos estudados no primeiro capítulo: de um lado, as bases da teoria da representação política, do Estado Democrático de Direito e do Sistema Partidário; de outro, questões tangentes aos limites da interpretação jurídica, à extensão do poder normativo do TSE e à verificação da hipótese de atentado ao equilíbrio dos Poderes e às instituições democráticas.

Percebe-se o efusivo questionamento, pela doutrina, da constitucionalidade das Resoluções editadas, entre cujos desdobramentos encontram-se tentativas de afastamento ou mitigação das normas editadas pela Justiça Eleitoral, seja pela criação de uma "janela da infidelidade" (determinado período permitido para troca de

interpretação referida pelo autor assume a criação de nova instância de julgamento no Legislativo, a quem teriam sido conferidos poderes típicos do Judiciário, por força do texto constitucional mencionado.

${ }^{383}$ TSE, Consulta N. 1.398/DF e Resolução N. 22.526, rel. Min. Celso Asfor Rocha, 27.03.07, DJ 08.05.07. 
legendas sem sancionamento com a perda do mandato), seja pela edição de Decretos Legislativos, projetos de lei ou propostas de Emenda Constitucionais, normatizando a questão via Poder Legislativo. A partir da observação dos mecanismos propostos, propõese tecer uma crítica fundada na teoria constitucional, buscando demonstrar os procedimentos admitidos para inserção do instituto da fidelidade partidária no ordenamento jurídico brasileiro.

Após a publicação da Resolução do TSE que instituiu a observância à fidelidade partidária, os partidos afetados pela perda de cadeiras parlamentares iniciaram uma verdadeira corrida por sua recuperação - como era de se esperar - movimentando efusivamente a Justiça Eleitoral. Sob esse enfoque, promover-se-á a digressão teórica sobre os procedimentos para decretação da perda do cargo eletivo e da justificativa para o abandono da legenda, indicando também o rito criado pelo TSE para que os partidos proponham representação contra os "infiéis" visando à recuperação do mandato eletivo.

Como as decisões judiciais já propagam seus efeitos na prática, por meio da tentativa de recuperação das vagas parlamentares, o que se presencia nos noticiários é o retorno do embate entre o Legislativo e a Justiça Eleitoral, resgatando o debate sobre a repartição de Poderes. Tal contexto provoca a necessidade de discussão acerca da possibilidade de recusa do Presidente da Casa Legislativa de acatar diretamente a decisão judicial de empossar o suplente do parlamentar trânsfuga que teria perdido sua vaga e, paralelamente, mas em vetor antecedente, o exame da competência da Justiça Eleitoral para julgar a perda do mandato eletivo.

A metodologia estabelecida para o deslinde desse tópico requer que seja percorrido passo a passo de cada decisão, deparando-se com diversas questões que, $a$ priori, poderiam aparentar serem mais políticas do que jurídicas, porém que se demonstrarão necessárias e adequadas para capitulação dos argumentos apresentados nos votos, tais como saber as razões da migração partidária ou descobrir como os eleitores veem a troca de partidos, buscando, assim, evitar elucubrações distanciadas da realidade, do desejo popular e de conceitos pré-formulados e arraigados no âmago de cada pensador. Afinal, lida-se, aqui, com a democracia, instituto complexo e sensível, devendo verificar-se a realidade na sua prática cotidiana e apartar as emoções e sentimentos pessoais. Sabe-se que, em que grandes chances de erro incide quem generaliza a vontade de todos a partir de sua vontade, de seus valores, ideais, sentimentos ou convicções, por mais altivos que soem. 
E, certamente, essa questão enfrentada ao longo deste capítulo, tanto na observação da atividade interpretativa, quanto no estudo das consequências do ativismo judicial.

\subsection{Direitos políticos}

O elemento nuclear do debate acerca da questão da fidelidade partidária, que levou alguns partidos a provocar a manifestação do Tribunal Superior Eleitoral e do Supremo Tribunal Federal é justamente o mandato parlamentar. A disputa pela manutenção ou conquista deste revela o quantum de poder que está embutido na questão da representação e explica a acirrada disputa por cargos eletivos. Porém, é possível inferir-se diretamente que a infidelidade causa a perda do mandato? Destarte, pode-se adiantar que não há previsão expressa no ordenamento, posição que é pacífica no meio jurídico. Resta a pergunta consequente: poderia ser a infidelidade partidária instituída como causa de perda do mandato? Em qual modalidade? Seria uma inelegibilidade? Ou incidiria nas cláusulas de perda ou suspensão dos direitos políticos? Qual seria a forma adequada para sua inserção no ordenamento jurídico? É de se pontuar inicialmente, na esteira da lição de José AFONSO DA SILVA, a premência da observância do princípio democrático da plenitude dos direitos políticos, que garante o direito de votar e ser votado na sua máxima extensão possível. Qualquer restrição ao exercício desse direito fundamental deve ser considerada como exceção e assim tratada na hermenêutica constitucional. Nos termos do jurista, "a interpretação das normas constitucionais ou complementares relativas aos direitos políticos deve tender à maior compreensão do princípio, deve dirigir-se ao favorecimento do direito de votar e de ser votado, enquanto as regras de privação e restrição hão de entender-se nos limites mais estreitos de sua expressão verbal, segundo as boas regras de hermenêutica." ${ }^{384}$

Tais questionamentos e observações fundamentam o estudo dos direitos políticos, abrangendo as causas de perda do mandato eletivo, tendo em vista, inclusive, a tentativa parlamentar de inclusão da infidelidade partidária como cláusula de inelegibilidade por meio de lei complementar. Em suma, a averiguação da posição assumida por nossas Cortes diante do assunto em tela denota ser fundamental a compreensão das hipóteses estabelecidas na Constituição e legislação eleitoral referentes à perda do mandato. Tais proposições estão inseridas em um contexto mais amplo: o dos

${ }^{384}$ J. AfONSO DA SILva, Curso de direito constitucional positivo, 27ª . ed., São Paulo, Malheiros, 2006, p. 382. 
direitos políticos, que são direitos fundamentais presentes na Constituição Federal no Capítulo IV, título II.

A doutrina conceitua os direitos políticos como um conjunto de normas previstas na Constituição, que estabelecem o modo de exercício da soberania popular e que são classificadas, para fins de estudo, em direitos políticos positivos e negativos. Os primeiros, nos termos de J. AFONSO DA SILVA ${ }^{385}$, tratam do direito subjetivo de participação popular no processo político e acesso aos órgãos de governo, consequência da aquisição da cidadania, decorrentes do dispositivo contido no parágrafo único do artigo primeiro da Lei Magna, que institui o princípio democrático ao prever que todo poder emana do povo. Encontram-se no rol dos direitos políticos positivos o direito de sufrágio, as condições de alistabilidade e elegibilidade, a iniciativa popular de lei, a ação popular e a organização de partidos políticos e a participação nesses do cidadão e a participação desses no sistema político eleitoral ${ }^{386}$.

O núcleo dos direitos políticos se revela no direito de sufrágio, que, por sua vez, traduz-se nos direitos do cidadão de elegibilidade, de escolha do representante do povo e de participação na organização do poder governamental. Trata-se de conceito mais abrangente que o direito de votar, pois, como lembra J. Afonso DA SILVA, o voto é o exercício do direito de sufrágio ${ }^{387}$. Seu principal caractere, a universalidade, compõe um dos princípios basilares da democracia política, ao igualar a identidade entre governantes e governados.

A doutrina apresenta o direito de sufrágio em duas facetas: a capacidade eleitoral ativa, que se traduz no direito de eleger ou alistabilidade, e; a capacidade eleitoral passiva, que é o direito de ser eleito ou elegibilidade. A primeira designa a participação do cidadão no regime democrático, que se processa pela escolha de seus representantes, por meio do exercício do direito de sufrágio em eleições, plebiscitos e referendos. Requer a Constituição Federal vigente, em seu art. 14, que o eleitor, para que assim se possa considerar, seja de nacionalidade brasileira, possua idade mínima de dezesseis anos e efetue o procedimento administrativo de alistamento perante a Justiça Eleitoral e não esteja conscrito em serviço militar obrigatório.

De outro lado, a capacidade eleitoral passiva guarda relação com a elegibilidade, ou seja, a capacidade de ser eleito, pelo pleito de mandatos políticos, via

\footnotetext{
385 J. AfONSO DA SILVA, Curso de direito constitucional positivo, cit., p. 348.

${ }^{386}$ A. DE MORAES, Direito Constitucional, 23ª ed., São Paulo, Atlas, 2008, p. 225-226.

387 J. AFOnSo DA SILVA, Curso de direito constitucional positivo, cit., p. 349 e 357: "O voto é o ato político que materializa, na prática, o direito público subjetivo de sufrágio."
} 
eleição. É característica de um regime democrático, a universalidade tanto da elegibilidade quanto da alistabilidade. No sistema político pátrio, que segue a tendência das democracias ocidentais, há certa limitação à elegibilidade, não sendo suficiente a capacidade eleitoral ativa para ter-se a passiva. Há uma série de condições postas no parágrafo $3^{\circ}$. do art. 14 da $\mathrm{CF} / 88$, que, de modo resumido, consistem em: possuir nacionalidade brasileira ou ser português equiparado ${ }^{388}$; ter pleno exercício dos direitos políticos; estar alistado eleitoralmente; possuir domicílio eleitoral na circunscrição pela qual se candidata, alcançar idade mínima ${ }^{389}$, e; estar filiado em partido político ${ }^{390}$.

Alerta J. AFONSO DA SILVA que, para plena aptidão ao pleito eletivo não basta ao cidadão preencher as condições de elegibilidade, mas igualmente não incidir em nenhuma das inelegibilidades ${ }^{391}$, cujas regras, na classificação doutrinária, compõem os direitos políticos negativos, ao lado das normas sobre a privação dos direitos políticos ${ }^{392}$. São, portanto, os direitos políticos ditos negativos as previsões normatizadoras que limitam a capacidade eleitoral passiva, restringindo o acesso do cidadão ao mandato político.

As inelegibilidades são obstáculos impostos constitucionalmente ${ }^{393} \mathrm{e}$ legalmente, que visam "proteger a probidade administrativa, a moralidade para o exercício do mandato (...), a normalidade e legitimidade das eleições, contra a influência do poder econômico ou o abuso do exercício de função, cargo ou emprego na administração direta ou indireta" ${ }^{394}$. Na verificação de alguma de suas hipóteses, resultam na exclusão da capacidade eleitoral passiva. Nota-se que há, portanto, um fundamento ético que traz a correlação com a democracia, "não podendo ser entendido como um moralismo desgarrado da base democrática do regime que se instaure". É o que adverte com propriedade J. AFONSO DA SILVA 395 .

São absolutamente inelegíveis para qualquer mandato eletivo os inalistáveis (os estrangeiros, os privados de seus direitos políticos e os conscritos) e os

\footnotetext{
${ }^{388}$ Para alguns cargos, como os de Presidente e Vice-Presidente da República, exige a Constituição, em seu art. $12, \S 3^{\circ}$., a condição de brasileiro nato. Constituição Federal da República do Brasil de 05.10.88.

${ }^{389}$ Conforme esclarecido na Res. N. 14.371, deve-se atender à idade mínima como requisito de elegibilidade na data do certame eleitoral, quando o eleitor escolhe seu candidato e não do alistamento ou do registro. TSE, Res. N. 14.371, rel. Min. Marco Aurélio, 26.05.94, DJ 30.05.94.

${ }^{390}$ A impossibilidade de pleitear mandato político sem prévia filiação partidária decorre de norma constante do art. 17, Constituição Federal da República do Brasil de 05.10.88.

391 J. AfONSO DA SILVA, Curso de direito constitucional positivo, cit., p. 366-367.

392 A. DE MORAES, Direito Constitucional, cit., p. 232-261.

393 As previsões de inelegibilidade constam dos $\$ \S 4^{\circ}$. a $7^{\circ}$. do art. 14, da Constituição Federal da República do Brasil de 05.10.88. e do art. $1^{\circ}$. da Lei Complementar 64/90.

${ }_{394}$ Art. 14, § $9^{\circ}$., Constituição Federal da República do Brasil de 05.10.88.

395 J. AFONSO DA SILVA, Curso de direito constitucional positivo, cit., p. 388.
} 
analfabetos $^{396}$. Tais condições referem-se ao sujeito do qual se analisa a capacidade passiva e, pelo caráter de exceção, somente podem ser ditadas em nível constitucional ${ }^{397}$. Há também as inelegibilidades relativas que se adstringem a certos pleitos ou cargos, observadas determinadas situações no momento da eleição. A inelegibilidade relativa não decorre da inexistência ou perda da capacidade eleitoral passiva, mas apenas impede seu exercício em circunstâncias especiais. Decorrem as hipóteses de inelegibilidade relativa de: motivos funcionais, casamento ou parentesco, oficialato, e previsões decorrentes de lei complementar.

Considerando-se a profusão de decisões emanadas pelo TSE tendo por objeto as inelegibilidades relativas, estas serão estudadas com maior detalhe. Assim, em referência aos motivos funcionais, analisa-se separadamente a questão da reeleição e a da candidatura para outros cargos. Quanto à reeleição, observa-se que, em junho de 1997, com o advento da Emenda Constitucional $\mathrm{N}^{\circ} .16$, foi introduzida pioneiramente no ordenamento pátrio a possibilidade de reeleição para o Chefe do Executivo nos níveis da Federação ${ }^{398}$. Até mesmo a Constituição Cidadã de 1988 previa, em seu texto original, a proibição à condução de novo mandato sucessivo, o que se justificava, à época, com a necessidade de evitar o personalismo e a perpetuidade do Chefe do Executivo, à luz da alternância no poder, princípio fundamental da democracia. Alegava-se, por vezes, impedir igualmente a cooptação da máquina estatal para uso em campanha eleitoral. Quando da edição da mencionada Emenda Constitucional, surgiram posicionamentos de juristas favoráveis a reeleição ${ }^{399}$, em apoio à nova redação dada ao $\S 5^{\circ}$. do art. 14 da Constituição vigente, que prevê a possibilidade de reeleição "para um único período subsequente", vedando o terceiro mandato sucessivo e mantendo-se, deste modo, a chamada inelegibilidade relativa por motivos funcionais para o mesmo cargo ${ }^{400}$. O tema se reveste de atual importância, pois tramitou, no Congresso Nacional, no ano de 2009, a um ano das

${ }^{396}$ Art. 14, § 4 $4^{\circ}$., Constituição Federal da República do Brasil de 05.10.88.

397 A. DE MoRAES, Direito Constitucional, cit., p. 233. J. AFOnSO DA Silva, Curso de direito constitucional positivo, cit., p. 390.

398 TSE, Res. N. 19.952, DJ 21.10.97. A confirmação de que ao Vice-Chefe do Executivo caberia a plena elegibilidade quando da reeleição aos mesmos cargos veio com a Res. N. 19.952/97.

${ }^{399}$ V., A. DE MORAES, Direito Constitucional, cit., p. 236. Para o jurista, "a reeleição é democrática, e deve ser implementada, juntamente com a concessão de maiores mecanismos e instrumentos para a Justiça eleitoral e o Ministério Público coibirem o uso da máquina administrativa”. Ressalta o autor que salientava desde a primeira edição de sua obra (1996), que "não havia o que justificasse a vedação à reeleição".

${ }^{400}$ Em março de 1998 o TSE editou a Res. N. 20.114, que reafirmou a impossibilidade do "exercício do cargo em três períodos consecutivos". Assim também se observou nas eleições paulistas de 2006 quando o governador José Geraldo Alckmin Filho, tendo sido Vice-Governador eleito no mandato 1999-2002 e assumido a Chefia do Executivo com o falecimento do então Governador Mário Covas em março de 2001, pode reeleger-se para o mandato 2003-2006, mas seria inelegível para o seguinte pleito. TSE, Res. N. 20.114, rel. Min. Neri da Silveira, 10.03.98, DJ 03.06.98. 
eleições presidenciais, a tentativa aprovação de projeto de emenda constitucional tendente a aprovar o terceiro mandato para o Presidente da República, por iniciativa de alguns parlamentares da base aliada ao governo. Nesse sentido, significante a comparação com dispositivo similar da Constituição portuguesa de 1976, que veda expressamente o terceiro mandato consecutivo, permitindo apenas dois sucessivos para o mesmo cargo ${ }^{401}$.

Necessário, igualmente, atentar-se para $o$ fato de que a desincompatibilização é norma exigida para o candidato que pleiteia outro cargo e não para o que procura a recondução ${ }^{402}$. Assim se pronunciou a mais alta Corte Eleitoral ${ }^{403}$, que, ademais, frisou ser somente em nível constitucional e de forma expressa que, em se tratando de caso de elegibilidade, poderia ser estabelecida a necessidade de desincompatibilização para os ocupantes de mesmo cargo, cuja hipótese não consta do texto atual. Demonstrou-se que a ausência de norma restritiva não permite interpretação extensiva, posição que veio a ser confirmada pela Corte Suprema ${ }^{404}$.

A mencionada desincompatibilização, consistente na renúncia ao mandato do Chefe do Executivo até seis meses antes do certame eleitoral, configura outra inelegibilidade relativa, por motivo funcional. A norma se aplica somente ao Chefe do Executivo e não se estende aos Vices, que não tenham sucedido ou substituído o titular em qualquer momento $^{405}$.

Completam as inelegibilidades relativas as denominadas inelegibilidades reflexas, cujo objetivo é impedir a eleição do cônjuge e parentes do titular do mandato eletivo no território de sua circunscrição nas três esferas de federativas, evitando-se a

\footnotetext{
${ }^{401}$ Inúmeras foram as situações em que a Corte Eleitoral foi instada a se manifestar, diante das dúvidas advindas com a EC-16/97. Tome-se como exemplo a Consulta N. 900 e Res. N. 21.438 do TSE, que afirmou que "ex-prefeito que cumpriu dois mandatos consecutivos, ainda que descompatibilizado tempestivamente, não poderá se candidatar a Vice-Prefeito do mesmo município na eleição subsequente". TSE, Res. N. 21.438, DJ 29.09.03. Interessante, nesse sentido, os comentários de A. DE MORAES, sobre a inelegibilidade descrita, ressaltando que "não há o que se falar na impossibilidade de interpretar-se extensivamente norma restritiva de direito, mas na aplicação correta de regra de hermenêutica, a revelar e definir o exato sentido da norma, de molde a impedir que, por via indireta, viesse ele a frustrar-se, pois se acaso o novo Prefeito renunciasse e o vice assumisse a titularidade do Executivo, estar-se-ia burlando a regra que vedava a reeleição, pois estaria exercendo dois mandatos de Prefeito sucessivamente". A. DE MoRAES, Direito Constitucional, cit., p. 239.

${ }^{402}$ M. G. FERREIRA FILHO critica duramente a lógica do sistema de desincompatibilização (à qual insere no conceito de irreelegibilidade, por ser considerada uma espécie de inelegiblidade), mostrando que o Chefe do Executivo que procura a recondução não sofre a necessidade do afastamento, mas se pleiteia, e.g., um cargo parlamentar (outro cargo), deve desincompatibilizar-se. A ilogicidade, para o mestre, reside na análise da finalidade do instituto, qual seja, a de evitar o abuso no uso da máquina para eleição, o que deveria valer tanto para reeleição, quanto para a busca de um novo cargo eletivo. M. G. FERREIRA FILHO, Curso de Direito Constitucional, 34 ${ }^{\text {a }}$ ed., São Paulo, Saraiva, 2008, p. 119.

${ }^{403}$ TSE, Res. N. 19.952 (Consulta N. 327/97-DF), DJ 21.10.97.

${ }^{404}$ STF, Pleno, ADI N. 1.805, rel. Min. Néri da Silveira, 26.03.98. No julgamento da ADIN, o STF vedou expressamente qualquer interpretação que estabeleça restrição de direitos políticos não previstos expressamente na Constituição.

${ }^{405}$ TSE, Res. N. 19.507, rel. Min. Ilmar Galvão, 16.04.96, DJ 10.05.96.
} 
formação de oligarquias familiares. A Constituição ainda prescreve que o militar alistável é elegível se contar com menos de dez anos de serviço e se afastar da atividade ou, se contar com período superior a dez anos, passar para a inatividade no ato da diplomação.

Por fim, conforme ensina AlEXANDRE DE MORAES, outras previsões de inelegibilidades relativas foram constitucionalmente autorizadas para disposição mediante lei complementar ${ }^{406}$, com a finalidade de preservar a moralidade para o exercício do mandato e a probidade administrativa, contra abusos do poder econômico, todos visando proteger fundamentos do regime democrático. J. AFONSO DA SILVA compartilha da assertiva quanto à eficácia das normas sobre inelegibilidades, frisando, todavia, que estas "por serem restritivas de direitos fundamentais (direitos à elegibilidade), é que a técnica sempre recomendou que fossem disciplinadas inteiramente em dispositivos constitucionais" ${ }^{407}$, adicionando que, ao contrário da tradição constitucional pátria, a Carta de 1988 relegou à lei complementar a possibilidade de criação de outras hipóteses sem definir limites claros, o que implicou, por vezes em "excessivo casuísmo", nos termos do autor, opinião com a qual concorda MANOEL GonçAlves FerReira FilHo. Para este, a norma do art. $14 \S 9^{\circ}$, em que pese a permissão dada à lei complementar para ampliar os casos de inelegibilidade, o faz de maneira condicionada às finalidades que determina e "em campos de atividade que indica”, implicando tal fato o caráter excepcional da autorização, o que retira qualquer eventual arbitrariedade proposta via lei complementar ${ }^{408}$.

Importante conhecer a posição doutrinária como parâmetro para o exame das iniciativas de adição da infidelidade partidária como causa de perda do mandato parlamentar ou de inelegibilidade. Assim destaca M. Herman Salem CagGiano, que, em 2007, três foram os projetos de Emenda Constitucional e seis os projetos de lei

\footnotetext{
$406 \mathrm{O}$ art. $1^{\text {o, }}$ inciso I, da Lei Complementar 64/90, em suas alíneas de "a" a "i" prevê as seguintes de inelegibilidades, de forma resumida: Os inalistáveis e os analfabetos, repetindo o texto constitucional; os parlamentares que tiveram os mandatos "cassados" por exercer atividade incompatível com o cargo ou por quebra de decoro (inelegibilidade durante o período remanescente do mandato para o qual foram eleitos e nos oito anos subsequentes ao término da legislatura), em atenção ao princípio da moralidade e em referência aos incisos I e II do art. 55 CF/88; aqueles que foram condenados por abuso de poder econômico (inelegibilidade para a eleição na qual concorrem ou tenham sido diplomados, bem como para as que se realizarem nos três anos seguintes); os condenados por crimes contra a economia popular, a fé pública, a administração pública, o patrimônio público, o mercado financeiro, por tráfico de entorpecentes e por crimes eleitorais (inelegíveis por 3 anos após o cumprimento da pena), analisando a probidade e vida passada do candidato; aqueles cujas contas relativas ao exercício anterior de cargo ou função pública foram rejeitadas pelos Tribunais de Contas (inelegíveis para as eleições que se realizarem nos 5 (cinco) anos seguintes, contados a partir da data da decisão), valorizando, igualmente, a probidade; outras disposições encontradas às alíneas "c" "f" e "i" do referido artigo.

407 J. AFONSO DA SILVA, Curso de direito constitucional positivo, cit., p. 389.

${ }^{408}$ M. G. FERREIRA FILHO, Curso de Direito Constitucional, cit., p. 121.
} 
(complementar e ordinária) ${ }^{409}$, que serão objeto de análise mais detalhada ao longo desse capítulo quanto à forma de introdução da norma sancionatória no ordenamento jurídico.

Fechando o quadro dos direitos políticos negativos, têm-se constitucionalmente previstos no art. 15 os modos de privação destes, o que pode ocorrer de maneira definitiva ou temporária, provocando a perda da cidadania. No primeiro caso, a doutrina - pois a Constituição não faz a distinção ${ }^{410}$ - observando a natureza dos institutos, proclama se estar diante das hipóteses de perda dos direitos políticos e consequente perda, em regra ${ }^{411}$, do mandato eletivo. São essas: (i) o cancelamento da naturalização por sentença transitada em julgado (art. 15, I); (ii) a recusa de cumprir obrigação a todos imposta ou prestação alternativa, nos termos do art. $5^{\circ}$., VIII - escusa de consciência (art. 15., IV); (iii) perda da nacionalidade do brasileiro (art. 12, $\S^{\circ}$. ., I e II). Todas se revestem do caráter da definitividade ${ }^{412}$, ao contrário dos casos de suspensão ${ }^{413}$, que privam temporariamente os direitos políticos por: (i) incapacidade civil absoluta (art. 15, II), (ii) condenação criminal transitada em julgado, enquanto durarem seus efeitos; (iii) improbidade administrativa, nos termos do art. $37, \S 4^{\circ}$. (art. 15, V).

\footnotetext{
${ }^{409}$ Para referência quanto às PEC e PLP mencionados, v. M. HERMAN SALEM CAGGIANO, A fenomenologia dos trânsfugas no cenário político-eleitoral brasileiro, cit., p. 241.

${ }^{410}$ Porém estabelece no caput do art. 15 a vedação à cassação dos direitos políticos. Constituição Federal da República do Brasil de 05.10.88.

${ }^{411}$ A regra geral aparece no art. 55, IV, CF/88. A exceção à regra se encontra no art. 55, inciso VI e $\S 2^{\circ}$. $\mathrm{CF} / 88$, que preveem aos Deputados Federais e Senadores a perda - não automática - do mandato, impedindo, ademais, enquanto durarem seus efeitos, a disputa por novo pleito, nos casos de condenação criminal em sentença transitada em julgado. Trata-se de exceção absoluta compatível com as regras de hermenêutica, pois a citada norma se reveste de caráter especial em face da norma do art. 15, III, CF/88, de cunho genérico. A perda do mandato não é automaticamente decorrente da privação dos direitos políticos, pois é decidida pela Câmara dos Deputados ou Senado Federal, assegurada a ampla defesa, nos termos do $\S 2^{\circ}$. do art. $55 \mathrm{CF} / 88$, que abre a possibilidade de rediscussão do mérito decidido em esfera jurisdicional e cria a possibilidade de exercício de mandato eletivo por aquele que teve privado seus direitos políticos. Entende T. T. CERQUEIRA que a previsão excepcional pode ser estendida às esferas estaduais ou distritais se previstas na Constituição Estadual. $\mathrm{O}$ autor coloca ainda uma segunda exceção à regra geral supracitada, de caráter relativo, consistente na perda do mandato do Vereador que incide em crime de responsabilidade, cuja decisão transitada em julgado é comunicada ao Presidente da Câmara que deverá declarar a extinção do mandato na primeira sessão. A relatividade, segundo o autor, encontra-se na possibilidade do Vereador suplente, o Prefeito ou o Ministério Público requererem, por via jurisdicional, a extinção do mandato em caso de recusa do Presidente da Câmara Municipal (art. $8^{\circ}$., § $2^{\circ}$., DL 201/67), que estará sujeito às penas aplicadas ao ato de improbidade administrativa, perdendo o cargo e tendo seus direitos políticos suspensos. Cf. A. DE MORAES, Direito Constitucional, cit., p. 254-261; T. T. CERQUEIRA, Fidelidade partidária e perda de mandato no Brasil: temas complexos, cit., p. 28-35.

412 J. AFONSO DA SILVA opina pela inclusão da escusa de consciência como hipótese de perda e não suspensão - ao contrário do texto da Lei N. 8.239/91, mostrando, acertadamente, que a recuperação prevista em lei dos direitos políticos nessa hipótese é meramente possibilidade de reaquisição dos direitos perdidos e não se processa de forma automática, por cessação de causa de privação, característica dos casos de suspensão. Curso de direito constitucional positivo, cit., p. 387-390.

413 M. G. FERREIRA FILHO atenta para a impropriedade da expressão "suspensão", preferindo o termo "privação temporária" a esta, pois sua recuperação se dá de forma automática, pelo "desaparecimento de seu fundamento ou pelo decurso de prazo". Curso de Direito Constitucional, cit., p. 117-118.
} 
Em conclusão, resumem-se aqui os principais pontos atinentes, ainda que indiretamente, ao problema da troca interpartidária, a saber:

I- As inelegibilidades e as causas de perda ou suspensão dos direitos políticos e consequente perda do mandato eletivo estão previstas de forma taxativa tanto no texto constitucional como, de maneira infraconstitucional, em lei complementar. Seja nas inelegibilidades, seja nas causas de perda dos direitos políticos, não há qualquer referência à infidelidade ${ }^{414}$, nem sanção pela troca de partidos a qualquer tempo;

II- A doutrina critica a possibilidade aberta pelo constituinte de 1988 de relegar hipóteses de inelegibilidades a normas infraconstitucionais. Tendo como objeto direitos fundamentais, a matéria da disposição e restrição dos direitos políticos deveria ser atribuída à Constituição tão somente. Tal como previsto no ordenamento vigente, abrem-se as portas para eventuais arbitrariedades do legislador infraconstitucional;

III- Os direitos políticos ditos negativos - inelegibilidades e privações dos direitos políticos - se prestam a resguardar institutos, princípios e valores afins com o regime democrático, dentre os quais se enfatiza a moralidade: seja no exercício do mandato eletivo, seja quanto ao decoro e a probidade administrativa; igualmente, procura-se proteger as eleições, em atenção aos princípios democráticos da igualdade, legitimidade, afastando-se o abuso de poder.

Sendo essas as principais conclusões a respeito dos direitos políticos que guardam relação com eventual sanção de perda do mandato durante a legislatura, passa-se, então, ao exame das decisões e casos concretos de perda de mandato.

\subsection{Decisões precedentes do STF sobre a fidelidade partidária}

O debate ministerial sobre a quebra do princípio da fidelidade partidária e a consequente perda do mandato parlamentar não é de todo novo na mais alta corte judiciária. Por ocasião dos Mandados de Segurança 20.916 e 20.927, ambos de 11/10/89 e

414 Note-se que o art. 17, $\S 1^{\circ}$. da Constituição Federal da República do Brasil de 05.10.88. coloca a fidelidade como assunto interno aos partidos, a ser tratado em seus estatutos. 
23.405 de 22/03/04, o Supremo, em contextos histórico e político diferentes, enfrentou a questão. A análise dos votos proferidos nos referidos julgamentos demonstra que já havia dissidência no entendimento da Corte quanto aos efeitos da troca de partido pelo parlamentar no curso do mandato eletivo, denotando que a polêmica não é recente, mas vinha, ao menos, desde o advento da Constituição vigente.

O estudo da evolução constitucional do assunto em pauta mostra ter havido alternância entre a sanção à infidelidade e a não punição pela troca partidária. Observa-se, nos momentos iniciais da história dos partidos brasileiros, certa fraqueza e falta de institucionalização, o que implica a irrelevância da eventual troca partidária que, inclusive, em termos quantitativos, demonstrava-se pouco expressiva em seus primórdios. Talvez por essa razão, desde a Constituição Imperial até a Constituição de 1946, não se encontra menção ao instituto da fidelidade partidária no ordenamento. $\mathrm{O}$ fato novel veio com a Constituição Federal de 24 de janeiro de 1967, que, em seu art. 149, introduziu no âmbito constitucional a disciplina partidária.

Encontra-se pioneiramente em textos constitucionais a inclusão do princípio da fidelidade partidária em 1969, por força da Emenda Constitucional No. 1, estabeleceu o princípio da fidelidade partidária, consistente na perda do mandato, a ser decretada pela Justiça Eleitoral e em processo contencioso, do parlamentar que deixasse o partido sob o qual se elegera, assegurada a ampla defesa e culminando com a declaração pela Mesa da Câmara ${ }^{415}$. A infidelidade como causa de perda do mandato permaneceu por mais de quinze anos no ordenamento, quando, com o advento da Emenda Constitucional 25/85, foi revogada a previsão do art. 35 que enumerava, como um dos motivos de perda do mandato, a troca de partido. O constituinte de 1988 optou por manter a regra vigente

\footnotetext{
${ }^{415}$ Art. 152 da EC-1/69: "Perderá o mandato no Senado Federal, na Câmara dos Deputados, nas Assembléias Legislativas e nas Câmaras Municipais quem, por atitude ou pelo voto se opuser às diretrizes legitimamente estabelecidas pelos órgãos de direção partidária ou deixar o partido sob cuja legenda foi eleito". Posteriormente, a Emenda Constitucional No. 11, de 13 de outubro de 1978, abrandou a sanção à fidelidade partidária, introduzindo uma ressalva para aqueles que se desligassem do grêmio pelo qual foram eleitos para participar da formação de novo partido político: "Perderá o mandato no Senado Federal, na Câmara dos Deputados, nas Assembléias Legislativas e nas Câmaras Municipais quem, por atitudes ou pelo voto, se opuser às diretrizes legitimamente estabelecidas pelos órgãos de direção partidária ou deixar o Partido sob cuja legenda foi eleito, salvo se para participar, como fundador, da constituição de novo Partido”. O art. $2^{\circ}$. da citada Emenda, conforme lembra o Ministro Aldir Passarinho, estipulou que, aquele que trocasse de partido dentro do lapso temporal de um ano, não seria sancionado com a perda do mandato: "Para os efeitos do disposto do $\S 5^{\circ}$. e $6^{\circ}$. do art. 152 da Constituição Federal, não configura a infidelidade partidária a filiação de Senador, Deputado Federal, Deputado Estadual e Vereador a partido já constituído, dentro do prazo de um ano a contar da vigência desta Emenda." Cita-se como beneficiados imediatos da referida alteração o então Senador Tancredo Neves e o Deputado Magalhães Pinto, que abandonaram seu partido de eleição para fundarem um novo partido: o Partido Popular.
} 
desde 1985. Não propôs nenhuma sanção jurídica, tampouco qualquer outra consequência, àquele que trocasse de partido, mantendo inócuo o princípio da fidelidade partidária.

\subsubsection{MS 23.405/04}

A última oportunidade em que o Supremo Tribunal se manifestou acerca da questão da fidelidade partidária - antes do célebre julgamento divisor de águas de 2007 - fora na apreciação ao MS 23.405 no ano de 2004.

Fundamentando-se no silêncio do texto constitucional e da legislação infraconstitucional, o relator do MS 23.405/04, Ministro Gilmar Mendes, proferiu, com brevidade, seu voto, afirmando que "é certo que a Constituição não fornece elementos para que se provoque o resultado pretendido pelo requerente". No processo em tela, o impetrante, Ney Moura Teles, pediu a segurança contra ato do Presidente da Câmara dos Deputados, que deferira os requerimentos formulados por três Deputados Federais, determinando que fossem alteradas nos registros parlamentares as filiações partidárias dos congressistas. Estes, tendo sido eleitos para o período de 1998-2002 por coligação formada pelo PMDB e PL (entre outros partidos) migraram em fevereiro de 1999 para o PSDB, partido que elegera pela segunda vez consecutiva o Presidente da República. O fundamento do impetrante residia no entendimento de que, com base no princípio representativo e no sistema eleitoral proporcional, os parlamentares trânsfugas teriam perdido o direito de exercício do mandato e seus cargos deveriam ser declarados vagos. Logo, sendo o impetrante o terceiro suplente da coligação pela qual os migrantes se elegeram, teria direito à posse no cargo de Deputado Federal, direito este, que estaria sendo obstado pela autoridade coatora, no entender do requerente.

Apesar da perda do objeto do writ, uma vez que o julgamento ocorreu dois anos após o término da legislatura em questão, o Ministro relator enfrentou a discussão no que diz respeito à perda do mandato perante a inobservância do princípio da fidelidade partidária. De pronto, arrolou os incisos do art. 55 da $\mathrm{CF} / 88$, para apontar a ausência de hipótese permissiva à sanção do parlamentar diante de infidelidade. Referiu-se o relator, no mesmo sentido, ao voto proferido pelo Ministro Moreira Alves, no julgamento do MS 20.927, transcrevendo o excerto no qual o ilustre Ministro opina pela "inaplicabilidade do princípio da fidelidade partidária aos parlamentares empossados (...)", diante do silêncio da Constituição Federal e da lei, invocando a vontade do constituinte de 
não preservar a sanção jurídica da perda do mandato, como forma de obstar a diminuição da representatividade do partido abandonado pelo parlamentar trânsfuga. Todavia, já era possível se notar, à época, a ponderação de valores e o uso dos princípios. A intenção do constituinte de não positivar a sanção foi aspecto mais valorado do que a alteração da representatividade no parlamento decorrente das trocas de legenda. Um maior peso foi atribuído à interpretação histórica e axiológica, além da gramatical. Apesar disso, não foi negada a relevância da representatividade dos partidos no parlamento, bem como os efeitos danosos de sua constante variação advinda das migrações partidárias. Tanto assim que, embora julgando prejudicada a impetração, não perdeu o Ministro Gilmar Mendes a oportunidade de expor sua opinião quanto ao instituto, tecendo críticas à troca de partidos "por parlamentares eleitos sob o regime da proporcionalidade", considerando-a prejudicial ao "desenvolvimento e continuidade do sistema eleitoral e do próprio sistema democrático (...)". De outra face, o Ministro reafirmou as palavras do Ministro Moreira Alves, certificando a inexistência de elementos no texto constitucional a dar guarida à pretensão do requerente. O Tribunal, de forma unânime, julgou prejudicado o mandamus, de modo que não se travou extenso debate sobre o tema nessa oportunidade.

\subsubsection{MS 20.927/89}

Se a decisão proferida pelo STF em 2004 não ofereceu maiores debates sobre a perda do mandato decorrente de infidelidade, o inverso se observa no acórdão proferido em sede de Mandado de Segurança (MS 20.927) em 11 de outubro de 1989, cuja ementa revela o ponto crucial da discussão:

"MANDADO DE SEGURANÇA. FIDELIDADE PARTIDÁRIA. SUPLENTE DE DEPUTADO FEDERAL. Em que pese o princípio da representação proporcional e a representação parlamentar Federal por intermédio dos partidos políticos, não perde a condição de suplente o candidato diplomado pela Justiça Eleitoral ${ }^{416}$ que, posteriormente, se desvincula do partido ou aliança partidária pelo qual se elegeu. A inaplicabilidade do princípio da fidelidade partidária aos parlamentares empossados se estende, no silêncio da Constituição e da lei, aos respectivos suplentes. Mandado de segurança indeferido."417

\footnotetext{
${ }^{416}$ Diplomação é o ato pelo qual a Justiça Eleitoral atesta quem são os eleitos e respectivos suplentes com a entrega do diploma assinado. Com a diplomação os eleitos se habilitam a exercer o mandato que postularam, mesmo que haja recurso pendente de julgamento, pelo qual se impugna exatamente a diplomação. O recurso de diplomação é o instrumento hábil à desconstituição dos diplomas expedidos pela Justiça Eleitoral, sendo cabível em razão de inelegibilidade, erros no cálculo do quociente eleitoral e partidário, dentre outras hipóteses previstas no art. 262 do Código Eleitoral, disponível (on line) in www.tse.gov.br., [03.08.09].

${ }^{417}$ STF, Pleno, MS 20.927-DF, rel. Min. Moreira Alves, 11.10.89, DJ 15.04.94.
} 
A impetração contra o ato do Presidente da Câmara dos Deputados, que deu posse ao segundo suplente de Coligação partidária que havia trocado de partido (do PFL para o PL) durante a legislatura, fundamenta-se na tese de perda da condição de suplente da coligação pelo empossado quando da quebra do vínculo partidário pelo qual se elegeu. O impetrante alegou precedente da Corte no RE 99.884-5 de 18 de outubro de $1983^{418}$, que trouxe em seu relatório a decisão proferida em primeira instância e confirmada pelo Tribunal de Justiça do Espírito Santo, cuja ementa diz: "O desligamento regular de partido político rompe o vínculo partidário do filiado, acarretando-lhe, inclusive, a perda da condição de Suplente de cargo eletivo." ${ }^{419}$

Ora, é de se notar que, à época deste acórdão (1983), a fidelidade partidária estava positivada em nosso ordenamento, sendo que - conforme anteriormente relatado - somente em 1985, por força da Emenda Constitucional No. 25, a infidelidade foi excluída como causa da perda de mandato eletivo. Logo, na data do julgamento do MS 20.927/89, não havia qualquer previsão constitucional que permitisse sanção ao infiel.

Com base na ausência de norma proibindo as trocas partidárias, a autoridade impetrada (Presidente da Câmara dos Deputados) sustentou primeiramente sua

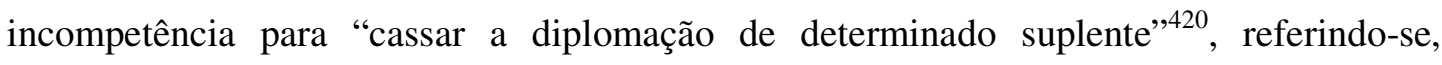
ademais, à impossibilidade de colocar no exercício do mandato quem obteve votação nominal inferior, em desrespeito à vontade do eleitor. Rememorou o conteúdo da Resolução N. 13.605 do TSE, de 02/04/87, que previa:

\footnotetext{
“Ocorrendo vaga, será convocado o suplente, na ordem rigorosa da votação nominal, e de acordo com sua classificação (art. 50, parágrafo único, Res. 13.266/86), passando a exercer o mandato sob a legenda do partido no qual se encontra filiado, mesmo que com isso se diminua a representação de outro, integrante da mesma coligação, mas respeitado o princípio da votação majoritária e a vontade do eleitor.” (grifos nossos)
}

\footnotetext{
${ }^{418}$ O não conhecimento do recurso decorreu da perda de seu objeto com o término da legislatura municipal anteriormente ao julgamento. Pretendia-se discutir a perda do direito de suplência daquele que se desligara do partido pelo qual se elegeu. Disse o Ministro relator Oscar Corrêa: "desligado do partido, não há pretender se mantenha a condição de seu representante, contradição evidente nos próprios termos, em regime partidário como o nosso". Note-se que não há no voto do relator referência direta à previsão expressa de sanção à infidelidade partidária presente no ordenamento vigente à época. Todavia, fala o Ministro em "regime partidário", em clara referência à vinculação ao partido então estabelecida constitucionalmente. Tal regime, conforme já visto, sofreria mudanças com a EC-25/85. STF, 1ª Turma, RE 99.884-5-ES, rel. Min. Oscar Corrêa, 18.10.83, DJ 18.11.83.

${ }^{419}$ STF, $1^{\text {a }}$. Turma, RE 99.884-5-ES, rel. Min. Oscar Corrêa, 18.10.83, DJ 18.11.83.

${ }^{420}$ Cf. alegações de defesa no MS 20.927-DF. STF, Pleno, MS 20.927-DF, rel. Min. Moreira Alves, 11.10.89, DJ 15.04.94.
} 
A ementa é cristalina ao determinar que passe a exercer o mandato o suplente "sob a legenda do partido no qual se encontra filiado", mostrando a validade do entendimento de que não se considera, para fins de preenchimento de vaga aberta, o partido pelo qual o suplente se elegeu e, por conseguinte, a eventualidade de mudança de partido. A lógica dos argumentos do Presidente da Câmara dos Deputados se fundou no "fim do princípio da fidelidade partidária" e na seguinte dedução: se os parlamentares que migram de partido não sofrem sanção, o mesmo se opera aos suplentes.

De sua parte, o Procurador-Geral da República adicionou um elemento inédito ao debate: a jurisprudência eleitoral formada até então tratava da infidelidade dos titulares de cargo eletivo ${ }^{421}$. O Procurador frisou haver "nítida distinção jurídica" na situação dos suplentes, que não detinham mandato eletivo, mas apenas uma expectativa de direito ao mandato, sob condição suspensiva. Fundando seu parecer no art. 112 do Código Eleitoral $^{422}$, entendeu ser indispensável que o suplente permaneça filiado ao partido que o elegeu, "seja quando a vaga aberta pertence ao próprio partido ou à coligação por ele feita", para ter direito à vaga, que jamais poderia ser preenchida por membro de outro partido ou outra coligação. Com a mudança de partido haveria o cancelamento automático do vínculo, que configuraria uma "renúncia tácita a todas as prerrogativas dele decorrentes" e igualmente à suplência, devendo, tanto o suplente quanto o candidato eleito, "pertencer ao partido pelo menos até o momento da posse no cargo". A desfiliação importa a cessação da expectativa de direito à vaga, a ser preenchida pelo partido ou coligação. Esse foi o entendimento do Procurador-Geral da República, que opinou pela concessão da segurança $^{423}$.

Ricos para o presente estudo foram os votos proferidos no julgamento do MS 20.927, pois expõem argumentos em favor e contra a perda do direito do suplente que migrou de agremiação. Como será visto ao longo desse capítulo, deparar-se-á com os mesmos raciocínios nas decisões recentes sobre o tema, que ora serão usados para justificar a perda do mandato, ora para motivar a inexistência do princípio questionado.

Detendo-se, pelas razões supra expostas, na análise dos votos, inicia-se com a motivação apresentada pelo relator do MS 20.927, Ministro Moreira Alves, que

${ }^{421}$ Nesse sentido, dizia a Res. N. 15.135/89 do TSE: "Inexistente no nosso ordenamento jurídico a perda de mandato por infidelidade partidária, (...), muito menos perda de mandato, para o filiado que, detentor de cargo eletivo, deixa o Partido sob cuja legenda foi eleito a fim de transferir-se para outro." (grifos nossos). TSE, Res. N. 15.135, rel. Min. Roberto Rosas, 21.03.89, DJ 20.04.89.

${ }^{422}$ Lei N. 4.737 de 15 de julho de 1965, art. 112: Considerar-se-ão suplentes da representação partidária: I os mais votados sob a mesma legenda e não eleitos efetivos das listas dos respectivos partidos; II - em caso de empate na votação, na ordem decrescente da idade.

${ }^{423}$ STF, Pleno, MS 20.927-DF, rel. Min. Moreira Alves, 11.10.89, DJ 15.04.94. 
desde logo realçou a inexistência de qualquer sanção jurídica à troca de partidos no ordenamento vigente, posição tradicional e principal argumento daqueles que entendem não residir razão para a perda do mandato por infidelidade partidária. O Ministro pretendeu demonstrar que a omissão do constituinte foi proposital, uma vez que, a despeito deste ter alçado a representação político-partidária e o sistema proporcional a um elevado grau de importância no texto constitucional, optou por não punir a troca de legenda com a perda do mandato, ainda que onerando o sistema com a alteração da representação partidária no Parlamento. E o fez premeditadamente, pois, em querendo, "bastaria ter colocado essa hipótese entre as causas de perda de mandato, a que alude o artigo 55(CF/88)". O Ministro Moreira Alves ressaltou ser a Constituição omissa relativamente a qualquer previsão de consequências para os eleitos diplomados não empossados que trocam de legenda. Logo, do silêncio constitucional não se deve inferir a perda do direito à posse, conferido exclusivamente pela diplomação, sendo certo que a vinculação ao partido é tão somente condição de elegibilidade e não condição para a posse do eleito diplomado ${ }^{424}$. Por essa lógica, não decorre do princípio da representação proporcional, nem da valorização da figura do partido, qualquer sanção decorrente da infidelidade após a diplomação. O direito à substituição, próprio do suplente, decorre somente de sua diplomação como tal. Ademais, finalizou o Ministro Moreira Alves, "não se pode exigir do substituto a fidelidade que não se exige do substituído". Tendo sido ambos diplomados, não há de se falar em perda do direito à posse pela troca de grêmio partidário, diante da ausência de previsão constitucional, conforme opinou o relator.

Compartilhou das mesmas razões o Ministro Sepúlveda Pertence, cujas premissas se assemelharam à do relator, quais sejam, a ausência de base jurídica para decretar a perda do mandato e a não permissão do sistema constitucional para sancionar a infidelidade com a perda. Raciocínio este, extraído do rol exaustivo do artigo 55 CF/88, somado à inexistência da distinção entre a situação do titular e do suplente, nas palavras do douto Ministro Pertence. Ressaltou, ademais, que a coligação se forma para fins exclusivamente eleitorais, dissolvendo-se com o término do processo. Tanto assim, que em novo certame, novas coligações podem ser formadas. No mesmo sentido, observou que "a série de suplentes, até o fim do mandato, permanece em função da ordem decrescente de votação apurada na lista da coligação, e não segundo as diferentes legendas partidárias

${ }^{424}$ De acordo com o art. 53, § $1^{\circ}$., Constituição Federal da República do Brasil de 05.10.88, são considerados membros do Congresso Nacional os eleitos desde a expedição do diploma. 
coligadas.” Tal lógica se coaduna com a norma prescrita pela Resolução N. 13.605/87 anteriormente transcrita.

Por sua vez, o Ministro Célio Borja, que também indeferiu a segurança, trilhou raciocínio diverso, analisando a questão sob o prisma da competência e da separação de poderes. Uma vez diplomado o titular ou o suplente, somente outro ato da Justiça - e não do Parlamento - poderá destituí-lo. A competência recai sobre a Justiça especializada a quem cabe a prática de atos de reconhecimento das eleições e dos eleitos, ou, em termos semelhantes, o exame da legitimidade do mandato.

O Ministro Francisco Rezek, proferiu voto acompanhando a maioria, porém profetizou que ocorreriam mudanças em um futuro próximo, na essência da formação partidária, que trariam maior coesão, homogeneidade e redução no número de agremiações. Em suma, falou de uma maturidade dos partidos, como própria de uma evolução da democracia, na qual tais agremiações se reduziriam somente às facções que retratariam fielmente os diferentes pensamentos da sociedade e não proliferariam mais de forma a se tornarem incontáveis. Como visto, sem o artifício da cláusula de barreira, parece a profecia ter errado ao menos no prazo de sua concretização, à medida que, ainda hoje, vinte anos após o acórdão, um sem número de partidos busca o pleito eleitoral, com a maioria desvinculada de qualquer real identidade ideológica-social, as notórias "legendas de aluguel”. O Ministro Rezek vislumbrou uma regular evolução da democracia pelos partidos, tal como presente em países desenvolvidos, como o bipartidarismo norteamericano ou partidos com ideologias claras e firmes como os alemães. A despeito da proliferação dos partidos nacionais, não restam inválidos os respeitáveis argumentos tecidos pelo Ministro Rezek, que procurou trazer à fundamentação elementos históricoconstitucionais. Rememorou, assim, o momento da elaboração da Carta em 1988, quando a nação ainda se encontrava "naquela zona cinzenta" provocada pela tomada do poder pelos militares em 1964 e a decorrente dissolução dos partidos. De certo, a democracia pelos partidos era imberbe em nosso país: ressurgia das cinzas e deixava nebulosa ainda a situação futura dos partidos na retomada democrática. Sua previsão foi mais além, afirmando que o futuro renderia homenagem à tese em que se basearam os votos vencidos, que optaram por conceder a segurança. Não obstante, atendo-se ao direito positivado, tal como posto à época, denegou o Ministro a segurança, seguindo o voto do relator.

Outro voto que negou a exigência de fidelidade aos partidos foi o proferido pelo Ministro Aldir Passarinho. Entretanto, admitiu o próprio Ministro que, no início do julgamento do mandado de segurança, havia se manifestado em prol da perda do 
mandato eletivo do parlamentar e do suplente que saíssem da legenda pela qual se elegeram. Contudo, ateve-se também aos pressupostos estabelecidos de forma expressa no texto constitucional para justificar sua mudança de posicionamento, de modo a acompanhar o voto do relator. Adicionou entender a inexistência de omissão do constituinte sobre o tema, pois este esteve presente desde a EC-1/69, sendo posteriormente excluído de forma proposital.

Embora se observe a estrita atinência ao texto legal e a reiterada prevalência da interpretação constitucional gramatical sobre a principiologia, considerando-se os votos dos Ministros que denegaram a sanção ao infiel há quase duas décadas, o Ministro Passarinho deixou transparecer o gérmen da mudança, ao retratar que a situação ideal seria exatamente a oposta à que traçou em seu voto. Ou seja, a vinculação aos partidos políticos e o prestígio a estes, deveriam ser mais valorizados, uma vez que a Constituição vigente "está cheia de princípios nesse sentido", recordou o Ministro.

Em contraposição aos que indeferiram o pedido do impetrante, parte-se agora para averiguação dos argumentos encontrados nos votos vencidos dos Ministros Celso de Mello, Paulo Brossard, Carlos Madeira e Sydney Sanchez no MS 20.927/89. Porém, a razão maior que leva a deter-se na análise dos referidos votos não é a simples confrontação de ideias, mas a percepção de que seus argumentos já traziam, nas decisões precedentes, diferente e inovadora interpretação sobre a questão da fidelidade partidária, como poderá ser notado quando da comparação com as últimas decisões atinentes ao tema.

O primeiro voto dissidente em relação ao relator foi o produzido pelo Ministro Celso de $\mathrm{Mello}^{425}$, que enfatizou o monopólio dos partidos políticos, característico do Estado de Partidos, onde o regime democrático apresenta indispensável sustentação partidária, com o marcante traço da vinculação partidária, traduzida como condição de elegibilidade expressa no artigo 14 da Carta Magna. Citando J. AFONSO DA SILVA, o Ministro realçou o dever de fidelidade contido no art. 17, $\S 1^{\circ}$., CF/88, apontando, contudo, que tal obrigação não importa a possibilidade de perda do mandato por infidelidade, na trilha do pensamento do renomado jurista. Frisou, inclusive, a taxatividade das hipóteses de perda do mandato que a Constituição tutela, lembrando que a infidelidade não consta desse rol. Embora seus argumentos levassem a se vislumbrar, de início, uma posição semelhante à do relator, surpreendeu o Ministro Celso de Mello ao colocar que

\footnotetext{
${ }^{425}$ Celso de Mello capitaniaria a corrente majoritária que se formou em prol da fidelização ao partido, nos julgados do Supremo Tribunal Federal no ano de 2007. STF, Pleno, MS 26.603-DF, rel. Min. Celso de Mello, 04.10.07, DJE 19.12.08.
} 
"outra, porém, é a situação do suplente". Em sua lógica, o suplente, por não titularizar mandato legislativo, tem status jurídico diverso do parlamentar eleito, não the residindo direito subjetivo à vaga, mas mera expectativa. Justificou sua posição com fundo no sistema de representação proporcional e na apreensão do patrimônio das eleições - o voto - pelos partidos. Não se percebe em seu raciocínio, contudo, maior fundamentação no discrímen estabelecido entre a situação jurídica do titular e do suplente. O Ministro se limitou a colocar que o suplente não goza das mesmas prerrogativas e sujeições impostas aos titulares. Críticas a parte, fato é que o Ministro Celso de Mello considerou que a extinção do vínculo com o partido pelo qual o suplente obteve uma expectativa de direito ao mandato, quando de eventual vacância, resulta na perda da condição de suplente. Em suma, o dever de fidelidade se presta ao suplente, mas não ao titular, o que soa deveras contraditório.

Em oposição, a convicção do dever de fidelidade sancionável com a perda do mandato é marcante no voto do Ministro Paulo Brossard, retratando a corrente vencida no Supremo ao final dos anos 80. Após discorrer detalhadamente sobre a evolução do quadro histórico dos partidos políticos no Brasil, teceu sérias críticas ao excessivo números de partidos existentes à época. ${ }^{426}$ Sua argumentação partiu da relação intrínseca entre a representação proporcional e a fidelidade partidária. Trata-se de um dos principais argumentos de quem defende o instituto, que se apoia nas desvantagens da redução da representatividade do partido no parlamento: a diminuição do número de cadeiras decorrente do abandono do parlamentar e, de outra face, o enriquecimento sem causa do partido que abriga o parlamentar migrante. Naturalmente, essa teoria considera que o parlamentar não representa o povo, mas o partido, e este, sim, representa o povo. Sua investidura não o despe da insígnia da qual se utilizou para obtenção dos votos, segundo tal lógica. A troca de partido pelo suplente configura uma renúncia tácita da posição jurídica do parlamentar. Não fora assim, diz o Ministro, "ofendido estaria o princípio da representação proporcional e o resultado das urnas." O Ministro Brossard fez uso do que intitulou de uma interpretação sistêmica, contida em um acórdão unânime do Tribunal gaúcho publicado sob a égide da Constituição de 1946, no qual o Egrégio Tribunal estadual sustentou exatamente a manutenção da representação proporcional aos partidos, que por lei lhes é assegurada, e determinou a perda da condição de suplente de cargo

${ }^{426}$ Disse o Ministro Brossard: “(...) como se houvesse quarenta correntes de opinião definidas e com alguma consistência cívica.” STF, Pleno, MS 20.927-DF, rel. Min. Moreira Alves, 11.10.89, DJ 15.04.94. Note-se que, ainda hoje, vinte anos após o julgamento em tela, o quadro de multiplicidade dos partidos, a reduzida significação de suas legendas e fraqueza ideológica continuam sendo a tônica da realidade política nacional. 
eletivo quando rompido o vínculo partidário. Concluiu o Ministro, a partir daí, que o suplente que abandonou a agremiação pela qual concorreu ao pleito eleitoral renuncia tacitamente a sua condição, pois, de outra forma, lesaria o direito à vaga que pertence do partido. Como se percebe, não se travou um debate mais extenso sobre a questão mais recente: “a quem pertence a vaga: ao parlamentar ou ao partido?”. Implícita está no raciocínio do Ministro Brossard, a segunda opção, apesar do debate não ter se focado nesse ponto, ao contrário do que se observará nas decisões hodiernas.

Atendo-se ao texto do $\S 1^{\circ}$. do art. 17 da Constituição Federal, o Ministro Sydney Sanches, por sua vez, frisou a necessidade de os estatutos partidários conterem expressa previsão referente à fidelidade e à disciplina partidária. Sua omissão acarretaria a inviabilidade da representação de partidos. Deduziu que, não sendo permitido ao estatuto dispensá-las, seriam, portanto, inarredáveis do sistema jurídico. Entendeu ser possível ao Presidente da Câmara, independentemente de pronunciamento do Judiciário, não acatar o diploma do suplente em casos juridicamente supervenientes e relevantes, tal como a desvinculação do partido de origem. Reportou-se ao julgamento do Mandado 20.916, propagando sua indignação com a infidelidade não só ao partido, mas, além disso, ao eleitor. Assim, tal como o Ministro Sanchez, o Ministro Carlos Madeira, votou pela concessão da segurança, de modo a afastar o suplente infiel ${ }^{427}$.

Em conclusão ao julgamento do MS 20.927, o Tribunal, por maioria, indeferiu o pleito, preservando o entendimento na inaplicabilidade de qualquer sanção ao parlamentar ou suplente que abandonasse a sigla de eleição.

\subsubsection{MS 20.916/89}

Na mesma data (11/10/89) foi julgado o Mandado de Segurança 20.916, cujo objeto se assemelha ao MS 20.927, mas não é idêntico. Impetrado contra o Presidente da Mesa da Câmara dos Deputados, que convocara suplente que havia mudado de partido após as eleições, pretendiam o Partido Trabalhista Brasileiro (PTB) e o suplente seguinte da lista, então impetrantes, ter para si a vaga do suplente trânsfuga. O segundo suplente fora eleito pela Coligação União Liberal Trabalhista, formada pelo partido impetrante e o Partido Social Cristão (PSC), ao qual estava filiado o suplente litisconsorte passivo à época

${ }^{427}$ O Ministro Sydney Sanchez foi o pioneiro a falar em "fidelidade ao eleitor", retórica que, como será oportunamente apontado, foi amplamente empregada nas decisões recentes das Cortes. STF, Pleno, MS 20.927-DF, rel. Min. Moreira Alves, 11.10.89, DJ 15.04.94. 
da eleição de 1986, e que, posteriormente a essa, migrou para o Partido do Movimento Democrático Brasileiro (PMDB) para concorrer às eleições municipais de 1988. Alegaram os impetrantes a perda da condição jurídica de suplente que lhe daria a expectativa de assumir a vaga, arguindo que essa pertencia à representação pela qual o suplente disputou o pleito, bem como fundamentando na distribuição proporcional prevista nos artigos 108 e 109 do Código Eleitoral.

Em suma, apesar do extenso debate travado entre os Ministros no julgamento do MS 20.916, presenciam-se os mesmos elementos analisados referentes ao julgamento do Mandado 20.927, apenas com diferentes partes litigantes. Outro elemento diferenciador se assevera, sem, porém, alterar substancialmente o resultado do julgamento: o suplente que havia se filiado ao PMDB, não logrando sucesso nas eleições municipais de 1988, retornara ao partido de origem (PSC) um dia antes de ser empossado na vaga aberta a Deputado Federal. Face ao ocorrido, considerou o Ministro relator Carlos Madeira, que, ao desligar-se do partido originário, o suplente perdera essa condição, a qual não se restabeleceria pelo retorno ao partido de origem, ainda que tempestivo. Ao contrário, o abandono consumado criou o direito à vaga ao suplente seguinte na ordem estabelecida nas eleições (no caso em tela, ao terceiro suplente, o impetrante). Sua decisão coadunou-se com parecer do Ministério Público, segundo o qual "a filiação a outro partido (...), acarreta o cancelamento automático e definitivo do vínculo com este partido e constitui renúncia tácita (...) a todas as prerrogativas dele decorrentes (...) e também à condição de suplente." Acrescentou o Ministro não se tratar de discussão a respeito da fidelidade partidária, mas antes da diferenciada condição de suplente vis a vis a condição do detentor de mandato parlamentar. Diferenciação essa não aceita pelo Ministro Sepúlveda Pertence que, inaugurando a dissidência, considerou similares o status do suplente e do mandatário titular, devendo igualdade ao tratamento de ambas as situações perante a questão da fidelidade partidária. O Ministro Pertence denegou a segurança, fundamentando seu voto na inexistência de norma que preveja ser do partido o mandato, assim como de norma sancionatória à transmigração. Durante o debate, acrescentou ainda que discordava daqueles que entendem ser o mandato um direito do partido para manter a representação (posição que viria a cambiar dezoito anos após). Para tanto, arrazoou sua lógica na efemeridade do instituto da coligação, que se desfaz tão logo findas as eleições. Repetindo seu argumento aposto no julgamento contemporâneo, o Ministro afirmou que, respeitada a ordem para convocação dos suplentes, deixa a coligação de existir, dando lugar às bancadas parlamentares independentes, que não guardam qualquer relação com a coligação 
extinta. No momento da reposição da vaga pelo suplente, o partido " $A$ " pelo qual o titular se elegeu, não tem relação alguma com eventual suplente do partido "B”, ainda que ambos fossem da extinta coligação vencedora. Esse foi o ponto do contra-argumento do Ministro Sepúlveda Pertence, que não pode ser descartado.

Para o Ministro Brossard o foco da decisão se concentrava na existência de direito individual, líquido e certo do impetrante em assumir a deputação, tendo em vista fato superveniente à diplomação, que o levaria - ou não - à condição de primeiro suplente. Desviou o debate da questão da fidelidade partidária, argumentando ser fato atinente à natureza do partido político e do mandato parlamentar. Seu raciocínio funda-se na medida da representatividade do partido no Parlamento, que lhe concede uma série de direitos. $\mathrm{O}$ próprio mandato é, para o Ministro, um direito do partido. A redução da representatividade, pela perda da vaga, é uma lesão ao direito do partido. Em sintonia com os Ministros Celso de Mello e Sydney Sanchez, a lógica do Ministro Brossard decorre do acórdão proferido no RE 99.884-5 de 1983, no qual se identificou lesão ao direito do partido, decorrente mudança partidária do primeiro suplente. Afirmou que tal acórdão não se baseou na fidelidade partidária, mas antes na natureza da representação política ${ }^{428}$. Lembrou que o sistema constitucional abarca princípios que permitem uma interpretação nesse sentido, embora não expressamente se preveja a hipótese.

Em linha de argumentação similar, o Ministro Sydney Sanchez tratou do assunto como lesão ao direito do partido. Reportando-se ao parecer da Procuradoria, ressaltou a diferença da situação jurídica do titular perante à do suplente:

“(...) a infidelidade partidária não acarreta a perda do mandato do Deputado Federal, pois evidentemente ocorre após a posse no mandato. Já a fidelidade partidária é condição necessária à obtenção do mandato, pois a eleição decorre da coexistência dos dois direitos, do partido e do candidato, apurados antes da posse no mandato" 429. (grifos no original)

Note-se que, de acordo com o parecer, considera-se diferenciada a situação jurídica do suplente em face da do Deputado. Nesse sentido, o Ministro acrescentou que se o suplente ficasse sem qualquer filiação a algum partido, não poderia

${ }^{428}$ Este argumento foi rebatido pelo Ministro Aldir Passarinho, que lembrou ter sido a aludida decisão proferida em época que a fidelidade partidária era norma expressa do ordenamento, e que somente viria a ser retirada dois anos depois, com a EC 25/85. A fidelidade partidária, ainda que como princípio a ser observado, não deixara de ser causa determinante da perda do mandato e assim permanece no sistema vigente. No entender do Ministro Passarinho, a atual Constituição consagra o princípio da fidelidade partidária, mas não na mesma extensão que sua antecedente, ou seja, não pune com a perda do mandato. STF, Pleno, MS 20.916DF, rel. Min. Sepúlveda Pertence, 11.10.89, DJ 26.03.93.

${ }^{429}$ STF, Pleno, MS 20.916-DF, rel. Min. Sepúlveda Pertence, 11.10.89, DJ 26.03.93. 
assumir a vaga. Inferiu, a partir dessa lógica, que o trânsfuga também não teria o direito à suplência. Ele foi advertido pelo Ministro Rezek de que o sistema pátrio veda a candidatura avulsa e não o mandato por quem não esteja filiado. Os demais Ministros proferiram seus votos de maneira semelhante e por vezes idêntica àqueles apresentados no julgamento do MS 20.927 (como se nota no voto dos Ministros Celso de Mello, Moreira Alves e Néri da Silveira).

A riqueza da análise da jurisprudência formada nos anos próximos ao nascimento da Constituição Federal de 1988 é claramente percebida nos diferentes e antagônicos argumentos empregados para se justificar a possibilidade ou a proibição de se penalizar com a perda do direito à vaga o suplente que se desfiliou do partido pelo qual foi eleito. Essa importância se revelará de modo efusivo na aproximação desses fundamentos aos recentemente empregados pelas Cortes ao se decidir novamente a questão da fidelidade partidária, em sentido diverso da jurisprudência então formada. Nesse espectro, chama atenção o apontamento do Ministro Sydney Sanchez que se indignou, já à época, relatando ter achado "curioso que todo o Tribunal repugna a fidelidade", mas nada se faz para obstar a prática $^{430}$. O embrião da jurisprudência em favor da fidelidade partidária, que viria a ser consolidada em 2007, já se fazia presente na corrente minoritária do STF desde 1989.

\subsection{O marco da mudança no TSE}

A transmigração partidária, fenômeno conhecido desde a consolidação dos partidos políticos, atingiu, na presente década, níveis socialmente inaceitáveis ${ }^{431}$. O sentimento de repulsa a movimentos anti-éticos se exacerba de tempos em tempos, mas fato é que a sociedade vê o Congresso Nacional cada vez mais distante de sua função representativa popular. Ao contrário, a percepção cotidiana traz a sensação da perpetuação de oligarquias em disputa do poder, visando interesses de poucos, quando não os próprios.

Entende-se como o marco da mudança do posicionamento de nossas Cortes relativamente à questão da fidelidade partidária, a resposta vinculante do TSE à Consulta N. 1.398 e a consequente edição da Resolução N. 22.526, em 27 de março de

\footnotetext{
${ }^{430}$ STF, Pleno, MS 20.916-DF, rel. Min. Sepúlveda Pertence, 11.10.89, DJ 26.03.93.

431 Entre 1985 e 2002, em cinco legislaturas, ocorreram 1.041 mudanças de partido, envolvendo 852 Deputados. Para estatísticas da migração partidária no período, cf. C. RANULFO MELO, Retirando as cadeiras do lugar, Belo Horizonte, UFMG, 2004, p. 66 e 161.
} 
$2007^{432}$. No início daquele ano, o Tribunal Superior Eleitoral, diante da inoperância do Legislativo em produzir normatização a respeito do tema da migração partidária, foi obrigado a se manifestar em resposta ao procedimento de Consulta formulado pelo DEM (à época PFL - Partido da Frente Liberal), que pretendia que os partidos e coligações tivessem recuperadas as vagas ocupadas por parlamentares que trocaram de legenda ou que houvessem cancelado sua filiação, considerando-se o teor do art. 108 do Código Eleitoral (Lei 4737/65), que estabelece toda a engenharia eleitoral partidária dentro de um sistema eleitoral proporcional. A Consulta também se fundamentou na condição de elegibilidade, qual seja, a da filiação a um partido.

O motivo da provocação à Corte Eleitoral máxima se revela no contexto político social supra descrito e nas estatísticas apontadas no voto do relator da Consulta mencionada, Ministro Asfor Rocha. Citou o ilustre Ministro um levantamento efetuado pelo Tribunal Superior Eleitoral, segundo o qual, em um curto período - do início da legislatura de 2006 até a data da propositura da questão - trinta e seis parlamentares saíram do seu partido de origem nas eleições referidas, sendo que a grande maioria (vinte e oito parlamentares) cambiou seu posicionamento ideológico ao passar para partidos opositores. O que se observou, nas últimas quatro legislaturas do Congresso Nacional, foi a troca de postos da oposição para a chamada "base governista". Fato este, decorrente das vantagens de estar ao lado do governo. Por duas vezes, desde 1994, presenciava-se a recondução do Presidente da República para um mandato subsequente. Essa proximidade do parlamentar da base governista gera, sem dúvida, benefícios, vantagens e propicia maior poder. O país assistia perplexo, porém apaticamente, a troca de favores no meio político, que se propagava no mesmo ritmo da troca de partidos. A título de exemplo, presencia-se a nomeação de Ministros e cargos de primeiro escalão nas estatais e autarquias, de líderes ou membros dos partidos da base governista. Não seria tampouco o próprio Congresso a buscar alteração nessa 'flexibilidade' presente na permissividade de troca de agremiação a

${ }^{432}$ TSE, Consulta N. 1.398/DF e Resolução N. 22.526, rel. Min. Celso Asfor Rocha, 27.03.07, DJ 08.05.07. A Consulta, formulada pelo PFL, com base no art. 23, XII, da Lei 4737/65, foi efetuada nos seguintes termos: "Considerando o teor do art. 108 da Lei N. 4.737/65 (Código Eleitoral), que estabelece que a eleição dos candidatos a cargos proporcionais é resultado do quociente eleitoral apurado entre os diversos partidos e coligações envolvidos no certame democrático. Considerando que é condição constitucional de elegibilidade a filiação partidária, posta para indicar ao eleitor o vínculo político e ideológico dos candidatos. Considerando ainda que, também o cálculo das médias, é decorrente do resultado dos votos válidos atribuídos aos partidos e coligações. INDAGA-SE: Os partidos e coligações têm o direito de preservar a vaga obtida pelo sistema eleitoral proporcional, quando houver pedido de cancelamento de filiação ou de transferência do candidato eleito por um partido para outra legenda?" 
qualquer tempo e por qualquer razão. Não pareceu ser interesse da classe parlamentar findar os privilégios e benesses advindas da migração.

\subsubsection{Consulta N. 1.398-TSE - O voto do relator e os principais argumentos pró-fidelidade}

O relator, Ministro Celso Asfor Rocha ${ }^{433}$, pontuou desde logo não ser novo o questionamento sobre a quem pertence o mandato eletivo: ao candidato eleito ou ao grêmio político. Narrou brevemente a história da evolução dos partidos, considerando-os imprescindíveis e "autênticos protagonistas da democracia representativa", notando a condição de elegibilidade trazida pelo art. $14, \S 3^{\circ}$., $\mathrm{V}, \mathrm{CF} / 88$, que exige do candidato a filiação partidária, cuja inexistência obsta a participação no pleito eleitoral. Tal norma se complementa com o dispositivo que assegura aos partidos a criação das normas internas de fidelidade e disciplina ${ }^{434}$. O Ministro caracterizou o Estado de Partidos, descrevendo-o como uma "partidocracia", termo com significado similar ao empregado por SÉRGIO RESENDE DE BARROS, "politicatura" - a ditadura da classe política - na obra em que relata o papel secundário da participação popular direta face à posição a que foram alçados os partidos nas democracias hodiernas ${ }^{435}$. A necessidade para operacionalização da democracia representativa proporcionou às entidades partidárias exponencial deferência no ordenamento jurídico.

\subsubsection{A força normativa dos princípios}

O cerne do debate travado na resposta à Consulta N. 1.398 do TSE teve seu foco direcionado também a questões extrínsecas à fidelidade partidária. De pronto, o Ministro relator considerou que o deslinde da questão deve ter a "indispensável correlação da própria hermenêutica constitucional, com a utilização prestimosa dos princípios que a

\footnotetext{
${ }^{433}$ TSE, Consulta N. 1.398/DF, rel. Min. Celso Asfor Rocha, 27.03.07, DJ 08.05.07.

${ }^{434}$ Art. $17, \S 1^{\circ}$, Constituição Federal da República do Brasil de 05.10.88.

${ }^{435}$ S. RESENDE DE BARRos, Contribuição dialética para o constitucionalismo, Campinas, Millennium, 2008, p. 65 .
} 
Carta Magna alberga", tendo em vista a "superação da velha hermenêutica"436. Tal posicionamento, como pode ser observado no segundo capítulo, reflete a corrente póspositivista, que propõe o alargamento das fronteiras da hermenêutica.

O Ministro Celso Asfor Rocha reconheceu a existência da jurisprudência formada em torno da impossibilidade de perda do mandato por infidelidade, bem como das posições doutrinárias que imputam ao parlamentar o mandato eletivo, ainda que se desfilie do partido pelo qual logrou sucesso nas eleições. Porém, taxou essa orientação de "pretoriana" e ultrapassada, distanciada do "espírito de nosso tempo", que almeja a probidade e moralidade pública e promove o acatamento à força normativa dos princípios constitucionais.

Ao evocar-se a aplicabilidade imediata dos princípios, com ênfase ao princípio da moralidade, inserido no art. 37 da Constituição, que repudia o uso de prerrogativa pública no interesse particular, afastou-se, de imediato, todo e qualquer limite imposto pelo ordenamento, dado por textos normativos constitucionais e legais, proclamando-se solenemente, que não possui "relevo algum afirmar que não se detecta a existência de norma proibitiva de tal prática"437. Tudo indica que foi descartado, deste modo, qualquer limite para a aplicação do princípio da moralidade, indo além da proposta extensão das fronteiras interpretativas, ou seja, não se deparando com qualquer barreira que mantenha íntegro o sistema ao conjugar princípios com previsões expressas do ordenamento. Não na visão do Ministro relator, para quem a Consulta em tela trouxe a oportunidade de revisão da chamada "teoria estruturalista do Direito", na qual o fenômeno jurídico se funda tão somente na sua dimensão formal positiva, deixando em plano inferior os valores relativamente às normas que conteriam por si sós um objetivo pronto, ou seja, seriam auto-suficientes. Tal teoria foi substituída, diz o Ministro apoiando-se em NORBERTO BoBBIO, pela escola funcionalista, que traz à luz a interpretação teleológica, que considera a finalidade as normas, postura enriquecedora do direito. Enfatizou ser função legítima das Cortes de Justiça, na colmatação do pensamento jurídico, "contribuir para o conhecimento dos aspectos axiológicos do Direito, abandonando-se a visão positivista tradicional, certamente equivocada, de só considerar dotadas de força normativa as regulações normatizadas; (...)”. Esse típico posicionamento reflete a corrente pós-

\footnotetext{
436 De acordo com o Ministro Celso Rocha, as normas são compostas de regras e princípios, aos quais recorre o intérprete da Constituição na busca de soluções jurídicas. TSE, Consulta N. 1.398/DF, rel. Min. Celso Asfor Rocha, 27.03.07, DJ 08.05.07.

${ }^{437}$ Cf. voto do Min. Celso Asfor Rocha, TSE, Consulta N. 1.398/DF, rel. Min. Celso Asfor Rocha, 27.03.07, DJ 08.05.07.
} 
positivista, que, conforme estudado no capítulo anterior, propõe uma intensa aplicação dos princípios pelo intérprete da Constituição. Os riscos deste entendimento, que nega a existência de limites à interpretação jurídica, foram precisamente apontados por ELIVAL DA SILVA RAMOS:

\begin{abstract}
"Nesse sentido, a exacerbação da importância dos princípios constitucionais, marca indelével da teorização moralista, não tem outra finalidade senão dotar o intérpreteaplicador de liberdade para, se necessário, corrigir (ou, em hipóteses extremas, até mesmo recusar validade) o direito posto, em nome de uma pretensa ordem objetiva de valores imposta pela razão (Alexy) ou pela vivência histórica de uma comunidade (Dworkin).", 438
\end{abstract}

A posição em prol da aplicação dos princípios como fonte normativa, vencedora do julgamento da fidelidade partidária, defrontou-se com a visão do Ministro Marcelo Ribeiro, que afirmou que os princípios são aplicados desde sempre, inclusive em decisões precedentes sobre a mesma temática e não seria subitamente que se deixaria de reconhecer tanto o conjunto de princípios constitucionais, quanto os limites impostos pelo texto positivado.

\title{
3.4.1.2 Possíveis razões para a migração partidária e a "traição ideológica”
}

A conduta da troca de partidos soa mesmo antiética, condenável. Responsável por instabilidade institucional. De acordo com o diagnóstico realizado pelo Ministro Peluso, muito da debilidade do quadro político-partidário pátrio advém da "indiferença oficial e popular quanto à desenfreada transmigração partidária"439. Causa certo incômodo a ideia de que um parlamentar associado a uma corrente ideológica e a um suposto programa de governo - que também em teoria o identificou como candidato pertencente a esta corrente - mude, sem justificativas, para qualquer outra agremiação. Ao menos quando a troca ocorre para agremiações cujas ideias sejam diametralmente opostas.

\footnotetext{
${ }^{438}$ E. S. RAMOS, Parâmetros dogmáticos do ativismo judicial em matéria constitucional, Tese de Titularidade apresentada à Faculdade de Direito da Universidade de São Paulo, 2009, p. 263.

${ }^{439}$ O Ministro Peluso vai mais além: a infidelidade ao programa partidário é nociva à preservação do Estado de Partidos, traz a descrença eleitoral e risco ao regime democrático de se transformar em autoritário ou totalitário. Cf. voto Min. Peluso, TSE, Consulta N. 1.398/DF, rel. Min. Celso Asfor Rocha, 27.03.07, DJ 08.05.07.
} 
Mas nem sempre essa hipótese se verifica no caso concreto, o que leva, então, a se refletir sobre o argumento de que há uma traição ideológica. Primeiramente, haveria de se averiguar se esta ideologia existe e é consistente, o que somente poderia ser constatado caso a caso. O fato de um parlamentar mudar de partido dentro de uma coligação, ou dentro da base governista ou, ainda, entre partidos de oposição ao governo considerando-se ademais o fraco e inexpressivo conteúdo ideológico da maioria das agremiações - configura uma situação que não permite de pronto se afirmar com tamanha contundência a ocorrência de 'traição' a qualquer ideologia. Nos termos do Ministro Peluso, deve se perquirir sobre os reais motivos da troca partidária, "em busca da identificação de quem lhe deu causa e das respectivas consequências".

Porém, no calor do debate e com certa falta de zelo, proferiu o Ministro Marco Aurélio: "não sou investigador político, mas sabe lá como essas trocas se fizeram, quais foram as motivações" ${ }^{440}$. A simples imaginação e o conhecimento do deteriorado quadro político nacional pode levantar as mais sórdidas hipóteses de favorecimento, vantagens pecuniárias, oportunidades eleitoreiras, acesso a cargos de governo e de comissões parlamentares, além de outras motivações para as trocas de legenda. Todavia, não se pode penalizar a todos pela simples generalização, pelo desconhecimento dos fatos ou sentimento de reprovação. Daí a importância dos princípios da ampla defesa e do contraditório, que possibilita a análise de cada caso adentrando-se na real razão que levou o parlamentar a buscar outra legenda. A maioria dos Ministros julgadores da Consulta reconheceu exceções que configuram justa causa para a troca de agremiação ${ }^{441}$.

Outro problema, que inclusive promove a personalização, são as disputas dentro do próprio partido, quando da indicação de seus candidatos. O sistema de listas abertas promove o individualismo nas campanhas eleitorais. Fator igualmente crucial no estudo do fenômeno é a relação entre a ideologia partidária e a troca de partido.

Nesse sentido, duas linhas de argumentação diametralmente opostas se constroem em torno da existência e relevância de uma suposta traição ideológica. A primeira admite ser verdade que a ocupação da cadeira parlamentar é determinada,

\footnotetext{
${ }^{440}$ Cf. voto Min. Marco Aurério, in TSE, Consulta N. 1.398/DF, rel. Min. Celso Asfor Rocha, 27.03.07, DJ 08.05.07.

${ }^{441} \mathrm{O}$ Ministro Peluso cita como exceções à perda do mandato a significativa alteração de programa do partido e a perseguição política ao parlamentar que abandona o partido por esse motivo. Surgem algumas questões, ao se empregar a lógica demonstrada pelo Ministro Peluso: se o eleitor entregou seu voto a um programa partidário - conforme propõem a maioria dos Ministros - que foi alterado no decorrer da legislatura (e.g., o partido pertenceu a coligação não vencedora nas eleições e passa a apoiar o governo eleito), teriam sido seus eleitores igualmente traídos, à luz da 'teoria da traição'? Esse partido perderia, então, todas as suas cadeiras? TSE, Consulta N. 1.398/DF, rel. Min. Celso Asfor Rocha, 27.03.07, DJ 08.05.07.
} 
primeiramente, pelo número de votos recebido pelo partido. Porém, considera que o sucesso do candidato depende de sua capacidade de obter votos para si. "Os representantes eleitos consideram seus mandatos como decorrentes de seus esforços pessoais, mais do que de uma boa campanha do partido". ${ }^{442}$ Por esse raciocínio, configurar-se-ia um capital privado do candidato e, ao contrário do que se supõe como regra, "as trocas têm ocorrido, em geral, dentro do mesmo espectro ideológico, e se verificam mais nos partidos menos coesos, mais novos, com menor tradição na política" ${ }^{443}$. Essa importante constatação acabaria por solapar toda "teoria da traição", argumento presente nos votos favoráveis à fidelidade partidária proferidos pelos Ministros do TSE, que consideraram a migração uma “traição ao eleitor". Ressalta-se, todavia, que as estatísticas que fundamentam a percepção de que as trocas ocorrem dentro de uma mesma ideologia não são de todo recentes, senão vejamos o que se encontra no informativo elaborado pelo Senado Federal:

\begin{abstract}
"Na década de 90, 48,3\% dos Deputados eleitos pelo conjunto dos partidos de direita menos o PFL mudaram de partido, optando, a esmagadora maioria, por migrar para uma legenda situada dentro do mesmo campo ideológico. Isto significa que, no que se refere à direita, as fronteiras entre os partidos possuem muito pouco significado. Estar no PTB, no PPB ou numa sigla de menor expressão é algo que, para boa parte dos congressistas, explica-se pela combinação um tanto fortuita de fatores vinculados á sua viabilidade eleitoral. Sua opção partidária pode mudar a qualquer hora. Em menor grau isto vale para o centro: basta ver a intensidade das trocas entre PMDB e PSDB."
\end{abstract}

De acordo com CARLOS RANUlfo Melo, estudando o período de 1985 a 2002, observa-se um reduzido número de deputados que cruza o espectro, o que corrobora a hipótese de que as mudanças ocorrem dentro da mesma ideologia. Porém, adverte o autor, que a "direita" migra com mais intensidade, mas com maior coerência ideológica, enquanto a "esquerda", por sua vez, migra menos vezes, mas de forma mais incoerente com suas ideias $^{444}$.

Valendo-se desses dados, pouco haveria de se argumentar em prol de uma "traição ideológica", ainda que se considerasse que todos partidos brasileiros contenham fortes concepções ideológicas, o que de fato não se presenciava no período póspromulgação da Carta Constitucional, bem como não se percebe nos dias de hoje. Porém, tal entendimento se opõe aos argumentos reiterados nas decisões, de acordo com os quais, no sistema proporcional, o parlamentar se utiliza da estrutura dos votos do partido para se eleger.

442 E. CRUXÊN MACIEL, Fidelidade partidária - um panorama institucional, disponível (on line) in http://www.senado.gov.br/web/cegraf/ril/Pdf/pdf_161/R161-08.pdf., [24.11.07].

${ }^{443}$ E. CRUXÊN MACIEL, Fidelidade partidária - um panorama institucional, cit.

${ }^{444}$ C. RANUlFo Melo, Retirando as cadeiras do lugar, cit., p. 102-3. 
O retrato das recentes e intensas migrações mostra que estas têm ocorrido no sentido de incrementar a base governista, revelando que o parlamentar parte em busca de melhor alternativa partidária, que é, por exemplo, a que lhe promove acesso aos recursos disponibilizados pelo Poder Executivo, recursos esses que serão alocados em suas bases eleitorais, para garantir a reeleição. Em análise do panorama político institucional, ELAINE CRUXÊN MACIEL desenha um claro quadro da situação:

\begin{abstract}
"O controle sobre recursos de ordem política por parte dos partidos, ou de cada Deputado, possibilita grande vantagem competitiva no contexto eleitoral brasileiro. Aos partidos, através de seus líderes, interessa o acesso às arenas decisórias e o controle de 'territórios', no interior do governo, capazes de funcionar como fonte de recursos utilizáveis na intermediação das relações com seus pares e com a sociedade. Ao Deputado individualmente interessa situar-se em posição que possibilite um bom desempenho na execução de uma estratégia voltada para a transferência de recursos públicos para o benefício exclusivo de sua base eleitoral." 445
\end{abstract}

Carlos Ranulfo Melo, em sua completa obra sobre o tema ${ }^{446}$, comprova com base em dados estatísticos as razões possíveis para o excesso de migração partidária. O início do processo se deu com a "desestabilização da matriz bipartidária do sistema inagurado em 1979" que criou condições para que houvesse alternativas partidárias disponíveis aliadas a um baixo custo de mudança, a um baixo índice de identificação partidária e à possibilidade de aumento de chances de sucesso na carreira de Deputado, principalmente pelo fácil acesso aos valiosos recursos para a disputa eleitoral. Em suma, "a legislação eleitoral revelou-se permissiva" e contribuiu para a corriqueira troca partidária. $\mathrm{O}$ autor adiciona ainda outro componente no atual quadro institucional da política brasileira: "a concentração de poderes legislativos institucionais e regimentais nas mãos do Presidente da República e dos líderes partidários”, o que levou à busca de uma melhor posição ao Deputado visando se aproximar desse poder ${ }^{447}$. O troca-troca tornou-se endêmico, segundo o autor, devido a essa estratégia adotada para reduzir "o nível de incerteza do parlamentar a respeito de seu futuro político", fornecendo às migrações um padrão associado à sobrevivência e ao sucesso político, mormente por possibilitarem essas trocas, "maior acesso aos recursos disponibilizados pelo aparato governamental". A

\footnotetext{
${ }^{445}$ E. CRUXÊN MACIEL, Fidelidade partidária - um panorama institucional, cit.

${ }^{446}$ C. RANULFO MELO, Retirando as cadeiras do lugar, cit., p. 161-171.

447 Segundo C. RANUlfo Melo, "ao longo do período governamental de Fernando Henrique Cardoso, a cooptação de deputados acabou por se transformar em mais um instrumento utilizado pelos líderes nas disputas internas à coalizão governista”. Retirando as cadeiras do lugar, cit., p. 161-171. Note-se que o mesmo fato se observa nos dois governos do Presidente Lula.
} 
filiação a uma sigla é objeto de negociação parlamentar, que gera instabilidade no sistema político partidário.

De outro lado, comparando-se as taxas de reeleição dos Deputados nãomigrantes em relação aos migrantes, apresentadas por CARLOS RANULFO MELO, percebe-se que não houve "uma atitude punitiva por parte do eleitor relativamente aos segundos". Isso decorre das características da cultura política brasileira, que tem no desinteresse e na apatia do eleitorado sua principal característica. Como prediz CARLos RANULFo MELO,

\footnotetext{
"se, em democracias menos peculiares do que a nossa, é possível ao cidadão atento julgar o desempenho de um Deputado observando a postura de seu partido, no Brasil essa possibilidade é dificultada pelas frequentes trocas de legenda." 448
}

Em resumo, todos os entendimentos apresentados são concordes em que a constante troca de quadros não é salutar ao Estado Democrático de Direito brasileiro. Nisso, são uníssonos os pensamentos aqui contrapostos, tanto da doutrina quanto dos Tribunais. Não obstante, para a corrente majoritária no TSE, essa alteração na composição da representação partidária no parlamento assume fatal importância: causa uma desconexão entre o sistema partidário eleitoral e o sistema partidário parlamentar, à medida que o desenho formado pelo resultado das eleições acaba por ser alterado durante a legislatura, implicando uma traição ao eleitor ${ }^{449}$. Opostamente, a corrente minoritária no TSE e a doutrina citada, enxergam tais consequências sob outro ângulo: o que atinge o eleitor, que não votou em sua maioria pela concepção ideológica partidária, não é a traição ideológica do parlamentar. Afeta-se o sistema eleitoral, mas por dificultar o acompanhamento do seu candidato. Assim, "se, em democracias menos peculiares do que a nossa, é possível ao cidadão atento julgar o desempenho de um Deputado observando a postura de seu partido, no Brasil esta possibilidade é dificultada pelas frequentes trocas de legenda". 450

Em conclusão, diante da fraqueza ideológica da maioria dos partidos existentes na recente história democrática nacional, torna-se difícil caracterizar-se a uma traição, quando não se exige e não se espera do parlamentar nem do partido uma firmeza ideológica. A personalização da política apaga os vestígios de uma traição à medida que coloca o conteúdo ideológico em segundo plano. Vide as eleições municipais paulistanas

\footnotetext{
${ }^{448}$ C. RANUlFo Melo, Retirando as cadeiras do lugar, cit., p. 170-171.

${ }^{449}$ Cf. voto dos Ministros Cezar Peluso e Celso Asfor Rocha. TSE, Consulta N. 1.398/DF, rel. Min. Celso Asfor Rocha, 27.03.07, DJ 08.05.07.

${ }^{450}$ E. CRUXÊN MACIEL, Fidelidade partidária - um panorama institucional, cit.
} 
de 2008, nas quais o candidato vencedor do DEM obteve apoio do Governador do estado eleito e filiado ao PSDB, em detrimento do candidato de seu próprio partido.

\subsubsection{A quem pertence o mandato?}

Partindo da premissa de que o vínculo de um candidato ao partido "é o mais forte, se não o único, elemento de sua identidade política", considerou o Ministro relator Celso Rocha que o candidato "não existe fora do Partido Político". Dessa condição de elegibilidade, extraiu a consequência pela qual seria "equivocada e mesmo injurídica a suposição de que o mandato político eletivo pertence ao indivíduo eleito", pois este não poderia se tornar detentor de parcela da soberania popular.

Com a devida vênia à lógica traçada pelo Ministro, à primeira vista, parece a conclusão não derivar da assertiva inicial. Não há como se vislumbrar relação de causa e efeito entre a premência de se filiar a uma agremiação para participar do pleito eleitoral e a 'propriedade' do mandato político. Ademais, como se verá no decorrer deste capítulo, soa incorreto buscar a solução à infidelidade na questão 'a quem pertence o mandato', independentemente da resposta, pois esta não é a pergunta a se fazer quando se trata de representação política. Ora, se não reside razão na 'usurpação' de parcela da soberania popular pela pessoa do parlamentar, tampouco se justificaria transformar o mandato em propriedade de um partido, simplesmente porque a soberania do povo não é apropriável. Fato é que a corrente majoritária se fundamentou na assertiva de que o mandato pertence ao partido e não ao eleito. O próprio Ministro Celso Asfor esmiuçou a questão, afirmando que o mandato eletivo "se configura essencialmente como uma função política e pública, de todo avessa e inconciliável com pretensão de cunho privado" e que "não pode integrar o patrimônio privado de um indivíduo" 451 . Fica o questionamento: poderia, então, o mandato integrar o patrimônio de um grupo de indivíduos ou uma associação de direito privado? Se público, qual relação jurídica lhe permite pertencer a uma organização de direito privado? Mais além: é correto falar-se em apropriação do mandato ou essa seria a verdadeira contrafação à natureza do mandato?

Clemerson Merlin Clève, que é citado pelo Ministro Peluso no julgamento em referência, parece ter, na verdade, opinião divergente do ilustre Ministro. Para o autor, o mandato decorre dos poderes conferidos pela Constituição, e o partido não

${ }^{451}$ TSE, Consulta N. 1.398/DF, rel. Min. Celso Asfor Rocha, 27.03.07, DJ 08.05.07. 
pode dispor livremente sobre o mandato. C. M. CLÈVE acrescenta: "Ainda que, doutrinariamente, o regime do mandato possa sofrer crítica, é induvidoso que, à luz do sistema constitucional em vigor, o mandato não está à disposição do partido." ${ }^{452}$. O referido autor ressalta que o mandato no Brasil é representativo e não imperativo. Isso implica que a fidelidade partidária "deve ser utilizada de forma moderada, jamais agredindo os direitos fundamentais do parlamentar, em especial a liberdade de consciência”, proibindo-se seu uso quando da ofensa da natureza da representação. Assim, conclui o autor que "o território da fidelidade partidária não é ilimitado, sendo certo que suas fronteiras derivam também da incidência de outros dispositivos da Constituição Federal $^{453}$." Em igual entendimento, M. HeRman SALEM CAGgiano mostra que a casa legislativa é composta de representantes do povo - nos termos do art. $45 \mathrm{CF} / 88^{454}-\mathrm{e}$ somente pelo povo poderá ser julgado quanto à sua conduta. Estamos falando da responsiviness, instituto estudado na primeira parte desse trabalho. É ao povo que se prestam contas. E são os parlamentares que prestam contas, não os partidos. Há, conforme proclama a autora, uma rede protetora de nível constitucional ${ }^{455}$ protegendo a figura do candidato, garantindo-lhe as liberdades próprias do regime democrático. O raciocínio indutivo, que parte da relevância inequívoca do sistema proporcional e da força dos partidos no Estado de Partidos, para afirmar que o voto pertence ao partido, desconsidera a origem e a finalidade da representação. De certo cada partido tem sua representatividade no parlamento, que decorre do resultado das eleições. Contudo, com todo respeito que lhe

${ }^{452}$ C. M. Clève, Fidelidade Partidária, Curitiba, Juruá, 1998, p. 26.

${ }^{453}$ C. M. CLÈVE, Fidelidade Partidária, cit., p. 31.

${ }^{454}$ Art. 45, Constituição Federal da República do Brasil de 05.10.88. - "A Câmara dos Deputados compõe-se de representantes do povo, eleitos, pelo sistema proporcional, em cada Estado, em cada Território e no Distrito Federal". (grifos nossos). Interessante notar que o mesmo artigo em que a doutrina se baseia para mostrar que o povo é o sujeito da representação política, pois soberano, foi empregado pelo Ministro Peluso, em sentido inverso. Desprezando o claro conteúdo que afirma serem os deputados representantes do povo, utiliza-se tão somente do método eleitoral para justificar suas ideias. Para ele, o dispositivo constitucional em tela permite inferir que "no próprio seio do conteúdo significativo da expressão 'sistema proporcional', está o primado dos partidos políticos e sua consequente titularidade sobre as cadeiras conquistadas na eleição". Não foi a única oportunidade na qual se percebe uma desconexão entre a premissa inicial e a conclusão dela auferida. Em momento ulterior, o Ministro se apoia nas lições de M. HERMAN SALEM CAGGIANO, que constatam a sobrepujança do partido na democracia patrocinada por estes, para extrair daí sua conclusão de que o parlamentar é mero depositário do mandato, que pertence ao partido. Não resta dúvida quanto à relevância e essencialidade da figura do partido na democracia hodierna. Nisso são concordes ambas correntes. Porém isso não permite se inferir que o mandato pertence ao partido. Salvo melhor juízo, a renomada autora, exímia estudiosa da representação política, não parece compartilhar de posições que promovam o mandato imperativo. TSE, Consulta N. 1.398/DF, rel. Min. Celso Asfor Rocha, 27.03.07, DJ 08.05.07. Cf. M. HERMAN SALEM CAGGIANO, A fenomenologia dos trânsfugas no cenário político-eleitoral brasileiro, cit., p. 227-230, na qual reafirma sua posição, em linha coerente com a adotada desde sempre quando da análise da natureza do mandato. V. também comentários no capítulo inicial desse estudo no tópico Teoria da Representação.

${ }^{455}$ M. HeRman SAlEM CAGgiano, A fenomenologia dos trânsfugas. O cenário político-eleitoral brasileiro, São Paulo, CEPES, 2006. 
é devido, parece carecer de precisão conceitual a afirmação do Ministro Peluso segundo a qual o parlamentar é o "representante do ideário político em cujo nome foi eleito". Ao contrário, a representação política tem outra natureza: em sua essência, requer que o povo seja representado. Quem deve se sentir representado é o eleitor e não o partido - tampouco a ideologia é representada. Mesmo que se considerem consistentes os conteúdos programáticos de alguns dos partidos brasileiros e se ignore o fenômeno da personalização política, o voto não é dado às ideias: é dado pelo povo para quem o representa. Por vezes, a motivação do voto pode ser atribuída às ideias de um candidato, à filosofia do partido ou ainda por mera simpatia pessoal do eleitor com o eleito. Mas, repita-se: vota-se no representante do povo, diz o texto constitucional. Ainda que a filiação seja condição de elegibilidade, não se pode inferir daí que é o partido que representa o povo. Quem o representa é a pessoa do candidato eleito, que será a voz deste no parlamento. Somente à pessoa natural do eleito é possível se atribuir a responsiveness, conforme estudado no primeiro capítulo.

Todavia, não foi essa a conclusão do excelentíssimo Ministro Asfor Rocha, pois, conforme suas próprias palavras: “Ao meu sentir, o mandato parlamentar pertence, realmente, ao Partido Político (...)",456. Agregou outras justificativas para seu sentimento, como o fato da importância dos votos dos partidos para alcance do número de votos do candidato para sua eleição, a necessidade da máquina partidária para o custeio das campanhas e o alto volume do dispêndio eleitoral. Procurou demonstrar, ainda, com fundamento nos artigos 108, $175 \S 4^{\circ}$. e 176 do Código Eleitoral ${ }^{457}$, a propriedade dos votos pelos partidos, uma vez que decorre do texto legal, por exemplo, que, em caso de inelegibilidade decretada pós-eleição ou cancelamento do registro do candidato, seus votos serão computados ao partido e não desprezados. Indo mais além, refuta o Ministro Asfor Rocha ser a assertiva uma criação original ou abstrata da interpretação jurídica, descolada da norma positivada. Para ele, é justamente no art. 108 do Código Eleitoral que se

${ }^{456}$ TSE, Consulta N. 1.398/DF, rel. Min. Celso Asfor Rocha, 27.03.07, DJ 08.05.07.

457 Corroborando o argumento do Ministro Celso Asfor e indo mais além, o Ministro Peluso nega o argumento de que não há previsão no ordenamento que permita propugnar-se a fidelidade partidária. Acresce aos artigos supramencionados outros dispositivos infraconstitucionais, tais como o art. 11, III, da Lei das Eleições (Lei N. 9504/97), que traz a exigência da prova de filiação partidária, bem como o art. $2^{\circ}$. do Código Eleitoral, que prevê: "Todo poder emana do povo e será exercido em seu nome, por mandatários escolhidos, direta e secretamente, dentre candidatos indicados por partidos políticos nacionais, ressalvada a eleição indireta nos casos previstos na Constituição e leis específicas”. O Ministro se ateve especificamente na parte do dispositivo que prevê que os mandatários são escolhidos dentre os candidatos indicados por partidos políticos'. Adiciona também os arts. 87 e seguintes da Lei N. 4.737/65 que repisam a exigência da filiação como condição de elegibilidade. Cf. TSE, Consulta N. 1.398/DF, rel. Min. Celso Asfor Rocha, 27.03.07, DJ 08.05.07. 
positivou a dependência do mandato ao partido político, autorizando-se, assim, a deduzir que os candidatos são eleitos com os votos do partido, pois aos partidos é que são dados os votos, segundo a norma constante do art. $175 \S 4^{\circ}$. do Código Eleitoral ${ }^{458}$.

Por essa lógica, o povo, soberano nos termos do primeiro dispositivo de nossa Carta Maior, teria transferido sua soberania ao partido, que seria então seu representante. Pois afinal, como reafirma o excelso Ministro Celso Rocha, "indevida (e mesmo ilegítima) a afirmação de que o mandato pertence ao eleito".

O Ministro Celso Rocha recuperou também a teoria funcionalista, por oposta à estruturalista - no intuito de compreender as finalidades das normas e do ordenamento. Frisou que as Cortes devem abandonar a visão positivista tradicional, “certamente equivocada". Estariam nossos Tribunais tomando rumos novos? É o que se depreende do voto em exame. Como ensina M. Herman SAlem Caggiano, a posição anterior da Corte Eleitoral visava preservar diversos institutos democráticos, tais como: a autonomia partidária, excluindo o exame de questões internas aos partidos da competência da justiça eleitoral; a natureza do mandato, como livre; a perda do cargo nas Mesas Diretoras nas hipóteses legais, mas nunca a perda do mandato; a retomada da vaga apenas em caso de morte ou renúncia do Deputado. De fato, em 1971, a Lei Orgânica dos Partidos Políticos (Lei N. 5682/71), que trazia dispositivo sancionador sobre condutas infiéis aos partidos, não encontrava receptividade na Justiça Eleitoral, que, diante de "inúmeras representações partidárias ensejando a perda do mandato do membro infiel", atuou de forma a evitar o mérito e afastar as penalidades ${ }^{459}$.

\subsubsection{Os votos convergentes pró-fidelidade no TSE}

Em análise do voto do Ministro Marco Aurélio na Consulta N. 1.398 do TSE, este praticamente não acrescentou novos elementos à argumentação do relator, mas ressaltou sua indignação com a possibilidade de um Deputado que alcançou 38 mil votos não ter sido eleito, à vista de outro que logrou sucesso com apenas 11 mil votos. Se o sistema eleitoral não proporciona os efeitos desejados - segundo o entendimento do Ministro - não seria o Judiciário impedindo a troca partidária que solucionaria tal problema

\footnotetext{
${ }^{458}$ Note-se que tal linha de argumentação sempre tem por base o mandato eletivo proporcional. Em seu voto, o Ministro Peluso afirma reiteradamente que no sistema proporcional há primazia dos partidos sobre a pessoa dos candidatos. TSE, Consulta N. 1.398/DF, rel. Min. Celso Asfor Rocha, 27.03.07, DJ 08.05.07.

${ }^{459}$ M. HeRman SAlEm CAGGIANO, A fenomenologia dos trânsfugas. O cenário político-eleitoral brasileiro, cit.
} 
e, ainda que o resolvesse, não se estaria empregando a forma correta e prevista pelo ordenamento para alteração do sistema eleitoral vigente.

De sua feita, o efusivo e emblemático o voto do Ministro Cezar Peluso mostra como é possível obter nos mais diversos pensamentos jurídicos, uma maneira de fundamentar a sua opinião ${ }^{460}$. Seu raciocínio se inicia com Stuart Mill, que justifica o governo representativo pela impossibilidade da participação pessoal de todos e extrai a conclusão de que "o tipo ideal de um governo perfeito só pode ser o representativo" ${ }^{461}$.

Discorrendo ainda sobre a representação política, enxerga o Ministro Peluso um "duplo vínculo" a permear o mandato parlamentar. O primeiro, de caráter popular, refletindo o princípio que todo poder emana do povo e, o segundo, de índole partidária, dado que a intermediação inerente à representação popular se deve à condição constitucionalmente proporcionada aos partidos.

Dentre os métodos eleitorais que suportam a formação da representatividade, encontra-se o proporcional, que por comparação ao majoritário, é, segundo o Ministro, aquele que tem como principal característica retratar a real proporção das correntes sócio-ideológicas. Atribui-se a cada facção um número proporcional de vagas aos votos por estas obtidos, objetivando um fiel quadro dos anseios sociais, mesmo tendose em conta que no Brasil, tem-se uma fusão ímpar ${ }^{462}$ do escrutínio uninominal em sistema de listas abertas com o sistema proporcional, onde o voto se dá a candidato individual, mas é contabilizado para o partido.

Relembrando Duverger, Sartori, Canotilho e Assis Brasil, o Ministro Peluso ressaltou reiteradamente o papel primordial da mediação partidária para a concretização da democracia representativa e a visceral dependência do sistema proporcional da figura dos partidos. Destacou, igualmente, o fato de certos candidatos a Deputado terem sido eleitos por determinado partido com número de votos inferiores ao outros candidatos que, sob outra legenda, não lograram êxito, por causa do quociente eleitoral. Atribuiu, com certa insegurança, à transmigração a causa da debilidade dos partidos brasileiros $^{463}$. Ao mesmo tempo em que, ao transcrever Luís VIRGILIO AFONSO DA

\footnotetext{
${ }^{460}$ Disso também decorre a imprescindível necessidade de contornos para a liberdade de interpretação que se apresenta nesse estudo. É, ademais, um alerta aos perigos da retórica que estabelece relações de causa e consequência para fatos totalmente divorciados.

${ }^{461}$ Cf. voto do Min. Cezar Peluso, TSE, Consulta N. 1.398/DF, rel. Min. Celso Asfor Rocha, 27.03.07, DJ 08.05.07.

${ }^{462}$ Cita-se a Finlândia como exemplo páreo ao nacional.

${ }^{463}$ Como é de conhecimento comum, a proliferação dos partidos chamados de "nanicos" se deve também ao fato da melhor chance que um determinado candidato pode eventualmente possuir se concorrer por alguma dessas legendas. Isso ocorre, pois, utilizando-se da lógica do sistema proporcional e do quociente eleitoral
} 
SILVA, quando este afirma que é pouco usual um eleitor votar por simpatia pessoal, não deixou o Ministro de fazer a ressalva em nota de rodapé, da percepção deste autor, de que isso não é regra no Brasil, onde predomina a campanha pessoal.

O Ministro Peluso colocou interessante indagação a respeito do alcance do vínculo estabelecido entre partido e candidato: "Esgotar-se-ia no momento das eleições, no ato da proclamação dos eleitos, na sua posse, ou pressuporia liame mais sólido entre o candidato e a agremiação política pela qual se elegeu?" Naturalmente, a questão não possui resposta imediata, tanto que o Ministro Peluso não apresentou uma solução pronta. Ao invés, recuperou discussão travada nos anos cinquenta, tendo como protagonista o Ministro Victor Nunes Leal. Curiosamente, o saudoso Ministro Leal defendeu arraigadamente a posição de que o Deputado representa o povo, ainda que a partir de critério partidário. Porém, o Ministro Peluso não compartilhou de sua opinião. Reafirmando seu reconhecimento da importância dos partidos no sistema político nacional, propõe alterar a célebre frase do Ministro Nunes Leal - para quem "o Deputado representa o povo, embora escolhido pelo critério partidário", reflexo da necessidade do sistema representativo - para a seguinte afirmação: "o Deputado representa o povo, porque escolhido pelo critério partidário". Para o Ministro Peluso, o candidato adere a um programa ao qual defenderá representando o partido nas eleições. Novamente aparecem sinais da "partidocracia", ou, como profere SÉRGIO RESENDE DE BARROS, a "politicatura" ${ }^{464}$. Veja-se como o partido se desloca da posição de instrumento viabilizador do sistema eleitoral para a razão maior de ser deste. Não obstante, o Ministro Peluso previu que "entendimento diverso implicaria o completo esvaziamento da função sistêmico-representativa dos partidos" 465 .

Toda a linha argumentativa traçada, enfim, recai na mesma conclusão dos outros votos pró-fidelidade: o mandato deve pertencer ao partido, como lógica decorrente do sistema proporcional e da essencialidade dos partidos. Fica a questão: o que, então, ocorreria no sistema majoritário? O mesmo ponto foi levantado pelo Ministro Carlos Ayres em seu voto: "Vossas Excelências parecem limitar os votos à situação de Deputados

que lhe é ínsito, pode, o candidato filiado a uma legenda pouco expressiva, com menor número de votos que seu rival de partido tradicional e com grande número de filiados, obter a vaga parlamentar que de outra maneira não teria sucesso. Cf. voto do Min. Cezar Peluso, TSE, Consulta N. 1.398/DF, rel. Min. Celso Asfor Rocha, 27.03.07, DJ 08.05.07.

${ }^{464}$ S. RESENDE DE BARROS, Contribuição dialética para o constitucionalismo, cit., p. 65.

${ }^{465}$ TSE, Consulta N. 1.398/DF, rel. Min. Celso Asfor Rocha, 27.03.07, DJ 08.05.07. 
Federais, pelo sistema proporcional". Não houve debate sobre este ponto, tampouco qualquer resposta à questão nesse julgamento. Nem do próprio Ministro ${ }^{466}$.

O Ministro Peluso combateu as teses contrárias à sua - presentes, principalmente, em decisões precedentes das Cortes - refutando possíveis argumentos contrários à fidelização ao partido: inicialmente, atacou a teoria pela qual apenas ao partido cabe sancionar a quebra da fidelidade, embasada no artigo 17, §1 ${ }^{\circ}$., da Carta Magna; depois, negou a assertiva de que a perda do mandato apenas se viabilizaria com alteração constitucional e o resguardo do direito de contraditório; e, por fim, desdenhou do reiteradamente mencionado fato da Constituição vigente, ao contrário da anterior, não prever a possibilidade da perda do mandato em razão da infidelidade partidária, listando em rol taxativo as causas de perda do mandato eletivo. Citou, como exemplo de tese doutrinária oposta ao seu entendimento, a de J. AFONSO DA SiLVA, para quem não só a Constituição não admite como veda a perda do mandato - previsão extraída do artigo 15, $\mathrm{CF} / 88$, segundo o jurista. Os contra argumentos do Ministro Peluso, em seu próprio magistério, não se fundaram somente nas relações internas entre o partido e seus afiliados. A Consulta proposta trataria de "fato externo" da mudança partidária, extrapolando questões interna corporis dos partidos. Haveria "outro fundamento, (...) à luz da relação entre o representante e o eleitor, intermediada pelo partido". Afere-se, segundo o magistrado, "a fidelidade ao eleitor" ao se averiguar a legitimidade do mandato representativo proporcional. Nesse ponto, o Ministro Peluso reforçou sua convicção de que as vagas pertencem ao partido, parafraseando o Ministro relator, ao ressaltar a "irrelevância absoluta da circunstância de já não constar, do ordenamento vigente, nenhum texto expresso a respeito". Evocou, igualmente ao seu colega, a interpretação sistêmica, baseada na força normativa dos princípios.

Novamente se cai na falácia de que se a filiação é requisito de elegibilidade, a consequência seria a preservação da vaga ao partido. Ou seja, o partido não é mais o instrumento intermediário, mas passa a ser detentor do mandato, porque se apresentou como meio viabilizador da relação entre o candidato e o eleitor. É o que deflui do raciocínio transcrito.

\footnotetext{
${ }^{466}$ De fato, toda lógica da tese pró-fidelidade se baseou nos princípios do sistema proporcional, mormente ao se predizer que o mandato pertence ao partido, porque os votos são atribuídos a este e não ao eleito. Como esse raciocínio não se aplicaria ao sistema majoritário, causou estranheza ao Ministro Carlos Britto, que esse fosse o pilar da tese majoritária. Cf. TSE, Consulta N. 1.398/DF, rel. Min. Celso Asfor Rocha, 27.03.07, DJ 08.05.07. A extensão da exigência de fidelidade partidária ao Presidente da República, Governadores, Prefeitos e seus respectivos Vices, bem como a Senadores, todos eleitos pelo sistema de votação majoritária somente viria com a resposta do TSE à Consulta N. 1407. TSE, Consulta N. 1.407, rel. Min. Carlos Ayres Britto, 16.10.07, DJU de 28.12.07.
} 
Retomou o Ministro Peluso o argumento de não-sanção, dizendo tratar-se "do reconhecimento da inexistência do direito subjetivo autônomo ou de expectativa de direito autônomo à manutenção pessoal do cargo". Com isso, procurou afastar a norma prevista no art. 55 da $\mathrm{CF}$, por este relacionar atos ilícitos sancionáveis. "A mudança de partido não é ato ilícito”, enfatizou o Ministro. Fez a correta - mas insuficiente - ressalva de que a mudança significativa de orientação programática do partido abre exceção, assim como a perseguição política, deixando de notar que os programas dos partidos, como já se pontuou, são demasiadamente amplos em prol de maior abrangência eleitoral. Além do mais, gera situações de difícil comprovação fática. Constata-se em alguns dos votos majoritários dos Ministros do TSE no julgamento apresentado ${ }^{467}$, o posicionamento segundo o qual não se está ferindo a liberdade de associação: o parlamentar pode filiar-se e desfiliar-se à sua vontade. A perda do mandato não se daria por sanção, por não ser ato ilícito. É apenas imoral. É uma "infração à probidade e à moralidade administrativas e públicas", considerou o Ministro Peluso.

Algumas observações devem ser colocadas quanto a esse ponto. Primeiramente, em se admitindo que o mandato fosse do partido, não se haveria de cogitar de perda deste pelo parlamentar. Por ora os votos trilham esse caminho, mas logo voltam a falar em perda do mandato eletivo. Observa-se nesse raciocínio uma inconsistência conceitual quanto à natureza do mandato, exatamente porque ele não pode ser propriedade de alguém - o mandato é tão somente exercido pelo representante do povo. Em segundo lugar, parece ser falaciosa a afirmativa de que não se trata de sanção. Se há infração (à probidade e à moralidade) e não apenas desrespeito ao eleitor, a forma de impedir os infratores de comportamento antijurídico é através da punição. A perda do mandato, ainda que revestida de perda do direito subjetivo de conservação do mandato, não seria outra coisa senão uma punição ou sanção. Tanto o é que, em se tratando da exceção à perda do mandato estabelecida nos casos de mudança de orientação programática do partido, propôs-se que sancionado com a perda da vaga no parlamento seria o partido e não o parlamentar, que então a carregaria consigo para futura legenda ${ }^{468}$. Retórico também o

${ }^{467}$ TSE, Consulta N. 1.398/DF, rel. Min. Celso Asfor Rocha, 27.03.07, DJ 08.05.07.

${ }^{468}$ TSE, Consulta N. 1.398/DF, rel. Min. Celso Asfor Rocha, 27.03.07, DJ 08.05.07. Nos termos do Ministro Peluso: "E, porque é o partido que, em tais hipóteses, terá dado causa ao rompimento daquela relação complexa, por alteração superveniente de sua linha político-ideológica ou pela prática odiosa de perseguição, será ele, não o candidato eleito, que deverá suportar o juízo de inexistência do direito subjetivo à conservação do mandato em sua esfera jurídica." Como será observado após o julgamento do STF, quando das decisões dos casos concretos da perda do mandato por infidelidade partidária, reiteradamente se fala em pena ou sanção ao trânsfuga.V. e.g., Petição N. 2759/DF, onde o Ministro Ricardo Lewandowski propõe a "aplicação dessas sanções, até por razões pedagógicas", ao se referir à perda do mandato do parlamentar que se 
entendimento de que não se fere a liberdade de associação ${ }^{469}$. Se a mudança de legenda importa qualquer prejuízo ao parlamentar é evidente que, em não havendo previsão legal expressa em nível constitucional, tolhida está sendo sua liberdade. Novamente, não se defende aqui que todas as trocas até hoje observadas apresentaram motivos altivos e éticos. Apenas que, conforme será enfatizado constantemente, não se pode, em uma democracia, mudar as "regras do jogo", empregando-se os termos de N. BoBBIO, relembrados pelos próprios Ministros. Por fim, nota-se que prevaleceu nos votos vencedores o argumento da "traição": quem trai, dá causa à perda do mandato. Estabeleceu-se uma estranha correlação entre a causa - traição - e a consequência - perda do mandato - porém sem querer se admitir qualquer natureza de sanção, de acordo com os arrazoados dos Ministros citados. Justificou-se toda necessidade de preservação do mandato do partido com o intuito de proteger o voto do eleitor. Esse argumento tem como única premissa que houve uma traição. Traição a uma ideologia vaga e um programa inconsistente, diante de um eleitor, em que grande parte vota nas pessoas e não em partidos. E se o partido muda de ideologia, realizando coalizões visando resultado eleitoreiro, ora votando a favor do governo, ora como oposição, por simples barganhas políticas? Não é também uma traição ao eleitor? $\mathrm{Na}$ lógica de traição ao eleitor, as coalizões também deveriam ser auferidas. Nesse instante, nada mais oportuno que o comentário de Luís VIRGILIO AFONSO DA SILVA:

\footnotetext{
"entender que a liberdade dos partidos em se aliar a outros partidos é uma injustiça, uma traição a vontade dos eleitores, é um pensamento com efeitos semelhantes à defesa de uma nova adoção do mandato imperativo." 470
}

Na mesma toada dos votos que lhe precederam, o Ministro Carlos Ayres Britto retomou os mesmos argumentos, ao afirmar a necessidade de respeito à vontade do soberano. E qual é essa vontade de fato? Será que a perplexidade pela mudança de partido revelada pelo Ministro Peluso, que refutou possuir preocupação exclusiva com o partido, mas antes com prejuízo aos eleitores, é compartilhada pelo povo?

desfiliara do partido, migrando a outra legenda. TSE, Petição N. 2.759 - Classe 18 . - DF, rel. Min. Arnaldo Versiani, 10.03.08, DJE 24.04.09.

${ }^{469}$ Frise-se que a liberdade de associação é um direito fundamental constitucional garantido pelo art. $5^{\circ}$, inc. XXII, Constituição Federal da República do Brasil de 05.10.88.

${ }^{470}$ L. VIRGÍlIO AFONSO DA SILVA, Interpretação constitucional e sincretismo metodológico, in L. VIRGÍLIO AFONSO DA SILVA (org.) Interpretação constitucional, São Paulo, Malheiros, 2005, p. 145. 


\subsubsection{Como os eleitores veem a troca de partidos?}

Conforme informações obtidas na página do Senado Federal na internet, diversas pesquisas a respeito foram realizadas no passado. Em 1994, o IUPERJ realizou enquete na cidade do Rio de Janeiro: 74\% dos eleitores escolhem seus Deputados Federais independentemente do partido. Em 1996, o IBGE apontou que 68\% dos entrevistados consideram o candidato mais importante do que o partido, na hora de votar. ${ }^{471}$ Dados que validam a percepção que a tese da personificação do candidato predomina factualmente.

Em relação a eventual incômodo que a infidelidade partidária causa à sociedade, temos o seguinte quadro. Em janeiro de 2003, pesquisa efetuada nas principais capitais do País pelo Instituto Brasmarket-Análise e Investigação de Mercado, demonstrou que quase a metade do eleitor brasileiro não concorda com o instituto da fidelidade partidária. Dos 2.637 eleitores consultados, quase metade dos entrevistados (49,5\%) se manifestou contra o conceito básico da fidelidade partidária. Conforme relata o texto, "para os eleitores pesquisados, o mandato é dos eleitores e dos eleitos, e, por isso, os políticos com mandato só devem acatar as orientações partidárias se concordarem com elas, o que lhes dá o direito de mudarem de partido sem a perda dos cargos eletivos" ${ }^{472}$. Do lado minoritário, 36,9\% dos pesquisados se manifestaram favoravelmente às regras atuais de fidelidade partidária, inclusive quanto à expulsão do partido. Igualmente, propuseram mudança nas regras atuais para a perda do mandato.

Em sentido divergente, estudos apresentados pelo Senado Federal trazem outra pesquisa sobre o tema, realizada pelo mesmo Instituto entre 2001 e 2002 e que revelou que " $65,7 \%$ dos entrevistados apoiavam mudanças nas regras, com a decretação de perda dos mandatos dos políticos que não seguissem a orientação de seu partido nas votações ou que mudassem de legenda após eleitos" ${ }^{473}$. Os estudos seguem ainda mostrando que para os eleitores, a migração revela a falta de identidade partidária, o que se percebe no momento das eleições, "pois não existe identificação do candidato com partidos e programas e o eleitor acaba votando no indivíduo de sua preferência" ${ }^{474}$. Trata-se do

\footnotetext{
${ }^{471}$ E. CRUXÊN MACIEL, Fidelidade partidária - um panorama institucional, cit.

${ }^{472}$ E. CRUXÊN MACIEL, Fidelidade partidária - um panorama institucional, cit.

473 Tribuna da Imprensa On Line, Pesquisa mostra que eleitor é contra a fidelidade partidária, 2003, disponível (on line) in www.tribuna.inf.br/anteriores/2003/marco/07/noticia.asp?noticia=politica03, [15.10.07].

${ }^{474}$ E. CRUXÊN MACIEL, Fidelidade partidária - um panorama institucional, cit.
} 
fenômeno da personalização da política, presente em sistemas políticos com partidos frágeis e ideologias inconsistentes.

Em justificativa à falta de engajamento ou participação política aparece a falta de responsabilidade do representante parlamentar perante o eleitorado que o elegeu, como uma das causas do baixo índice de confiança da população, quanto ao desempenho dos políticos eleitos. O IBOPE, em pesquisa do índice de confiança social realizada em 2009, apontou que dentre 22 instituições do país, as duas com maior descrença da sociedade são o Congresso Nacional e os partidos políticos ${ }^{475}$. Na linha evolutiva da confiança nos partidos políticos desde 1989, a desconfiança subiu de 70 pontos em 1989 para 88 pontos em $2005^{476}$.

A verdade que se configura demonstra que nem o sentimento dos ilustrados Ministros, nem pesquisas por amostragem conseguem retratar a real intenção popular. Somente via eleições ou através dos instrumentos de participação direta é que se poderia aferir qual a verdadeira vontade do povo soberano. É por intermédio do pleito eleitoral periódico que o povo se manifesta, podendo nessa ocasião julgar o infiel e valorar o peso da mudança de legenda de seu candidato em relação ao seu sentimento de estar devidamente representado.

\subsubsection{O voto divergente no TSE}

Ao desenvolver sua linha de argumentação, o Ministro Carlos Ayres Britto provocou eloquente debate. Apesar de votar em prol da perda do mandato pela infidelidade partidária, chegou a afirmar que:

\footnotetext{
"se a perda do mandato por migração partidária, cancelamento partidário, significa sanção, o art. 55 da Constituição restará vulnerado porque esse rol é taxativo. Cumpre uma função ambivalente porque ao mesmo tempo é uma ameaça de castigo, mas é também uma garantia do parlamentar: a garantia de que não perderá o mandato senão nas hipóteses descritas pela Constituição".
}

\footnotetext{
${ }^{475}$ Ibope, Confiança nas instituições, disponível (on line) in www.ibope.com.br., [14.11.09]. O índice médio das 22 instituições nacionais avaliadas é igual a 60, de um máximo de 100. O Congresso e os partidos políticos auferiram, respectivamente 35 e 31 pontos. Pesquisa realizada pelo IBOPE entre 18 e 22 de agosto de 2005 que mediu a confiança da população brasileira nas instituições nacionais.

${ }^{476}$ Ibope, Confiança nas instituições, disponível (on line) in www.ibope.com.br., [14.11.09]. O índice de desconfiança na Câmara dos Deputados de aumentou de 63 pontos para 81pontos e a desconfiança no Senado subiu de 57 para 76 pontos, em um total de 100 pontos, ambos dados avaliados no período entre 2003 e agosto de 2005. A desconfiança nos políticos subiu de 81 para 90 pontos, entre 1989 e 2005.
} 
Na opinião do Ministro Cezar Peluso, a resposta a esse ponto já havia sido colocada. Para este, não se trata de sanção, por não ser ato ilícito. Com isso, pareceu o Ministro Carlos Ayres satisfazer-se. O mesmo não se deu com o Ministro Marcelo Ribeiro, autor do único voto divergente. Em seu ponto de vista, desconsiderou-se o fato de que, a existência de um rol fechado não deveria levar a uma interpretação extensiva, mas restritiva. E isso tem sua razão de ser, continuou o Ministro Ribeiro. Não pretenderia o constituinte ter um rol fechado não fosse para estabelecer as devidas garantias e respeitar princípios fundamentais como o da separação dos Poderes. É nítido que o Poder constituinte originário considerou por bem não prever a perda do mandato no caso de migração, seja por sanção, seja por inexistência de direito subjetivo. É claro também que não se trata de omissão involuntária, adicionou. E, apesar de concorde com a imoralidade da falta de fidelidade aos partidos, o Ministro Marcelo Ribeiro repetiu inúmeras vezes que não há norma na Constituição, nem no ordenamento, que diga que a migração implique perda do mandato. Foi saraivado por argumentos que deliciariam os pós-postivistas. Primeiramente, com a resposta do Ministro Marco Aurélio: "E precisaria de uma norma diante dos princípios consagrados pela Constituição Federal? Seria 'acaciano'." Posteriormente, acompanhou-lhe o Ministro José Delgado: "Há muito tempo, desde que o constitucionalismo foi instituído no ordenamento jurídico, temos princípios e postulados explícitos das cartas magnas. Tudo decorre do sistema"477.

Em contraponto aos que propugnaram uma interpretação mais aberta, nas contra razões do Ministro Marcelo Ribeiro, vislumbra-se a real mudança de posicionamento de nossas Cortes. Disse o Ministro, sarcasticamente: "causa-me estranheza o fato de a Constituição estar prestes a completar dezenove anos e esta ser a primeira vez que se proclama que há a aludida perda de mandato. Ou seja, demorou-se um pouco para perceber esse princípio." Reforçando essa percepção, citou precedentes específicos do STF, estudados em item anterior deste capítulo: os Mandados de Segurança 20.927 e 23.405. Recapitulando-se, no primeiro julgamento da fidelidade sob a égide da nova Carta, em 1989, o Ministro Moreira Alves recuperou o tratamento constitucional dado ao instituto da fidelidade partidária, relembrando que a sanção presente na Constituição de 1967 por força da Emenda 1/69, fora retirada pela EC-25/85 e assim mantida afastada pela Carta vigente. Isso significa, no entendimento então pronunciado, com base inclusive em uma interpretação teleológica, que seria simples e suficiente que o constituinte houvesse

${ }^{477}$ TSE, Consulta N. 1.398/DF, rel. Min. Celso Asfor Rocha, 27.03.07, DJ 08.05.07. 
previsto tal hipótese entre as causas de perda de mandato, inserindo novo inciso no rol do artigo 55 da Constituição Federal.

Tocando justamente o ponto que traz limites para o neoconstitucionalismo e para as propostas pós-positivistas, o Ministro Marcelo Ribeiro proferiu: "Não me parece haver espaço para invocar princípios implícitos quando a matéria foi tratada expressamente na Constituição anterior e (...) retirada da atual Constituição". Demonstrou, deste modo, a necessidade de haver limites à atividade interpretativa, sendo um deles exatamente a existência de norma reguladora do tema no ordenamento, prevendo as condutas ilícitas e indesejáveis e não obstando as desejáveis e lícitas.

Mas fato é que houve uma evolução da situação da época constituinte para os dias de hoje. Em 1985, o quadro que se apresentava era de partidos renascidos das cinzas, após um longo período autoritário. Nesse contexto, era desfavorável a manutenção de um Deputado em seu partido de origem. A legislação, além de permitir a migração partidária, de certa maneira a facilitava, sobretudo visando à sobrevivência de qualquer agremiação no cenário político, em direção ao pluripartidarismo. Nesse sentido editou-se a EC-25/85, retirando qualquer tipo de restrição a migração. Já nessa época, o eleitorado se mostrara desatento quanto aos partidos e à trajetória partidária de seus representantes. Por fim, os vínculos entre os Deputados e os partidos revelavam-se frágeis devido ao curto tempo de vida dos partidos, as suas origens elitistas, e, como visto, o sempre presente poder político regional e local inibindo a afirmação de um perfil nacional, além da realização de campanhas político-eleitorais fortemente individualizadas. ${ }^{478}$

De qualquer modo, a evolução histórica da democracia pátria, que traz consigo desdobramentos no sistema partidário, poderia justificar a necessidade de nova alteração da norma, mas não a supressão da forma prevista no ordenamento para promover essa mudança, como querem os adeptos da interpretação evolutiva.

${ }^{478}$ E. CRUXÊN MACIEL, Fidelidade partidária - um panorama institucional, cit. 


\subsection{O julgamento no STF}

\subsubsection{A subsunção do caso ao STF}

Com a materialização do entendimento do TSE sobre a questão da fidelidade partidária por meio da edição da Resolução N. 22.526/07, efetivada com base na resposta desta Corte à Consulta N. 1.398 formulada pelo PFL em 27 de março de 2007, era de se esperar uma corrida dos partidos políticos pela recuperação das vagas que perderam com a dança das cadeiras.

Poucos dias após a publicação da referida Resolução, em 03 de abril do mesmo ano, o PSDB-Partido da Social Democracia Brasileira, pleiteou que o Presidente da Câmara dos Deputados declarasse a vacância dos mandatos daqueles parlamentares que abandonaram a sigla anteriormente ao pronunciamento do TSE. O pedido repetiu as razões aduzidas pelo Tribunal em prol da devolução do mandato ao partido, acrescentando que considerava a conduta do trânsfuga atentatória à coisa pública e à vontade popular, com base no art. $3^{\circ}$. do Código de Ética e Decoro Parlamentar da casa. Assim, nomeou os sete Deputados Federais que trocaram espontaneamente de legenda entre as eleições de 2006 e 27 de março de 2007, requerendo ao Presidente Arlindo Chinaglia que declarasse vagos os cargos destes Deputados, convocasse e empossasse os respectivos suplentes em quarenta e oito horas, seguindo o rito do art. 239, do Regimento Interno da Câmara dos Deputados. O mesmo tipo de pleito foi colocado pelo PPS - Partido Popular Socialista, que havia perdido

alguns de seus parlamentares para outras legendas e solicitou ao Presidente da Câmara a reposição dos mandatos de Deputado Federal que teria obtido nas últimas eleições.

Em retorno aos pedidos administrativos efetuados, alegou o Presidente da Câmara, fundando-se em parecer da consultoria jurídica da casa, inexistir autorização legal para que a mesa da Câmara declarasse vagos os cargos e convocasse os suplentes para preenchê-los, uma vez que não se verificaria tal possibilidade no rol fechado do art. 55 e $56, \S 1^{\circ}$., CF/88, reproduzidos nos arts. 238 a 241 do Regimento Interno.

A recusa da Mesa da Câmara dos Deputados em atender o requerimento colocado pelos partidos ensejou a provocação da Corte Suprema de maneira imediata e simultânea pelos partidos PPS, PSDB e DEM, os principais interessados em reaver as vagas perdidas de parlamentares que migraram em direção à base governista. 
Entendendo haver ilegalidade perpetrada pelo Presidente da Câmara dos Deputados por descumprimento de decisão da Justiça Eleitoral, foram impetrados os mandados de segurança de números 26.602, 26.603 e 26.604, respectivamente pelo PPS, PSDB e DEM. As demandas visavam preservar liminarmente direito líquido e certo de obtenção dos mandatos, que a Corte Eleitoral Superior havia determinado como sendo dos partidos, com a declaração de vacância por renúncia presumida do parlamentar ao mandato eletivo. Em outros termos, os partidos pretendiam manter as vagas na ocorrência de desfiliação do Deputado, uma vez que essas foram conquistadas pelos mesmos no sistema proporcional, no entender dos impetrantes.

Intimado a se manifestar, a autoridade impetrada reiterou seu posicionamento, segundo o qual não há amparo na Constituição ou na lei para atender ao pedido dos impetrantes. Diante da Resolução do TSE, manifestou entendimento no sentido de que esta não se impõe sobre a Câmara dos Deputados, uma vez que desprovida de executoriedade.

O litisconsórcio passivo, composto pelos Deputados que trocaram de legenda e que tiveram seus mandatos sujeitos ao perdimento, contestou o pedido dos autores, apresentando argumentos similares, que podem ser resumidos nos seguintes:

1) Existência de prévia manifestação do STF sobre a inexistência de hipótese de perda do mandato por infidelidade partidária em nosso ordenamento. Rol taxativo do art. $55 \mathrm{CF} / 88$;

2) Impossibilidade de o Judiciário emendar a Constituição admitindo nova hipótese de perda do mandato;

3) Inaplicabilidade da tese da renúncia tácita ou presumida ao mandato, por falta do elemento volitivo de abandonar o exercício;

4) Adoção pelo ordenamento pátrio do princípio segundo o qual regra que restringe direitos deve vir expressa e só abrange os casos que especifica. Portanto, não pode o Judiciário, por meio de interpretação ampliativa, restringir o direito dos parlamentares de livre exercício do mandato, alterando a vontade do constituinte originário;

5) Incompetência do TSE para se pronunciar sobre matéria de reserva constitucional, não tendo sua Resolução força vinculante;

6) Inexistência no estatuto dos partidos impetrantes de previsão 
punitiva para a desfiliação partidária;

7) Trocas partidárias efetuadas dentro das exceções previstas na Resolução do TSE, referentes à perseguição política do partido de origem ou alteração da ideologia e conduta do partido;

8) No caso específico de alguns Deputados egressos do PPS, suas desfiliações teriam se processado em face da fusão do PPS com o PNM e o PHS. Alegaram, assim, desobrigação em permanecer na agremiação que, devido à fusão, teria sofrido mutação em seu conteúdo programático e ideológico.

O julgamento dos três mandados se processou de forma conjunta. Tomase como base para estudo o MS 26.603 por conter o voto condutor da corrente majoritária no STF (voto proferido pelo Ministro Celso de Mello). Inicialmente, quanto ao pedido de liminar formulado pelo impetrante, pronunciou-se o Ministro relator dessa ação negandolhe o provimento. Fundamentou o relator sua decisão na jurisprudência até então formada pelo STF, em especial o MS 20.916, que recusou a vacância dos mandatos dos parlamentares trânsfugas.

Em sequência, coube à Procuradoria Geral da República manifestar-se nos autos, posicionando-se sobre a questão em tela.

\subsubsection{O parecer do Ministério Público Federal}

Dentre todas as fases e instâncias percorridas na definição da questão da fidelidade partidária iniciada no ano de 2007, em nenhum outro momento se depara com uma manifestação tão rica e esclarecedora quanto o parecer emitido pelo Procurador-Geral da República nos autos do mandado de segurança $26.603{ }^{479}$. Mormente para aqueles que compartilharam de seu posicionamento contrário à punição com a perda do mandato ao parlamentar infiel, suas proposições vieram revestidas de lógica e coerência com o ordenamento vigente. Deter-se na investigação detalhada dos elementos que o documento

${ }^{479}$ Parecer N. 3250/PGR, Ministério Público Federal, in STF, Pleno, MS 26.603-DF, rel. Min. Celso de Mello, 04.10.07, DJE 19.12.08. 
elaborado pelo Ministério Público será tão importante quanto elucidar a matéria por meio da análise dos votos da Suprema Corte.

Destarte, procedeu o parecista ao exame das preliminares de ausência de interesse e ilegitimidade ativa do impetrante, afastando-as de plano. O mesmo não se deu com a preliminar de não conhecimento do writ diante da necessidade de produção de provas, no entender do douto Procurador-Geral. Fundando-se na própria previsão estabelecida pelo TSE na Consulta N. 1.398, segundo a qual há exceções para a mudança de legenda sem a perda do mandato, apontou que devem ser apuradas mediante dilação probatória eventual perseguição do parlamentar pelo partido ou alteração na orientação ideológica do grêmio. Justamente as causas alegadas pelos litisconsortes passivos em sede de defesa do mandamus em exame, cujo deslinde, em observância aos princípios constitucionais da ampla defesa e do contraditório, representaria um empecilho ao deferimento da ordem demandada, conforme entendimento sumulado da Suprema Corte ${ }^{480}$.

No mérito, aduziu o Procurador-Geral, Antonio Fernando Souza, argumentos em diferentes searas. Relativamente à contraposição da decisão do TSE com a teoria da representação e seus efeitos para a democracia representativa, procurou demonstrar, tanto a preocupação com os desvios da representação política advindos da ruptura do mandato livre, quanto com o crescente poder dos partidos, que coloca em risco a própria democracia. Nesse sentido, recorreu a N. BOBBIO para relembrar que a democracia, na visão do autor, conforme visto no capítulo inicial deste trabalho, possui "déficits de legitimidade" provocados pelas "promessas não cumpridas" ${ }^{481}$. A partir dos ensinamentos de GIANFRANCO PASQUINO e GERHARD LEIBHOLZ apresentou a percepção da apatia do eleitorado perante "um divórcio significativo entre a sua vontade e valores e aqueles defendidos por seus representantes eleitos" 482. E de MAURICE DUVERGER, absorveu as críticas ao modo oligárquico de atuação e organização dos partidos políticos. Toda essa digressão é empregada para demonstrar que o fenômeno da infidelidade é antes um sintoma de um sistema político-partidário falido do que sua causa. Ao contrário, o Procurador aponta uma série de motivos para seu mau funcionamento. Causas estas que abrangem o sistema eleitoral proporcional, de listas abertas, o déficit de democratização

\footnotetext{
${ }^{480}$ STF, Súmula 625.

${ }^{481}$ N. BobBio, O futuro da democracia, trad. Marco Aurélio Nogueira, 10a . ed., Rio de Janeiro, Paz e Terra, 2006, p. 20.

${ }^{482}$ G. PASQUINO, Degenerazioni dei Partiti e Riforme Istutuzionali, Roma, Laterza ed., 1982; G. LEIBHOLZ, La Representazione nella Democrazia, Milão, Giuffrè, 1989, APUD Parecer N. 3250/PGR, Ministério Público Federal, in STF, Pleno, MS 26.603-DF, rel. Min. Celso de Mello, 04.10.07, DJE 19.12.08.
} 
interna dos partidos, o loteamento de cargos e funções públicas, a deficiência dos programas e ideologias partidárias e a baixa representatividade que os partidos apresentam perante os eleitores.

De outra face, caracteriza-se, na opinião do Procurador-Geral, praticamente "um mandato imperativo partidário de fato", motivado pela concentração de poder nas lideranças partidárias, pelas votações nominais, pela força de atração do Chefe do Executivo ao nomear cargos de primeiro escalão e definir aplicação do orçamento, pelo consequente clientelismo e patronagem, pelas liberações de recursos via emendas parlamentares e pela concessão de cargos públicos em troca de apoio político.

Estes elementos impregnam a cultura política de nosso país, agravam a crise de representação política e comprovam que a vinculação ao partido e a fidelidade do eleitor são decorrências de uma maior maturidade política. E que, portanto, pouca mudança se promoveria sem uma ampla reforma política, sendo mero apelo retórico a moralização da política pela proibição das trocas de legenda, enrijecendo o vínculo partidário. Ao contrário, como alertou Antonio Fernando, corre-se o risco de captura do processo eleitoral e parlamentar pelas lideranças dos partidos. Fenômeno este, que nenhuma relação guardaria com o Estado de Partidos ora estudado, mas sim com um "Estado oligárquico", um "personalismo democrático", com lembranças de um modo de exercício de poder típico do coronelismo.

Acrescentou aos argumentos que denominou de política constitucional, elementos de direito constitucional estrito ou positivado. Analisando a premissa majoritariamente sustentada pelos Ministros do TSE no recente julgamento da fidelidade, segundo a qual o sistema proporcional, orientado pelos quocientes eleitorais e partidários, determina a distribuição de vagas entre os partidos e não entre os candidatos mais votados, julgou o parecista ser esta visão equivocada.

Aduziu suas razões por meio de uma interpretação sistêmica do texto constitucional, avocando que todo poder político tem como fonte e limite o povo. Os meios de exercício da soberania popular são encontrados no artigo 14 da Carta Magna, que prevê o sufrágio universal, o voto direto, secreto e igual, além das iniciativas de participação direta por meio do plebiscito, do referendo e da iniciativa popular.

Embora se reconheça o papel imprescindível dos partidos na democracia hodierna, com sua função de tradução da vontade popular para a formação do poder, não se deve creditar a esses elementos a capacidade de tornar o mandato propriedade de uma 
agremiação política, sob pena de tornar os partidos políticos, ao invés de intermediários, fins em si mesmos.

Atacando um dos principais pontos do raciocínio predominante na Corte Eleitoral máxima, o Procurador ressaltou ser a filiação uma condição de participação no processo eleitoral e não pressuposto para exercício do mandato. Amparando-se no art. 45 $\mathrm{CF} / 88$, frisou serem os Deputados representantes do povo e não dos partidos, em consonância com a teoria do mandato representativo. Conforme estudado, o parlamentar eleito pelo povo não representa apenas os que o elegeram, configurando o mandato livre ou fiduciário, pelo qual, durante seu exercício, nem ao povo cabe retirá-lo de seu representante $^{483}$. Dessa lógica, infere-se também que se ao povo, detentor da soberania, não é dado poder de retirar o mandato do eleito, não seria ao partido autorizado cassar a qualidade de representante do povo ou a vincular os eleitos eternamente às suas ordens, pois estes se submetem tão somente à sua consciência. Não obstante, convivem, na democracia pelos partidos, sem quaisquer contradições, o mandato livre e a intermediação dos partidos para constituir a vontade política do povo.

Para fundamentar sua posição o parecista citou KonRAD HeSSE, que reafirma haver limites jurídico-constitucionais à vinculação do Deputado ao partido e constata que eventual separação ou exclusão do partido ou ainda passagem a outro "não tocam o mandato" ${ }^{484}$. Configura-se, desta forma, o mandato livre como condição necessária à democracia e cuja integridade deve prevalecer sobre quaisquer interesses de suas instituições, mormente os dos partidos políticos, que são, nesta visão, meros instrumentos operacionais desta, ainda que imprescindíveis à democracia hodierna.

Indo mais além, o parecer em exame traçou um paralelo com a recente história político-partidária na Itália, país que também sofre das mazelas da fragmentação partidária. Citou PIETRO VIRGA, para demonstrar que "a perda do mandato parlamentar por desligamento do partido não é uma consequência segura da representação proporcional”, pois "nenhuma norma consuetudinária ou punitiva poderá impor ao parlamentar, que se demitiu ou venha a ser expulso do próprio partido, que entregue o mandato político" ${ }^{485}$. Ao constatar que o mesmo nível de argumentação é adotado por parte da doutrina nacional,

483 A impossibilidade de revogação do mandato pelos eleitores, bem como o impedimento que dessem instruções aos parlamentares eleitos é orientação marcante da Constituição liberal francesa de 1791.

${ }^{484}$ K. Hesse, Elementos de Direito Constitucional da República Federal da Alemanha, trad. Luís Afonso Heck, Porto Alegre, Fabris, 1998, p. 446, APUD Parecer N. 3250/PGR, Ministério Público Federal, in STF, Pleno, MS 26.603-DF, rel. Min. Celso de Mello, 04.10.07, DJE 19.12.08.

${ }^{485}$ P. VIRGA, Diritto Constituzionale, 9a .ed, Milano, Giufrrè, s.a., p. 153, APUD Parecer N. 3250/PGR, Ministério Público Federal, in STF, Pleno, STF, Pleno, MS 26.603-DF, rel. Min. Celso de Mello, 04.10.07, DJE 19.12.08. 
repetiu o procurador os ensinamentos de SAMPAIO DÓRIA, que estão alinhados com a liberdade de proceder no exercício do mandato pelo parlamentar e sua decorrente irrevogabilidade $^{486}$.

Outro argumento central, apresentado pelo TSE no julgamento da infidelidade e duramente rechaçado pelo Procurador-Geral, foi a dedução de que o sistema proporcional vigente e sua previsão de aplicação dos quocientes eleitoral e partidário como critério para divisão das cadeiras implicam diretamente um vínculo imutável entre eleito e partido pelo qual se elegeu. Na época, declarou o parecista enfaticamente: "Se a regra valesse para Deputados haveria de valer também para os Senadores”. Não foi necessário aguardar muito tempo para que a Corte Eleitoral Superior estendesse a proibição à infidelidade quanto aos mandatos eletivos obtidos pelo sistema majoritário ${ }^{487}$, o que por si só, afastaria toda a lógica da relação vislumbrada entre sistema proporcional e direito à vaga do partido por ter este obtido os votos e os quocientes que estabeleceram o número de cadeiras.

Partindo do princípio constitucional da liberdade de associação, o Procurador-Geral construiu seu argumento em linha com os defensores da impossibilidade de perda do mandato por infidelidade. Assim, pontuou ser inadmissível extrair-se das entrelinhas do texto constitucional a penalidade proposta (ainda que os Ministros não considerassem a perda do mandato como sanção), sob pena de estar sendo violado o princípio da legalidade de toda função sancionatória, de um lado e, de outro, atentando contra a imunidade material dos parlamentares presente no art. 53 da Lei Maior e com isso afetando a liberdade e independência do Legislativo.

Embora os três principais argumentos aduzidos pelo parecista combatam frontalmente a posição majoritária dos Ministros de ambas as Cortes, não haveria de se olvidar da crítica à válvula de escape criada pela interpretação expansiva defendida pelos pós-positivistas. De fato, recuperou o Procurador-Geral o argumento reiterado dos Ministros, pelo qual a inexistência de previsão expressa no ordenamento de hipótese de

${ }^{486}$ S. DORIA, Direito Constitucional, Curso e Comentários à Constituição, $3^{\mathrm{a}}$.ed, São Paulo, Cia. Editora Nacional, 1953, p. 321-325, APUD Parecer N. 3250/PGR, Ministério Público Federal, in STF, Pleno, MS 26.603-DF, rel. Min. Celso de Mello, 04.10.07, DJE 19.12.08.

${ }^{487}$ A questão em tese versava: "Os partidos e coligações têm o direito de preservar a vaga obtida pelo sistema eleitoral majoritário, quando houver pedido de cancelamento ou de filiação ou transferência do candidato eleito por um partido para outra legenda?". A resposta do TSE foi afirmativa por unanimidade. Cf. TSE, Consulta N. 1.407, rel. Min. Carlos Ayres Britto, 16.10.07, DJU de 28.12.07. De outra face, foi formulada pelo Deputado Federal Ciro Lima Filho a Consulta que recebeu o N. 1.423 do TSE, na qual se indagava: "Se os Deputados Federais e Estaduais que trocaram de partido político que os elegeram e ingressarem em outro partido da mesma coligação, perdem seus respectivos mandatos legislativos?" Novamente a resposta do TSE foi unanimimente positiva. Cf. TSE, Consulta N. 1.423, rel. Min. José Delgado, 01.08.07, DJU de 28.08.07. 
perda do mandato diante da infidelidade não tem nenhum valor diante da magnitude da interpretação sistêmica. E indagou: "É possível extrair esse limite a partir da interpretação sistemática pretendida?”. De pronto, descartou qualquer resposta afirmativa e apresentou suas razões. Primeiramente, conforme pontuou o Procurador-Geral, não haveria de ser juridicamente legítima a interpretação que responde com sanção diante do silêncio normativo, que claramente, não se trata de mero esquecimento do constituinte. Ademais, não se pode pretender complementar judicialmente a obra constituinte, sob pretexto de preencher lacuna ideológica, querendo constituir o direito a partir do que deveria ter dito o constituinte quando não o fez, ou ao contrário, fez exatamente o oposto. Em segundo plano, não poderiam os estatutos e regimentos partidários, ao disporem sobre disciplina e fidelidade partidária, prever qualquer penalização que resulte na perda do mandato, pois, de acordo com a lição de J. AfONSO DA SILVA, a Constituição não só não permite a perda do mandato por infidelidade como também a afasta, ao declarar em seu art. 15, ser vedada a cassação dos direitos políticos. Admitem-se, tão somente as hipóteses de perda e suspensão indicadas expressamente.

E, por fim, o Procurador-Geral reforçou a impossibilidade de uma interpretação que contrariasse a vontade democrática e democratizante do constituinte de 1988, que teria optado por não recuperar o mandato imperativo surgido na Constituição do período militar e retirado do ordenamento três anos antes da promulgação da Carta democrática vigente, durante o período de abertura política e redemocratização pelo qual a nação passou. Quisesse o constituinte originário admitir a plausibilidade da perda do mandato a partir da desfiliação do eleito, teria expressamente previsto tal hipótese. A exata leitura do texto constitucional vigente define as causas da perda de mandato a se operar via decisão desconstitutiva, quais sejam: incompatibilidades, falta de decoro e condenação criminal definitiva. De outra face, as hipóteses restantes levam à declaração da extinção do mandato, conforme estudado no primeiro item deste capítulo ${ }^{488}$. Não se encaixando a infidelidade como nenhuma das causas de perda do mandato, advertiu o Procurador, que o juízo de conveniência de estabelecer-se nova hipótese de perda do mandato seria de competência do constituinte derivado, sendo exato que se deve respeito à reserva da Constituição para esta matéria ${ }^{489}$.

\footnotetext{
${ }^{488}$ Como hipóteses de perda do mandato aparecem os incisos I, II e VI do art. 55, CF/88 e como hipóteses de extinção, os incisos III, IV e V do mesmo artigo. V. Item 3.2 deste capítulo.

${ }^{489}$ Em suporte à assertiva trouxe considerações da Ministra Cármen Lúcia Rocha, que demonstram não só a questão dos limites de alteração, como também a importância da representação política para a democracia. De acordo com a Ministra, “A opção pelo sistema eleitoral é tarefa do constituinte, e a pormenorização dos
} 
Porém, seus argumentos em desfavor de uma interpretação expansiva não se esgotaram nos itens acima desenhados. Em contraposição àqueles que propagam o princípio da não fossilização da Constituição por meio da hermenêutica evolutiva, trazendo inclusive o exemplo da sistemática interpretativa norte-americana, o Procurador foi decisivamente combativo. Inicialmente, aclarou que nossa Constituição é jovem se comparada à americana que possui mais de dois séculos de existência. Adicionou que as Cortes nacionais haviam, até a Consulta N. 1.398 em exame, decidido reiteradamente pela não sanção do trânsfuga, mencionando as decisões já analisadas neste capítulo. Não restaria motivo para se identificar omissão do constituinte de 88 a ser preenchido por aplicação de princípios que promovam regras sancionatórias ao parlamentar. Recorre-se, neste ponto, às lições de Teoria Geral do Direito de $\mathrm{N}$. BoBBIO ${ }^{490}$, que desautorizam o intérprete a preencher eventuais lacunas impróprias deixadas pelo constituinte, decorrência, ademais, do equilíbrio dos poderes no Estado Democrático de Direito. Dois aspectos se ressaltam: a instabilidade institucional do direito e a legitimidade conferida pela separação entre a atividade legislativa e a atividade judicial. Ambos são cruciais para uma correta exegese ao se retratar um suposto ativismo judicial, que ultrapassa a "exatidão funcional de seu agir", empregando-se os termos do Procurador, que igualmente alertou para os riscos de eventual mutação constitucional, tomando de empréstimo os ensinamentos de KARL LOEWENSTEIN ${ }^{491}$.

seus paradigmas normativos é atribuição do Poder Legislativo, o qual terá como limite de sua ação a natureza mesma dessa competência. Não há de se pensar numa escolha por um ou outro sistema eleitoral, fundada exclusivamente no interesse dos partidos políticos, deixando-se em segundo plano o interesse maior, que é do cumprimento integral do sistema da representação, realizador, ou não, da Democracia." CÁRMEN LÚCIA ANTUNES ROCHA, O processo eleitoral como instrumento para a democracia, Resenha eleitoral, Florianópolis, v.5., n. 1., p.65-83, APUD Parecer N. 3250/PGR, Ministério Público Federal, in STF, Pleno, MS 26.603-DF, rel. Min. Celso de Mello, 04.10.07, DJE 19.12.08.

${ }^{490}$ N. BobBio, Teoria do Ordenamento Jurídico, $10^{\mathrm{a}}$. ed., trad. Maria Celeste C. dos Santos, Brasília, UNB, 1999, p. 144. Diz o autor: "As lacunas impróprias são completáveis somente pelo legislador; as lacunas próprias são completáveis por obra do intérprete."

491 "En la mutación constitucional, por otro lado, se produce una transformación en la realidad de la configuración del poder político, de la estructura social o del equilíbrio de intereses, sin que quede actualizada dicha transformación en el documento constitucional: el texto de la constitución permanece intacto. Este tipo de mutaciones constitucionales se da en todos los Estados dotados de una constitución escrita y son mucho más frecuentes que las reformas constitucionales formales. Su frecuencia y intensidad es de tal orden que el texto constitucional en vigor será dominado y cubierto por dichas mutaciones sufriendo un considerable alejamiento de la realidad, o puesto fuera de vigor." K. LOEWENSTEIN, Teoria de la Constitucion, trad. Alfredo Gallego Anabitarte, Barcelona, Editorial Ariel, 1976, p. 165. Considera-se mutação constitucional a alteração informal da Constituição, que lhe designa novos sentidos, "conteúdos até então não ressaltados à letra da LICC", seja por meio da interpretação, seja através da construção, ou pelos usos e costumes. Cf. RonAldo GALlo, Mutação constitucional, Jus Navigandi, Teresina, ano 7, n. 63, mar. 2003, disponível (on line) in http://jus2.uol.com.br/doutrina/texto.asp?id=3841., [05.05.2009]. V. também J. AfOnso DA SILVA, Aplicabilidade das Normas Constitucionais, 5 a ed., São Paulo, Malheiros, 2001. 
Em complemento à discussão acerca da hermenêutica constitucional, retoma-se a lição de KARL LARENZ - igualmente trazida pelo parecista do Parquet - pois esta toca de forma contundente o principal aspecto que se procurou pontuar durante todo o trabalho relativamente aos limites da interpretação constitucional. Afinal, na lógica da democracia, os tribunais, ao desempenhar tão relevante tarefa, que busca aplicar o direito superando o alcance restrito da letra da lei, não podem atuar sem fronteiras, sem barreiras que os façam adentrar terreno reservado a outro Poder, abalando a legitimidade das instituições democráticas. É por essa razão que se considera que K. LARENZ asseverou com exatidão que:

\begin{abstract}
"O limite do desenvolvimento do Direito superador da lei, levado a cabo pelos tribunais situa-se onde já não é possível uma resposta (...) com considerações especificamente jurídicas; em especial, portanto, quando se trata de questões de oportunidade ou quando seja requerida uma regulamentação pormenorizada que só o legislador pode encontrar, pois que só ele dispõe das informações para tal necessárias e de legitimação para isso.

O limite assim exposto, que resulta da divisão de funções entre atividade legislativa e administração da justiça, foi reconhecido também pelo Tribunal Constitucional Federal". 492
\end{abstract}

Com respaldo no constitucionalista alemão K. $\operatorname{HESSE}^{493}$, o ProcuradorGeral demonstrou que o autor também destaca os limites do intérprete judicial, que impedem o resultado da atividade hermenêutica de extrapolar as funções que lhe são constitucionalmente designadas. K. HESSE alerta - conforme bem lembrou o ProcuradorGeral - que o "direito não-escrito" não deve se contrapor à "constitution scripta", por mais que alterações no ordenamento sejam política e socialmente necessárias, sob o risco de se atropelar a norma maior do ordenamento e de desrespeito à máxima que prevê a vinculação do magistrado à Constituição.

Apesar de ter adotado posicionamento contrário à perda do mandato por infidelidade, Antonio Fernando Souza não deixou de reconhecer a premência de uma ampla reforma política, que inclua também a fidelidade partidária, como modo de, em conjunto com outras medidas, fortalecer o sistema partidário e com isso o regime democrático. Percebeu, inclusive, a tendência da Corte Suprema de revisão do posicionamento até então acolhido, como se mencionou na análise dos votos proferidos na ADI 1.351-DF no capítulo segundo deste estudo.

\footnotetext{
492 K. LARENZ, Metodologia da Ciência do Direito, trad. José Lamego, $3^{\mathrm{a}}$. ed., Lisboa, Fund. Calouste Gulbenkian, 1997, p. 607. O autor refere-se ao Tribunal Constitucional alemão.

${ }^{493}$ K. HESSE, Elementos de Direito Constitucional da República Federal da Alemanha, cit., p. 67-70, APUD Parecer N. 3250/PGR, Ministério Público Federal, in STF, Pleno, MS 26.603-DF, rel. Min. Celso de Mello, 04.10.07, DJE 19.12.08.
} 
Todavia, considerando-se que a adoção da infidelidade como causa da perda do mandato é matéria reservada à Constituição, propôs o Procurador que, na eventual alteração de orientação das Cortes, deve-se atentar à segurança jurídica. Surgem, novamente, as "regras do jogo" 494 , que não podem ser livremente alteradas penalizando a democracia. Entendeu o parecista que o novo entendimento não poderia ser aplicado senão para uma nova legislatura, ou que, então, fosse observada a anterioridade constitucional prevista no art. 16 da Carta Maior, dispositivo que visa, sobretudo, proteção à segurança jurídica e à estabilidade do Direito positivado.

Pelo todo exposto, pode-se concluir que o parecer fornecido pela Procuradoria-Geral da República, nos autos do MS 26.603, aplicado aos outros dois mandamus com objetos equivalentes, trouxe elementos essenciais para uma profunda averiguação do tema da infidelidade partidária. Preliminarmente, opinou pelo não conhecimento da ação. Subsidiariamente, não sendo este o entendimento do Supremo, entendeu que a ordem deveria ser denegada, restando, ainda, em caso de concessão, que seus efeitos se propagassem apenas na legislatura seguinte ou respeitado fosse o preceito da anterioridade da lei eleitoral. Em que pese a soberba fundamentação do parecer, a partir da análise dos votos dos Ministros do Supremo concedidos nos três mandados de segurança em tela, poderá se perceber que a posição majoritária divergiu do douto entendimento do Procurador-Geral. É o que se buscará demonstrar a seguir.

\subsubsection{A nova corrente majoritária no STF}

Em 04 de outubro de 2007 o Supremo Tribunal Federal encerrou a sessão de julgamento conjunta dos mandados de segurança de igual propósito (MS 26.602, 26.603 e 26.604), indeferindo os dois primeiros, deferindo parcialmente o último e decidindo, por maioria de $\operatorname{votos}^{495}$, pela perda do mandato do parlamentar infiel em prol do partido pelo

\footnotetext{
${ }^{494}$ N. BoBBIO, O futuro da democracia, cit., p. 77-78.

${ }^{495}$ A maioria foi formada pelos votos dos Ministros relatores Celso de Mello e Cármen Lúcia, além dos Ministros Cezar Peluso, Menezes Direito, Gilmar Mendes, Carlos Ayres, Marco Aurélio e Ellen Gracie. A não concessão da segurança nos MS 26.602 e 26.603 decorreu do fato de os deputados migrantes litisconsortes passivos não terem sido atingidos pela data apontada como marco para validade do novo entendimento. Isto é, estes parlamentares efetivaram suas trocas anteriormente ao pronunciamento do TSE em 27.03.07, portanto, não estariam sujeitos à perda de seus mandatos. O deferimento parcial do último mandado de segurança, como será oportunamente visto, decorre da suposta mudança posterior à referida data, efetivada pela parlamentar Jusmari Oliveira. STF, Pleno, MS 26.602-DF, rel. Min. Eros Grau, 04.10.07, DJE 17.10.08. STF, Pleno, MS 26.603-DF, rel. Min. Celso de Mello, 04.10.07, DJE 19.12.08.
} 
qual se elegeu. Foram designados relatores, respectivamente, os Ministros Eros Grau, Celso de Mello e Cármen Lúcia.

A decisão ora proclamada se estenderia somente a Deputados Federais, Estaduais, Distritais e Vereadores, tendo sido determinada a data de 27 de março de 2007 (data da resposta do TSE à Consulta N. 1.398), como ponto de inflexão para análise dos casos concretos de desfiliação partidária ensejadora de perda do mandato eletivo, ou, em outros termos, o início da vigência do instituto da fidelidade partidária no ordenamento pátrio $^{496}$. Livraram-se, deste modo, vinte e três Deputados cujos mandatos eram objeto de requisição pelos partidos impetrantes - pois efetivaram suas trocas partidárias anteriormente à data mencionada - restando a devolutiva ao TSE para julgamento apenas do caso da parlamentar Jusmari Oliveira, egressa do DEM em data posterior ao limite, passível, portanto, de sanção com perda do mandato.

Selecionou-se, para compreensão do posicionamento da corrente majoritária que se formou no Supremo - conforme anteriormente explanado - o voto do Ministro relator Celso de Mello, nos autos do MS 26.603. Sua lógica e linha de argumentação foram seguidas pela maioria dos Ministros, inclusive nas outras duas ações julgadas conjuntamente. No grupo dos votos favoráveis à manutenção do mandato pelo partido, será igualmente importante a análise dos votos dos ilustres Ministros Gilmar Mendes e Carlos Ayres Britto que trouxeram elementos diferenciados para enriquecer o debate.

O Ministro Celso de Mello recordou que fora vencido no MS 20.927 em 1989, quando então havia desenhado a tese acolhida posteriormente pela Alta Corte eleitoral na resposta à Consulta N. 1.398, quase duas décadas após.

Inicialmente o Ministro relator cuidou de combater as preliminares suscitadas pelos litisconsortes passivos, a saber: a) a existência de direito líquido e certo; b) a extrapolação de competência do TSE ao adentrar na análise de matéria constitucional quando da resposta à Consulta N. 1.398; c) o caráter interna corporis da matéria; d) a legitimação passiva "ad causam” do Presidente da Câmara dos Deputados para figurar na ação.

\footnotetext{
${ }^{496}$ Dentre os votos majoritários, formaram-se três posições distintas quanto ao marco de entrada em vigor do instituto: a primeira que defendia a retroação ao início da legislatura; a segunda, ex nunc - a partir da decisão do STF, que se deu em 04/10/2007; e, por fim, a vencedora, marcando o início da contagem após o pronunciamento do TSE à Consulta N. 1.398. A chamada "calibragem dos efeitos da decisão" (Min. Gilmar Mendes), foi decidida pelo voto médio, contando com apoio de seis Ministros: Celso de Mello, Cármen Lúcia, Gilmar Mendes, Cezar Peluso, Menezes Direito e Ellen Gracie. STF, Pleno, MS 26.603-DF, rel. Min. Celso de Mello, 04.10.07, DJE 19.12.08.
} 
Em referência à invasão do campo da autonomia partidária, de pronto descartou a hipótese, deduzindo estar a questão vinculada à matéria constitucional, extrapolando os limites dos assuntos internos às agremiações, sendo, portanto, típicos da jurisdição da Corte Suprema, afastando suposta interferência do Judiciário em assunto interno e peculiar dos partidos políticos sujeitos à reserva estatutária ${ }^{497}$. Adicionou a esse argumento o direito de livre acesso ao Judiciário ou garantia de tutela jurisdicional do Estado, como pilar régio do Estado Democrático de Direito.

Sustentou, também, a legitimidade da atuação da Corte Eleitoral, pois alegou ser o instituto da Consulta instrumento autorizado pelo art. 23 do Código Eleitoral, para resposta, em tese, da indagação tal como fora proposta, mesmo versando esta sobre matéria constitucional ${ }^{498}$. Tal função prudencial visa clarificar dúvidas e evitar litígios, sem eficácia vinculante, mantida a autonomia dos órgãos jurisdicionais no exame de cada caso em concreto. Tem o instituto caráter meramente administrativo e não jurisdicional, não decorrendo da manifestação do TSE em sede de Consulta a criação, modificação ou extinção de direitos, pois nesta não se produz Direito, certo estar desprovida de conteúdo normativo $^{499}$.

No demais, decidido o afastamento de todas preliminares, passou-se ao deslinde da questão. Assim, ao introduzir a análise do mérito o Ministro Celso de Mello assumiu, de pronto, seu posicionamento em prol da fidelidade e passou ao exame das seguintes questões de alcance constitucional:

\section{A) O monopólio dos partidos políticos}

Quanto à relevância do papel dos partidos, o Ministro Celso de Mello discorreu longamente sobre o histórico destes para provar a alta significância e

\footnotetext{
${ }^{497} \mathrm{O}$ art. 17, $\S 1^{\circ}$., da Constituição Federal da República do Brasil de 05.10.88, prevê que a fidelidade partidária é assunto a ser assentado no estatuto dos partidos políticos, extraindo-se daí o caráter interno, privado e volitivo do instituto.

498 O Ministro relator fundamentou sua assertiva na linha da jurisprudência do STF pela qual os órgãos do Judiciário exercem o controle incidental da constitucionalidade, inclusive em sede de Consulta, quando do exame em tese efetivado pelo TSE. STF, Pleno, MS 26.603-DF, rel. Min. Celso de Mello, 04.10.07, DJE 19.12.08.

${ }^{499} \mathrm{O}$ entendimento é pacífico na doutrina, segundo o Ministro e presente nas decisões: STF, MS 1.263AgR/MS, rel. Min. Célio Borja e STF, RMS 21.185/DF, rel. Min. Moreira Alves. STF, Pleno, MS 26.603DF, rel. Min. Celso de Mello, 04.10.07, DJE 19.12.08. Acrescentou o Ministro Celso de Mello ser este o motivo da insuscetibilidade de ADI a fiscalizar a constitucionalidade de Consulta emanada pelo TSE. V. STF, ADI-MC N. 2.346/RJ, rel. Min. Celso de Mello, 15.12.00, DJ 01.02.01. Todavia, como será oportunamente examinado, a questão viria a ser objeto das ADI N. 3.999 e 4.086.
} 
indispensabilidade em nosso sistema político e o relevo constitucional que estes adquiriram, especialmente após a Segunda Grande Guerra ${ }^{500}$. Aos partidos cedeu-se o monopólio das candidaturas, colocando-os como corpos intermediários a viabilizar o acesso dos cidadãos ao exercício do poder político, tornando-os verdadeiros canais de expressão das vontades políticas da sociedade civil $^{501}$. A essencialidade dos partidos se extrai da tarefa fundamental que exercem no processo de legitimação do poder estatal e gestão política, por serem o meio imprescindível para o desempenho das funções políticas estatais.

A primazia dos partidos na democracia hodierna foi ressaltada pelo Ministro relator ao frisar a impossibilidade de o Estado atentar contra a autonomia partidária, o que repele "qualquer possibilidade de controle ideológico do Estado sobre os partidos políticos", garantindo-lhes a liberdade de opinião e a liberdade de associação, ambas essenciais ao princípio democrático e das quais decorre o direito fundamental da oposição democrática $^{502}$. Ainda assim, lembrou o Ministro Celso de Mello não serem os partidos imunes às normas inscritas na Constituição e ressaltou efusivamente o papel de "veículo necessário" do partido na democracia representativa.

Por sua vez, o Ministro Gilmar Mendes - para quem os partidos são associações privadas com funções constitucionais - destacou que a importância destes transcende o momento das eleições, pois o processo de formação da vontade política se projeta para além do período eleitoral, fazendo dos partidos instituições de participação política permanentes. Citando SCOTT MAINWARING ${ }^{503}$, constatou deterem os partidos um "monopólio absoluto das candidaturas". Ademais, alçou o partido político à condição de direito e garantia fundamental. Em seu douto entendimento, o constituinte, ao incorporar a regulamentação dessa instituição no Título II da Carta de 1988, estabeleceu que o exercício da cidadania política se processasse também pelos partidos políticos, que são igualmente

${ }^{500}$ No Brasil, a Constituição de 1946 marca o status conferido aos partidos políticos. Cf. voto do Ministro Celso de Mello. STF, Pleno, MS 26.603-DF, rel. Min. Celso de Mello, 04.10.07, DJE 19.12.08.

${ }^{501}$ De acordo com a Constituição alemã de 1949, "os partidos concorrem para a formação da vontade política do povo". É o disposto no art. 21 da referida Carta.

502 Termos empregados pelo Ministro Gilmar Mendes, para quem o direito de oposição é uma garantia institucional da representação política e da própria democracia. A troca constante de cadeiras prejudica, no seu douto pensamento, essa oposição democrática. Mencionou ainda o Ministro a notória "corrida" para a base governista observada nas últimas legislaturas decorrente da atração exercida pelo Poder Executivo e possível graças à livre migração, que afeta a representatividade dos partidos de oposição. Para o Min. Celso de Mello, a importância dessa constatação reside justamente na viabilização das minorias no parlamento, elemento indispensável dos regimes democráticos. Trata-se do equilíbrio buscado pela equação majority rules + minority rights. STF, Pleno, MS 26.603-DF, rel. Min. Celso de Mello, 04.10.07, DJE 19.12.08.

${ }^{503}$ S. MaINwaring, Políticos, Partidos e Sistemas Eleitorais, in Estudos Eleitorais, TSE, n. 2, mai/ago 1997, p. 335, APUD Min. Gilmar Mendes in STF, Pleno, MS 26.603-DF, rel. Min. Celso de Mello, 04.10.07, DJE 19.12.08. 
titulares dos direitos políticos, ao lado dos eleitores e dos candidatos. Tais direitos, ainda que não expressos no texto constitucional, decorrem do sistema político-partidário estabelecido no ordenamento pátrio, ensinou o Ministro Gilmar Mendes.

O Ministro Celso de Mello recorrera ao monopólio partidário e à prévia filiação como pressuposto de elegibilidade, para desenhar sua linha argumentativa, nos mesmos moldes vistos quando da análise dos votos dos Ministros do TSE, em especial ao do Ministro Asfor Rocha, a quem fez remissão. O Ministro Celso de Mello concluiu, da mesma forma que o magistrado do TSE, que os votos pertencem ao partido e com isso também o mandato lhes é atribuído, reeditando a construção do raciocínio segundo o qual a importância do partido na democracia atual e sua imprescindibilidade, conjugada com o sistema eleitoral proporcional, culminam em uma única conclusão: o mandato é do partido. Nesse sentido, o Ministro Celso de Mello compactuou com Celso RiBEIRo BASTOS ${ }^{504}$, que descreve o regime vigente como uma democracia de sustentação partidária, bem como deu razão o ex-Ministro e advogado dos partidos PSDB e DEM, Paulo Brossard, cuja posição pró-fidelidade já se fazia presente nas decisões precedentes analisadas neste capítulo. Em sua sustentação oral, o então patrono dos impetrantes destacou a condição de elegibilidade, a necessidade do partido para o candidato se eleger e a detenção do mandato pelo partido, como elementos a justificar o monopólio político-partidário.

\section{B) O valor da fidelidade partidária para o sistema proporcional}

Quanto ao caráter partidário do sistema proporcional, relembrou o Ministro Gilmar Mendes a vigência desse sistema desde 1932, incorporado na Constituição de 1934 e que se tornou puramente proporcional em 1935, com escrutínio em listas abertas e votação uninominal, diferenciando-se do modelo tradicional. Explanou, com isso, a fórmula do cálculo do número de vagas a serem atribuídas pelos partidos, a partir dos quocientes eleitoral e partidário, sendo o primeiro a proporção entre os votos válidos e o número de vagas e o segundo a divisão do número de votos obtidos pelos partidos e seus candidatos pelo quociente eleitoral. Desta lógica advinda da engenharia eleitoral, o Ministro Celso de Mello extraiu a conclusão de que os eleitos o são com votos do partido político, repetindo o entendimento do TSE. Em acréscimo, o Ministro Gilmar Mendes grifou que o sistema eleitoral proporcional permite a eleição de candidato sem nenhum

${ }^{504}$ C. R. BAStos, Comentários à Constituição do Brasil, vol. 2, Saraiva, São Paulo, 1989, p. 584-604. 
voto nominal, fato ocorrido nas eleições de 1945. O inverso também é possível: o candidato mais votado não obter a vaga caso seu partido não alcance o quociente eleitoral, ocorrência presenciada por algumas vezes, conforme constatou o Ministro. Tudo isso foi relatado para demonstrar que, no contexto da democracia pelos partidos, o valor da fidelidade partidária adquire maior densidade, pois comprovada a imprescindibilidade do partido para o candidato obter sua vaga no sistema eleitoral proporcional. O Ministro Gilmar Mendes observou, ainda, que a Constituição vigente adotou o sistema representativo bicameral, sendo a Câmara dos Deputados a casa que abriga representantes do povo e o Senado os representantes dos Estados e Distrito Federal. Donde conclui que na democracia representativa, "tendo em vista o modelo eleitoral proporcional, parece certo que a permanência do parlamentar na legenda pela qual foi eleito torna-se condição imprescindível para a manutenção do próprio mandato"505.

Há, sem dúvida, para o Ministro Gilmar Mendes, um direito líquido e certo dos partidos às cadeiras por eles conquistadas sobre o sistema proporcional. Apoiou sua lógica em MAURICE DuVERGER. Segundo o autor francês, a democracia pelos partidos mudou o caráter da representação política e trouxe ao eleito um "duplo mandato: do partido e dos eleitores", relação onde o "mandato partidário tende a sobrelevar o mandato eleitoral". Além do mais, a corrente majoritária posicionou-se no sentido de que a transmigração viola frontalmente o sistema proporcional ${ }^{506}$, pois este se funda nos partidos.

Se por um lado a lógica do sistema proporcional parece facilmente dar suporte à tese de que o mandato é do partido, essa linha de argumentação necessariamente refutaria a propriedade partidária dos mandatos eletivos obtidos pelo sistema majoritário. Cai-se, de fato, em uma via de mão única, teoricamente sem volta. No sistema majoritário, não havendo de se falar em "monopólio do partido", livre estaria a transmigração. Todavia, ainda nesse sistema, a filiação partidária também é condição necessária para eleger-se. O sofisma, que aparentemente se justifica de um lado, complica-se de outro e obrigaria, mais tarde, a Corte a contornar a situação para que a moralidade também prevalecesse para os cargos eletivos obtidos por votos majoritários.

${ }^{505}$ STF, Pleno, MS 26.603-DF, rel. Min. Celso de Mello, 04.10.07, DJE 19.12.08.

${ }^{506} \mathrm{O}$ Ministro Celso de Mello discorre longamente para afirmar que o sistema proporcional é o "mais adequado ao exercício democrático do poder". STF, Pleno, MS 26.603-DF, rel. Min. Celso de Mello, 04.10.07, DJE 19.12.08. Para um amplo e conclusivo debate, v. L. Virgílio Afonso DA Silva, Sistemas Eleitorais - Tipos, efeitos jurídico-políticos e aplicação ao caso brasileiro, São Paulo, Malheiros, 1999. 


\section{C) O mandato representativo, o "duplo vínculo" e a "dupla fidelidade"}

No debate das relações entre o eleitor, o partido e o representante parlamentar, o Ministro relator Celso de Mello afirmou a existência de um duplo vínculo (o vínculo partidário, entre partido e parlamentar e o vínculo popular, entre cidadão e representante), fruto da evolução do conceito e da natureza do mandato representativo no moderno constitucionalismo. Para o Ministro, apoiando-se em N. BOBBIO, a sequência hoje prevalente se processa na seguinte ordem: eleitores - partidos - representantes individuais, sendo esta a relação primária e mais importante, na qual o eleitor acessa o partido, assim como o papel do representante está ligado diretamente ao dos partidos. Disso inferiu o Ministro relator que o mandato eletivo decorre tanto da representação popular quanto de uma representação partidária, configurando um novo sentido do mandato representativo. Para o Ministro Carlos Britto, a Constituição autoriza-lhe a falar em representante do partido, pois exsurge do Texto Magno tal disposição, encontrada na leitura que fez dos parágrafos $2^{\circ}$. e $3^{\circ}$. do art. 55 , bem como do inciso VIII do art. $103^{507}$.

Se, de um lado, o Ministro Celso de Mello nada mencionou sobre o caráter livre do mandato representativo, no qual o representante se desvincula do seu eleitor e abstém-se de sofrer qualquer controle na sua liberdade de expressão e pensamento, de outro, propugnou "a formação de um novo modelo de representação" denominado "mandato representativo partidário", como evolução dos mandatos imperativos do Velho Regime e representativos do Estado Liberal.

Por sua vez, o Ministro Gilmar Mendes fez questão de ressaltar que o entendimento por ele professado não leva a uma concepção de mandato imperativo ou vinculado. Da irrevogabilidade do mandato, tanto pelos eleitores, quanto pelo partido, extrai-se a noção de que o mandato representativo continua sendo livre, não se vinculando o representante aos representados, afirma o Ministro. O caráter livre do mandato continua sendo preservado sob essa nova ótica jurisprudencial, pois compatível com a detenção dos mandatos pelos partidos, na prudência do Ministro Gilmar Mendes.

Aprofundando-se no dilema da alteração da natureza da representação política devido à duplicidade do mandato, sugeriu o Ministro Celso de Mello que o exame de toda a questão fosse feito sob dupla ótica: fidelidade ao partido e fidelidade aos

\footnotetext{
${ }^{507}$ Como será repetidamente comentado nesse estudo, a representação do parlamentar vis a vis ao partido não compõe o conceito de representação política pelo qual o titular do poder soberano - o povo - o transmite ao representante eleito.
} 
cidadãos, consequência do duplo vínculo, que, na transgressão, é duplamente fraudado, segundo o Ministro. Frustra as expectativas do eleitor que escolheu uma ideologia partidária e renega o auxílio obtido do partido para alcançar sua eleição. Retoma-se, assim, a "teoria da traição", sob o rótulo de desrespeito à vontade soberana do povo. Ressurgem as questões: como se aufere a vontade do povo, senão pelas eleições ou pelos modos de participação direta? Qual o órgão legitimado para recolher a vontade geral? É possível à Corte Maior inferir a vontade do povo?

\section{D) A interpretação principiológica e alteração jurisprudencial}

O Ministro Carlos Ayres Britto, em antecipação ao seu voto, proclamou que os princípios são normas, fazendo expressa alusão ao modelo de ciência jurídica "que é o pós-positivismo", que, além de propor o caráter normativo dos princípios, atesta, segundo palavras do próprio Ministro, "que eles são supernormas, as normas mais importantes do direito positivo, notadamente da Constituição, (...)".

Em sintonia com os pensadores pós-postivistas, o Ministro Celso de Mello proferiu que "o direito vindicado pelos partidos (...) não nasce nem surge da resposta que o TSE deu (...), mas representa emanação direta do próprio texto da Constituição (...)". Porém, como o Ministro Eros Grau viria a demandar por três vezes: "apontem-me onde!". Respondeu-lhe o Ministro Celso de Mello, pretendendo que a solução estaria contida nos "fundamentos e nos princípios estruturantes em que se apóia o Estado Democrático de Direito, como a soberania popular, a cidadania e o pluralismo político." Retomou, ademais, a tese do Ministro Peluso, suportada igualmente pelo Ministro Gilmar Mendes, segundo a qual não se trataria de sanção, mas de reconhecimento do direito subjetivo do partido às vagas conquistadas, lógica derivada do sistema proporcional, da qual o magistrado da Corte Eleitoral extrairia a irrelevância de não constar no ordenamento norma expressa a respeito.

Com base na liberdade de associação constitucionalmente prevista no art. $5^{\circ}$. da Carta Magna, o Ministro Carlos Britto trilhou a mesma lógica do Ministro relator, afirmando não se configurar a desfiliação um ato ilícito, ainda que imoral. Não obstante, considerou o Ministro ser o ato "uma opção que tem suas consequências jurídicas." O desligamento voluntário "não pode deixar de implicar uma perda do mandato. Perda, não como castigo ou sanção (...), porém como renúncia tácita” é o que expressou o Ministro de 
ambas as Cortes, fazendo comparação à situação do sócio retirante de qualquer entidade de espécie associativa.

Realmente, não se pode negar que a constante troca de legendas atinge a essência do sistema eleitoral, quanto à proporcionalidade da representação partidária no Congresso. Inferir-se a partir daí, que o parlamentar não perde o mandato, porque não o possui e que apenas renuncia a ele tacitamente, parece soar mera retórica, tanto quanto pretender não haver caráter sancionatório. Ao definir-se que a desfiliação implica a cessação da atividade parlamentar de parte do representante eleito, pouco importa a que título esse desligamento se processou: se a título de perda ou de renúncia, se por sanção ou ausência de direito subjetivo. Fato é que a consequência será a mesma e uma só: não será mais o Deputado migrante representante do povo, não mais exercerá função parlamentar senão eleito novamente na próxima legislatura. Em suma, ainda que não se chame de sanção, seus efeitos são os mesmos, como se punição fosse. Do ponto de vista do parlamentar, inegável a ocorrência de uma perda subjetiva. De outra forma, inadmitindo-se que o suplente do partido possa preencher a vaga do trânsfuga, a perda se dará, no enfoque do partido, para este, que terá sua representatividade no parlamento reduzida. Percebe-se que se está diante de uma questão de alta indagação. A ideia propagada de renúncia tácita do mandato outorgado ao parlamentar pouco haveria de prosperar, mas antes estaria a gravar a Resolução do TSE com severa inconstitucionalidade, à medida que claramente se buscava uma forma de contornar o rol taxativo do art. $55 \mathrm{CF} / 88$, mesmo diante da ausência de qualquer manifestação volitiva por parte do parlamentar - o que, obviamente, invalida qualquer tese de renúncia tácita.

Quanto à observação de que a infidelidade é uma fraude à vontade do eleitor, foram feitas anteriormente algumas considerações quando da análise da Consulta ao TSE. Dizer que a migração é um ultraje à vontade do cidadão é tapar os olhos para a real situação de um eleitorado que elegeu para atual legislatura no Congresso Nacional, Clodovil e Frank Aguiar, entre outros, como já fez com Agnaldo Timóteo e outras celebridades do meio artístico musical ${ }^{508}$, sem sequer saber qual era o seu partido ou sua ideologia partidária. É mais arriscado dizer que esse eleitorado gostaria que esses candidatos perdessem seu mandato por ocasião da troca de legendas do que o contrário.

${ }^{508}$ Notadamente se faz sentir a forte influência da mídia na formação e informação política do povo, colocando em destaque personalidades dos diversos meios, que, expostas principalmente no meio televisivo, adquirem espaço na "memória política" dos eleitores, mormente em nações menos desenvolvidas e nas fatias da população com menor acesso à cultura e à educação. Para um amplo debate, v. a obra de M. G. FERREIRA FILHO, A Democracia no século XXI, cit., que trata da questão da influência tanto da mídia quanto da educação - as condicionantes culturais da democracia. 
Novamente se sobressaem as fragilidades da "teoria da traição", que não deveria ser empregada para demonstrar o desvio ético-político apontado, tampouco para justificar a perda de mandato por troca de partido.

Reforçando a percepção inicial de mudança de direcionamento da Corte Suprema, encontra-se no voto do Ministro Celso de Mello a transcrição da posição do Ministro Gilmar Mendes, quando do julgamento da cláusula de barreira (ADI N. 1.351), no qual já se propunha mudança do posicionamento do Supremo em relação à fidelidade partidária. O próprio Ministro Gilmar Mendes relembrou em seu voto, nos mandados em exame, sua assertiva propagada na mencionada Ação Direita de Inconstitucionalidade, pela qual haveria, desde a época, uma "necessidade imperiosa de revisão da jurisprudência do STF" 509 quanto à questão da troca partidária. Considerou estar-se diante de caso "típico de mutação constitucional, em que se altera a jurisprudência longamente adotada pela Corte". Para esses casos de revisão jurisprudencial, visando preservar a segurança jurídica, tem sido precedente do Supremo a modulação dos efeitos da decisão, que devem ser precisamente delimitados, em face da mudança interpretativa sem alteração formal no texto da Lei. Citou ainda três exemplos nos quais o Tribunal fixou novo entendimento em sentido diverso ao que vinha mantendo, para os quais foi crucial a preservação dos atos juridicamente perfeitos praticados sob a égide do entendimento superado ${ }^{510}$. Quanto à liberdade interpretativa da Corte guardiã da Constituição, o Ministro Mendes apontou que o aspecto temporal pode tornar necessário um novo entendimento dos tribunais, permitindo ao Tribunal abandonar a interpretação anterior se os Ministros se convencerem que esta não mais gera conclusões suficientemente seguras. Ou seja, a validade e a correção de uma linha interpretativa muda com o tempo e pode ser alterada. Porém, deve-se escolher a interpretação que seja atual e conforme com a Constituição. Baseando-se em PETER HÄBERLE, que propõe uma interpretação constitucional aberta e uma reforma constitucional flexível, o Ministro Gilmar Mendes coloca a interpretação de uma norma como um ato de integração deste à realidade pública e colocação no tempo atual ${ }^{511}$.

\footnotetext{
${ }^{509}$ Em posterior julgamento, na ADI 3999, o Ministro Gilmar Mendes recuperou a justificativa para mudança de rumos da Corte Suprema, atentando para um momento de crise política, marcado por um forte "fenômeno da cooptação sem quartel que se fazia no âmbito federal, estadual e municipal" e que "afetava o próprio processo democrático" ao transformar oposição em situação pela simples mudança de legenda pelo parlamentar.

${ }^{510}$ Foram exemplos mencionados pelo Ministro os seguintes julgamentos: Questão de Ordem no INQ 687, DJ 09/11/01, do CC N. 7204/MG, 29.06.05; HC N. 82.959 e RE N. 353.657/PR e N. 370.682/SC.

511 P. HÄBERLE, Zeit und Verfassung, in Probleme der Verfassungsinterpretation, org. Dreier, Ralf/Schwegmann, Friedrich, Nomos, Baden-Baden, 1976, p 312-3, APUD Min. Gilmar Mendes in STF, Pleno, MS 26.603-DF, rel. Min. Celso de Mello, 04.10.07, DJE 19.12.08.
} 
Nesse sentido, o Ministro destacou que a Corte não poderá "fingir que sempre pensara desta forma", fato que se pode até inferir de alguns pronunciamentos dos ilustres Ministros nos referidos julgamentos ${ }^{512}$. Enfim, quis mostrar o Ministro que o tempo opera e operou mudanças e a evolução da valoração deve ser admitida ${ }^{513}$, porém, ajustada, pois é certo que a nova orientação reclama cuidados especiais. Tal alerta se referia especificamente ao marco estabelecido para que os efeitos proclamados fossem ser produzidos. Satisfatória, na visão do Ministro, para efeitos de modulação e garantia da segurança jurídica, a data da decisão do TSE, como marco da mudança.

\title{
E) A preservação do direito de defesa
}

A observância ao direito de ampla defesa fora suscitada pelos litisconsortes passivos, bem como pelos Ministros Eros Grau e Ricardo Enrique Lewandowski. Em que pese o reconhecimento de que se está diante de uma garantia constitucional, prolatou o Ministro Celso de Mello que

\begin{abstract}
"torna-se necessário assegurar, ao Deputado, naqueles casos em que se justificar o ato de sua voluntária desvinculação (...) exercendo (...) a prerrogativa de fazer instaurar, perante órgão competente da Justiça Eleitoral (o TSE, tratando-se de Deputado Federal), procedimento em cujo âmbito se lhe viabilize a possibilidade de demonstrar a ocorrência das exceções justificadoras da desfiliação partidária." 514 (grifos no original).
\end{abstract}

Ora, com bem demonstrou estar ciente o Ministro relator ${ }^{515}$, é de se convir que o princípio da ampla defesa e do contraditório existem exatamente porque nem sempre é possível se certificar, a priori, quais são os casos em que a defesa é

\footnotetext{
${ }^{512}$ É o caso do entendimento dos Ministros Celso de Mello e Carlos Britto, que pretendem extrair de uma "interpretação sistêmica" ou diretamente do texto positivado, a consequência de perda do mandato quando da desfiliação do parlamentar. STF, Pleno, MS 26.603-DF, rel. Min. Celso de Mello, 04.10.07, DJE 19.12.08.

${ }^{513}$ Ao justificar por meio do direito comparado a evolução jurisprudencial, o Ministro Gilmar Mendes relata um razoável número de decisões da Corte norte-americana, pontuando em cada caso a rápida mudança do entendimento jurisprudencial. Com vênia ao esforço do Ministro, talvez a comparação com um sistema tão flexível e aberto não fosse o melhor espelho para um ordenamento regido por uma Constituição rígida ou semi-rígida. STF, Pleno, MS 26.603-DF, rel. Min. Celso de Mello, 04.10.07, DJE 19.12.08.

${ }^{514}$ STF, Pleno, MS 26.603-DF, rel. Min. Celso de Mello, 04.10.07, DJE 19.12.08.

${ }^{515}$ Celso de Mello reconhece a premência do contraditório e da ampla defesa ao afirmar em seu voto que "a legitimidade ético-jurídica de qualquer medida imposta pelo Poder Público", que grave direitos, requer a "fiel observância do princípio do devido processo legal", sejam estas medidas restritivas revestidas ou não de caráter punitivo. STF, Pleno, MS 26.603-DF, rel. Min. Celso de Mello, 04.10.07, DJE 19.12.08.
} 
justificável ${ }^{516}$. A garantia do devido processo legal foi constitucionalmente instituída, pois a defesa se presume justificável e necessária em todos os casos. Por esses mesmos motivos, cerceada estaria a defesa se, em sede de mandado de segurança, fosse determinada a perda do mandato dos litisconsortes pelos Ministros do Supremo. Nem há de se cogitar que a remessa à Justiça Eleitoral para instauração do contraditório se processe apenas quando alegada a perseguição do partido ou mudança ideológica deste, pois do contrário seria praxe protelatória a contestação pelos parlamentares trânsfugas nesse sentido. De qualquer forma, o procedimento de jurisdição voluntária, seja em caso de iniciativa do parlamentar ou do partido, requer a produção de provas a justificar a transmigração. Para solucionar tal problema, o Ministro Celso de Mello sugeriu, à época, que o TSE editasse Resolução com a finalidade de regulamentar o procedimento administrativo de justificação, o que viria a se concretizar poucos dias depois de firmada a decisão do STF, na edição da Resolução N. 22.610/07 do TSE.

\section{F) A legitimidade do STF para julgar a questão}

Em resposta aos litisconsortes passivos, o Ministro Carlos Britto, nas considerações preliminares ao seu voto, procurou demonstrar a legitimidade da Suprema Corte para decidir a questão. Consignou que a nação ${ }^{517}$ é a detentora do poder constituinte originário, produzindo o Direito por meio de um processo eletivo. Disso decorre que "a primeira legitimidade democrática é a expressa pela Assembleia Constituinte" e "tudo o mais já é uma legitimidade pós-Constituição", pretendendo com tal assertiva mostrar que o constituinte, pela redação da Carta Maior, institui as demais legitimidades, dentre as quais a legitimidade popular dos parlamentares e das chefias executivas, advindas do processo eleitoral periodicamente renovável. De igual forma - seguiu o Ministro Britto - a legitimidade do Judiciário e do STF defluem da Constituição. A legitimidade da guarda da Constituição pela Suprema Corte, não é eletiva, mas é uma vontade normativa da nação,

\footnotetext{
516 A necessidade de dilação probatória, aliás, foi motivadora do entendimento do Procurador-Geral da República em reconhecer a ausência de direito líquido e certo a viabilizar o mandamus, conforme pontuado neste capítulo.

${ }^{517}$ O Min. Carlos Ayres Britto comentou sobre a diferenciação dos conceitos de povo e nação. A nação, nas palavras do Ministro, se configura em "uma realidade atemporal, pois é mais que o povo. Este é uma realidade do aqui e do agora (...). A Nação é uma linha imaginária que costura a unidade do povo de ontem, do povo de hoje e do de amanhã". STF, Pleno, MS 26.603-DF, rel. Min. Celso de Mello, 04.10.07, DJE 19.12.08. Para distinção dos conceitos de povo e nação, Cf. D. A. DAllaRI, Elementos de Teoria Geral do Estado, 25a . ed., São Paulo, Saraiva, 2005, p. 95-134.
} 
depositada no Texto Magno. "São duas democracias, duas legitimidades", chegou a afirmar o Ministro. Da função constitucionalmente positivada da guarda maior, disse o Ministro, infere-se a legitimidade da Corte. Indo mais além, concluiu que "interpretar e aplicar a Constituição, inclusive na perspectiva da demarcação dos espaços de legítima atuação dos Poderes, não é usurpação, é isso que nos cabe fazer”, no exercício de uma função política, com fundamentação técnico-jurídica.

Em semelhante sentido, negou veementemente o Ministro Celso de Mello que "estaria usurpando atribuições do Congresso Nacional”, pois,

"cabe ao Supremo Tribunal Federal, em sua condição institucional de guardião da Constituição, interpretá-la e, de seu texto, extrair, (...) a máxima eficácia possível, em atenção e respeito aos grandes princípios estruturantes que informam, (...) o sistema de nossa Lei Fundamental." 518

Tal afirmação reflete o atual entendimento da Suprema Corte quanto à força normativa da Carta Maior, bem como em referência aos limites da interpretação e justifica a ampla aplicação de princípios, segundo o Ministro.

Abre-se, desta forma, todavia, uma perigosa brecha, mormente quando se interpreta contra legem. A situação se agrava quando o Ministro Celso de Mello considera que: "o poder de interpretar a Constituição envolve, em muitos casos, o poder de formulála. (...) Nos Tribunais incumbidos da guarda da Constituição, funciona, igualmente, o poder constituinte" ${ }^{519}$. Dessa função tipicamente política, no magistério do ilustre Ministro relator, extrai-se o monopólio e a força vinculante do pronunciamento último da Corte Suprema sobre as normas constitucionalmente positivadas. E, propôs o Ministro evidenciando uma mudança de posicionamento do Supremo também quanto à sua função interpretativa - uma "substancial revisão de padrões jurisprudenciais, com a consequente ruptura de paradigma dela resultante (...) a partir do qual deverá instaurar-se a eficácia do novo padrão hermenêutico". Em seu entendimento, a revisão substancial da jurisprudência convive plenamente com a segurança jurídica.

${ }^{518}$ STF, Pleno, MS 26.603-DF, rel. Min. Celso de Mello, 04.10.07, DJE 19.12.08.

${ }^{519}$ STF, Pleno, MS 26.603-DF, rel. Min. Celso de Mello, 04.10.07, DJE 19.12.08 


\subsubsection{Posições divergentes no STF}

Visando trazer os principais fundamentos que apontaram ideias divergentes, adotou-se o voto do relator do mandado de segurança 26.602, Ministro Eros Grau, como símbolo da dissidência dos membros do Supremo, sem com isso deixar de trazer elementos destacados pelos Ministros Joaquim Barbosa e Ricardo Enrique Lewandowski, ambos também contrários ao posicionamento majoritário que se formou neste julgamento.

O PPS impetrou o mencionado mandamus contra a autoridade do presidente da Câmara dos Deputados que havia se negado a declarar a vacância dos mandatos de oito Deputados que migraram para outros partidos. O Ministro relator combateria veementemente a posição majoritária e renovadora que se formava na Corte Suprema, como transparecerá na análise dos principais tópicos a seguir.

\subsubsection{A ausência de direito líquido e certo}

O Ministro Eros Grau iniciou seu voto de preliminar de mérito, observando que o deslinde da questão requereria a possibilidade do exercício de ampla defesa dos litisconsortes, com ampla produção de provas ${ }^{520}$. Pairando dúvidas sobre os motivos que causaram a mudança de legenda dos oito litisconsortes passivos, não haveria de se falar em direito provado de plano. Em outras palavras, admitindo-se tal hipótese, configurar-se-ia a inadmissibilidade do writ, diante da falta de direito líquido e certo dos impetrantes. Ademais, prosseguiu o Ministro, em todas as previsões constitucionais da perda do mandato, é naturalmente prevista a ampla defesa. O Ministro Lewandowski demonstrou entendimento parelho, alegando que a matéria não poderia ser debatida via mandado de segurança, vez que premente a dilação probatória, incompatível com o tipo de ação proposta - segundo o melhor posicionamento da Corte Suprema - culminando com a impossibilidade de declaração da perda automática dos mandatos dos litisconsortes. Ainda em análise de preliminares, destacou o Ministro Eros Grau não ser prerrogativa do presidente da Câmara dos Deputados a declaração de perda de mandato, cabendo, ao revés,

\footnotetext{
${ }^{520}$ Ampla defesa e direito ao contraditório constituem o núcleo do devido processo legal, escrito no art. $5^{\circ}$., LIV, Constituição Federal da República do Brasil de 05.10.88, postulado sobre o qual se assenta o Estado Democrático de Direito.
} 
à Mesa ou ao Plenário desta, que deveria se manifestar previamente, magistério oposto ao professado pelo Ministro Celso de Mello. O Ministro Joaquim Barbosa, por sua vez, empregou o mesmo argumento já na fase de exame do mérito, para concluir pela ausência de liquidez e certeza, pois inviável decretar-se a perda do mandato com base nos elementos trazidos aos autos, diante da impossibilidade de se averiguarem as causas das desfiliações apontadas. Como visto no item anterior, o Ministro Celso de Mello, cuja posição foi acompanhada pela maioria, buscou contornar a problemática da ampla defesa sugerindo remessa à Justiça Eleitoral para exame de tais causas, o que de fato só viria a ser proposta para o único caso de transmigração, dentre os demandados, efetivado após o marco determinado pelo STF.

\subsubsection{A ausência de previsão para a perda do mandato por infidelidade partidária}

O principal argumento do Ministro relator Eros Grau, para refutar o pedido dos impetrantes, seguiu a linha do já analisado voto do Ministro Marcelo Ribeiro do TSE por ocasião da resposta à Consulta N. 1.398, qual seja, o de não se encontrar preceito constitucional permissivo de decretação da perda do mandato por infidelidade. Qualquer reforma política, na visão do Ministro relator Eros Grau, caberia ao Poder Constituinte derivado. Ademais, o que lhe parece politicamente conveniente não deverá pesar para a decisão, diante dos limites do texto da Constituição. Sua posição é diametralmente oposta à do Ministro Celso de Mello, que adotou entendimento favorável à possibilidade de formulação através da atividade interpretativa da Corte Maior.

Quanto ao intenso debate travado no TSE, referente ao nexo causal estabelecido entre a condição de elegibilidade e a perda do mandato, posicionou-se o Ministro Eros firmemente, atentando que "a vinculação a um partido político é somente condição de elegibilidade (...) nada mais." (grifos nossos). Expressamente pontuou que esta "não é condição para que o Deputado permaneça no exercício do seu mandato". E, com grande ênfase, referindo-se à Constituição Federal, desafiou: "apontem-me onde está nela afirmado o contrário".

Calcado em fortes razões, concluiu o Ministro Grau que "a assertiva de que o cancelamento de filiação partidária, com a transferência para outro partido, equivaleria à perda do mandato, resulta de interpretação adversa ao que estabelece a 
Constituição". Tampouco admitiu o Ministro falar-se em renúncia do parlamentar quando da transferência para outra legenda, exceto se tal fato estivesse previsto no estatuto do partido e consubstanciado por ato voluntário expressamente declarado, uma vez que "toda e qualquer renúncia de ordem política reclama e exige sempre um ato formal (...)". Inviável, portanto, admitir-se a ocorrência de renúncia tácita no caso em tela, muito menos a existência de previsão no ordenamento de que a migração partidária a consubstancie. Ao repassar o texto do art. 55 da $\mathrm{CF} / 88$, o Ministro considerou ser taxativo o rol de hipóteses de perda do mandato, colocando que apenas a reforma da Constituição levará ao retorno da institucionalização da fidelidade partidária no ordenamento pátrio. Nem mesmo mutação constitucional seria possível, declarou, pois inexiste, no caso em tela, incongruência entre as normas e a realidade constitucional, entre a Constituição formal e a material. De fato, não se caracterizaria a mutação constitucional, que se opera afastando-se parte do texto da Constituição formal, sem romper com o sistema, conforme visto anteriormente. Desta lógica compartilhou o Ministro Joaquim Barbosa, pontuando a opção deliberada do constituinte em abandonar o regime de fidelidade partidária do sistema constitucional precedente justamente como forma mais democrática em um período de abertura política. Finalizou este tópico, o Ministro relator, acrescentando que nada justifica "que o STF menos ainda o TSE - exorbite de sua função jurisdicional para emendar a Constituição, reformando-a". Não caberia à Corte Suprema pronunciar-se nesse caso (via controle difuso), a menos que houvesse sido proposta uma Ação Declaratória de Constitucionalidade sobre a manifestação do TSE em torno da fidelidade partidária.

De maneira firme, o Ministro Eros Grau criticou a Corte Maior, que, ao invés de guardar a Constituição, estaria a usurpar função exclusiva do Poder Constituinte derivado, caracterizando-se, desse modo, uma "quebra constitucional", ao "ratificar a criação, por via oblíqua, de hipótese de perda de mandato não prevista no texto da Constituição", ferindo os valores fundamentais do Estado de Direito.

\subsubsection{A inovação constitucional por meio de interpretação}

Em adição e em contraposição ao entendimento do presidente do PPS ${ }^{521}$, o Ministro Eros Grau repetiu a lição de K. HeSSE acerca dos limites da interpretação

${ }^{521}$ Roberto Freire, Presidente do PPS, partido impetrante do MS 26.602-DF, pronunciou-se na etapa de sustentação oral durante a sessão plenária do STF no julgamento, como advogado do impetrante, quando 
constitucional, ponto que tem sido enfatizado constantemente no presente estudo e merece ser revistado. Nas palavras do Ministro relator do MS 26.602, "o intérprete já não mais interpreta, porém modifica, opera a ruptura da Constituição quando passa por cima dela. O limite da interpretação é o texto; a Corte está aqui para exigir que esse limite seja observado, não para rompê-lo"522 . Em conclusão, o Ministro Eros Grau pronunciou-se no sentido de que inadmissível seria a inovação proposta no plano constitucional, abrindo perigosa brecha para que, no futuro, o Poder Judiciário pudesse, via interpretação, reescrever a Constituição e quiçá restringir direitos fundamentais. O Ministro, que admite em seus pronunciamentos ${ }^{523}$ ser taxado de positivista e "incendiário" por suas posições divergentes, é contundente na sua posição anti-pós-positivismo e contrário ao ativismo judicial derivado da interpretação expansiva, como se verá em tópico deste capítulo.

\subsubsection{Representantes do povo ou do partido?}

Coube ao Ministro Joaquim Barbosa tecer as principais considerações a respeito da problemática da representação política concernente à matéria em debate. Desafiou a proposição inovadora do Ministro Cezar Peluso, que havia criado a seguinte assertiva: "O Deputado representa o povo, porque escolhido pelo critério partidário" 524 . O Ministro Joaquim Barbosa ressaltou a ausência do nexo de causalidade entre a representação política e a forma pela qual o representante é escolhido. Salta aos olhos a impropriedade de se assumir que a representação do povo é decorrente da forma pela qual a escolha se processa e dos meios ou instrumentos - os partidos - que viabilizam as

afirmou que não se deveria temer uma decisão do STF em prol da fidelidade partidária, pois "não está se legislando em nada". STF, Pleno, MS 26.602-DF, rel. Min. Eros Grau, 04.10.07, DJE 17.10.08.

${ }^{522}$ STF, Pleno, MS 26.602-DF, rel. Min. Eros Grau, 04.10.07, DJE 17.10.08.

${ }^{523}$ Palestra proferida no XVIII Encontro de Direito Constitucional, promovido pela Associação Brasileira de Constitucionalistas - "Instituto Pimenta Bueno", em 26.09.09, na Faculdade de Direito da Universidade de São Paulo.

${ }^{524}$ Relembrando-se, por ocasião da resposta do TSE à Consulta N. 1.398, bem como nos julgamentos dos MS 26.602-DF e ss., o Ministro Cezar Peluso, invertendo a lógica da representação política, parafraseara pronunciamento realizado pelo Ministro Victor Nunes Leal, que considerava que o deputado, embora escolhido pelo critério partidário, representa o povo. Ao atribuir aos partidos, instrumentos de operacionalização das eleições, a causa da representação política, o Ministro Peluso atenta contra a natureza desta, confundindo a essencialidade dos partidos para o processo democrático hodierno, com elemento causal da representação política. Este se transfigura na soberania popular, pois em uma democracia, o poder político é exercido pelo povo. Na impossibilidade de fazê-lo diretamente, faz-se representar. Para se fazer representar, empregam-se os métodos de escolha, que não prescindem dos partidos políticos como organizadores das massas. Em suma, a lógica da representação política não pode ser colocada às avessas: a soberania popular é sua causa; os partidos, instrumentos de sua concretização, à medida que operacionalizam as eleições. E jamais o contrário, como quer o Ministro. STF, Pleno, MS 26.602-DF, rel. Min. Eros Grau, 04.10.07, DJE 17.10.08. 
eleições. Para Joaquim Barbosa, ao colocar o partido político como centro da organização política, fonte da legitimidade democrática, o TSE promove uma inadmissível "partidocracia" e atenta contra a "inteligência que o constituinte quis dar ao nosso sistema de representação política". A Corte teria, no saber do Ministro, se distanciado da realidade, na qual o povo, detentor da soberania, é o elemento chave do Estado Democrático. O poder deriva diretamente do povo, ou em outros termos, o povo é seu titular absoluto e fonte primordial. Fundamenta-se no artigo 45 da Constituição de 1988, que estabelece que a Câmara dos Deputados seja composta de representantes, não dos partidos, mas do povo. Já os partidos políticos, apesar de sua imprescindibilidade, são "meros instrumentos" para o exercício do poder, lembrando-se que estão também constitucionalmente previstas algumas formas de exercício direto do poder pelo povo. Alertou o Ministro que, ainda no contexto da extrema relevância dos partidos na democracia partidária, o povo não renunciou à sua "condição de derradeiro depositário da soberania".

O Ministro Joaquim Barbosa, recuperando as bases da representação política, lembrou que a Constituição define a estrutura dos órgãos estatais cuja função primordial é "traduzir a vontade do povo soberano e não as hipotéticas vontades ou interesses próprios das instituições ou corpos intermediários”. Quis com isso demonstrar que os partidos estão a serviço da nação, para traduzir a vontade do povo, e não o contrário. Advertiu também que, ao alçar os partidos políticos à condição de figura nuclear da representação política, fazendo com que ultrapassem o caráter de meros mecanismos de veiculação da vontade do povo, a corrente majoritária que se formava estaria invertendo a essência da representação política ${ }^{525}$.

O Ministro Lewandowski, em linha similar à do Ministro Joaquim Barbosa, alertou para a fragilidade dos partidos políticos nacionais, atribuída em grande parte à instabilidade democrática (alternância entre regimes ditatoriais e democráticos) presenciada no país no último século, que culminou na dificuldade do desenvolvimento de bases ideológicas consistentes, gerando um quadro de domínio oligárquico dos dirigentes partidários.

O Ministro Joaquim Barbosa chegou a criticar abertamente o tamanho poder atribuído aos partidos políticos por seus colegas. Inicialmente, porque a decisão do TSE alijara o eleitor do processo de manifestação de sua vontade soberana. Além disso, em sua visão, a sociedade de massas hodierna se conecta com diferentes maneiras de expressar

${ }^{525}$ STF, Pleno, MS 26.602-DF, rel. Min. Eros Grau, 04.10.07, DJE 17.10.08. 
sua vontade, citando como exemplo as organizações não-governamentais. Colocou em dúvida a capacidade das agremiações políticas em expressar satisfatoriamente a vontade da sociedade. Raciocínio este referendado pelo Ministro Lewandowski, que atentou para o papel destas organizações em temas específicos como a proteção do meio ambiente e os direitos do consumidor, entre outros, que procuram suprir as deficiências da representação política na prática, além da criação de institutos que aproximam o cidadão do poder como o plebiscito, o referendo e a iniciativa legislativa. Enfim, ambos os Ministros apresentaram uma concepção muito mais próxima da realidade do sistema partidário prevalente nos quadros nacionais, do que uma situação idealizada do dever-ser, apresentada pelos seus colegas de Corte.

Não obstante seus posicionamentos, os Ministros Barbosa e Lewandowski declararam-se concordes com a importância do valor da fidelidade partidária, como um dos elementos para o fortalecimento do sistema partidário brasileiro, sem, porém, elevá-lo à condição de principal causa dos problemas políticos vivenciados. $\mathrm{O}$ Ministro Lewandowski chegou inclusive a alertar que o assunto "não constitui (...) uma panacéia universal", apoiando-se em discurso do ex-Ministro Nelson Jobim, para quem qualquer consideração a respeito da fidelidade partidária, que não leve em conta a "consciência real do que se passa no processo de escolha dos candidatos, é um equívoco", denotando uma maior amplitude dos problemas políticos do país, que não se adstringem à fidelidade partidária.

\subsubsection{O princípio da segurança jurídica}

Interessante destacar da discussão uma problemática demasiadamente importante, que recebeu diversas soluções, conforme o posicionamento pró ou contra a perda do mandato ao parlamentar infiel. O tema da segurança jurídica e o princípio da confiança encontrou eco no debate realizado sobre a questão das garantias constitucionais. De um lado, manifestaram-se no sentido de estarem sendo plenamente atendidas as exigências constitucionais pertinentes, os Ministros Carlos Britto e Celso de Mello. Em oposição, o Procurador-Geral da República enfatizou claramente a questão em seu parecer supra analisado. Seu entendimento foi acompanhado pelo Ministro Lewandowski, que dedicou tópico exclusivo de seu voto ao exame do princípio. Para o Ministro, que tomou como referência os ensinamentos de José JoAquim Gomes CANOTILHO e PAUlo BarRos 
DE CARVAlHO ${ }^{526}$, o valor da segurança se encontra em um grupo privilegiado de princípios, pertencentes ao topo da hierarquia axiológica das constituições, tidos como preceitos de caráter pré-estatal, que "servem de paradigma às demais normas constitucionais", pois são a base do ordenamento e da organização jurídica da sociedade, legitimando o exercício da autoridade. De acordo com o Ministro, tal valor integra as cláusulas pétreas como garantia dos direitos fundamentais e, ainda que não depositado de forma expressa no texto constitucional, é um valor ínsito ao Estado de Direito. Com base nos ensinamentos do constitucionalista português, relembrou o subprincípio da proteção na confiança das leis, que preserva a previsibilidade dos efeitos jurídicos diante de leis juridicamente estáveis e de atos governamentais incidentes sobre os direitos dos cidadãos. De fato, os parlamentares efetuaram suas trocas de partido com suporte nas normas, na jurisprudência vigente e em conformidade com o melhor entendimento da mais alta Corte de Justiça, sendo, por conseguinte, necessário respeitar as situações consolidadas ${ }^{527}$.

O Ministro Lewandowski destacou que as trocas partidárias não se efetuaram clandestinamente, porém em conformidade com os procedimentos legais vigentes $^{528}$, de acordo com os quais a mudança de partido deve ser comunicada de modo oficial à Justiça Eleitoral. Com base nos arts. 21 e 22 da Lei 9096/95, o desligamento da legenda deve ser informado por escrito à diretoria do partido, bem como ao juiz da respectiva zona eleitoral, que averiguará eventuais irregularidades. O Ministro frisou, ademais, que não se exige motivação por parte do Deputado do ato de desvinculação do partido pelo qual se elegeu. Esses são os dispositivos positivados no ordenamento em vigor.

${ }^{526}$ P. B. CARVAlHO, O princípio da segurança jurídica em matéria tributária, in Ciência Juridica, Ano VIII, vol. 58, jul/ago 1994, p. 51-55, APUD Min. Ricardo Lewandowski in STF, Pleno, MS 26.602-DF, rel. Min. Eros Grau, 04.10.07, DJE 17.10.08. Citado pelo Min. Lewandowski, afirma o autor Paulo de Barros Carvalho que a segurança jurídica é, por excelência, um sobreprincípio”. Sobre segurança jurídica e o princípio da confiança do cidadão cf. J. J. G. CANOTILHo, Direito Constitucional, 6a . ed., Almedina, Coimbra, 1995 p. 371-373.

527 O Ministro Lewandowski entendeu que ao se levar às últimas consequências os efeitos da decisão da Corte Eleitoral sobre a perda do mandato, diante do fato de que, na vigência da Constituição de 1988, mais de mil parlamentares já mudaram de partidos, "os atos por eles praticados poderiam ser havidos como irremediavelmente nulos", pois, de acordo com o entendimento de que a Carta Magna alberga princípios neste sentido e a perda do mandato decorre implicitamente do texto constitucional, "no momento que trocaram de partido, os seus mandatos já pertenceriam, de pleno direito, aos respectivos suplentes". O Ministro Celso de Mello rebateu o argumento, mostrando que a doutrina e a jurisprudência da Corte apontavam a solução para situações como a delineada pela aplicação da teoria da investidura aparente do agente estatal. O Ministro Peluso comparou com a solução dada pela Corte a respeito da prisão civil dos fiduciantes em alienação fiduciária. O Ministro Lewandowski pareceu não se contentar com os contraargumentos, porém seu posicionamento não encontrou maior respaldo pelos colegas, tampouco se estendeu o debate sobre a questão. STF, Pleno, MS 26.602-DF, rel. Min. Eros Grau, 04.10.07, DJE 17.10.08.

${ }^{528}$ TSE, Res. N. 21.574, rel. Min. Raphael de Barros Monteiro Filho, 27.11.03, DJ 12.12.03. 
Não obstante, entendeu o Ministro Celso de Mello, que encabeçou a corrente majoritária, estar prestigiando a segurança jurídica e o princípio da confiança ao considerar que as trocas partidárias ocorridas anteriormente à resposta do TSE, estavam legitimadas pelos precedentes jurisprudenciais, portanto, prévia e legalmente consolidadas, e que, diante da ruptura de um paradigma, requereu a fixação de limites para vigência da nova diretriz. Contudo, discordou do parecer emanado pela Procuradoria-Geral da República, que propusera a aplicação da nova orientação a partir da legislatura seguinte, em atenção à anterioridade da lei eleitoral, consagrada no art. 16 da Constituição vigente. Para o Ministro relator do MS 26.603, o ponto de inflexão a delimitar a eficácia da nova jurisprudência seria a resposta feita em tese pelo TSE em março do mesmo ano, no que foi seguido pela maioria. Tal solução se revelou deveras oportuna para os casos concretos em julgamento, à medida que todos os parlamentares litisconsortes passivos nos mandados de segurança analisados - a exceção da deputada Federal Jusmari Oliveira ${ }^{529}$ - haviam efetivado sua migração em data anterior à resposta à Consulta efetuada perante a Corte Eleitoral (a maior parcela destes Deputados o fez, inclusive, a menos de um mês da decisão referida). E, assim, tal proposição permitiu, de modo confortável à maioria dos Ministros, indeferir os mandados impetrados pelo PSB e pelo PSDB $^{530}$ e livrar os Deputados litisconsortes passivos da perda do mandato. Excluindo-se a grande parte dos Deputados trânsfugas deste risco, contornava-se outro problema: o da eventual declaração de perda de mandato eletivo de forma automática - sem o devido processo legal.

Dos três votos que desautorizaram a manutenção da vaga pelo partido ${ }^{531}$, apenas o Ministro Joaquim Barbosa se manifestou de forma subsidiária, negando a segurança e acompanhando a sequência estabelecida pelo Procurador-Geral da República para o deslinde da questão. Disse o Ministro que, caso a maioria da Corte optasse pela

529 De acordo com as informações apresentadas aos autos dos mandados de segurança em análise, a desfiliação da deputada teria sido efetivada dias após o pronunciamento do TSE que estabeleceu a data limite para a desfiliação sem pena. Todos outros litisconsortes passivos dos três mandatos de segurança efetuaram suas trocas antes da data marcada. Do início da legislatura em 2007 até fins de setembro do mesmo ano 42 deputados trocaram de partido. Nos dois primeiros dias de legislatura, 9 deputados já haviam migrado ou para o PAN ou para o PR. Após a o "marco zero" (data de 27/3/07), 17 deputados passaram a outra legenda, estando sujeitos, conforme decisão do STF, a requerimento da vaga pelos partidos de origem. STF, Pleno, MS 26.602-DF, rel. Min. Eros Grau, 04.10.07, DJE 17.10.08. V. Quadro N. 4 neste capítulo.

${ }^{530}$ Destaque para a posição do Ministro Carlos Britto que votou pela concessão da segurança, declarando o direito líquido e certo dos impetrantes reaverem todas as vagas pleiteadas, inadmitindo, portanto, a data da decisão do TSE como marco inicial inibidor das trocas, retroagindo, deste modo, presumidamente, ao início da legislatura. STF, Pleno, MS 26.602-DF, rel. Min. Eros Grau, 04.10.07, DJE 17.10.08. STF, Pleno, MS 26.603-DF, rel. Min. Celso de Mello, 04.10.07, DJE 19.12.08.

${ }^{531}$ Votos dos Ministros Joaquim Barbosa, Ricardo Lewandowski, Eros Grau. STF, Pleno, MS 26.602-DF, rel. Min. Eros Grau, 04.10.07, DJE 17.10.08. STF, Pleno, MS 26.603-DF, rel. Min. Celso de Mello, 04.10.07, DJE 19.12.08. 
concessão do writ, declarava seu voto subsidiário no sentido de que os efeitos da decisão fossem ex nunc e não retroagissem à decisão do TSE, pretendendo, deste modo, primordialmente, atender à segurança jurídica, além de atentar para o fato da resposta da Corte Eleitoral ser anterior ao ato da autoridade ora impugnado objeto de análise dos mandados. Por fim, repetiu o raciocínio dos colegas que o acompanharam, segundo o qual a jurisprudência vigente até o julgamento do Supremo legitimara as trocas ocorridas até tal data, portanto, não haveria razão para retroagir.

Neste ponto, cabe pontuar que o princípio da segurança jurídica, conforme relata M. HERMAN SALEM CAGGIANO, repousa na noção de prévio conhecimento da lei e do modo de sua aplicação e ganha planos cada vez mais notórios, pois destinados a evitar as incertezas decorrentes da aplicação do direito no tempo. ${ }^{532}$ Em concordância com as razões do Ministro Lewandowski, M. Herman Salem CagGiano confirma ser este considerado um macro princípio, composto de princípios atinentes à qualidade do direito (como o da claridade da lei, da acessibilidade, da eficácia e da efetividade) e da previsibilidade do direito (como os princípios da irretroatividade, da proteção dos direitos adquiridos, da confiança legítima e da estabilidade das relações contratuais). Assume, segundo a autora, "o status de elementos imprescindíveis para a correta análise da conformização de ato ou norma do Poder Público aos preceitos maiores da Constituição.” ${ }^{533}$ E o que garante a segurança jurídica perante as alterações normativas são os já relatados procedimentos para mudança constitucional via emenda, bem como a própria hierarquização das normas, decorrente da supremacia da Constituição.

Por sua vez, N. Bоввіо procura enfatizar que o princípio basilar da segurança jurídica está intimamente ligado à estrutura da democracia, à medida que uma de suas principais características é a manutenção das "regras do jogo" 534 . Essa noção de N. BOBBIO corresponde exatamente ao ditado popular: "o combinado não é caro", denotando que não se deve gerar elementos de imprevisibilidade durante o decorrer do "jogo" (que aqui pode ser lido como sendo a legislatura). Além do mais, existem normas para alterar as regras em uma democracia. Essas normas devem ser respeitadas em relação à legalidade, competência e anterioridade, todos componentes do princípio da segurança jurídica.

\footnotetext{
532 M. HeRman SALEM CAGgIANO, Legislação eleitoral e hermenêutica política x segurança jurídica, Cláudio Lembo (coord.), Barueri, Manole/CEPES, 2006, p. 17-18.

${ }^{533}$ M. HeRMAN SALEM CAGGIANO, Legislação eleitoral e hermenêutica política x segurança jurídica, cit., p, 19.

${ }^{534}$ N. BoBBio, O futuro da democracia, cit., p. 77-78.
} 
E. S. RAMOS discorre sobre a importância da segurança jurídica na evolução da jurisprudência do STF. Para o professor, essa se irradia sob três aspectos. O primeiro se configura no respeito aos parâmetros jurídicos normativos. O afastamento desses no desempenho de sua função leva a corte a um perigoso ativismo. Em segundo lugar, vem o uso cauteloso que se deve fazer da aplicação dos princípios. De acordo com o jurista, o abuso excessivo da principiologização da Constituição, leva à condenável criação normativa pura. $\mathrm{O}$ terceiro elemento se traduz em um padrão de evolução das decisões, que, empiricamente se observa não estar sendo respeitado pela Corte Suprema. Cita E. S. RAMOS os exemplos dos Mandados de Injunção 708 e 721, que trazem decisões discrepantes em curto intervalo de tempo. O primeiro, de relatoria do Ministro Gilmar Mendes, desenha uma solução para o direito de greve, caracterizando um processo objetivo, cujas decisões se propagarão em termos abstratos, ao determinar a aplicação das leis que regem os casos privados para todos os servidores públicos. Já o MI $721^{535}$, de agosto de 2007, relatoria do Ministro Marco Aurélio, decidiu sobre a aposentadoria especial denotando efeitos subjetivos da decisão. $\mathrm{O}$ autor atribui tal divergência à falta de diálogo com a doutrina, somada à sobrecarga de trabalho da Suprema Corte ${ }^{536}$.

Como relata M. Herman Salem Caggiano, tudo leva a crer que a segurança jurídica fora mesmo relegada a segundo plano, ao menos em quatro oportunidades, quando "algumas medidas foram implementadas à margem de qualquer reorientação constitucional, mediante ação pontual da Justiça Eleitoral". 537

E. S. RAmos comprova a importância de se observar o preceito da segurança jurídica na busca da instabilidade das instituições pátrias, pois o plano em que se encontra o Supremo Tribunal está contido no plano das instituições democráticas, assim como os partidos políticos também estão. Da assertiva do autor decorre a necessidade de preservação e melhoramento contínuo desses pilares da democracia, em perfeita harmonia, sem gerar desequilíbrios que fortaleçam determinados institutos - como os partidos políticos - em detrimento de preceitos fundamentais do ordenamento jurídico.

\footnotetext{
${ }^{535}$ STF, Pleno, MI N. 721/DF, rel. Min. Marco Aurélio, 30.08.07, DJE 30.11.07.

${ }^{536}$ Considerações feitas em palestra proferida no XVIII Encontro de Direito Constitucional, E. S. RAMOS exemplificou o ponto justamente com a decisão do Supremo e do TSE sobre a fidelidade partidária, demonstrando que a Corte procurou resolver a questão com base em um princípio genérico do sistema proporcional.

${ }_{537}$ M. HERMAN SALEM CAGGIANO, A fenomenologia dos trânsfugas no cenário político-eleitoral brasileiro, cit., p. 219-250.
} 


\title{
3.5.6 Ativismo judicial e a interferência entre os Poderes
}

A evolução da jurisprudência eleitoral carrega consigo outro tema atual e de constante polêmica ${ }^{538}$ : o ativismo do Poder Judiciário brasileiro, com destaque para a hiperatividade da Suprema Corte, acompanhada pela atuação em igual vetor do Tribunal Superior Eleitoral.

De acordo com E. S. RAMOS,

\begin{abstract}
"por ativismo judicial, deve-se entender o exercício da função jurisdicional para além dos limites impostos pelo próprio ordenamento que incumbe, institucionalmente, ao Poder Judiciário fazer atuar, resolvendo litígios de feições subjetivas (conflitos de interesse) e controvérsias jurídicas de natureza objetiva (conflitos normativos)." 539
\end{abstract}

O ativismo judicial é marcante nas decisões objeto de estudo do segundo Capítulo deste trabalho, que revelam o modo de operação do TSE em seus recentes pronunciamentos a respeito das mais diversas matérias. Por sua vez, o Supremo Tribunal deixou sua marca não somente no julgamento da fidelidade partidária ${ }^{540}$, porém, principalmente nesta ocasião, fez denotar o alargamento do seu campo operacional. Tanto assim, que o autor confere especial destaque à questão da fidelidade partidária em sua obra, frisando que

\begin{abstract}
"Ainda mais nítida é a incursão ativista nos julgados sobre perda de mandato por desfiliação partidária, na medida em que se procedeu ao desdobramento ou reforço de um princípio constitucional (o princípio da representação proporcional), sem se atentar para a necessidade de obrigatória intervenção de cunho normativo, da alçada do Poder Constituinte de revisão ou do legislador ordinário.." 541 (grifos nossos)
\end{abstract}

Destarte, necessário pontuar que uma das mais graves consequências deste movimento ativista é o abalo do equilíbrio entre os poderes. Como alerta E. S. RAMOS, uma das principais implicações do princípio da separação dos Poderes se revela

\footnotetext{
${ }^{538}$ O tema do ativismo judicial foi o mote central do XVIII Encontro de Direito Constitucional, promovido pela Associação Brasileira de Constitucionalistas - "Instituto Pimenta Bueno", entre 24 e 26 de setembro de 2009, na Faculdade de Direito da Universidade de São Paulo e trouxe a linha de frente do pensamento jurídico das mais diversas correntes que analisam a atuação dos Tribunais nacionais.

${ }_{539}$ E. S. RAMOS, Parâmetros dogmáticos do ativismo judicial em matéria constitucional, cit., p. 264.

${ }^{540}$ Cita-se ainda, como exemplo desse expansivismo, o entendimento firmado pela Corte sobre o direito de greve dos servidores público, a doutrina pátria do habeas corpus, a proscrição ao nepotismo e a implementação de direitos sociais. Cf. E. S. RAMOS, Parâmetros dogmáticos do ativismo judicial em matéria constitucional, cit., V. Seção II - "O Ativismo na recente jurisprudência do STF”, p. 188-227.

${ }^{541}$ E. S. RAMOS, Parâmetros dogmáticos do ativismo judicial em matéria constitucional, cit., p. 270.
} 
"na manutenção dos órgãos do Judiciário nos limites da função jurisdicional que lhes é confiada e para cujo exercício foram estruturados" 542 .

Muito se indaga sobre as motivações que impulsionaram o Judiciário a agir suprindo a legislação ${ }^{543}$. Entre essas, destacam-se a inoperância e a ineficiência dos Poderes Legislativo e Executivo em suprirem as necessidades sócio-econômicas ao Estado de Direito. A sociedade parece ter encontrado seu salvador contra a paralisia do sistema público-estatal. De um lado, um Poder Executivo cujo braço operacional é a Administração Pública, caracterizada pela lentidão, burocracia, ineficiência, incapacidade e demais defeitos da tão difamada máquina administrativa. De outro lado, o Poder Legislativo, que de longa data vem perdendo espaço para o Executivo, agora cede lugar ao Judiciário. Parece sim guardar íntima culpa pela efervescente produção jurisdicional - mormente em matéria eleitoral ${ }^{54}$ - observada nos últimos anos em nossa nação. Talvez não a justifique, mas certamente é listada como uma das principais causas do ativismo do Poder Judiciário a lacuna deixada pelo Legislativo.

Não obstante, não residem as mencionadas razões tão somente nessa "desatenção" das casas legislativas. Pesadas críticas incidem sobre a qualidade da produção legislativa. Conforme consigna com maestria RUBENS NAMAN RIZEK JUNIOR ${ }^{545}$, uma de suas facetas é, paradoxalmente, a inflação legislativa decorrente do modelo adotado pelo processo legislativo, impregnado de certa preguiça em revisar as normas positivadas existentes e adaptá-las à realidade. Diante da premência de agilidade dos tempos da informação on line, torna-se mais fácil editar nova lei do que adequar as regras existentes aos novos anseios. Notórias são as oportunidades em que as normas são editadas para solucionar problemas específicos ou ainda resolver "algum clamor social efêmero", empregando-se os termos de R. NAMAN RIZEK JUNIOR ${ }^{546}$.

\footnotetext{
${ }^{542}$ E. S. RAMOS, Parâmetros dogmáticos do ativismo judicial em matéria constitucional, cit., p. 264.

${ }^{543}$ E. S. RAMOS, discorre amplamente sobre os fatores de impulsão ao ativismo judicial, apontando, por exemplo, o modelo de Estado intervencionista, a intensificação do controle abstrato de normas e o neoconstitucionalismo como incentivadores do ativismo. Cf. Parâmetros dogmáticos do ativismo judicial em matéria constitucional, cit., p. 270-271.

${ }^{544}$ Exemplo encontrado fora do âmbito eleitoral está nos Mandados de Injunção que decidiram a questão da greve dos servidores públicos. A jurisprudência do STF apontava inicialmente apenas a necessidade de regulamentação. Todavia, ao julgar o MI 721/DF, entendeu a Corte que poderia aplicar as normas reguladoras do direito de greve privado ao servidor público, suprindo nitidamente a paralisia do Legislativo em produzir norma nesse sentido. STF, Pleno, MI N. 721/DF, rel. Min. Marco Aurélio, 30.08.07, DJE 30.11.07.

${ }^{545}$ R. NAMAN RIZEK JUNIOR, Processo de consolidação e organização legislativa, Tese de doutorado defendida na Faculdade de Direito da Universidade de São Paulo em 2009, p. 301.

${ }^{546}$ R. NAMAN RIZEK JUNIOR, Processo de consolidação e organização legislativa, cit, p. 301-302.
} 
Seja pela facilidade de legislar, seja pela necessidade de "marcar posição eleitoral", como aponta o autor, o procedimento legislativo nacional gera um efeito bola de neve, pois quanto maior o número de leis, mais complexo e tormentoso buscar-se a atualização destas, mesmo porque a enorme quantidade de normas "transformou o ordenamento jurídico em um cipoal, em que as normas se sobrepõem, se repetem e se conflitam, prejudicando a compreensão, a aplicação e a efetividade do Direito Objetivo", uma verdadeira "babel jurídica" que nubla a vontade geral que legitima a lei e nela deveria estar refletida $^{547}$. Ademais, a dificuldade de composição das forças sociais e acomodação das minorias, somadas aos não raros casos de atendimento a grupos de influência ou oligarquias, castiga igualmente a qualidade da lei, fazendo com que essas sejam editadas com previsões genéricas e lacunosas, de modo a serem aprovadas sem maiores obstáculos. Em suma, o resultado desse processo é "uma lei qualitativamente ruim" "548, que abre espaço para o poder atualmente mais atuante impor-se e determinar a solução, não somente para o caso concreto, como também abstratamente e erga omnes.

Técnica e juridicamente falando, nenhuma das razões acima apontadas justificam a invasão do Judiciário no campo dos outros Poderes. Todavia, certas decisões acabam por agradar a população em termos gerais, pois esta anseia cada vez mais por algum grau de efetividade das políticas públicas e de suas leis. Tanto assim é que, quando decide a Corte Maior que a Administração deve agir, por exemplo, provendo remédios à população, pouco temor causam ao cidadão comum tanto uma eventual quebra de orçamento, de um lado, quanto, de outro, a intromissão nos elementos discricionários das políticas públicas pelo Judiciário. O julgamento mais recente da fidelidade partidária é típico exemplo da atuação voltada a atender os desejos da população por moralização e ética na política, que retirou do Legislativo - ao menos momentaneamente - a competência para regulamentar a questão. Desta feita, novamente adentra-se no mérito da proporcionalidade e razoabilidade das normas do ordenamento, escapando à função estrita de julgamento quanto à legalidade ou constitucionalidade. Esta sim, atribuição precípua fornecida pelo texto constitucional à Corte Suprema.

Não é outra a opinião do Ministro do STF Eros Grau, que recupera ensinamentos básicos para demonstrar sua indignação com a recente atuação das cortes em

\footnotetext{
${ }^{547}$ R. NAMAN RIZEK JUNIOR, Processo de consolidação e organização legislativa, cit., p. 302-303.

${ }^{548}$ R. NAMAN RIZEK JUNIOR em palestra proferida no XVIII Encontro de Direito Constitucional, promovido pela Associação Brasileira de Constitucionalistas - "Instituto Pimenta Bueno" em 26.09.09 na Faculdade de Direito da Universidade de São Paulo.
} 
desempenho da atividade interpretativa. De acordo com o magistrado da Corte Suprema ${ }^{549}$, o valor da segurança jurídica é assegurado pelo Direito Moderno, produto das revoluções francesa e industrial e se caracteriza por sua racionalidade, mormente na tomada de cada decisão jurídica, por intermédio da aplicação de uma proposição abstrata a um caso concreto, conforme pressupostos jurídicos - que fornecem previsibilidade e, por conseguinte, segurança. O oposto se instala quando a Corte Suprema extravasa sua função de controlador da Constituição e passa a gerir a razoabilidade e a proporcionalidade das leis, para o qual não possui legitimação. O Ministro ensina que razoabilidade e proporcionalidade não são princípios, mas pautas de atuação, critérios. Princípios podem ser contrapostos. Razoabilidade e proporcionalidade não encontram antagônicos a serem opostos. São simplesmente aplicados diretamente e necessariamente.

Ainda para aqueles que consideram plenamente justificada a próatitividade do Supremo pelos motivos aqui expostos, outro componente do ativismo judicial não escapa ao debate. Fala-se, aqui, da forma com que o Supremo Tribunal conduz sua atividade exegética. Este tema é reiteradamente trazido à baila no presente estudo, pois da interpretação expansiva ora promovida por esta Corte surgem os efeitos característicos do ativismo judicial que impregnou a jurisprudência eleitoral recente. Nitidamente, por meio das ferramentas hermenêuticas, o Judiciário busca superar os obstáculos à sua mais ampla atuação, positivando normas em verdadeira atividade produtiva, extrapolando seus limites criativos dados pela exegese e suprindo o papel do legislador positivo. Como bem pontuou E. S. RAMOS, a discricionariedade judicial deve florescer "no espaço que os balizamentos normativos autorizam a se movimentar" $" 550$.

Não obstante, é certo que, como afirma o Ministro Eros Grau, a hermenêutica requer a criação normativa ${ }^{551}$, pois o direito exige sempre a presença de um intérprete. O "ser" atualiza o "dever-ser", diz o Ministro. Mas da assertiva não se deve deduzir que há um campo sem fronteiras à atuação exegética. A solução se encontra, para

\footnotetext{
${ }^{549}$ E. GRAU, $O$ direito posto e o direito pressuposto, $7^{\mathrm{a}}$ ed., Malheiros, São Paulo, 2008. A ética da legalidade prevê que o juiz deve julgar conforme a lei (p. 288-298). O magistrado tem discricionariedade, mas esta não pode ensejar interpretação contrária à lei (p. 209-210). Palestra proferida no XVIII Encontro de Direito Constitucional, promovido pela Associação Brasileira de Constitucionalistas - "Instituto Pimenta Bueno" em 26.09.09 na Faculdade de Direito da Universidade de São Paulo.

${ }^{550}$ E. S. RAMOS, Parâmetros dogmáticos do ativismo judicial em matéria constitucional, cit., p. 264.

${ }^{551}$ E. GRAU, Palestra ministrado no XVIII Encontro de Direito Constitucional, promovido pela Associação Brasileira de Constitucionalistas - "Instituto Pimenta Bueno" em 26.09.09 na Faculdade de Direito da Universidade de São Paulo. V. também a obra Ensaio e discurso sobre a interpretação - Aplicação do Direito - $4^{\text {a }}$ ed., São Paulo, Malheiros, 2006, p. 38. Segundo o autor: “(...) a interpretação do direito tem caráter constitutivo - não meramente declaratório, pois - e consiste na produção, pelo intérprete, a partir de textos normativos e dos fatos atinentes a um determinado, de normas jurídicas a serem ponderadas para a solução desse caso, mediante a definição de uma norma de decisão.”
} 
este jurista, na diferenciação existente entre 'texto' e 'norma'. Esta é fruto da interpretação promovida sobre o texto, obra do juiz intérprete, que busca extrair do texto positivado o correto entendimento a ser aplicado ao caso concreto em julgamento, tomando o texto legal, somando a realidade e gerando as normas gerais. O próprio texto da Constituição é um conjunto de possibilidade de normas. Mas o juiz pode ir mais além: após a produção da norma jurídica geral, decidirá um caso concreto. Nesse instante está o magistrado a produzir normas de decisão, função que lhe é reservada ${ }^{552}$. É nesse momento que aplicam as pautas de razoabilidade e proporcionabilidade e não na primeira fase do processo hermenêutico, quando trabalha sobre o texto positivado para produzir normas jurídicas gerais.

O significado dos textos escritos varia no tempo e no espaço, nas dimensões histórico-culturais, fazendo com que a realidade se retrate pela interpretação. Porém, disso não decorre que o juiz positivará nova norma, relegando o texto positivado ou atribuindo-lhe sentido inverso ou diverso do que está estampado. Dessa lógica se extrai que o texto é o limite da atividade interpretativa, o que não pode ser confundido com o método gramatical de interpretação. São coisas distintas. A aplicação dos métodos hermenêuticos sistêmico, axiológico e histórico, a par do método gramatical, não prescinde dos limites fornecidos pelo texto positivado. Não lhe dá asas para interpretar-se contra o texto. Propõe o Ministro Eros Grau que, para garantia da segurança jurídica e das instituições democráticas do Estado de Direito, não se extravase do texto positivado, propagando que "sejamos cada vez mais positivistas, segundo os parâmetros jurídicos instalados".

Quando se procede de modo diverso, frisa o Ministro, se está definitivamente invadindo o campo da produção legislativa resguardada constitucionalmente ao Poder correlato. Metaforicamente adverte o Ministro que o Supremo está "atravessando a praça" ${ }^{\text {"553 }}$, ao extrapolar o controle de constitucionalidade e adentrar em um controle de razoabilidade e proporcionabilidade. Esse modo de proceder leva à formulação arbitrária de juízos de valor, que foi o que nitidamente se passou na decisão sobre a fidelidade partidária.

Resvalando-se novamente na questão da legitimação do STF, percebe-se que há confusão no papel institucional de guardião da Constituição, para o qual a Corte foi

${ }^{552}$ V. os comentários a respeito da dissociação lógico-temporal entre enunciado normativo e norma de decisão, colocado por E. S. RAMOS. Cf. Parâmetros dogmáticos do ativismo judicial em matéria constitucional, cit., p. 262. V. também Nota N. 372, Cap. 2 desta dissertação.

${ }^{553}$ E. GRAU, Palestra ministrada no XVIII Encontro de Direito Constitucional, promovido pela Associação Brasileira de Constitucionalistas - "Instituto Pimenta Bueno" em 26.09.09 na Faculdade de Direito da Universidade de São Paulo. 
legitimada pela própria Carta Magna, em oposição ao papel de produtor das normas que devem constar de nosso ordenamento, brindado ao Poder Legislativo. A legitimação dessa função legislativa advém do voto popular, como mecanismo de transferência da soberania aos representantes, a quem incumbirá a elaboração das leis, tida em seu conceito clássico, de reflexo dos anseios da maioria e fruto de debates que buscam o consenso, elemento típico do processo democrático.

\subsubsection{A natureza da representação política em face da decisão do STF}

Um dos principais problemas que se identifica na decisão tomada por nossas cortes afeta diretamente a natureza do mandato representativo. Como nos ensina $\mathrm{M}$. Herman SAlem CAgGiano, a representação política encontra suas bases não só no momento eleitoral, mas também na figura do representante eleito e na responsabilidade que esse assume perante a nação. A questão, que não foi analisada a fundo nos votos proferidos, diz respeito à prestação de contas dos parlamentares, ou seja, à própria natureza do mandato eletivo. Afinal, quem responde politicamente pelo exercício do mandato? $\mathrm{O}$ partido ou o representante eleito? Deve-se buscar saber a quem representam e a quem ou ao que permanecem vinculados aos eleitos. A vinculação ao partido que se dá no momento da filiação se manteria intacta mesmo após as eleições? Mais além: estariam os Deputados vinculados aos seus eleitores ou às suas responsabilidades, de manter condutas alinhadas com toda a sociedade, ou seja, com a nação?

Conforme apresentado no capítulo inicial desta dissertação, tais respostas são fornecidas pela teoria da representação política e apontam a opção do STF pelo mandato vinculativo ou imperativo, que liga o representante aos seus eleitores e que se opõe ao mandato livre. Apenas o mandato desvinculado reflete a forma predominante nas democracias ocidentais nos últimos dois séculos, evolução da modelagem original da teoria da representação política. Hoje, o mandato assume a configuração delineada por CARRÉ DE MALBERG e detalhadamente narrada por M. HERMAN SALEM CAGGIANO ${ }^{554}$, apresentando que os parlamentares devem representar toda a nação, preservando sua autonomia em

${ }^{554}$ M. HeRman SAlEm CAGgiano, A fenomenologia dos trânsfugas. O cenário político-eleitoral brasileiro, cit. 
relação à agremiação que os elegeu, inadmitindo, pois, qualquer tipo de vínculo o instituto da representação política.

Em conclusão a esse ponto, percebe-se que a interpretação sistêmica desempenhada por nossos Tribunais no deslinde da questão, olvidou-se de enveredar sobre a essencial natureza da representação política, que, por certo, distanciaria qualquer tentativa de reconhecimento do vínculo com o partido político. Oportuno notar: o mesmo argumento utilizado pelo Tribunal constitucional espanhol, aplicado para julgar inconstitucional a lei que possibilitava ao partido retirar o mandato do parlamentar, foi aplicado para justificar decisão em sentido oposto de nossas Cortes. A Corte espanhola, com o fundamento de que os representantes "são titulares de uma função pública",555, concluiu que os partidos não podem por termo a essas funções. A natureza pública da função representativa foi aplicada para justificar decisão em sentido oposto, pelo STF, cujo entendimento foi que, exatamente por ser função pública, o representante deveria perder o mandato em favor do partido.

\subsection{Os desdobramentos decorrentes da decisão do STF e o questionamento da constitucionalidade da Resolução N. 22.610/07 do TSE}

Após julgamento dos referidos mandados de segurança pelo STF e em cumprimento a decisão deste, a Corte Eleitoral, com fundamento na competência que lhe é atribuída pelo art. 23, XVII, do Código Eleitoral, disciplinou o procedimento para decretação de perda de cargo eletivo, incluindo o de justificação para desfiliação partidária, por meio da Resolução N. 22.610, em 25 de outubro de 2007, relatoria do Ministro Cezar Peluso.

A indigitada Resolução cria o processo pelo qual o partido político poderá provocar a Justiça Eleitoral, para que esta decrete a perda do mandato eletivo, diante de comprovada ausência de razão para a desfiliação. Em contraparte, estabelece

\footnotetext{
555 O excerto trazido por M. HERMAN SALEM CAGGIANo dá luz a questão da representação política, bem como à natureza pública da função dos parlamentares: "Infringe frontalmente o direito dos cidadãos de participar dos assuntos públicos por intermédio de seus representantes. Uma vez eleitos, os representantes não representam a quem os sufragou, porém a todo o corpo eleitoral e portanto são titulares de uma função pública a que não podem por um termo final decisões de órgãos que não são órgãos do Estado." $A$ fenomenologia dos trânsfugas. O cenário político-eleitoral brasileiro, cit.
} 
também a possibilidade do mandatário, que pretende desfiliar-se, obter a declaração de justa causa, para que carregue consigo, deste modo, o mandato eletivo. Isso se processaria justamente quando se incidir em uma das hipóteses de motivação para o abandono de legenda - ampliadas pela Resolução - a saber: I) incorporação ou fusão do partido; II) criação de novo partido; III) mudança substancial ou desvio reiterado do programa partidário; IV) grave discriminação pessoal.

O próprio TSE, seguindo diretriz contida nos votos do STF nos mandados de segurança que analisaram a fidelidade partidária, autodeterminou sua competência para processar e julgar causas cujo objeto seja mandato Federal, restando residualmente aos Tribunais Regionais dos Estados as demais causas ${ }^{556}$. Para o autor T.T. CERQueIRA, criou-se, por determinação do STF nos mandados ora estudados, "um procedimento inexistente numa Justiça incompetente" ${ }^{557}$. Sob a denominação de procedimento "administrativo-eleitoral", invadiu-se a competência privativa da União ${ }^{558}$, pois, no fundo, trata-se de matéria atinente ao processo civil. Além do mais, retirou a competência da Justiça Comum, a quem sempre coube julgar a perda de mandato após o prazo de 15 dias da diplomação, transferindo-a para a Justiça Eleitoral. A fixação da competência não se deu em razão do local da diplomação do candidato, mas de acordo com a esfera de exercício do mandato. Caberá ao TRE julgar mandatos municipais e estaduais e ao TSE mandatos Federais.

A incongruência decorre do próprio posicionamento prévio da Corte Eleitoral, que mantinha até então a atuação da Justiça Comum em casos de perda de mandato. A Resolução N. 13.961/93 ${ }^{559}$ previa que "a competência da Justiça Eleitoral cessa com a diplomação do candidato eleito”. A Resolução N. 14.139/94 ${ }^{560}$ apontava que “a jurisprudência da Corte é no sentido de que a perda do mandato é tema pertinente ao direito constitucional, Federal ou estadual, estranho, portanto, à competência da Justiça Eleitoral”. Há, ainda, precedentes na Resolução N. 12.279 e nas posteriores de números 17.643 e 18.848. Por certo, sabia-se que a Justiça Comum resolvia sobre titularidade do mandato eletivo durante o exercício do mandato ${ }^{561}$. Resultou do pronunciamento do STF

\footnotetext{
${ }^{556}$ TSE, Res. N. 22.610, rel. Min. Cezar Peluso, 25.10.07, DJ 30.10.07, art. $2^{\circ}$.

557 T. T. CERQUEIRA, Fidelidade partidária e perda de mandato no Brasil: temas complexos, cit., p. 85.

${ }^{558}$ Art. 22, I, Constituição Federal da República do Brasil de 05.10.88.

559 TSE, Res. N. 13.961, rel. Min. Carlos Velloso, 26.10.93, DJ 24.11.93.

${ }^{560}$ TSE, Res. N. 14.139, rel. Min. Carlos Velloso, 07.04.94, DJ 23.05.94.

${ }^{561}$ Nesse sentido se pronunciou a Procuradoria Regional Eleitoral de São Paulo, em manifestação acostada aos autos do recurso 25.928 oferecido pelo PMDB ao TRE-SP. A douta Procuradoria, considerando incompetente a Justiça Eleitoral para decretar a perda de mandato parlamentar em face de desfiliação, sustentou que a Constituição prescreve as hipóteses em que se permite a impugnação do mandato (abuso de
} 
no MS 26.603 que a Justiça Eleitoral se tornaria competente para avaliar a perda de mandato por infidelidade partidária, mantendo-se inalterada a competência da Justiça Comum para os restantes casos de perda de mandato.

Impende igualmente assinalar que o TSE, ao atribuir caráter administrativo ao rito, desconsiderou a possibilidade de recurso na redação original da Resolução em comento, designando como única hipótese de manifestação da parte sucumbente o "pedido de reconsideração", instituto semelhante ao existente no juizado especial cível. Tais incongruências trazidas à tona pela Resolução em pauta não passariam despercebidas. Analisando a original da Resolução em tela, detectam-se alguns problemas:

a) a restrição à ampla defesa;

b) a incompatibilidade com a previsão do art. 121 da Constituição

Federal, que estabelece, no caput, a necessidade de lei complementar para regular a competência dos tribunais eleitorais;

c) A previsão do art. 121, que em seus $\S \S 3^{\circ}$. e $4^{\circ}$., dispõe serem em regra irrecorríveis as decisões do TSE, mas excepciona as que contrariarem a Constituição e as denegatórias de habeas corpus ou mandados de segurança (que são hipóteses não descartáveis a priori para o julgamento da perda de mandato eletivo); lista, ainda, as hipóteses de cabimento de recurso contra decisões dos TREs. Logo, o inicialmente previsto "pedido de reconsideração" afronta tais dispositivos constitucionais. Note-se, porém, que a redação original do art. 11 da Resolução N. 22.610/07 viria a ser alterada pela Resolução N. $22.733^{562}$, estabelecendo o cabimento dos recursos previstos no parágrafo $4^{\circ}$. do art. 121 CF/88 contra acórdão proferido pela Justiça Eleitoral;

d) a competência supletiva concorrente do Ministério Público Eleitoral que o autoriza ser autor da ação na omissão do partido político após 30 dias da filiação, tendo em vista decisão anterior do $\operatorname{STF}^{563}$ na qual entendeu a Suprema Corte ser o Parquet parte ilegítima para atuar no assunto verticalização das coligações, por ser matéria interna corporis. Ou seja, o MPE, ao invés de atuar como fiscal da lei tão somente - posição que

poder, corrupção ou fraude) e concede o prazo máximo de quinze dias após a diplomação. Assim também restou assentado no STJ após a decisão do STF acerca da fidelidade partidária. Cf. STJ, S1, Conflito de Competência: CC 88236 SP 2007/0170003-3, rel. Min. Castro Meira, 26.02.08, DJ 17.03.2008. Ementa: Conflito de competência. Ação ordinária. Infidelidade partidária. Perda do mandato eletivo. Competência. Justiça comum. Decisão interlocutória proferida por juiz estadual. Julgamento de agravo de instrumento. Competência do tribunal de justiça do estado. 1. "A competência da Justiça Eleitoral se exaure com a diplomação dos candidatos eleitos. A Justiça Comum é competente para apreciar e julgar ação declaratória de perda de mandato por infidelidade partidária”. Precedente: (STJ, CC 3024/SC, rel. Min. Francisco Peçanha Martins, DJU de 24.05.93).

562 TSE, Res. N. 22.733, rel. Min. Cezar Peluso, 11.03.08, DJ 27.03.08.

${ }^{563}$ STF, ADI N. 3.683, rel. Min. Ricardo Lewandowski, 05.04.06, DJ 20.04.06. 
lhe seria mais adequada no caso - assume a posição de substituto processual para pleitear vaga do partido que não teve interesse em requerê-la;

e) por fim, em se admitindo a natureza administrativa do procedimento, afastada fica a coisa julgada material, abrindo portas para discussão jurisdicional, mormente via mandado de segurança ou recurso extraordinário perante o STF, conforme jurisprudência do próprio $\mathrm{TSE}^{564}$.

Dispõe ainda o art. 10, da mesma norma, a decretação da perda do cargo pelo tribunal eleitoral competente, quando julgado procedente o pedido do partido abandonado pelo parlamentar. A decisão deverá ser comunicada ao presidente do órgão legislativo, determinando que se emposse o suplente no prazo de dez dias. Naturalmente, quando a ação se inicia pelo procedimento de justificativa de abandono de sigla, tendo o parlamentar já se desfiliado, a improcedência do pedido (considerando ter havido a correta citação dos litisconsortes passivos principalmente o partido de origem), levaria a necessidade de reconvenção pedindo a perda do mandato por desfiliação sem justa causa, dentro do prazo legal, não fosse o TSE vir a reconhecer, em julgamentos futuros de casos concretos, a natureza dúplice dessa ação.

\subsubsection{ADI 3.999 e ADI 4.086 - A constitucionalidade da Resolução N. 22.610/07 do TSE}

As patentes brechas para um questionamento de inconstitucionalidade da norma editada pelo TSE (Resolução N. 22.610) em 25 de outubro de 2007 ensejaram o manejo de duas ADI junto ao STF - tendo como requerido o próprio Tribunal Superior Eleitoral - que foram conjuntamente julgadas em 12 de dezembro de 2008. A primeira (ADI N. 3.999) foi proposta pelo PSC (Partido Social Cristão) e a segunda (ADI N. 4086) pelo Procurador-Geral da República ${ }^{565}$, que, conforme anteriormente estudado, havia se pronunciado nos autos dos mandados de segurança que decidiram sobre a fidelidade partidária, de maneira oposta aos votos majoritários. Não por simples contrariedade ao seu

\footnotetext{
${ }^{564}$ TSE, ARESPE N. 19.566, rel. Min. Raphael de Barros Monteiro Filho, 18.06.2002, DJ 13.09.02, de cuja ementa se extrai: “A decisão em procedimento administrativo da Justiça Eleitoral não faz coisa julgada quanto aos procedimentos de jurisdição contenciosa e jurisdicional.”

${ }^{565}$ STF, Pleno, ADI 3.999, rel. Min. Joaquim Barbosa, 12.11.08, DJE 17.04.09; STF, Pleno, ADI N. 4.086, rel. Min. rel. Min. Joaquim Barbosa, 12.11.08, DJE 17.04.09.
} 
parecer, mas antes por entender que a Resolução editada pelo TSE padecia igualmente de inconstitucionalidades, afrontando a Norma Maior em uma série de outros dispositivos.

Em resumo, foram as seguintes violações constitucionais arguidas:

a) Afronta ao art. $121 \mathrm{da} \mathrm{CF} / 88$, pois o art. $2^{\circ}$ da Resolução atribui aos Tribunais Eleitorais a competência para análise dos pedidos de perda do mandato por desfiliação partidária, desconhecendo a reserva feita à lei complementar para disciplinar o tema;

b) Inovação de matéria eleitoral, usurpando competência do Legislativo e do Executivo, tal como prevista nos arts. 22, I e 48 e 84, IV da Constituição;

c) Criação de diversas normas de índole processual, tal como requisitos da inicial, prazos processuais, provas, julgamento antecipado da lide, em violação à reserva contida igualmente nos arts. 22 , I e 48 e 84 , IV da Constituição;

d) Legitimação postulatória a terceiro interessado que não o partido político $^{566}$ e ao Ministério Público, em desatenção ao princípio da reserva legal estrita contida nos arts. $128, \S 5^{\circ}$. e 129 , IX, da CF/88;

e) Invasão da competência legislativa atentando contra a separação dos Poderes, inscrita nos arts. $2^{\circ}$. e $60, \S 4^{\circ}$., III da Carta Magna.

O relator da ADI N. 3.999, Ministro Joaquim Barbosa, que havia sido vencido no julgamento pelo STF da fidelidade partidária, pois sustentara a inexistência de previsão constitucional aliada à jurisprudência até então formada pela corte, bem como vencido quanto à modulação dos efeitos da decisão, proferiu o voto condutor dessa ação declaratória relembrando seu posicionamento relativamente à questão. Afirmou, todavia, que a necessária forma de atuação colegiada do Pleno daquela Corte, obrigava a todos a fidelidade às decisões emanadas, ainda que resguardadas as posições pessoais, tendo em

\footnotetext{
${ }^{566}$ A autorização para postular em nome próprio concedida ao suplente desafia a segurança jurídica, uma vez que a Res. N. 22.526/07, editada nos termos da resposta à Consulta N. 1.398, nada determinou sobre essa possibilidade, conforme relatou o Procurador-Geral da República em seu parecer. Ademais, argumentou ele, foi decidido que o mandato "pertence" ao partido. Cf. Parecer N. 3250/PGR, Ministério Público Federal, in STF, Pleno, MS 26.603-DF, rel. Min. Celso de Mello, 04.10.07, DJE 19.12.08.
} 
vista ser necessário evoluir dentro do que o Tribunal havia decidido, não cabendo voltar atrás, remoendo-se os mesmos pontos que foram, bem ou mal, ultrapassados ${ }^{567}$.

Nesse contexto, desenvolveu o relator longo raciocínio, que procuraria demonstrar, entre outros aspectos, que, diante da reforma da antiga jurisprudência, pouco sentido haveria em se certificar a possibilidade de perda do mandato diante da infidelidade se não fossem previstos os meios para concretizá-la, sendo certo que inexistia tal previsão no ordenamento. Por esse motivo, justificada estaria a atribuição de competência à Justiça Eleitoral para, por via de Resolução, disciplinar os ritos necessários, inclusive para produção de provas visando o discernimento da presença de justa causa para a desfiliação do eleito. Não obstante tal justificação - que seria decisiva para acompanhamento dos votos majoritários - o Ministro Joaquim Barbosa levanta uma série de questionamentos ${ }^{568}$ visando demonstrar que "em princípio, o Judiciário está mal equipado para resolver a instabilidade originada pela decisão da perda do mandato eletivo por infidelidade partidária." Tudo para comprovar a transitoriedade da decisão emanada pelo Supremo, pois, conforme entendimento emanado por este Ministro, "o debate legislativo é o ambiente adequado para resolver essas e outras questões, que são eminentemente políticas", sendo necessário ao juiz supremo atentar-se às "limitações institucionais próprias do Poder Judiciário". Com isso quis o relator, Ministro Joaquim Barbosa, confirmar que ao TSE competiria agir durante o silêncio do Legislativo - a quem o texto constitucional comete o "poder-dever de exercer a representação política que lhe foi outorgada e dispor sobre matéria eleitoral” - em caráter temporário e de exceção, perante a carência de meio capaz de garantir direito constitucional estabelecido via jurisprudência do Supremo. Desta forma, propugnou, em conclusão, que

"a atividade normativa do TSE recebe seu amparo da extraordinária circunstância de o Supremo Tribunal Federal ter reconhecido a fidelidade partidária como requisito para permanência em cargo eletivo e a ausência expressa de mecanismo destinado a

\footnotetext{
${ }^{567}$ Em que pese a declaração do relator ter sido elogiada por vários Ministros, entre eles Menezes Direito e Ellen Gracie, em várias oportunidades retomou-se o debate da questão de fundo da fidelidade partidária, repetindo-se as posições ora afirmadas no julgamento dos três notórios mandados de segurança decisivos sobre o tema. Isso mostra que o assunto ainda é tormentoso, mesmo para os Ministros do Colendo Tribunal. STF, Pleno, MS 26.603-DF, rel. Min. Celso de Mello, 04.10.07, DJE 19.12.08.

${ }^{568}$ São interessantes e novéis no debate as questões levantadas por Joaquim Barbosa acerca da questão da infidelidade. O Min. indagou: "a legitimação de terceiro (suplente) não tem potencial para fomentar conflitos orientados muito mais pelo interesse pessoal do que pelo legítimo interesse republicano (...)?”; “(...) qual a razão para excluir o eleitor?" (como legitimado para questionar a fidelidade); "não deveria haver um mecanismo para examinar a percepção do eleitor quanto à fidelidade do partido pelo qual se elegeu o candidato tido por insurgente às diretrizes fixadas pela ocasião do pleito?"; "O partido pode anuir com a migração e afastar a perda do mandato?”. Cf. STF, Pleno, ADI 3.999, rel. Min. Joaquim Barbosa, 12.11.08, DJE 17.04.09.
} 
assegurá-1o"569 , sendo, portanto, válidas as resoluções emanadas pelo TSE "até que o Congresso Nacional disponha sobre a matéria." ${ }^{570}$ (grifos no original)

O voto do relator foi integralmente acompanhado pelos Ministros Menezes Direito, Cármen Lúcia, Ellen Gracie, Carlos Britto, inclusive quanto à subsistência do julgado até o exercício da competência legislativa do Congresso Nacional regulamentando totalmente a matéria nos termos consolidados pelo Supremo Tribunal em respeito ao princípio da fidelidade partidária. Também acompanharam o voto do relator os Ministros Lewandowski, Mendes e Peluso, que ressaltaram que em precedente firmado no RE 197.917 (caso de "Mira Estrela" aqui estudado), o Supremo sugerira igualmente a regulamentação da matéria pelo TSE, para dar concreção à decisão daquele que possui eficácia irradiante por todo o ordenamento, o que o fez com base no mencionado art. 23, IX, do Código Eleitoral. Em outros termos, disseram os ilustres Ministros, nada mais fez o TSE além de buscar a eficácia da coisa julgada material de um acórdão da Suprema Corte, típica expressão de um devido processo legal, cuja fonte é, por essa razão, integralmente constitucional, não desbordando a Corte Eleitoral de sua competência.

Restaram vencidos os Ministros Marco Aurélio e Eros Grau, porém por razões sutilmente diferentes. O primeiro alegou que a Resolução objeto da ADI não se configurava ato normativo abstrato autônomo. Assentou o Ministro Marco Aurélio não haver normatização no campo do processo e do direito eleitoral substancial a desafiar a competência do Legislativo, mas antes mera reprodução de leis já existentes no ordenamento. Para ele, o TSE não legislou, pois essa Corte não tem "sequer competência para expedir instruções, consoante o inciso IX, do art. 23 do Código Eleitoral, necessárias à execução da Constituição Federal, e o Tribunal Superior Eleitoral não edita nem lei complementar nem lei ordinária."

Por sua vez, o Ministro Grau manteve sua posição de ataque à decisão do STF, mantendo-se fiel à sua posição exarada nos julgamentos da Suprema Corte. Entendeu ser a Resolução em análise "multiplamente inconstitucional", o que fez nos exatos termos do Procurador-Geral da República.

${ }^{569}$ STF, Pleno, ADI 3.999, rel. Min. Joaquim Barbosa, 12.11.08, DJE 17.04.09.

${ }^{570}$ STF, Pleno, ADI 3.999, rel. Min. Joaquim Barbosa, 12.11.08, DJE 17.04.09. 


\subsubsection{A competência do TSE}

Um dos principais pontos que para o Ministro Eros Grau configurava um "abuso de inconstitucionalidade" foi a incompetência do TSE para estabelecer a perda de mandato por infidelidade partidária. O Ministro frisou que o Código Eleitoral, em seu art. 23, IX, não prevê nada além da incumbência do TSE de "expedir as instruções que julgar convenientes à execução deste Código". Ainda no inciso XVIII do mesmo artigo, cabe à Corte "tomar quaisquer outras providências que julgar convenientes à execução da legislação eleitoral". Disto se infere seu poder regulamentar ${ }^{571}$, nos mesmos limites dados aos decretos e regulamentos baixados pela Presidência da República para execução das leis (art. 84, IV, CF), que o impedem inovar no ordenamento jurídico. Desconhece-se, de acordo com o Ministro, “autorização, ao TSE, ao Presidente da República, aos Ministros de Estado, senão para disporem sobre a execução das leis, secundum legem. Jamais para disporem contra ou praeter legem", o que conduziria a uma nítida transgressão da legalidade. O Ministro indagou da contemplação ao TSE do poder de expedir normas primárias, tal como o fez na Resolução N. 22.610/07. A função normativa é permitida, segundo o Ministro, ao TSE, porém exclusivamente e nos limites do texto legal: para a execução das leis eleitorais e do Código Eleitoral, que, como visto no inicio deste capítulo, nada dispõe sobre a perda de mandato eletivo por desfiliação partidária. Ademais, legislar primariamente sobre matéria eleitoral é função atribuída pela Constituição, em seu art. 121, à lei complementar, em conformidade com a denominada reserva de lei.

\subsubsection{O cumprimento pelo Legislativo da decisão da Justiça}

\section{Eleitoral de perda do mandato}

Afastadas as hipóteses de inconstitucionalidade, por previsão expressa da supramencionada Resolução N. 22.610/07 do TSE, uma vez decretada a perda do mandato pela Justiça Eleitoral, a decisão deve ser comunicada ao Presidente da Casa Legislativa para que este emposse o suplente no prazo de dez dias.

\footnotetext{
571 V. FERnANDo DiAs MENEZES DE Almeida, Considerações sobre a "regulação" no direito positivo brasileiro, in RDPE - Revista de Direito Público da Economia, n. 12 (out./dez. 2005); CHARLES EISENMANN, $O$ direito administrativo e o princípio da legalidade, RDA N. 56, abr-jun,1956, p.47 e ss.; ODETE MEDAUAR, $O$ Direito Administrativo em evolução, $2^{\text {a }}$. ed., São Paulo, Revista dos Tribunais, 2003; E. GRAU, $O$ direito posto e o direito pressuposto, cit., p. 244-254.
} 
Eventual recusa do Presidente da Câmara ou Assembléia Legislativa, agora diante do pronunciamento do STF e da edição de nova Resolução do TSE, entendese, em princípio, incabível. ${ }^{572}$ Além da força normativa das resoluções da Corte Eleitoral $^{573}$, assegura-se que a previsão do inciso $\mathrm{V}$ do art. $55 \mathrm{CF} / 88$ não abarca a "ampla defesa" consignada no parágrafo $3^{\circ}$. do mesmo artigo, uma vez que, no caso de decretação da perda do mandato pela Justiça Eleitoral por desfiliação partidária, as chances de defesa foram garantidas nessa Justiça, não se havendo de cogitar de nova instância de contraditório no Poder Legislativo. Há contudo, posições divergentes ${ }^{574}$, que entendem estar constitucionalmente garantidas a ampla defesa no Legislativo, ainda que já decidida a questão na Justiça Eleitoral, naturalmente nas esferas Federais e Estaduais, afastando a aplicação na esfera Parlamentar Municipal e no Executivo. E quanto à recusa do cumprimento da decisão pelo Presidente da Casa Legislativa, o entendimento é que apenas a imotivada omissão ou negação ensejaria ato de improbidade administrativa e crime de desobediência de ordem judicial. A motivação do Presidente da Câmara ou Assembleia estaria na inconstitucionalidade da Resolução N. 22.610/07 e na autonomia dos Poderes de recusar eficácia e execução a ato normativo que lhe pareça inconstitucional. A recusa da aplicação de ato inconstitucional por qualquer dos Poderes é entendimento pacífico das Cortes nacionais $^{575}$, bem como da doutrina. Encontramos, por exemplo, em A. DE MORAES, que os Poderes pautam suas condutas na estrita legalidade, primado do Estado de Direito Democrático, atentando às normas constitucionais. Assim, para o autor, o chefe do Poder, diante de ato flagrantemente inconstitucional, pode e deve "negar-se cumprimento, sem prejuízo de exame posterior pelo Judiciário" ${ }^{576}$. Em suma, existem duas posições diversas no que tange ao cumprimento da decisão da Justiça Eleitoral diante da perda do mandato por desfiliação partidária.

\footnotetext{
${ }^{572}$ Como visto na análise dos votos do STF sobre a fidelidade partidária, o então Presidente da Câmara dos Deputados, Arlindo Chinaglia, havia recusado declarar a vacância dos mandatos dos deputados que haviam migrado com base no pedido dos partidos que perderam suas cadeiras, fundados na Res. N. 22.526/07 do TSE. Um dos principais argumentos de Chinaglia, bem como dos litisconsortes, havia sido a inconstitucionalidade da indigitada Resolução não só pela ausência de seu caráter vinculante como pela exclusão da previsão da ampla defesa. Baseou-se ainda a negativa na jurisprudência da Corte Suprema até então vigente sobre a não incidência da perda do mandato por infidelidade partidária. STF, Pleno, MS 26.603-DF, rel. Min. Celso de Mello, 04.10.07, DJE 19.12.08.

${ }^{573}$ Art. 105 da Lei 9.504/97.

${ }^{574}$ V. T. T. CERQUEIRA, Fidelidade partidária e perda de mandato no Brasil: temas complexos, cit., p. 117 124.

${ }^{575}$ STF, Pleno, ADI N. 221/DF, rel. Min. Moreira Alves, DJ 22.10.93. Ficou consignado no v. acórdão que “os Poderes Executivo e Legislativo, por sua Chefia, podem tão só determinar aos seus órgãos subordinados que deixem de aplicar administrativamente as leis ou atos com força de lei que considerem inconstitucionais."

${ }^{576}$ A. DE MORAES, Direito Constitucional, cit., p. 702-3.
} 


\subsection{Os mecanismos apropriados para inclusão da fidelidade partidária no ordenamento jurídico}

Como já pontuado, o tema da migração partidária, um dos tópicos de uma ampla reforma política, não é de todo novo na discussão jurídica, assim como já habitou expressamente nosso ordenamento. Por não conter nenhum dispositivo que implique a perda do mandato no caso de infidelidade e, diante da indignação causada pelas inúmeras e frequentes trocas de partido, o Legislativo, em velocidade própria, movimentava-se em busca de uma solução para o enlace. Inicialmente, o assunto era tratado conjuntamente e com aspecto subsidiário no bloco das reformas político-eleitorais. Em meados dos anos noventa, maior relevância apresentavam as propostas de introdução da reeleição, a imposição de cláusula de barreira, a extinção das coligações proporcionais, regras sobre as eleições, estabelecimento do voto distrital misto, financiamento de campanhas, fixação de cotas de Vereadores por Município, entre outros ${ }^{577}$. Como visto, na década anterior, apenas a reeleição, por motivos claros, emplacou no rol das reformas políticas, deixando a tarefa mais árdua para os parlamentares do novo milênio.

Dentre as propostas de emenda à Carta constitucional, já se vislumbrava a intenção de se sancionar a infidelidade partidária com a perda do mandato. $\mathrm{O}$ ano de 2007 foi marcado por uma ampla discussão em torno do instituto da fidelização partidária, cujo reflexo, em termos parlamentares mostrou, na esteira da lição de M. HERMAN SALEM CAGgiano, uma "efervescente produção legislativa, buscando sancionar a atitude de infidelidade do parlamentar para com a sigla que concorreu para a conquista da vaga" ${ }^{278}$. A autora havia listado, à época de edição de sua obra em análise ${ }^{579}$, quarenta e três proposições legislativas então em curso, das quais três propostas de Emenda Constitucional (PEC) e seis projetos de lei haviam iniciado sua tramitação no Congresso. A jurista apontou, ainda, as PEC 41/96 e 166/96 como exemplos pretéritos que buscaram resolver a questão. Igualmente, a PEC 42-A, contemporânea às supracitadas (data de 1995 seu

\footnotetext{
577 M. Herman SAlem Caggiano identifica ao menos dez Projetos de Emenda à Constituição elaborados entre os anos de 1995 e 1996, que tratavam da reforma política. V. A fenomenologia dos trânsfugas no cenário político-eleitoral brasileiro, cit., p. 219.

${ }^{578}$ M. HeRMAn SALEM CAGGIANO, A fenomenologia dos trânsfugas no cenário político-eleitoral brasileiro, cit., p. 241.

${ }^{579}$ A primeira edição da obra de M. HeRMAN SALEM CAGGIANO, A fenomenologia dos trânsfugas no cenário político-eleitoral brasileiro, in $O$ voto das Américas, data de junho de 2008.
} 
projeto original), trazia em seu bojo semelhante intenção. Reeditada por diversas vezes, essa proposta reapareceu em 2007, redigida pelo Deputado Luciano Castro - líder do Partido da República - e cuja ementa previa:

"Altera os artigos 17, 45, 46 e 55 da Constituição Federal, determinando o fim da vinculação entre as candidaturas em âmbito nacional, estadual, distrital ou municipal, o fim das coligações partidárias proporcionais, voto de legenda, o fim da suplência para o cargo de Senador e o estabelecimento da fidelidade partidária."

Como se pode notar, a fidelidade aparece apenas como um dos tópicos, uma vez que a referida PEC procurou resgatar a reforma política, trazendo os seguintes temas: fim da verticalização, fim das coligações proporcionais, voto de legenda e o fim do suplente do cargo de Senador. Porém, nas alterações propostas no ano de 2007, a perda do mandato por desfiliação passa a ocupar majoritariamente a preocupação do legislador, fazendo-se inserir, no art. 17, que cuida dos partidos políticos, a expressa disposição de que a esses cabe a titularidade do mandato. Ampliou o rol de hipóteses de perda do mandato do art. 55, inserindo a desfiliação como causa de perda do mandato, estabelecendo as exceções de praxe, tal como previstas pela regulamentação da Corte Eleitoral ${ }^{580}$, acrescentando, ademais, um período permissivo às trocas de agremiação, que se contaria a partir da fase de convenções partidárias prévias aos pleitos eleitorais. ${ }^{581}$

Interessante observar que a justificação do referido projeto deixa transparecer todo embate entre Poderes que se exacerbou no ano de 2007, fruto do ativismo judicial que decidiu sobre a questão da fidelidade em sua total extensão. $\mathrm{O}$ texto se assemelha a um verdadeiro manifesto, buscando reafirmar a função e independência do Legislativo:

"Ultimamente, o Congresso Nacional tem permitido que outros Poderes da República usurpem de suas atribuições, causando assim grande confusão jurídico-institucional em nosso País.

As últimas manifestações da Justiça Eleitoral e do Supremo Tribunal Federal forçam o Parlamento Brasileiro a resgatar suas competências Constitucionais, firmando assim os parâmetros necessários para as eleições no Brasil.

${ }^{580}$ TSE, Res. N. 22.610, rel. Min. Cezar Peluso, 25.10.07, DJ 30.10.07.

581 Art. $4^{\circ} .$. "Dê-se ao art. 55 da Constituição Federal a seguinte redação: 'art.55 (...) VII - que incorrer em infidelidade partidária. (...) $\S 5^{\circ}$. Pratica ato de infidelidade partidária quem, fora do período delimitado por esta Constituição, muda de partido pelo qual foi eleito, salvo em caso de incorporação ou fusão do partido, criação de novo partido, mudança substancial ou desvio reiterado do programa partidário ou grave discriminação pessoal. $\S 6^{\circ}$. Será admitida a mudança de partido, aos detentores de cargo eletivo, sem perda do mandato, no período da realização das convenções partidárias anteriores à eleição subsequente, visando a concorrer à eleição na mesma circunscrição."” 
É função do Congresso Nacional estabelecer os ordenamentos, os limites e as balizas para as eleições, em todos os níveis, competência esta que jamais abdicaremos.",582

Por sua vez, a PEC 04-2007 $7^{583}$, de autoria do Deputado Flavio Dino do PC do B do Maranhão, propôs apenas alterar o art. 55, incluindo igualmente a infidelidade como hipótese de perda do mandato em um de seus incisos. Em seu parágrafo segundo, acrescentava as exceções padrão ${ }^{584}$, repetindo as regras do TSE para permissão de mudança de legenda. Elemento novel foi a criação da então denominada pelos meios de comunicação de "janela da infidelidade". Trata-se de um período em que as trocas seriam livremente permitidas e assim seriam reguladas:

“§ $3^{\circ}$ Será admitida a mudança de partido, sem perda do mandato, no período de 30 (trinta) dias imediatamente anterior ao término do prazo de filiação partidária para candidatura à eleição subsequente.",585

Em termos de procedimento, buscou-se alterar a atual previsão, de forma sutil, mas significativa. Para as hipóteses de perda dos incisos I e II do art. 55 (infração às proibições e quebra de decoro) ${ }^{586}$ estabelecia a competência do Congresso Nacional, pela respectiva casa, para decidir pela punição, todavia, não mais pelo voto secreto para se deliberar acerca da perda do mandato, que seria suprimido nessa nova redação. Para as hipóteses dos incisos III e IV (ausência reiterada e perda/suspensão dos direitos políticos) previa a declaração da perda pela Mesa da Casa respectiva, de ofício ou por provocação, tal como na redação original ${ }^{587}$. E, por fim, para os incisos realocados - V e VI - uma alteração no procedimento. Previa, de forma semelhante à vigente, a competência da Mesa da Casa respectiva para declarar a perda. Porém, exigir-se-ia, desta feita, o trânsito em julgado da decisão emitida pela Justiça Eleitoral (em alteração à previsão vigente do inciso $\mathrm{V}$, art. 55, CF, que não requer o trânsito em julgado da decisão). Além disso, acresceria os

582 PEC N. 42/2007, Dep. Luciano Castro.

583 Em justificativa à sua proposição, colocava-se a implementação das regras de infidelidade como pressupostos para uma reforma política mais profunda, mormente ao estabelecimento do voto em "lista fechada" e ao financiamento público de campanhas.

584 Conforme texto da citada PEC, "abriram-se três exceções à regra: o direito de o parlamentar, discordando sistematicamente da orientação partidária, participar da criação de um novo partido político; ou mudar de legenda, quando a 'infidelidade' provier do partido, à vista de mudanças essenciais nos programas e estatutos formalmente registrados". As exceções se destinam a "evitar o risco de formação de ditaduras partidárias", segundo o relator. A mesma justificativa se aplicaria à criação de uma janela permissiva às trocas, em momento anterior à data limite para filiação, que se dá um ano antes das eleições. Previsão, como visto, diversa da proposta pela PEC-42-A.

${ }_{585}^{58 C}$ PE4-2007, Dep. Flavio Dino.

${ }^{586}$ Suprimir-se-ia desta competência e deste procedimento, portanto, o inciso VI (condenação criminal), que passaria a ter nova previsão procedimental.

${ }^{587}$ Suprimindo, portanto, o inciso V (decreto da Justiça Eleitoral) do procedimento atualmente vigente por força do $\S 3^{\circ}$. art. 55, CF/88. 
procedimentos para decisão da perda de mandato por infidelidade, atribuindo a competência ao TSE nos casos de Senadores e Deputados Federais e aos Tribunais Regionais Eleitorais ${ }^{588}$ nos demais cargos eletivos parlamentares, olvidando-se de mencionar, aliás, os cargos eletivos do Poder Executivo. De resto, manteve a vigente impossibilidade da renúncia como forma de livrar-se da punição de perda do mandato.

Às vésperas da edição da Resolução N. 22.610/07 pelo TSE - e poucos dias após a decisão do STF sobre a fidelidade - o então Presidente interino do Senado, Tião Viana, redigiu a PEC 182 de 22 de outubro de 2007. Ao contrário das demais propostas, esta previa tão somente a perda do mandato por infidelidade, tendo inclusive como exceções apenas a extinção, fusão ou incorporação de partidos, nada prevendo a respeito de mudança programática dos partidos ou perseguição política. No entanto, estenderia a punição a todos os cargos eletivos do Executivo, atribuindo, igualmente, à Justiça Eleitoral, a competência para o julgamento.

De autoria do Deputado Federal Wilson Santiago e outros, a PEC 124/07 era bem mais ousada. Primeiro pela proposta de alteração no sistema proporcional para o sistema majoritário para a eleição de Deputados Federais, Estaduais e Vereadores. Justificar-se-ia em prol da estabilidade da representatividade eleitoral e da governabilidade, por meio da "constituição das circunscrições eleitorais em instâncias distritais onde a maioria elegeria os candidatos, independentemente dos partidos pelo qual concorram." De outro lado, criaria uma larga "janela da fidelidade". Ou seja, ao invés de permitir o trocatroca em um curto período, faria o oposto: a fidelidade somente seria exigida por um ano após as eleições e após a filiação (cuja data limite se observa um ano antes das eleições). Para o restante do mandato (sua maior parcela, diga-se, de passagem), a infidelidade estaria liberada. Tal proposta causa no mínimo a sensação de que as raposas estão a tomar conta do galinheiro, na medida em que, por um simples subterfúgio, praticamente anularia toda construção de exigência de fidelidade feita pelas Cortes, bem como da atribuição do mandato ao partido político. E pior: far-se-ia tudo isso sob a bandeira da fidelidade e da moralização ${ }^{589}$.

\footnotetext{
${ }^{588}$ De acordo com a relatoria da PEC 04-2007, "Optou-se por submeter a controvérsia ao crivo da Justiça Eleitoral, que assegurará ampla defesa e dirá quanto à configuração da quebra da fidelidade, sem que haja justo motivo, impondo a sanção de perda do mandato. A opção decorre, além da competência específica, do fato de ser a Justiça Eleitoral quem registra os programas e estatutos partidários, bem como suas alterações." ${ }^{589}$ Nesse sentido, vale a pena observar a justificação apresentada na indigitada PEC: "A filiação partidária deve ocorrer de acordo com as convicções do candidato para que possa representar uma proposta programática que o respalde frente aos eleitores. Assim, a filiação partidária é o requisito que agrega o político a um ideário e a um grupo de pares que defendem um mesmo posicionamento ideológico. A Constituição Federal é clara quando estabelece o critério de filiação partidária como condição para a
} 
Apesar das diversas propostas apresentadas, em destaque aparece a proposta de Emenda à Constituição elaborada pelo Senador Marco Maciel. A PEC-23, de fevereiro de 2007, propunha a alteração dos arts. 17 e 55 da Constituição e sua entrada em vigor estava prevista em janeiro de 2010 (em respeito à anterioridade e liberando as eleições municipais de 2008 que se aproximavam). Objetivava estabelecer a perda do mandato para os infiéis, resguardadas as devidas exceções. A sanção passaria a constar do rol fechado do art. 55, obtendo nível constitucional, confrontando-se, todavia, com a natureza do mandato representativo - mandato livre decorrente da representação popular ditado pelo art. 45 da Carta Magna, conforme explanado nesse capítulo. Conforme relembra M. HERMAN SALEM CAGGIANO ${ }^{590}$, tal proposta recupera a técnica da Constituição anterior em relação à fidelidade, empregando como fórmula a obstacularizar a migração partidária desmotivada a retenção da vaga pelo partido em detrimento ao parlamentar, que perde o mandato.

Em contraponto às PECs, proliferaram inúmeros projetos de lei, tanto de classe ordinária quanto complementar, com diferentes mecanismos para penalizar a migração entre partidos. De um lado, o projeto de Lei de autoria do Deputado Luciano Castro (PL 35/07), visava alterar a Lei das Inelegibilidades (que tem natureza de lei complementar) e o Código Eleitoral. A proposta incorporou diversas emendas substitutivas, gerando nova versão - o PL 58/07. Sua principal fórmula consistia na inclusão de uma nova hipótese de inelegibilidade, adicionando uma nova alínea ao inciso I do art. $1^{\circ}$., da Lei 64/90, propondo tornarem-se ilegíveis:

"Os membros do Congresso Nacional, das Assembléias Legislativas, da Câmara Legislativa, das Câmaras Municipais, o Presidente e o Vice-Presidente da República, o Governador e o Vice-Governador de Estado e do Distrito Federal, o Prefeito e o VicePrefeito, que tenham alterado a sua filiação partidária ${ }^{591}$ fora do período de 30 (trinta)

elegibilidade. O texto constitucional deve, por razões disciplinares mais rígidas, estabelecer o prazo mínimo em que o candidato necessita figurar no partido pelo qual pretende se eleger. Também precisa delimitar o mínimo de tempo em que o eleito deve permanecer no partido político que o elegeu, como forma de prestigiar a tradição republicana brasileira e zelar pela necessária compatibilidade das ideias que defende no marco da institucionalidade doutrinária. É necessário limitar o oportunismo individualista do qual sai vencedor aquele que, aproveitando-se de uma filiação partidária efetuada aleatoriamente no apagar das luzes, impõe-se pelo poder econômico, em vez de fazê-lo pelo seu ideário programático. Este é o motivo por que esta Proposta de Emenda Constitucional estabelece o prazo mínimo de 1 (um) ano antes das eleições para a filiação partidária do candidato, esta é a razão pela qual propõe o estabelecimento de, no mínimo, 1 (um) ano de mandato para que o ocupante do cargo político eletivo possa mudar de partido. Assim, no mínimo, um ano antes das eleições, a candidatura pertence ao partido; um ano depois das eleições, o mandato será do partido político." PEC 124/07, Dep. Wilson Santiago et alli, disponível (on line) in www. camara.gov.br., [01.05.09].

${ }^{590}$ M. HeRmAn SAlEM CAGGIANO, A fenomenologia dos trânsfugas no cenário político-eleitoral brasileiro, cit., p. 245 e ss.

${ }^{591}$ Da proposta original do PL 35/07, já em sua reedição via PL 35-B/07, fora excluído o trecho "que tenham alterado sua filiação partidária nos termos do artigo $9^{\circ}$. da Lei 9.504, de 30 de setembro de 1997, (...)”. O 
dias imediatamente anterior ao término do prazo de filiação que possibilite a candidatura, para os 4 (quatro) anos subsequentes ao término de seus respectivos mandatos." 592

Note-se que tal construção já previa a criação de um intervalo para as trocas de partido sem punição, desde sua redação original, mostrando que a colocação de uma válvula de escape para as trocas partidárias não era ideia nova na classe parlamentar.

Relativamente às exceções à punição, além daquelas de praxe (criação de novo partido político; descumprimento pelo partido do programa ou estatuto; perseguição política interna), o mencionado projeto de lei deixaria de apenar também: a filiação que visasse a eleição na mesma circunscrição, nos trinta dias anteriores ao prazo de filiação, e; a renúncia do mandato ${ }^{593}$.

No tocante à legitimidade do pedido, atribui tão somente aos partidos, não havendo disposição que permita, ainda que subsidiariamente, ao Ministério Público ou ao suplente, requerer a punição ao parlamentar trânsfuga. O prazo para proposta e resposta seria de quinze dias ${ }^{594}$.

Essa proposta de reedição da LC 64/90, procurava também assegurar a aplicação não retroativa do dispositivo. Para tanto, previa que ficariam "resguardadas e convalidadas todas as mudanças de filiação partidária constituídas até a data de 30 de setembro de 2007, não incidindo nenhuma restrição de direito ou sanção."

Arranhando a competência do TSE, propunha, ainda, alteração no art. 23 do Código Eleitoral, buscando impedir a retroatividade jurisprudencial, conforme se vislumbra no texto sugerido:

“Art. 23 [...] inciso XII - responder, sobre matéria eleitoral, às consultas que lhe forem feitas em tese por órgão nacional de partido político, vedada a aplicação retroativa da nova interpretação daí derivada [...]." 595 (grifos nossos)

Em suma, tal propositura, valendo-se de lei complementar, traz a infidelidade como nova hipótese de inelegibilidade, além de punir com a perda do mandato

citado artigo contém a previsão da anterioridade anual para filiação visando concorrer às eleições seguintes. (os grifos, nossos, representam o excerto excluído).

592 PL N. 58/07, Deputado Luciano Castro, disponível (on line) in www. camara.gov.br., [01.05.09].

${ }^{593}$ É certo que o texto constitucional vigente - art. 55, § $4^{\circ}$. - prevê a suspensão dos efeitos da renúncia quanto à perda do mandato. O que o PL 58/07 propôs foi a eliminação dos efeitos da inelegibilidade diante da renúncia.

${ }^{594}$ Em comparação com a Res. N.22.610/07- TSE, a legitimidade para se requerer a perda do mandato foi dada aos partidos políticos, que deveriam exercer tal direito no prazo de trinta dias, após os quais, legitimados estariam o suplente e o Parquet, em igual prazo, para propor a ação objetivando a decretação de perda do mandato pela Justiça Eleitoral.

595 PL N. 58/07, Deputado Luciano Castro, disponível (on line) in www. camara.gov.br., [01.05.09]. 
a ser decretada pela Justiça Eleitoral, abrindo igualmente uma "janela para a infidelidade" e diversas válvulas de escape à punição.

De outro lado, concorrendo com o PL 58/07, um sem número de projetos de lei de ambas as naturezas - complementar e ordinária - traziam ora disposições semelhantes a este ${ }^{596}$, ora inovavam em sua proposta. Cite-se como exemplo o PL 124 de outubro de 2007, de autoria do Deputado Flavio Dino. Tal projeto regula da mesma forma que a Resolução N. 22.610/07 do TSE o procedimento de decretação de perda do mandato e de justificação para abandono de legenda. Dispõe sobre a arguição de infidelidade partidária e sobre a justificação para desfiliação partidária, por meio de uma adaptação dos trâmites contidos nos arts. $3^{\circ}$ a $7^{\circ}$ da Lei Complementar $n^{\circ}$ 64, de 18 de maio de 1990, que regulam a ação de impugnação de pedido de registro. $\mathrm{O}$ procedimento sugerido busca assegurar aos acusados ampla dilação probatória, que permitirá a avaliação da presença de circunstância excludente da decretação de perda do mandato, legitimando a troca de legenda, quando configuradas quaisquer das hipóteses que a autorizam. Este projeto de lei nada dispõe sobre a criação de nova inelegibilidade.

Outro projeto de lei, de N. 1.723, também de autoria do Deputado Flavio Dino, dispõe sobre a interpretação, as consequências e os efeitos das mudanças de filiação partidária. Traz como distinção um novo período permissivo às trocas, anulando o marco inicial proposto pelas Cortes, ao prever: "Ficam resguardadas todas as mudanças de filiação partidária constituídas até o termo final do prazo para filiações visando à participação nas eleições municipais de 2008 " 597 . Propõe também alteração no inciso XII do art. 23 do Código Eleitoral, cuja nova redação se assemelha à do PL 58/07, repetindo a vedação à aplicação de nova interpretação pela Justiça.

Já o PL 1.336/07, de 14 de junho de 2007 - portanto anterior ao pronunciamento do STF - igualmente de autoria do Deputado Luciano Castro, contemporiza a punição por infidelidade e exclui a possibilidade de perda do mandato,

\footnotetext{
${ }^{596}$ A exemplo, cf. o PL 119/07 do Vice-Líder da Bancada do PDT/RS. Vale mencionar, a título ilustrativo, o PL 4433/2004, de autoria da Deputada juíza Denise Frossard, que, por meio de alteração na Lei 9.096/95, pretendia adicionar um parágrafo ao art. 24, dizendo: "Parágrafo único. Todo aquele que estiver no exercício efetivo da presidência de Casa Legislativa, fica dispensado do dever de fidelidade partidária e livre de qualquer subordinação ao seu partido, enquanto permanecer no cargo." A justificativa para o projeto fundava-se na necessidade de independência do presidente da Casa Legislativa no exercício de sua função em relação ao dever de fidelidade ao partido. Visava-se, então, superar quaisquer limitações de fidelidade incorporadas nos estatutos partidários. Note-se que em 2004 não existia ainda maiores tentativas de fazer prevalecer a fidelidade partidária no ordenamento. Foi no ano de 2007, por ocasião do intenso debate iniciado no TSE e por sua decisão criadora de normas, que proliferaram inúmeros projetos de lei intencionando regular a questão da fidelidade partidária. PL 119/07, Deputado Pompeo de Mattos, e PL 4433/2004, Deputada Denise Frossard, disponíveis (on line) in www. camara.gov.br., [01.05.09].

${ }^{597}$ PL N. 1.723/07, Deputado Flavio Dino, disponível (on line) in www. camara.gov.br., [01.05.09].
} 
colocando, ao invés, a inelegibilidade como sanção. Estabelece o dever de fidelidade por três anos após a diplomação e reduz o prazo para filiação para seis meses, após o qual, não será mais permitido mudar de sigla. Porém, a pena para o infiel não é a perda do mandato, mas tornar-se inelegível. O que de fato pode soar mais conveniente à classe parlamentar, uma vez que não sanciona com a perda do mandato em exercício, mas penaliza para uma próxima legislatura, quando não há certeza que o eleito volte a ser escolhido pelo povo.

A justificativa construída para efetuar, no projeto em tela, a mudança proposta na decisão do Supremo Tribunal, apesar de reconhecer a importância da fidelização, retoma os argumentos divergentes da corrente majoritária recentemente formada em nossas Cortes. Assim, justifica-se o referido projeto de lei:

“[...] sendo clara a necessidade em se prever uma fidelização do eleito ao partido pelo qual foi consagrado nas urnas, mas em contrapartida a isso, resguardar o mandato e suas prerrogativas, não devendo a sanção para a infidelidade partidária, acarretar em eventual perda de mandato, o que de forma incontestável iria contrariar nossa Constituição, uma vez que decorrente de todo processo eleitoral em nosso País, o cidadão hoje, ainda que pese toda a estrutura partidária, vota na verdade no candidato e não na legenda.

É clara a relação simbiótica existente entre o eleito e o partido. Na proporção em que o eleito depende da legenda, a legenda não existiria sem o eleito, prova disso inclusive é a questão do tempo eleitoral a que o partido político tem direito em face do número de representantes eleitos.

Logo não há que se falar em sanção de perda de mandato, até porque a prerrogativa para isso é de nossa Carta Magna. Assim, nesse sentido e com vistas a resguardar as legendas e instituir o instrumento da "fidelização", temos que em conformidade com nosso ordenamento jurídico vigente o mais coerente é prever a sanção de inelegibilidade ao candidato que não observar o tempo mínimo de filiação ao partido." ${ }^{598}$ (grifos nossos)

Novamente pode-se perceber que os argumentos que giram em torno da questão da fidelidade partidária podem ser aplicados para justificar diversas e divergentes posições. Construiu-se um cenário onde "tudo cabe, tudo é viável”. Mais do que isso, é possível manobrar-se o grau de rigidez do instituto da fidelidade e a forma de sua verificação, seja via interpretação jurídica, seja via edição de novas normas. Como visto, há posições que defendem a fidelidade, mas atribuem ao seu desrespeito diferentes sanções, que acabam por atenuar o ato de migração. Vide o exemplo da "janela da infidelidade" ou então o acima exposto da "troca" da sanção de perda do mandato pela sanção futura da inelegibilidade.

Outra conclusão que se extrai da diversidade de propostas, tanto na forma adotada quanto em seus conteúdos é uma sensação de insuficiência do debate político parlamentar e a consequente incapacidade de formatar acordos políticos que viabilizassem

${ }^{598}$ PL N. 1.336/07, Deputado Luciano Castro, disponível (on line) in www. camara.gov.br., [01.05.09]. 
a votação de quaisquer desses projetos. Quanto mais elementos e mudanças se acresceram às propostas, visando uma ampla reforma política, mais parecia dificultosa a tarefa de fazêlas fluírem, de modo a culminar com a efetiva alteração no ordenamento. A riqueza criativa de alternativas e fórmulas para atingir o resultado almejado parece ter prejudicado a tramitação no Legislativo. Nesse sentido, as proposituras que buscaram regular o instituto da fidelidade soaram ter mais chances de aprovação.

Não obstante, completados dois anos da decisão emblemática do STF, não logrou sucesso nenhuma das propostas existentes, de modo que pesa ainda sobre o Legislativo a pecha de inatividade, a ceder espaço para atuação das Cortes judiciárias.

Diante das principais propostas, todavia, é necessário atentar para o fato de que a "lei complementar não se afigura veículo adequado para alterar a configuração da natureza do mandato representativo" ${ }^{599}$, obra cabível tão somente ao poder constituinte. Deve-se respeitar o status constitucional em que é colocada a representação política e preservar a tutela dos princípios constitucionais de participação política, livre associação, livre manifestação e exteriorização do pensamento, que, em um proclamado Estado Democrático de Direito, não podem ser reduzidos, senão pelas formas previstas no ordenamento, sob pena de grave atentado à segurança jurídica e à sua unidade. Enfim, qualquer tentativa de moralização do exercício do mandato, encontraria respaldo no ordenamento apenas pela proposta reformadora da Emenda Constitucional e não via ato normativo infraconstitucional. Muito menos, via ato normativo secundário da Justiça Eleitoral, que determinou restrições às trocas de mandato por meio da edição de resoluções.

Nunca é demais lembrar que a democracia tem nas eleições um instrumento sensível e necessário para o pleno exercício da soberania popular. Um Estado Democrático de Direito, propõe-se a proteger seus institutos democráticos, estabelecendo um regime jurídico de alçada constitucional para garantir os resultados que refletem a vontade geral. Além dos dispositivos expressamente consignados na Carta Maior, um arcabouço principiológico resguarda o processo democrático, buscando a estabilidade eleitoral e a garantia dos direitos fundamentais. A existência de mecanismos de garantias desses direitos e aplicação desses princípios é que forma o modelo democrático do Estado de Direito, assegurando credibilidade, políticas públicas efetivas e definidas e estabilidade do governo.

\footnotetext{
${ }^{599}$ M. HeRman SAlem CagGiano, A fenomenologia dos trânsfugas no cenário político-eleitoral brasileiro,
} cit., p. 248. 


\subsection{A perda de mandato por infidelidade após o marco regulatório}

Ao fixar data passada como marco da penalização pela desfiliação partidária, o STF livrou um bom número de trânsfugas da perda de seus mandatos, pois a grande maioria havia trocado de legenda em momento anterior à resposta do TSE à Consulta N. 1.398. Houvesse a decisão dos Tribunais optado por retroagir ao início da legislatura - tal como pretendiam os Ministros Carlos Britto e Marco Aurélio - uma significativa parcela da classe parlamentar estaria sujeita ao processo de decretação da perda de seus respectivos mandatos na Justiça Eleitoral.

Não obstante, conforme exposto no voto do Ministro Gilmar Mendes nos mandados supracitados, não foram poucos os Deputados a trocar de legenda após o dia 27 de março de 2007. A primeira da lista foi a deputada Jusmari Oliveira - como se pode observar no quadro a seguir. Sua desfiliação, dois dias após a data limite estabelecida, implicou a concessão parcial da segurança pela Ministra Cármen Lúcia no MS 26.604. 
Quadro 4 : “ Trocas partidárias após a data limite $(27 / 03 / 2007)^{600}$

\begin{tabular}{|c|c|c|}
\hline Data da troca & Deputado (Estado) & Partido Origem - Novo Partido \\
\hline $27 / 09 / 07$ & CARLOS SOUZA (AM) & PP - PRB \\
\hline $25 / 09 / 07$ & CLODOVIL HERNANDES (SP) & PTC - PR \\
\hline $24 / 09 / 07$ & SÉRGIO BRITTO (BA) & PDT - PMDB \\
\hline $21 / 09 / 07$ & DAVI ALVES SILVA (MA) & PDT - PSC \\
\hline $12 / 09 / 07$ & DR. PAULO CESAR (RJ) & PTB - PR \\
\hline $21 / 08 / 07$ & GERVÁSIO SILVA (SC) & DEM - PSDB \\
\hline $07 / 08 / 07$ & GERALDO REZENDE (MS) & PPS - PMDB \\
\hline $12 / 07 / 07$ & JURANDY LOUREIRO (ES) & PTB - PSC \\
\hline $11 / 07 / 07$ & TAKAYANA (PR) & PTB - PSC \\
\hline $05 / 07 / 07$ & CLEBER VERDE (MA) & PTB - PRB \\
\hline $04 / 07 / 07$ & MARCOS ANTONIO (PE) & PTB - PSC \\
\hline $03 / 07 / 07$ & SILAS CÂMERA (AM) & S.PART.-PDT \\
\hline $28 / 06 / 07$ & DAMIÃO FELICIANO (PB) & PAN - S.PART \\
\hline $04 / 06 / 07$ & MARCOS ANTONIO (PE) & PTB - PMDB \\
\hline $02 / 05 / 07$ & JACKSON BARRETO (SE) & PR - PV \\
\hline $25 / 04 / 07$ & LINDOMAR GARÇON (RO) & PFL - PR \\
\hline $02 / 04 / 07$ & JUSMARI OLIVEIRA (BA) & \\
\hline
\end{tabular}

Quadro 5: A dança das cadeiras na atual legislatura ${ }^{601}$

\begin{tabular}{|c|c|c|c|c|c|}
\hline Partido & $\begin{array}{c}\text { Cadeiras em } \\
\text { out/09 }\end{array}$ & $\begin{array}{c}\text { Cadeiras na } \\
\text { data da posse }\end{array}$ & Partido & $\begin{array}{c}\text { Cadeiras em } \\
\text { out/09 }\end{array}$ & $\begin{array}{c}\text { Cadeiras na } \\
\text { data da posse }\end{array}$ \\
\hline PMDB/PTC & 93 & 93 & PTB & 22 & 21 \\
\hline PT & 78 & 83 & PSC & 15 & 7 \\
\hline DEM & 57 & 62 & PV & 14 & 13 \\
\hline PSDB & 57 & 64 & PPS & 13 & 17 \\
\hline $\begin{array}{c}\text { PSB/PCdoB/ } \\
\text { PMN/PRB }\end{array}$ & 51 & 45 & Psol & 3 & 3 \\
\hline PR & 45 & 34 & PHS & 2 & 2 \\
\hline PP & 38 & 41 & PT do B & 1 & 1 \\
\hline PDT & 23 & 23 & Total & $512^{(*)}$ & 513 \\
\hline
\end{tabular}

Como era de se esperar, uma chuva de pedidos viria a cair sobre os tribunais eleitorais, sendo certo que o número de Vereadores e Deputados Estaduais migrantes superaria o de Deputados Federais por mera questão estatística.

\footnotetext{
${ }^{600}$ Fonte: STF, Pleno, MS 26.603-DF, rel. Min. Celso de Mello, 04.10.07, DJE 19.12.08.

${ }^{601}$ Composição das bancadas em 10 de outubro de 2009. Secretaria Geral da Mesa da Câmara dos Deputados - SGM, disponível (on line) in www2.camara.gov.br., [22.10.09]. Nota: (*) Eliseu Moura (PP-MA) foi convocado, mas não havia assumido o cargo até a data do levantamento.
} 
Findo em 29 de novembro de 2007 o prazo para apresentação por parte dos partidos políticos dos pedidos de decretação da perda de mandato por desfiliação daqueles que haviam migrado anteriormente à decisão do STF em estudo, a Justiça Eleitoral divulgou, no dia seguinte, que, após menos de dois meses da decisão do STF acerca do assunto, 1.773 pedidos visando recuperar os mandatos eletivos daqueles que migraram haviam sido efetivados perante os Tribunais eleitorais. De acordo com o TSE ${ }^{602}$, foram computados dados de 18 dos 26 estados, sendo que o TRE-SP recebeu o maior número de pedidos: 304 .

À época, delineava-se o seguinte quadro: no Congresso Nacional quatro eram os partidos a solicitar a devolução das cadeiras parlamentares, a saber: DEM, PT, PPS e PTC. Seis Deputados Federais e um Senador desta lista haviam migrado após a data limite estabelecida pelo $\mathrm{STF}^{603}$.

Todavia, para surpresa de muitos à época, a decisão do TSE que estabeleceu a perda do mandato por desfiliação, completou um ano de vigência - ao final de março de 2008 - sem que nenhum Deputado, Federal ou Estadual, perdesse seu mandato, apesar de vários destes estarem sujeitos aos efeitos da decisão. De outra face, cento e onze Vereadores, contudo, foram alvo da institucionalização da fidelidade partidária $^{604}$. O primeiro político a perder o mandato eletivo após a decisão do STF, de que se tem notícia, foi o Vereador Lourival Pereira de Oliveira, do Município de Buritis, em

${ }^{602}$ Com razão, o TSE identificou que grande parte dos pedidos sofreriam da ausência de legitimidade pois apresentados por suplentes no prazo reservado pela Res. N. 22.610 para requerimento dos partidos políticos. De acordo com essa norma, os demais juridicamente interessados (os suplentes e o MPE) poderiam entrar com o pedido apenas subsidiariamente, na omissão do partido interessado, o que somente se atestaria transcorrido o prazo inicial de trinta dias. De fato, em 30 de novembro de 2007 iniciava-se a contagem de prazo de 30 dias para os demais interessados e o Parquet proporem a ação, no melhor entendimento da citada Resolução. TSE, Res. N. 22.610, rel. Min. Cezar Peluso, 25.10.07, DJ 30.10.07.

${ }^{603}$ O DEM requerera os mandatos da deputada Jusmari Oliveira (PR-BA) - objeto da decisão no MS 26.604DF no STF- e dos deputados Gervásio Silva (PSDB-SC) e Walter Brito Neto (PRB-PB), além do senador Edison Lobão (PMDB-MA). Por sua vez o PT solicitou a vaga do deputado Paulo Rubem Santiago Ferreira (PDT-PE). O PTC representou contra o deputado migrante Clodovil Hernandes (PR-SP) e o PPS contra o deputado Geraldo Resende (PMDB-MS).

${ }^{604} \mathrm{O}$ presidente da União dos Vereadores do Brasil se manifestou contra a decisão do STF ao determinar uma data retroativa para a instituição da fidelidade, pois "não deu oportunidade para que os políticos tivessem a oportunidade de se adequar à nova legislação". Portal Aprendiz, Em um ano de fidelidade partidária, 111 são cassados em todo o país, 26.03.08, disponível (on line) in http://aprendiz.uol.com.br/ content/neuugogoui.mmp., [20.07.09]. Como oportunamente comentado, a retroatividade dos efeitos da decisão como modulação afetou certamente a segurança jurídica, não por impedir que os políticos "se adaptassem" aos novos tempos, mas sim, pela alteração das "regras do jogo" no meio do campeonato. Devese ressaltar também que o número absoluto de Vereadores no país é cerca de cinquenta vezes maior que o de Deputados Federais e quase cem vezes maior do que o de Deputados Federais. Disso resulta que o esforço que um partido faz para impedir perder uma cadeira na Câmara dos Deputados é significativamente maior que quando se depara com a perda de uma vaga em uma Assembléia Estadual. Já a proporção de Vereadores que perderam o seu mandato é ínfima (aproximadamente 0,2\%). Não se observou esforço partidário para impedir essa centena de cassações. Tal proporção sobreposta à totalidade dos 513 Deputados Federais, significaria a perda de apenas uma cadeira parlamentar federal. 
Rondônia. Eleito pelo PSDB, filiou-se posteriormente ao PPS, retornou ao PSDB e migrou novamente para o PV. A decisão havia sido confirmada em 17 de dezembro de 2007, porém o processo foi anulado pela Justiça Eleitoral posteriormente em janeiro de 2008, atendendo a um pedido de reconsideração que provocou o reconhecimento de falha processual consistente na ausência de patrono na propositura da ação, implicando falta de capacidade postulatória, bem como erro na qualificação do autor. ${ }^{605}$

Diversos foram os Tribunais Regionais a decretar a perda do mandato por infidelidade, sendo notória a divergência apresentada pelo TRE da Bahia, que entendeu ser inconstitucional a Resolução do TSE. No entendimento de seu vice-presidente, Carlos Alberto Cintra, o TRE da Bahia não se opôs ao TSE. Declarou que "apenas arguimos com base no artigo 121 da Constituição Federal a competência das Cortes - superior e regionais - no que se refere ao julgamento dos processos de infidelidade partidária"606.

Às vésperas do fechamento desta dissertação, a mídia estampava em suas manchetes: "Regra da fidelidade fracassa" ${ }^{607}$. Até um dia antes do prazo final para filiação às legendas que concorrerão as eleições gerais de 2010, nada menos que quarenta e cinco Deputados Federais, Senadores e detentores de cargos eletivos trocaram de agremiação partidária, ignorando a sanção imposta pelo Judiciário em 2007. Com a proximidade das eleições, notou-se um movimento de migração para o partido que possui (nos últimos meses de 2009) o candidato mais bem cotado nas pesquisas de opinião - o PSDB, de José Serra, partido de oposição ao governo. O fato corrobora o anteriormente exposto, mostrando que as estratégias de mudança de legenda giram em torno da busca por maiores chances na carreira política, o que ocorre quando se está ao lado do partido vencedor das eleições $^{608}$. Além desses motivos, outros fatores explicam a afronta à regra da fidelidade. Primeiramente, ainda que se submetessem ao longo processo de decretação de perda do mandato por desfiliação partidária, quando transitada em julgado a decisão, pouco ou nada restaria do mandato na legislatura que se finda em fevereiro de 2011. Em segundo lugar, observou-se que os grandes partidos, como o PT e o PMDB tem abdicado de reivindicar

\footnotetext{
${ }^{605} \mathrm{G} 1$, Justiça anula processo que cassou $1^{\circ}$ mandato por infidelidade partidária, 23.01.08, disponível (on line) in http://g1.globo.com/Noticias/Politica/0,MUL271049-5601,00-justica+anula+processo+que+cassou+ mandato+por+infidelidade+partidaria.html., [20.07.09].

${ }^{606}$ Portal Aprendiz, Em um ano de fidelidade partidária, 111 são cassados em todo o país, cit.

${ }^{607}$ Folha on line, Regra de fidelidade fracassa, e 45 políticos trocam de partido, 02.10.09, disponível (on line) in www.uj.com.br/online/noticias., [04.10.09].

${ }^{608}$ Conforme constatou C. RANULFO MELO, as trocas partidárias se intensificam no primeiro e no terceiro ano das legislaturas. No início, a movimentação se dá em direção à base governista. No terceiro ano, posiciona-se para definir o futuro na reeleição parlamentar. Cf. Retirando as cadeiras do lugar, cit., p.161-171.
} 
suas vagas na Justiça Eleitoral ${ }^{609}$. Por fim, dos dezoito parlamentares Federais julgados pelo TSE ${ }^{610}$, apenas o Deputado Walter Correia de Brito Neto efetivamente perdeu seu mandato para o DEM.

Note-se que penoso foi o processo para retirar a cadeira parlamentar de Brito Neto. Tendo o TSE decretado unanimimente a perda de mandato eletivo por desfiliação partidária sem justa causa em acórdão publicado em 5 de maio de $2008^{611}$, inúmeros recursos foram interpostos pelo Deputado, até que, em 16 de dezembro do mesmo ano, a Segunda Turma do Supremo Tribunal Federal, por votação também unânime, determinou a imediata execução dos acórdãos emanados pelo TSE. Na mesma data, o TSE ordenou a intimação pessoal do Presidente da Câmara dos Deputados, para que empossasse em vinte e quatro horas o suplente, sob pena de encaminhamento do feito à Procuradoria-Geral da República, para apurar eventuais sanções penais ${ }^{612}$.

A título de curiosidade, apresenta-se também o resultado de dois julgamentos notórios. Em primeiro lugar, o da Deputada Federal Jusmari Oliveira, cujo mandato havia sido pleiteado pelo então PFL no MS 26.604/07, no qual o STF remeteu o caso ao TSE para avaliação de justa causa para troca de legenda. A decisão do TSE veio em 19 de fevereiro de 2008 e declarou a improcedência do pedido do DEM, pois restou comprovado que a Deputada havia solicitado seu desligamento dos quadros do partido por duas vezes: a primeira em 28 de fevereiro de 2007 (antes da data limite) e a segunda em 29 de março de 2007. A tempestividade do requerimento livrou a parlamentar da perda do cargo $^{613}$. O segundo caso é do finado Deputado Clodovil Hernandes, que conseguiu comprovar justa causa para abandonar o PTC e migrar para o $\mathrm{PR}^{614}$.

Dos casos em comento, percebem-se a resistência, a protelação e a subjetividade das “justas causas” alegadas, fatores que marcaram os processos de avaliação

\footnotetext{
${ }^{609}$ O PT, por exemplo, perdeu a Senadora Marina Silva para o PV e o PR perdeu o Senador Flávio Arns para o PSDB. Não há notícias de ingresso na Justiça dos partidos de origem para recuperar as cadeiras.

${ }^{610}$ Cf. TSE, Petição N. 2.778 - Classe 18 ${ }^{\mathrm{a}}$. - MA, rel. Min. Marcelo Ribeiro, 23.04.09, DJE 21.05.09, referente ao processo de justificação do abandono de sigla do Deputado Federal Davi Alves Silva Junior, que por retornar tempestivamente ao partido de origem não teve a perda de seu mandato decretada pelo TSE. Cf. TSE, Petição N. 2.759 - Classe 18 a - DF, rel. Min. Arnaldo Versiani, 10.03.08, DJE 24.04.09, na qual o Deputado Geraldo Resende Pereira teve reconhecida a justa causa para troca de legenda fundada em grave discriminação pessoal.

${ }^{611}$ TSE, Petição N. 2.756 - Classe 18 ${ }^{\mathrm{a}}$ - - DF, rel. Min. José Delgado, 27.03.08, DJE 05.05.08. Ementa: "O requerido não demonstrou grave discriminação pessoal a motivar o ato de desfiliação. Pedido procedente". No dia 18 de dezembro de 2008 a Mesa Diretora da Câmara dos Deputados referendou a decisão.

${ }^{612}$ TSE, Petição N. 2.872 - Classe 24a ${ }^{\mathrm{a}}$ - DF, rel. Min. Carlos Britto, 16.12.08, DJE 01.09.09.

${ }^{613}$ TSE, Petição N. 2.757 - Classe 18 ${ }^{\mathrm{a}}$ - - DF, rel. Min. Ari Pargendler, 19.02.08, DJ 18.03.08.

${ }^{614}$ A partir do depoimento de testemunhas, o TSE julgou comprovada "o abandono e a falta de apoio parlamentar, configurando, portanto, grave discriminação pessoal, apta a ensejar justa causa para a migração partidária." Foi como restou ementada a decisão da Corte Eleitoral. V. TSE, Petição N. 2.766 - Classe 18 ${ }^{\mathrm{a}}$ DF, rel. Min. Arnaldo Versiani, 12.03.09, DJE 29.04.09.
} 
de eventual perda do mandato por ato de infidelidade. São aspectos que desestimulam aos partidos a recuperar as vagas dos trânsfugas, mormente quando diversos acordos políticos são firmados e quando há uma natural movimentação típica do jogo político às vésperas do encerramento do prazo de filiação para as eleições vindouras. Os fatos comprovam que decisões impostas que desconsideram a realidade, obrigando a uma conduta distanciada do procedimento consuetudinário, levam à conhecida situação da "lei de letra morta". 


\section{CONCLUSÃO}

O desafio proposto para o desenvolvimento desta dissertação consistiu em averiguar os reflexos da recente jurisprudência em matéria eleitoral sobre as bases do Estado Democrático de Direito, partindo-se da seguinte questão: as decisões de nossos Tribunais aprimoraram a democracia brasileira de modo a preservar a legitimidade de suas instituições e a unidade do ordenamento jurídico? Ou o hercúleo esforço jurisdicional de moralizar as instâncias políticas pátrias resultou em um agravamento dos problemas longamente vivenciados pela democracia hodierna?

Naturalmente, a resposta a tais indagações não haveria de ser simples e direta. Requereu que inicialmente fossem repassados os elementos fundamentais do Estado Democrático de Direito, as bases da democracia atualmente vivenciada no mundo ocidental, suas condicionantes e seus objetivos, com ênfase na representação política e na democracia pelos partidos. Mas foi a partir da análise detalhada das principais decisões proferidas em temas eleitorais que se buscou extrair os pressupostos para uma fundamentada crítica sobre a atuação das Cortes pátrias, pontuando as implicações decorrentes.

Assim, foram identificadas algumas resultantes do modo de atuação que permitem fundamentar as conclusões deste trabalho. Destacam-se como principais: a inexistência de um padrão da evolução jurisprudencial sobre tais temas, a larga aplicação da hermenêutica constitucional para atingir os resultados almejados e um propalado ativismo judicial.

Ao alternar de forma inconsistente o entendimento sobre determinado assunto, o TSE e o STF criaram, por diversas vezes, situações confusas ao subitamente alterar as regras vigentes sobre a matéria exposta. Configurou-se, deste modo, uma série de atentados ao princípio da segurança jurídica, um dos pilares do Estado Democrático de Direito, que foi amplamente discutido neste estudo. O resultado desse modus operandi é um padrão inconsistente de evolução das decisões judiciais, que, em curto espaço de tempo, adotaram diferentes soluções para casos semelhantes.

Foi o que se pode observar no exame da questão da verticalização das coligações partidárias: a posição do TSE para as eleições de 1998 seria alterada para o pleito seguinte - em 2002. Sofreria nova reviravolta com a atuação parlamentar 
promulgando a EC-52 em 2006, que teve seus efeitos práticos suspensos até as eleições de 2010, por força da aplicação do princípio constitucional da anterioridade eleitoral. Preceito, aliás, que restou desatendido por outra decisão do STF, quando, em abril de 2004, a Corte Suprema resolveu reduzir sensivelmente o quadro de candidaturas nas Câmaras Municipais em pleno ano eleitoral, semeando instabilidade. Novamente, revogando o entendimento jurisprudencial, o Congresso aprovaria Emenda Constitucional em 2009 repondo e incrementando o número de vagas para vereadores. Todavia, seus efeitos seriam obstados por decisão liminar do STF em ADI cujo julgamento ainda se encontra pendente. O reiterado padrão de idas e vindas apenas confirmou que não é possível antever qual situação normativa prevalecerá. Será o STF o último a dar a palavra e regular as condutas sociais ou o Legislativo ainda consegue impor seu principal produto - a lei como espelho da vontade geral?

Os exemplos das decisões sobre a cláusula de barreira e da fidelidade partidária também ilustram a pertinência da indagação. $\mathrm{O}$ primeiro tema, passados três anos da decisão do STF, parece fadado ao esquecimento. Pelo menos até que o Legislativo faça nova tentativa de normatizar a questão e retome a PEC 322, que visa repor a cláusula de barreira em parâmetros mais brandos. Já o tema da fidelidade partidária, como trazido por este estudo, encontra-se em plena efervescência. O Legislativo se movimenta, em seu peculiar ritmo, visando criar a "janela da infidelidade" para permitir as trocas partidárias, por meio de Emenda à Constituição, o que de certa forma, suavizará as sanções por infidelidade e criará diversas válvulas de escape ao parlamentar trânsfuga. $\mathrm{O}$ recente passado confere grandes chances àquele que apostar em uma nova intervenção do Judiciário sobre eventual ação do Legislativo regulando a questão da fidelidade partidária, repetindo a sequência de construção normativa por um Poder e a desconstrução por outro.

Esse indesejável comportamento de ambos os Poderes é reflexo tanto de uma paralisia do Legislativo quanto de um maior ativismo judicial, outro elemento identificado nas conclusões deste estudo e crucial para o deslinde das questões inicialmente colocadas. E que está intimamente ligado ao componente seguinte: o expansivismo hermenêutico. Por meio da interpretação da Constituição e das leis, as Cortes Suprema e Eleitoral parecem ter atingido seus objetivos. $\mathrm{O}$ exame de cada julgamento leva a crer que, em um exercício de plena justificação de suas decisões, os Ministros escolheram os meios adequados para chegar às decisões desejadas. Em outras palavras, a busca de uma constante moralização e aprimoramento ético, tão caros à democracia, parece ter levado os 
Tribunais à necessidade de obter determinados resultados - ou decisões - atendendo aos clamores sociais a qualquer custo. E nisso a interpretação sem limites foi condição sine qua non para se fundamentarem os julgados examinados. Deve-se repetir que o abuso da interpretação apoiada em princípios - ou principiologização da Constituição - leva à criação normativa pura pelas Cortes Judiciais. Em assim procedendo, configurado está um perigoso ativismo judicial, que é um dos mais recentes temas em debate na academia jurídica. E nem poderia ser diferente, pois suas consequências atingem frontalmente os pilares do Estado Democrático de Direito, mormente a harmonia que deve se estabelecer entre os Poderes da nação.

Note-se que não se pretendeu aqui concluir pelo acerto ou erro do mérito das decisões judiciais, porém tecer uma crítica aos meios empregados para suprir o país de medidas tão necessárias para o aprimoramento democrático. As mazelas políticas com que a democracia brasileira convive não serão eliminadas com decisões judiciais pontuais, tampouco com o remendo parlamentar dessas. Sob pena de cansar o leitor, arrisco repetir que está se ministrando remédio para aliviar as consequências e não se combatendo as causas dos problemas que assolam o Estado Democrático de Direito brasileiro. Os sistemas eleitorais, o mau funcionamento dos partidos e sua deficiência ideológica, a cultura política apática do cidadão, a corrupção, a falta de decoro e todas as patologias do sistema político nacional atingem profundamente a democracia. Porém, não há de se colocar como salvadora da pátria a Corte Suprema, resolvendo pontualmente e temporariamente as disfunções que só uma ampla e profunda reforma política poderá corrigir. Cabe sim a sociedade, se ainda não cansada de assistir a esse angustiante filme, movimentar-se no sentido de exigir de suas instituições o adequado emprego das normas constitucionais, cobrando de todos os Três Poderes o efetivo exercício de seus direitos. 


\section{BIBLIOGRAFIA}

AFONSO DA SILVA, José, Curso de direito constitucional positivo, 27ª . ed., São Paulo, Malheiros, 2006.

, Aplicabilidade das normas constitucionais, $5^{\text {a }}$. ed., São Paulo, Malheiros, 2001. , Interpretação da Constituição, in TCM Informativo, São Paulo, n. 27, jun/jul 2005.

AFONSO DA SILVA, Luís Virgílio, Sistemas Eleitorais - Tipos, efeitos jurídico-políticos e aplicação ao caso brasileiro, São Paulo, Malheiros, 1999.

, Interpretação constitucional e sincretismo metodológico, in Luís Virgílio Afonso da Silva (org.), Interpretação constitucional, São Paulo, Malheiros, 2005.

ALEXY, Robert, Epílogos a la teoría de los derechos fundamentales, trad. Carlos Bernal Pulido, Madrid, Centro de Estudios, 2004.

de Estúdios, 2001.

, Teoria de los derechos fundamentales, trad. Ernesto Garzón Valdez, Madrid, Centro

ALMEIDA, Fernanda Dias Menezes de, Competências na Constituição de 1988, $2^{\mathrm{a}}$ ed., São Paulo, Atlas, 2000.

ALMEIDA, Fernando Dias Menezes de, Liberdade de reunião, São Paulo, Max Limonad, 2001.

Considerações sobre a "regulação" no direito positivo brasileiro, in RDPE Revista de Direito Público da Economia, n. 12 (out./dez. 2005).

Assessoria de Comunicação Social do TRE-RO, TRE decreta perda de mandato de Governador e de Senador de Rondônia, 05.11.08, disponível (on line) in www.jusbrasil.com.br/noticias., [10.12.08].

BARROSO, Luís Roberto, Interpretação e aplicação da Constituição, São Paulo, Saraiva, 2007.

, Neoconstitucionalismo e constitucionalização do direito ( $O$ tritunfo tardio do direito constitucional no Brasil), disponível (on line) in www. migalhas.com.br/arquivo_artigo/art04102005.htm.

BASTOS, Celso Ribeiro, Comentários à Constituição do Brasil, vol. 2, Saraiva, São Paulo, 1989.

BISPO SOBRINHO, José, Comentários à lei orgânica dos partidos políticos (Lei N. 9096, de 19 de setembro de 1995), Brasília, Brasília Jurídica, 1996. 
BOULOS, Christiane, Controle preventivo jurisdicional de constitucionalidade - critérios para sua adoção no Brasil, Tese de doutorado defendida na Faculdade de Direito da Universidade de São Paulo, 2006.

BOBBIO, Norberto, O futuro da democracia, trad. Marco Aurélio Nogueira, 10a . ed., Rio de Janeiro, Paz e Terra, 2006.

BONAVIDES, Paulo, Curso de direito constitucional, 10ª edição, São Paulo, Malheiros, 2000. Do Estado Liberal ao Estado Social, 7ª . ed., São Paulo, Malheiros, 2004. O método tópico de interpretação constitucional, Revista de Direito Público, n. 98, abr/jun 1991, p. 5-11.

BRASIL, Constituição Federal da República do Brasil, São Paulo, Saraiva, 2007.

Centro de divulgação da Justiça Eleitoral, disponível (on line) in http://tse.gov.br/sadAdmAgencia., [26.11.09].

CERQUEIRA, Thales Tácito Pontes Luz de Pádua e CERQUEIRA, Camila Medeiros de Albuquerque Pontes Luz de Pádua, Fidelidade partidaria e perda de mandato no brasil: temas complexos, São Paulo, Premier Máxima, 2008.

CLÈVE, Clemerson Merlin, Fidelidade partidária, Curitiba, Juruá, 1998. , Novo regime constitucional dos partidos políticos, Fidelidade partidária, Cadernos de Direito constitucional e Ciência Política, v. 6, n. 24, p. 211-239, jul. /set. 1998.

CRETELLA JUNIOR, José, Liberdades públicas, São Paulo, José Bushatsky Editor, 1974.

DAHL, Robert A., Poliarquia, trad. Celso Mauro Paciornik, São Paulo, EDUSP, 1997.

DALLARI, Dalmo de Abreu, Elementos de teoria geral do estado, 25ª ed., São Paulo, Saraiva, 2005.

DÍAZ GARCÍA, Elías, Estado de derecho y sociedad democrática, in Cuadernos para el Dialogo, Madrid, 2000.

DUVERGER, Maurice, Institutions politiques et droit constitutionnel, 11 éd., Paris, PUF, 1970. Les partis politiques, 3a.ed., Paris, A. Colin, 1958. Os partidos políticos, trad. Cristiano Monteiro Oiticica, Rio de Janeiro, Zahar, 1970. , As modernas tecnodemocracias, trad. Max da Costa Santos, Rio de Janeiro, Paz e Terra, 1975.

DWORKIN, Ronald, Los derechos en serio, trad. Marta Gustaviano, Madrid, Ariel Derecho, 2002. EISENMANN, Charles, $O$ direito administrativo e o princípio da legalidade, RDA N. 56, abr-jun.,1956. 
FERREIRA FILHO, Manoel Gonçalves, Curso de direito constitucional, $34^{a}$ ed., São Paulo, Saraiva, 2008.

, Significação e alcance das "cláusulas pétreas", Cadernos de direito constitucional e ciência política, n. 13, p. 5-10, out./dez. 1995.

, A aplicabilidade das normas constitucionais, in Paulo Lopo Saraiva (coord.), Antologia luso-brasileira de direito constitucional, Brasília, 1992, p. 213-224.

, Estado de direito e constituição, $2^{\mathrm{a}}$ ed., São Paulo, Saraiva, 1999.

, Direitos humanos fundamentais, 9ª.ed., São Paulo, Saraiva, 2007.

, Os partidos políticos nas constituições democráticas, São Paulo, Revista

Brasileira de Estudos Políticos, 1966.

, A democracia no limiar do século XXI, São Paulo, Saraiva, 2006.

, Comentários à Constituição brasileira de 1988, 3ª .ed., Saraiva, São Paulo,

2000.

FERREIRA, Pinto, Manual prático de direito eleitoral, São Paulo, Saraiva, 1973.

, Comentários à Constituição brasileira, 1º vol., São Paulo, Saraiva, 1989.

Folha de São Paulo, Agência Brasil, STF pede informações à Câmara sobre PEC dos Vereadores, São Paulo, 20.12.08, disponível (on line) in http://www1.folha.uol.com.br/ folha/brasil/ult96u481949.shtml., [04.01.09].

Folha de São Paulo, Chinaglia espera que STF barre PEC dos Vereadores, Brasília, 22.12.08, disponível (on line) in http://www1.folha.uol.com.br/folha/brasil/ult96u482248.shtml., [05.01.09].

Folha de São Paulo, Folha on line, TSE define hoje aplicação da cláusula de barreira, São Paulo, 05.10.06, disponível (on line) in www1.folha.uol.com.br/folha/brasil/ ult96u84756.shtml., [05.12.07].

Folha de São Paulo, Mônica Bérgamo, Sarney tira do STF ação para aprovar PEC dos Vereadores, São Paulo, 03.03.09, disponível (on line) in http://www.pslnacional.org.br/ ? $\mathrm{p}=968 .,[10.03 .09]$.

Folha on line, Regra de fidelidade fracassa, e 45 políticos trocam de partido, 02.10.09, disponível (on line) in www.uj.com.br/online/noticias., [04.10.09].

FRIEDRICH, Carl, Gobierno constitucional y democracia, vol. II, Madrid, Instituto de Estudios Politicos, 1975.

FRANCO, Afonso Arinos de Melo, O Constitucionalismo brasileiro na primeira metade do século XIX, in Estudos de direito constitucional, Rio de Janeiro, Forense, 1957. 
G1, Agência Estado, TSE julga viável fusão partidária para superar cláusula, São Paulo, 05.10.06, disponível (on line) in g1.globo.com/Noticias/Politica/0,,AA13005645601,00.html., [05.12.07].

G1, Diego Abreu, Liminar do STF impede posse de beneficiados pela PEC dos Vereadores, Brasília, 02.10.09, disponível (on line) in http://g1.globo.com/Noticias/Politica /0,,MUL1327613-5601,00.html., [09.10.09].

G1, Diego Abreu, TSE suspende julgamento de ação contra Ivo Cassol, 24.11.09, disponível (on line) in www.jusbrasil.com.br/noticias., [26.11.09].

G1, Fausto Carneiro, Primeiro suplente beneficiado pela PEC dos Vereadores já pensa em ser prefeito, Brasília, 28.09.09, disponível (on line) in http://g1.globo.com/Noticias/ Politica/0,,MUL1321540-5601,00.html., [09.10.09].

G1, Justiça anula processo que cassou $1^{\circ}$ mandato por infidelidade partidária, 23.01.08, disponível (on line) in http://g1.globo.com/Noticias/Politica/0,,MUL271049-5601,00justica+ anula+processo +que+cassou+ mandato+por+infidelidade+partidaria.html., [20.07.09].

GALLO, Ronaldo Guimarães, Mutação constitucional, Jus Navigandi, Teresina, ano 7, n. 63, mar. 2003, disponível (on line) in http://jus2.uol.com.br/doutrina/texto.asp?id=3841. [05.05.2009].

GOMES CANOTILHO, José Joaquim, Constituição dirigente e vinculação do legislador: contributo para a compreensão das normas constitucionais programáticas, Reimpressão, Coimbra, Coimbra Editora, 1994.

,Direito constitucional e teoria da Constituição, $4^{\mathrm{a}}$ ed., Coimbra, Livraria Almedina, 2000.

MOREIRA, Vital, Constituição da república portuguesa anotada, $3^{\mathrm{a}}$ ed., Coimbra, Coimbra Editora, 1993.

Estado de Direito, in Cadernos Democráticos - Coleção Fundação Mário Soares, Lisboa, Gradiva, 1999.

,Estado de Direito, in Buscalegis, América do Norte, 029092009.

GRAU, Eros, A ordem econômica na Constituição de 1988, 9ª . ed., São Paulo, Malheiros, 2004.

O direito posto e o direito pressuposto, $7^{\mathrm{a}}$ ed., Malheiros, São Paulo, 2008.

palestra ministrada no XVIII Encontro de Direito Constitucional, promovido pela Associação Brasileira de Constitucionalistas - "Instituto Pimenta Bueno" em 26.09.09 na Faculdade de Direito da Universidade de São Paulo. 
HERMAN SALEM CAGGIANO, Monica, Sistemas eleitorais x representação política, Tese de Doutorado apresentada à Faculdade de Direito da Universidade de São Paulo, São Paulo, 1987.

, Direito parlamentar e direito eleitoral, Barueri, Manole, 2004.

, A fenomenologia dos trânsfugas no cenário político eleitoral brasileiro, in Claudio Lembo (Coord), Monica Hermann Salem Caggiano (Org.), O voto nas Américas, CEPES, 2008.

, A fenomenologia dos trânsfugas. O cenário político-eleitoral brasileiro, disponível (on line) in www.cepes.org.br. , Legislação eleitoral e hermenêutica política x segurança jurídica, Cláudio Lembo (coord.), Barueri, Manole/CEPES, 2006. , A jurisprudência constitucional sobre matéria eleitoral, disponível (on line) in http://www.mackenzie.br/fileadmin/Graduacao/FDir/Artigos_2008/Controle_de consti 2008 processo constitucional_publ mackenzie.pdf.

HESSE, Konrad, A interpretação constitucional, trad. Inocêncio Martirez Coelho in Temas fundamentais do Direito Constitucional, (org). Carlos S. Almeida, Gilmar F. Mendes e Inocêncio M. Coelho, Saraiva, São Paulo, 2009.

HOLANDA FERREIRA, Aurélio Buarque, Novo Dicionário da Língua Portuguesa, $2^{\mathrm{a}}$. ed., Rio de Janeiro, Nova Fronteira, 1986.

IBOPE, Confiança nas instituições, disponível (on line) in www.ibope.com.br., [14.11.09].

KELSEN, Hans, A Democracia, trad. I. Benedetti et alli, São Paulo, Martins Fontes, 2000.

LAFER, Celso, A reconstrução dos direitos humanos, São Paulo, Companhia das Letras, 1991. O moderno e o antigo conceito de liberdade, in Ensaios Sobre a Liberdade, São Paulo, Perspectiva, 1980.

LARENZ, Karl, Metodologia da Ciência do Direito, trad. José Lamego, $3^{\text {a }}$. ed., Lisboa, Fund. Calouste Gulbenkian, 1997.

LIEBHÖLZ, Gerhard, La rappresentazione nella democrazia, Milão, Giufrè, 1989.

LOEWENSTEIN, Karl, Teoría de la Constitución, trad. Alfredo Gallego Anabitarte, Barcelona, Editorial Ariel, 1976.

MACIEL, Eliane Cruxên Barros de Almeida, Fidelidade partidária - um panorama institucional, disponível (on line) in http://www.senado.gov.br/web/cegraf/ril/Pdf/pdf_161/ R161-08.pdf., [24.11.07].

MALBERG, Carré de, Contribution à la Theorie Generale de l'État, vol. II, Sireu, Paris, 1922. 
MEDAUAR, Odete, $O$ Direito Administrativo em evolução, 2a . Ed, São Paulo, Revista dos Tribunais, 2003.

MEIRELLES, Hely Lopes, Direito Municipal Brasileiro, 15ª ed., São Paulo, Malheiros, 2006.

MENDES, Gilmar Ferreira, Direitos fundamentais e controle de constitucionalidade, $2^{\mathrm{a}}$.ed., São Paulo, IBDC, 1999.

O princípio da proporcionalidade na jurisprudência do Supremo Tribunal Federal, novas leituras, Repertório IOB de Jurisprudência, n. 14, caderno 1, jul. 00, p. 371.

, Controle de Constitucionalidade: hermenêutica constitucional de revisão de fatos e prognoses legislativos pelo órgão judicial, in Revista de Direito Constitucional e Internacional, Garcia, Maria (Coord.), N. 31, Ano 8, abr/jun/2000, São Paulo, IBDC.

MEZZAROBA, Orides, Introdução ao Direito Partidário Brasileiro, $2^{\mathrm{a}}$. Ed., Rio de Janeiro, Lumen Juris, 2003.

, A democracia, os partidos políticos e o Estado, in Revista Sequiência n ${ }^{\circ} 43$, Curso de Pós Graduação em Direito - UFSC, dez/2001.

MIRANDA, Jorge, Manual de direito constitucional, v. 4, $3^{\text {a }}$ edição, Coimbra, Coimbra Editora, 1991.

Teoria do Estado e da Constituição, Rio de Janeiro, Forense, 2002.

MONTESQUIEU, Charles, $O$ espírito das leis, $3^{\mathrm{a}}$. ed., trad. Pedro Vieira Mota, São Paulo, Saraiva, 1994.

MORAES, Alexandre de, Direito Constitucional, 23a . ed., São Paulo, Atlas, 2008.

MOREIRA, Vital, Princípio da maioria e princípio da constitucionalidade - legitimidade e limites da justiça constitucional, in Legitimidade e legitimação da Justiça constitucional Colóquio no $10^{\circ}$. Aniversário do Tribunal Constitucional, Coimbra, Coimbra editora, 1995.

NAMAN RIZEK JUNIOR, Rubens, Processo de consolidação e organização legislativa, Tese de doutorado defendida na Faculdade de Direito da Universidade de São Paulo em 2009.

, palestra proferida no XVIII Encontro de Direito Constitucional, promovido pela Associação Brasileira de Constitucionalistas - "Instituto Pimenta Bueno" em 26.09.09 na Faculdade de Direito da Universidade de São Paulo.

NETTO, Menelick de Carvalho, A hermenêutica constitucional sob o paradigma do Estado Democrático de Direito, in Noticia do Direito Brasileiro, N. 6, Universidade de Brasília. 
Notícias STF, Ação Direta de Inconstitucionalidade (ADI) 4307, Brasília, 10.11.09, disponível (on line) in http://www.stf.jus.br/portal/cms/verNoticiaDetalhe.asp?idConteudo=115896., [12.11.09].

O Estado de S. Paulo, Denise Madueño, Chinaglia desafia TSE e diz que não cassará deputado infiel, 17.12.08, disponível (on line) in http://www.estadao.com.br/nacional/not nac295284,0.htm., [21.02.09].

O Estado de São Paulo, Agência Estado, Câmara aprova PEC dos Vereadores, São Paulo, 22.09.09, disponível (on line) in http://www.abril.com.br/noticias/brasil/camara-aprovapec-Vereadores-537416.shtml.,.[29.09.09]

O Estado de São Paulo, Agência Estado, Emenda dos Vereadores provoca crise no Congresso, São Paulo, 19.12.08, p. A10.

O Estado de São Paulo, Agência Estado, PEC não garante posse de perdedor, diz Ayres Britto, São Paulo, 22.09.09, disponível (on line) in http://www.abril.com.br/noticias/brasil/ pec-nao-garante-posse-perdedor-diz-ayres-britto-524924.shtml., [29.09.09].

O Estado de São Paulo, Senado aprova aumento de Vereadores para 59.791 no País, São Paulo, 18.12.08, disponível (on line) in http://www.estadao.com.br/noticias/, [19.12.08].

O Estado de São Paulo, Senado aprova aumento de Vereadores para 59.791 no País, São Paulo, 18.12.08, disponível (on line) in http://www.estadao.com.br/noticias/, [19.12.08].

PASQUINO, Gianfranco, Sistemas políticos comparados, Buenos Aires, Bononiae Libris, 2004.

PEC 124/07, Dep. Wilson Santiago et alli, disponível (on line) in www. camara.gov.br., [01.05.09].

PL 119/07, Deputado Pompeo de Mattos, disponível (on line) in www. camara.gov.br., [01.05.09].

PL 4433/2004, Deputada Denise Frossard, disponível (on line) in www. camara.gov.br., [01.05.09].

PL N. 1.336/07, Deputado Luciano Castro, disponível (on line) in www. camara.gov.br., [01.05.09].

PL N. 1.723/07, Deputado Flavio Dino, disponível (on line) in www. camara.gov.br., [01.05.09].

PL N. 58/07, Deputado Luciano Castro, disponível (on line) in www. camara.gov.br., [01.05.09].

PONTES DE MIRANDA, Francisco Cavalcanti, Comentários à Constituição de 1946, tomo IV, São Paulo, Max Limonad, 1953.RAWLS, John,Uma teoria da justiça, São Paulo, Martins Fontes, 2002.

PORTAL APRENDIZ, Em um ano de fidelidade partidária, 111 são cassados em todo o país, 26.03.08, disponível (on line) in http://aprendiz.uol.com.br/content/neuugogoui.mmp., [20.07.09]. 
Rádio Câmara, Sílvia Mugnatto, Proposta do governo para reforma política traz inovações, 13.02.09, Brasília, disponível (on line) in http://www2.camara.gov.br/internet/radio/ chamadaExterna.html?link= http://www.camara.gov.br/internet/radiocamara/default.asp? selecao=MAT\&Materia=79864., [21.02.09].

RAMOS, Elival da Silva, Parâmetros dogmáticos do ativismo judicial em matéria constitucional, Tese de Titularidade apresentada à Faculdade de Direito da Universidade de São Paulo, 2009.

, palestra proferida no XVIII Encontro de Direito Constitucional, promovido pela Associação Brasileira de Constitucionalistas - "Instituto Pimenta Bueno" em 26.09.09 na Faculdade de Direito da Universidade de São Paulo.

RANULFO MELO, Carlos, Retirando as cadeiras do lugar, Belo Horizonte, UFMG, 2004.

RÉMOND, René, Introduction à l'histoire de notre temps - Le XIX'. siécle - 1815-1914, vol. 2, Éditions Du Suei, s.a.

RESENDE DE BARROS, Sérgio, Aula proferida no curso de pós-graduação da Faculdade de Direito da Universidade de São Paulo, em 15/08/07. , Contribuição dialética para o constitucionalismo, Campinas, Millennium, 2008.

Revista Jus Vigilantibus, Luiz Guilherme Marques, Judiciário x Legislativo?, São Paulo, 13.01.09, disponível (on line) in http://jusvi.com/colunas/37913., [21.02.09].

RIVERO, Jean, Le conseil constitutionnel et les liberté, $2^{\mathrm{e}}$ éd., Paris, Econômica, 1987. , MOUTOUH, Hugues Liberdades públicas, trad. Maria Ermantina de Almeida Prado Galvão, São Paulo, Martins Fontes, 2006.

ROUSSEAU, Jean-Jacques, Do contrato social, trad. Márcio Pugliese e Norberto de Paula Lima, São Paulo, Hemus, s. a.SARTORI, Giovanni, Partidos e sistemas partidários, Waltensir Dutra (trad.), Rio de Janeiro, Zahar, 1982.

SARTORI, Giovanni, Partidos e sistemas partidários, trad. Waltensir Dutra, Rio de Janeiro, Zahar, 1982. , A teoria da representação no estado representativo moderno, trad. E. Gaetani e R. Gaetani, Revista Brasileira de Estudos Políticos, Universidade de Minas Gerais, 1962.

Secretaria Geral da Mesa da Câmara dos Deputados - SGM, disponível (on line) in www2.camara.gov.br., [22.10.09]. 
STARCK, Christian, La légimité de la justice constitutionelle et le principe démocratique de la majorité, in Legitimidade e legitimação da Justiça constitucional - Colóquio no 10. Aniversário do Tribunal Constitucional, Coimbra, Coimbra editora, 1995.

Tribuna da Imprensa On Line, Pesquisa mostra que eleitor é contra a fidelidade partidária, 2003, disponível (on line) in www.tribuna.inf.br/anteriores/2003/marco/07/ noticia.asp?noticia=politica03, [15.10.07].

VERGOTTINI, Giuseppe de, Diritto costituzionale comparato, 2ª ed., Padova, CEDAM, 1987.

VILLALÓN, Pedro Cruz, Legitimidade da justiça constitucional e princípio da maioria, in Legitimidade e legitimação da Justiça constitucional - Colóquio no $10^{\circ}$. Aniversário do Tribunal Constitucional, Coimbra, Coimbra editora, 1995.

\section{Decisões Consultadas}

STF, $1^{a}$. Turma, RE 99.884-5/ES, rel. Min. Oscar Corrêa, 18.10.83, DJ 18.11.83.

STF, ADI N. 3.345/DF, rel. Min. Celso de Mello, 23.08.05, DJ 29.08.05.

STF, ADI N. 3.683/SP, rel. Min. Ricardo Lewandowski, 05.04.06, DJ 20.04.06.

STF, ADI-MC N. 2.346/RJ, rel. Min. Celso de Mello, 15.12.00, DJ 01.02.01.

STF, HC 88.015-MC/DF, rel. Min. Celso de Mello, RTJ 173/805-810.

STF, MS 1.263-AgR/MS, rel. Min. Célio Borja

STF, Pleno, ADI N. 1.351/DF, rel. Min. Marco Aurélio, 07.12.06, DJ 30.03.07;

STF, Pleno, ADI N. 1.710/AL, rel. Min. Sydney Sanches, 03.03.99, DJ 03.09.99;

STF, Pleno, ADI N. 1.805/DF, rel. Min. Néri da Silveira, 26.03.98.

STF, Pleno, ADI N. 1.822/DF, rel. Min. Moreira Alves, 26.06.98, DJ 10.12.99.

STF, Pleno, ADI N. 2.243/DF, rel. Min. Marco Aurélio, 16.08.00, DJ 06.06.03;

STF, Pleno, ADI N. 2.265/RR, rel. Min. Marco Aurélio, 28.09.00, DJ 07.12.00;

STF, Pleno, ADI N. 2.275/PA, rel. Min. Maurício Corrêa, 07.08.02, DJ 13.09.02;

STF, Pleno, ADI N. 2.280/RS, rel. Min. Joaquim Barbosa, 27.09.06, DJ 24.11.06;

STF, Pleno, ADI N. 2.626/DF e N. 2.628/DF, rel. ac. Min. Ellen Gracie, 18.04.02, DJ 05.03.04.

STF, Pleno, ADI N. 221/DF, rel. Min. Moreira Alves, DJ 22.10.93.

STF, Pleno, ADI N. 3.685/DF, rel. Min. Ellen Gracie, 22.03.06, DJ 10.08.06.

STF, Pleno, ADI N. 3.999/DF, rel. Min. Joaquim Barbosa, 12.11.08, DJE 17.04.09.

STF, Pleno, ADI N. 311, Rel. Min. Carlos Velloso, 08.08.1990, DJ 14-09-1990;

STF, Pleno, ADI N. 354, rel. Min. Octavio Galotti, 24.09.90, DJ 22.06.01. 
STF, Pleno, ADI N. 4.086/DF, rel. Min. rel. Min. Joaquim Barbosa, 12.11.08, DJE 17.04.09.

STF, Pleno, ADI N. 536/DF, Rel. Min. Carlos Velloso, 08.08.91, DJ 13.09.91.

STF, Pleno, ADI N. 589/DF, Rel. Min. Carlos Velloso, 20.09.91, DJ 18.10.91.

STF, Pleno, ADI N. 692/GO, rel. Min. Joaquim Barbosa, 02.08.04, DJ 01.10.04.

STF, Pleno, ADI N. 696/DF, rel. Min. Sydney Sanches, 20.09.95, DJ 20.10.95.

STF, Pleno, ADI-MC N. 1.038/TO, rel. Min. Carlos Velloso, 25.03.94, DJ 06.05.94.

STF, Pleno, ADI-MC N. 1.063/DF, rel. Min. Celso de Mello, 18.05.94, DJ 27.04.01.

STF, Pleno, ADI-MC N. 1.347/DF, rel. Min. Celso de Mello, 05.09.95, DJ 01.12.95.

STF, Pleno, ADI-MC N. 1.407/DF, rel. Min. Celso de Mello, 07.03.96, DJ 24.11.00.

STF, Pleno, ADI-MC N. 1.787/PE, rel. Min. Moreira Alves, 26.02.98, DJ 03.04.98.

STF, Pleno, ADI-MC N. 1.900/DF, rel. Min. Moreira Alves, 05.05.99, DJ 25.02.00;

STF, Pleno, ADI-MC N. 147, rel. Min. Carlos Madeira, 24.11.89, DJ 09.02.90.

STF, Pleno, AGRRCL 488/TO, rel. Min. Carlos Velloso, DJ 06.12.96.

STF, Pleno, MI N. 721/DF, rel. Min. Marco Aurélio, 30.08.07, DJE 30.11.07.

STF, Pleno, MS 20.916/DF, rel. Min. Sepúlveda Pertence, 11.10.89, DJ 26.03.93.

STF, Pleno, MS 20.927/DF, rel. Min. Moreira Alves, 11.10.89, DJ 15.04.94.

STF, Pleno, MS 26.602/DF, rel. Min. Eros Grau, 04.10.07, DJE 17.10.08.

STF, Pleno, MS 26.603/DF, rel. Min. Celso de Mello, 04.10.07, DJE 19.12.08.

STF, Pleno, RE N. 197.917, rel. Min. Maurício Corrêa, 06.06.02, DJ 07.05.04.

STF, RE 79.343, rel. Min. Leitão de Abreu, RTJ n. 82, p.791-5.

STF, RMS 21.185/DF, rel. Min. Moreira Alves.

STF, RMS N. 1.945, rel. Min. Sepúlveda Pertence, DJ 11.06.93.

STF, RMS N. 1.949, rel. Min. Marco Aurélio, DJ 17.08.93.

STF, Súmula 625.

STJ, CC 3024/SC, rel. Min. Francisco Peçanha Martins, DJU de 24.05.93).

STJ, S1, Conflito de Competência: CC 88236 SP 2007/0170003-3, rel. Min. Castro Meira, 26.02.08, DJ 17.03.2008.

TSE, ARESPE N. 19.566, rel. Min. Raphael de Barros Monteiro Filho, 18.06.2002, DJ 13.09.02.

TSE, Consulta N. 1.251 e Res. N. 22.213, rel. Min. Carlos Britto, 30.05.06, DJ 20.06.06.

TSE, Consulta N. 1.398/DF e Res. N. 22.526, rel. Min. Celso Asfor Rocha, 27.03.07, DJ 08.05.07.

TSE, Consulta N. 1.407, rel. Min. Carlos Ayres Britto, 16.10.07, DJU de 28.12.07.

TSE, Consulta N. 1.423, rel. Min. José Delgado, 01.08.07, DJU de 28.08.07.

TSE, Consulta N. 346, Res. N. 19.970, rel. ac. Min. Neri da Silveira, 18.09.97, DJ 21.10.97. 
TSE, Consulta N. 358 e Res. N. 20.121, rel. Min. Néri da Silveira, 12.03.98, DJ 16.04.98. TSE, Consulta N. 382 e Res. N. 20.126, rel. Min. Néri da Silveira, 12.03.98, DJ 16.04.98. TSE, Consulta N. 572, Res. N. 20.552, rel. Min. Edson Vidigal, 15.02.00, DJ 24.03.00. TSE, Consulta N. 715/DF e Res. N. 21.002, rel. Min. Garcia Vieira, 26.02.02, DJ 15.03.02. TSE, Consulta N. 841/RJ e Res. N. 21.297, rel. Min. Fernando Neves, 12.11.02, DJ 27.02.03.

TSE, Consulta N. 901/DF e Res. N. 21.474, rel. Min. Fernando Neves, 26.08.03, DJ 03.10.03.

TSE, Consulta N. 926/DF e Res. N. 21.465, rel. Min. Fernando Neves, 19.08.03, DJ 14.10.2003;

TSE, Petição N. 2.756 - Classe 18 . - DF, rel. Min. José Delgado, 27.03.08, DJE 05.05.08.

TSE, Petição N. 2.757 - Classe 18 . - DF, rel. Min. Ari Pargendler, 19.02.08, DJ 18.03.08.

TSE, Petição N. 2.759 - Classe 18 ${ }^{\mathrm{a}}$ - DF, rel. Min. Arnaldo Versiani, 10.03.08, DJE 24.04.09.

TSE, Petição N. 2.766 - Classe 18ª - DF, rel. Min. Arnaldo Versiani, 12.03.09, DJE 29.04.09.

TSE, Petição N. 2.778 - Classe 18ª - MA, rel. Min. Marcelo Ribeiro, 23.04.09, DJE 21.05.09.

TSE, Petição N. 2.872 - Classe 24a . DF, rel. Min. Carlos Britto, 16.12.08, DJE 01.09.09.

TSE, Res. N. 12.871, rel. Min. Torquato Jardim, 29.09.92, DJ 29.09.92

TSE, Res. N. 13.961, rel. Min. Carlos Velloso, 26.10.93, DJ 24.11.93.

TSE, Res. N. 14.139, rel. Min. Carlos Velloso, 07.04.94, DJ 23.05.94.

TSE, Res. N. 14.371, rel. Min. Marco Aurélio, 26.05.94, DJ 30.05.94.

TSE, Res. N. 15.135, rel. Min. Roberto Rosas, 21.03.89, DJ 20.04.89.

TSE, Res. N. 18.083, rel. Min. Sepúlveda Pertence, 28.04.92, DJ 06.05.92.

TSE, Res. N. 18.110, rel. Min. José Celso de Mello Filho, 05.05.92, DJ 01.07.92.

TSE, Res. N. 19.294, rel. Min. Torquato Jardim, 25.04.95, DJ 05.06.95

TSE, Res. N. 19.507, rel. Min. Ilmar Galvão, 16.04.96, DJ 10.05.96.

TSE, Res. N. 19.528, rel. Min. José Bonifácio de Andrada, 23.04.96, DJ 17.05.96.

TSE, Res. N. 19.952 (Consulta N. 327/97-DF), DJ 21.10.97.

TSE, Res. N. 20.114, rel. Min. Neri da Silveira, 10.03.98, DJ 03.06.98.

TSE, Res. N. 20.121 e 20.126, rel. Min. Néri da Silveira, 12.03.98, DJ 16.04.98.

TSE, Res. N. 20.562, rel. Min. José Eduardo Rangel de Alckmin, 02.03.00, DJ 27.03.00.

TSE, Res. N. 20.993, rel. Min. Fernando Neves, 26.02.02, DJ 12.03.02.

TSE, Res. N. 21.297, rel. Min. Fernando Neves, 12.11.02, DJ 27.02.03.

TSE, Res. N. 21.379, rel. Min. Fernando Neves, 15.04.03, DJ 06.06.03.

TSE, Res. N. 21.465, rel. Min. Fernando Neves, 19.08.03, DJ 14.10.2003. 
TSE, Res. N. 21.574, rel. Min. Raphael de Barros Monteiro Filho, 27.11.03, DJ 12.12.03.

TSE, Res. N. 21.608, rel. Min. Fernando Neves, 05.02.04, DJ 09.03.04.

TSE, Res. N. 21.696, rel. Min. Fernando Neves, 30.03.04, DJ 26.04.04.

TSE, Res. N. 21.702, rel. Min. Sepúlveda Pertence, 02.04.04, DJ 06.04.04.

TSE, Res. N. 21.986, rel. Min. Luiz Carlos Madeira, 15.02.05, DJ 30.05.05.

TSE, Res. N. 22.161, rel. Res. Min. Caputo Bastos, 03.03.06, DJ 24.04.06.

TSE, Res. N. 22.610, rel. Min. Cezar Peluso, 25.10.07, DJ 30.10.07.

TSE, Res. N. 22.733, rel. Min. Cezar Peluso, 11.03.08, DJ 27.03.08.

TSE, RESPE N. 32.507, rel. Min. Eros Grau, 17.12.2008, DJ 17.12.08.

TSE, RESPE N. 32.539, rel. ac. Min. Carlos Britto, 17.12.08, DJ 17.12.08.

TSE, RESPE N. 35.741, rel. Min. Marcelo Ribeiro, 22.10.09, DJ 18.11.09.

TSE, RESPE N. 35.906, pendente de julgamento, disponível (on line) in: http://agencia.tse.gov.br [20.11.09]. 


\section{RESUMO}

A sociedade brasileira aguarda pacientemente e há anos uma real reforma que introduza a ética e a moral no meio político e faça valer a soberania de seu povo. De um lado, observa-se um Poder Legislativo com sérias dificuldades de quebrar sua inércia e cumprir o seu papel de concretizar a lei como expressão da vontade geral. De outro, um Poder Judiciário que busca suprir os anseios sociais dando efetividade aos direitos fundamentais colocados na Constituição Federal da República Brasileira de 1988. O presente estudo almeja analisar como o Estado brasileiro tem convivido com um intenso ativismo judicial ou judicialização da política e suas consequências para a democracia pátria. Para a eficácia de suas conclusões, limitou-se o campo de estudo à matéria eleitoral, dada sua cristalina correlação com o Estado Democrático de Direito. Foram selecionadas, deste modo, as recentes decisões dos Tribunais nacionais em temas eleitorais para averiguar os reflexos desta jurisprudência sobre as bases democráticas de nosso país. E, em assim procedendo, foram trazidos elementos para uma crítica fundamentada à tentativa do Poder Judiciário de moralizar as instituições políticas, buscando fornecer as bases para concluir se esse altivo movimento dos Tribunais logrou, de fato, o aprimoramento do regime democrático vigente, preservando a harmonia entre os Poderes, a unidade do ordenamento jurídico e a legitimidade das instituições da nação ou se, ao contrário, apenas soluções pontuais foram conquistadas, combatendo-se uma doença grave com remédios paliativos ao invés de atacar a real causa das mazelas que assolam o Estado Democrático de Direito brasileiro. 


\section{Abstract}

The Brazilian society waits patiently and for many years for a deep change that introduces ethics and moral to politics to renew the sovereignty of its people. On one hand, the Parliament presents serious difficulties in moving forward to fulfill its role of materializing the law as an expression of the general will. On the other hand, the judiciary tries to meet social expectations, providing effectiveness to basic rights constitutionally established. This study aims to analyze how the Brazilian State has been living with an intense judicial activism and a judicialization of its politics and its consequences to democracy. For the effectiveness of its conclusions, the object of the analysis was limited to electoral issue, due to its crystal clear relation with the Rule of Law. In this manner, some recent judicial decisions of the national Courts as regards electoral subjects were chosen to verify the consequences of this jurisprudence on the democratic foundations of our country. And, in so proceeding, many aspects were brought to enable a justified criticism to the judiciary attempt to moralize political institutions, trying to provide the basis for the following questions: have, in fact, this noble movement of the Courts succeeded in improving the current democratic Brazilian system, preserving the harmony between the Powers, the unity of the legal system and the legitimacy of the nation institutions?; or, on the opposite, only few hoc solutions have been conquered, fighting with a serious illness by ministering palliative drugs, instead of solving the real cause of the illness that plagues the State? 